Российский журнал КоГНИТИВНОЙ НАУКИ

\title{
WWW.COGJOURNAL.RU
}

\section{Специальный выпуск}
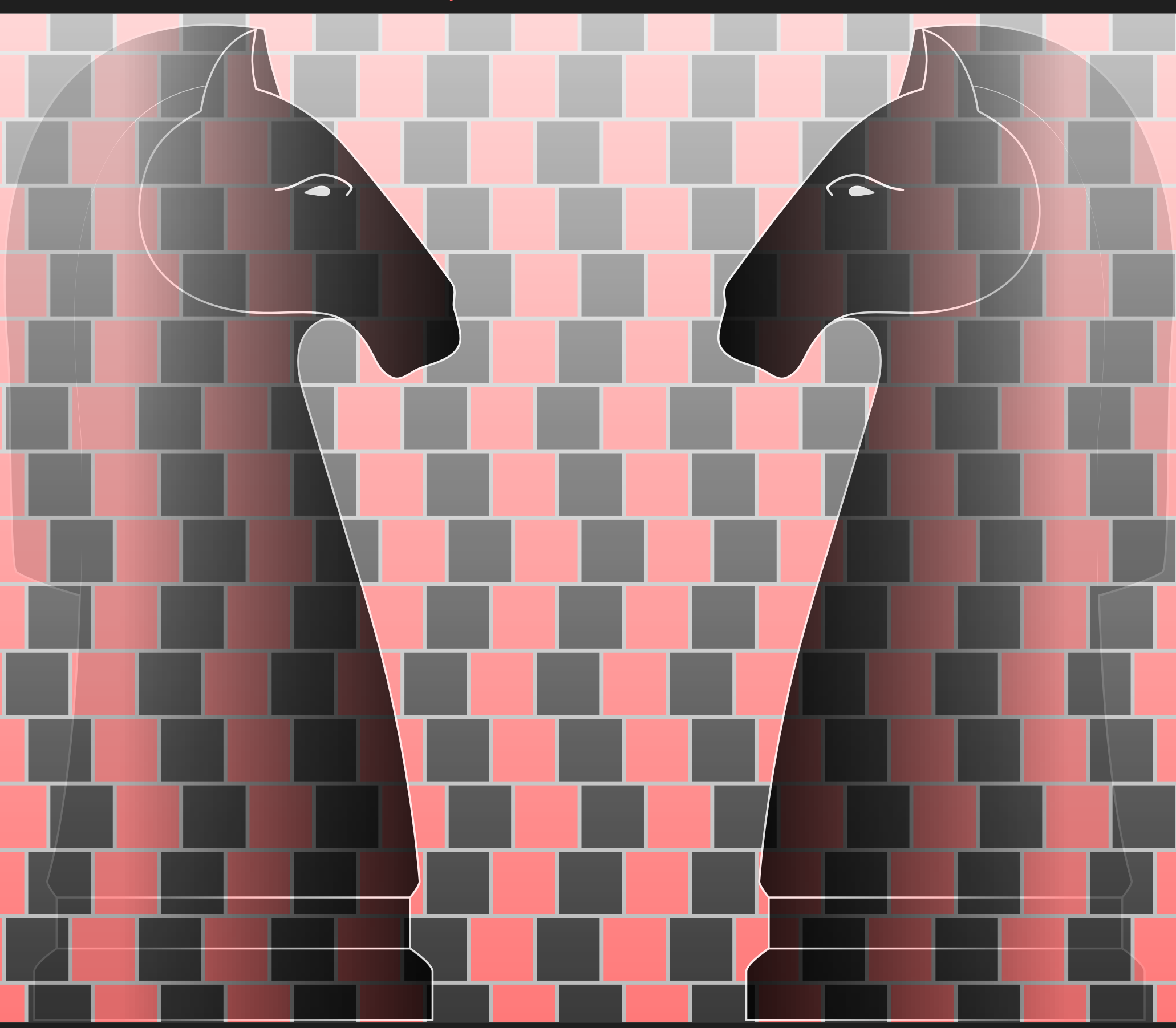

Special Issue

WWW.COGJOURNAL.ORG

Vol. 5

No. 1

March 2018
The Russian Journal of Cognitive Sclence 


\section{The Russian Journal of Cognitive Science}

\author{
http://www.cogjournal.org/
}

ISSN 2313-4518

Russian mass media certificate:

СМИ ЭЛ ФС 77 - 57220

Registered publisher: Ekaterina V. Pechenkova

Editorial office address: Burakova ul. 27,

corp. 3, 105118 Moscow, Russia

e-mail:info@cogjournal.org

Articles are distributed under the terms of the

Creative Commons Attribution License (CC

$\mathrm{BY})$, which permits unrestricted use, distribution, and reproduction in any medium, provided that the original author(s) are credited and that the original publication in this journal is cited, in accordance with accepted academic practice.

Editor-in-Chief: Ekaterina V. Pechenkova

\section{Editorial Board:}

Tatiana V. Akhutina,

Mira B. Bergelson,

Olga V. Dragoy,

Varvara E. Dyakonova,

Maria V. Falikman,

Olga V. Fedorova,

Andrej A. Kibrik,

Andrei V. Kurgansky,

Dmitry V. Lyusin,

Regina I. Machinskaya,

Boris G. Meshcheryakov,

Nadezhda V. Moroshkina,

Vladimir F. Spiridonov,

Igor S. Utochkin,

Anna Yu. Shvarts,

Sergei L. Shishkin,

Nataliya A. Varako,

Roza M. Vlasova

Special Issue on Daniel Everett's

"Don't Sleep, There are Snakes"

Action editor: E.V. Pechenkova

Invited editor: A. D. Koshelev

Managing editor: A.Ya. Koyfman

English copy editor: Kelly Callahan

Russian proofreader: P.G. Lebedeva

\section{Российский журнал когнитивной науки}

\author{
http://www.cogjournal.ru/
}

\author{
ISSN 2313-4518 \\ Свидетельство о государственной \\ регистрации СМИ ЭЛ № ФС 77 - 57220 \\ Учредитель: Е.В. Печенкова \\ Адрес редакции: 105118 Москва, \\ ул. Буракова, д. 27, корп. 3 \\ e-mail: info@cogjournal.org
}

\begin{abstract}
Статьи доступны по лицензии Creative Commons
“Attribution" («Атрибуция») 4.0. всемирная, согласно которой возможно неограниченное распространение и воспроизведение этих статей на любых носителях при условии указания автора и ссылки на исходную публикацию статьи в данном журнале в соответствии с канонами научного цитирования.
\end{abstract}

Главный редактор Е.В. Печенкова

Редакционный совет:
Т.В.Ахутина,
М.Б.Бергельсон,
Н.А.Варако,
Р.М.Власова,
О.В.Драгой,
В.Е.Дьяконова,
А.А.Кибрик,
А.В.Курганский,
Д.В.Люсин,
Р.И.Мачинская,
Б.Г.Мещеряков,
Н.В. Морошкина,
В.Ф.Спиридонов,
И.С.Уточкин,
М.В.Фаликман,
О.В.Федорова,
А.Ю.Шварц,

Специальная тема выпуска:

«Не спи - кругом змеи!» Дэниела Эверетта

Редактор выпуска: Е. В. Печенкова

Приглашенный редактор: А.Д. Кошелев

Секретарь редакции: А.Я. Койфман

Литературный редактор английских

текстов: Келли Кэллахэн

Корректор русских текстов: П.Г. Лебедева

Компьютерная вёрстка: С.М. Злочевский Дизайн обложки: Е.Д. Акопян, А.А. Акопян. 


\section{Contents}

\section{Editorial}

Special Issue: Daniel Everett's “Don't Sleep, There are Snakes” (In Russian) .4

\section{Invited Editorial}

On Relativity of "Exotic" Features of Piraha Language and Principles Underlying Their Worldview (In Russian)

\section{Discussion}

Vladimir M. Alpatov

Why Everett's Book Has Such Influence (In Russian)

Abstract in English

Maxim Krongauz

Daniel Everett and Benjamin Whorf: Linguistic and Non-Linguistic Parallels (In Russian).....

Abstract in English

Svetlana Burlak

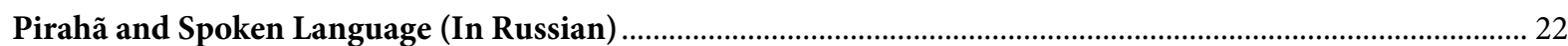

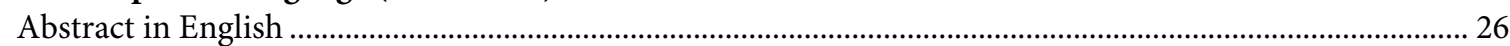

Andrej A. Kibrik

Tyranny of Another Mind (In Russian)

Abstract in English

Valery Solovyev

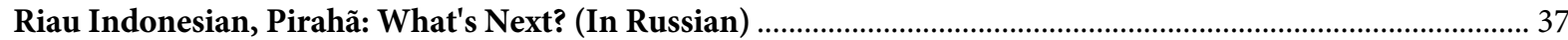

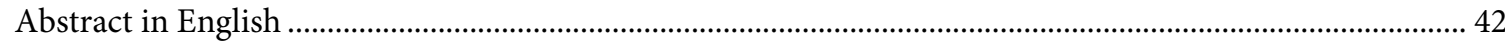

Alexey Koshelev

On The Influence of Culture on Language

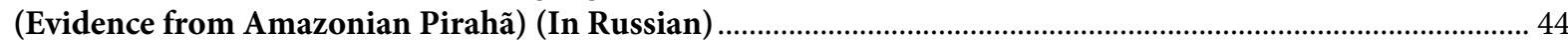

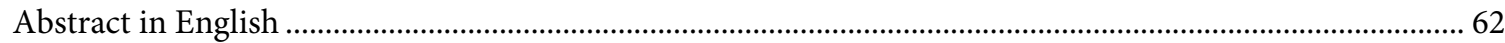

Evgeny Panov

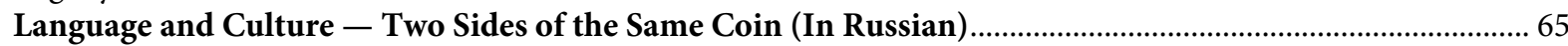

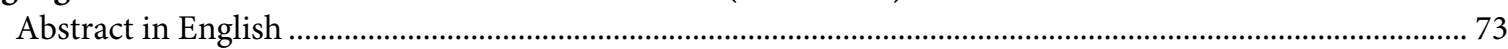

Vadim B. Kasevich

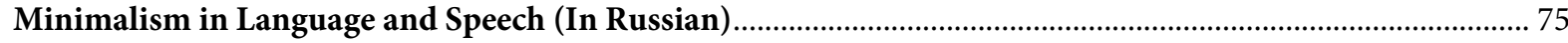

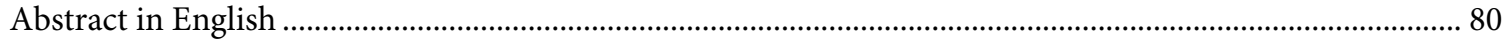

Andrey Nikulin

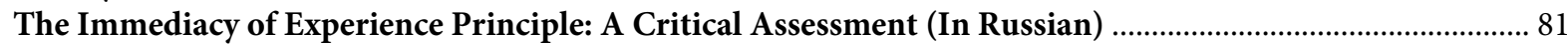

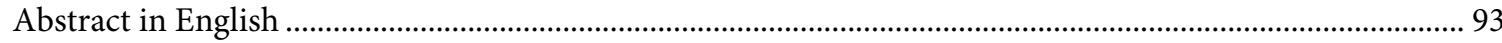




\title{
Оглавление
}

\author{
От редакции
}

Специальная тема выпуска: «Не спи — кругом змеи!» Дэниела Эверетта

\section{От приглашенного редактора}

Об относительности «экзотических» свойств языка индейцев пираха и их принципов восприятия мира

\section{Дискуссия}

Владимир Михайлович Алпатов

Почему у книги Д. Л. Эверетта такой резонанс?

Аннотация статьи на английском языке

Максим Анисимович Кронгауз

Дэниел Эверетт и Бенджамин Уорф: лингвистические и нелингвистические параллели....................... 14

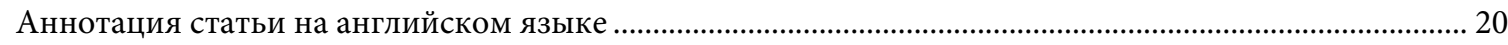

Светлана Анатольевна Бурлак

Язык пираха и разговорная речь

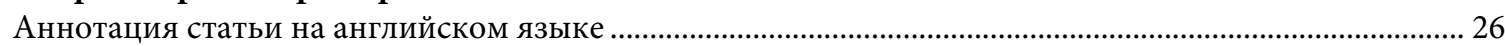

Андрей Александрович Кибрик

Тирания чужого ума

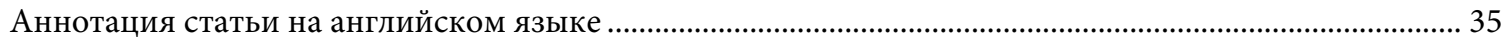

Валерий Дмитриевич Соловьев

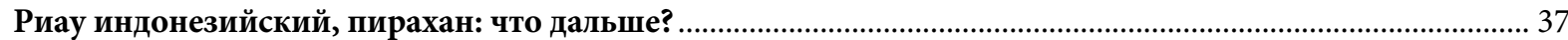

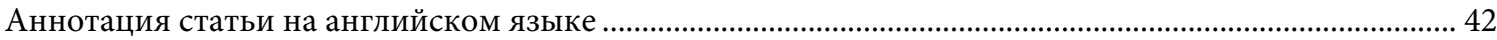

Алексей Дмитриевич Кошелев

О влиянии культуры социума на его язык (на примере амазонского племени пираха) .......................... 44

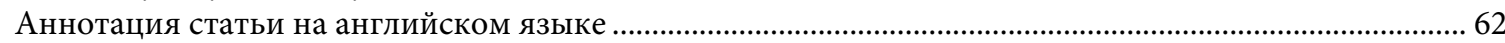

Евгений Николаевич Панов

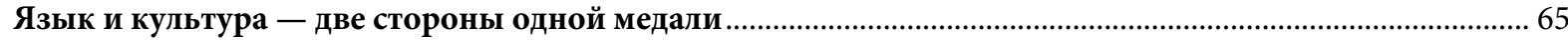

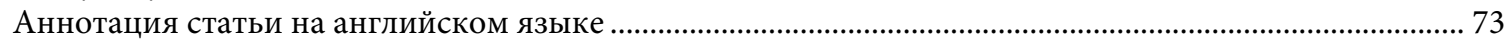

Вадим Борисович Касевич

Минимализм в языке и речи

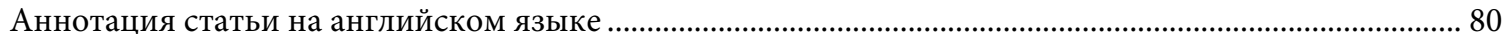

Андрей В. Никулин

Принцип непосредственности восприятия: критическая оценка ............................................................... 81

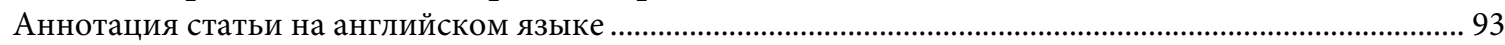




\section{Специальная тема выпуска: «Не спи - кругом змеи!» Дэниела Эверетта}

В основу настоящего спецвыпуска «Российского журнала когнитивной науки» положены доклады участников круглого стола, посвященного выходу в свет перевода на русский язык книги Дэниела Эверетта «Не спи - кругом змеи! Быт и язык индейцев амазонских джунглей»'. Круглый стол состоялся 21 февраля 2017 года в Институте языкознания РАН и был организован при поддержке выпустившего перевод книги издательского дома «ЯСК».

Несмотря на то что на английском языке книга вышла еще в 2008 году2 ${ }^{2}$ она продолжает привлекать к себе читателей во всем мире. На протяжении двух последних десятилетий работы Эверетта активно обсуждались также и в России, в основном в среде профессиональных лингвистов. Теперь, благодаря переводу книги на русский язык, история изысканий Эверетта и описания языка пираха(н) вышла из университетских стен и стала доступна широкому кругу российских читателей.

В русском языке на данный момент устоялись два варианта обозначения языка и одноименного племени амазонских индейцев, которым посвящена книга: «пираха» и «пирахан» (португальское название - pirahã). В переводе книги используется вариант «пираха», тогда как в русскоязычной научной литературе и, в частности, в статьях настоящего выпуска используются оба варианта. Интересное обсуждение этих двух обозначений приводится в статье А. А. Кибрика «Тирания чужого ума».

Дэниел Эверетт посвятил изучению племени пираха более сорока лет. Будучи миссионером, он приступил к освоению необычного языка индейцев с чисто практическими целями, однако через некоторое время основной для Эверетта стала позиция ученого-исследователя. Оказалось, что язык пираха, по-видимому, обладает рядом свойств, существенным образом отличающих его от европейских. Вскоре он вошел в перечень «экзотических» языков, материал которых активно используется в теоретической лингвистике (см. статью В.М. Алпатова «Почему у книги Д. Эверетта такой резо-

\footnotetext{
1 Эверетт Д. Не спи - кругом змеи! Быт и язык индейцев амазонских джунглей / Пер. с англ.: И.В. Мокина, П.С. Дронова, Е.Н. Панова. М.: Издательский дом ЯСК, 2016.

2 Everett D. Don't sleep, there are snakes: Life and language in the Amazonian jungle. New York: Pantheon Books, 2008.
}

нанс?»). Со временем необычность пираха привела Эверетта к мысли, что само существование этого языка опровергает доминирующие в лингвистике представления об универсальной грамматике как общем механизме, лежащем в основе всех человеческих языков. Этот тезис, изложенный не только в книге «Не спи - кругом змеи!», но и в более ранней статье, вышедшей в журнале Current Antropology в 2005 годуз в в свою очередь, спровоцировал обстоятельную дискуссию между Дэниелом Эвереттом и его оппонентами Эндрю Невинсом, Дэвидом Песецки и Силени Родригис на страницах журнала Language в 2009 году (краткий обзор указанной дискуссии приводится в статье А.В. Никулина «Принцип непосредственности восприятия: критическая оценка», см. также статью М.А. Кронгауза в настоящем выпуске).

Дискуссия между Эвереттом и генеративистами (сторонниками Ноама Хомского и его идеи об универсальной грамматике) из чисто научного русла достаточно быстро перекинулась в публичное пространство. Эверетта обвиняли в непрофессионализме, неаккуратном обращении с данными (и даже намекали на их подделку), называли шарлатаном и расистом. Все эти обвинения в конечном итоге привели к официальному запрету со стороны бразильского правительства на проведение дальнейших экспедиций в район проживания пираха сначала для самого исследователя, а затем и для стремившейся собрать независимые данные для проверки его выводов группы Эдварда Гибсона из Массачусетского технологического института (MIT) 4 .

Однако, как показывает в своей статье «Тирания чужого ума» А.А. Кибрик, работы Эверетта на самом деле не поддерживают предвзятый подход к доиндустриальным обществам и их языкам, а способствуют его преодолению. С точки зрения А. А. Кибрика, спорные тезисы Эверетта (такие, как утверждение об отсутствии в языке пираха рекурсии или дизъюнкции) связаны как раз с недостаточно последовательным отходом от европоцентризма,

\footnotetext{
${ }^{3}$ Everett D.L. Cultural constraints on grammar and cognition in Pirahã: Another look at the design features of human language // Current Anthropology. 2005. Vol.46. No. 4. P. 621-646.

4 См. Bartlett T. Angry words // Chronicle of Higher Education, Vol.3, No. 20. URL: https://www.chronicle.com/article/angry-words/131260.
} 
а многие описанные им явления естественны «для большинства нормальных человеческих обществ, сформировавшихся вне письменной традиции, индустриализации и глобализации» (с. 34).

Книга «Не спи - кругом змеи!» - это не просто продолжение ранних научных работ Дэниела Эверетта. Как было отмечено многими участниками круглого стола, это в первую очередь своеобразная книга-автобиография, «путевые заметки», дневник путешественника-первопроходца. Подробный анализ сложной научной биографии Эверетта и ее явного сходства с научной биографией Бенджамина Уорфа приведен в статье М.А. Кронгауза «Дэниел Эверетт и Бенджамин Уорф: лингвистические и нелингвистические параллели». Поэтому не кажется удивительным, что воскрешение старого спора вокруг работ Уорфа и гипотезы лингвистической относительности также во многом обусловлено работами Эверетта. Отталкиваясь от своих наблюдений за пираха, Эверетт приходит не только к рассуждениям в духе Уорфа о том, насколько язык может определять мышление (или наоборот), но и к более радикальной гипотезе, что не только лексическая сторона, но и прочие аспекты языка определяются культурой говорящего на этом языке социума.

Анализу этой гипотезы посвящены две статьи, вошедшие в настоящий выпуск. В статье «Язык и культура - две стороны одной медали» Е.Н. Панов производит критический разбор описания культуры пираха, сделанного Д. Эвереттом, и пытается продемонстрировать читателю, как более тщательный этнографический анализ архаических культур приводит к иному пониманию культуры. Если культура перестает сводиться главным образом к культуре материальной, то тем самым оказывается невозможным рассмотрение языка и культуры как двух взаимодействующих сущностей, одна из которых первична по отношению к другой.

В то же время А.Д. Кошелев в своей статье «О влиянии культуры социума на его язык (на примере амазонского племени пираха)» пытается показать, что реальной движущей силой развития как языка, так и мышления выступает деятельность человека. Хотя это предположение уже фигурировало ранее в рамках дискуссии вокруг гипотезы лингвистической относительности, оно удивительным образом не получило разработки и ранее практически не привлекало к себе внимания лингвистов и философов. Само предположение о том, что связь двух переменных, включенных в гипотезу лингвистической относительности, - языка и мышления - отражает главным образом их совместное изменение под влиянием третьей переменной - деятельности, широко использовалось приверженцами деятельностного подхода в психологии в учебных курсах на факультете психологии МГУ им. М.В. Ломоносова. В качестве свидетельств в пользу этой идеи рассматривались эксперименты Джона Кэррола и Джозефа Касагранде в рамках проекта «Southwest Project in Comparative Psycholinguistics» $\mathbf{5}$, обсуждавшиеся Май-

5 Carroll J. B., Casagrande J. B. The function of language classification in behavior // Readings in social psychology. New York: Henry Holt, 1958. P. 18-31. клом Коулом и Сильвией Скрибнер в книге «Культура и мышление» ${ }^{6}$, а также Дэном Слобином и Джудит Грин в книге «Психолингвистика» (обе книги выходили на русском языке). Тем не менее указанная идея детально не прорабатывалась и оказалась практически не зафиксирована даже в отечественной психологической литературе (см. учебное пособие «Психология мышления» В.В. Петухова в качестве исключения $)$. Поэтому особенно интересен тот факт, что А.Д. Кошелев приходит к идее первичности деятельности по отношению к языку и мышлению совершенно независимо от психологов и на основе анализа совершенно иного материала. Отталкиваясь от этого тезиса, он демонстрирует, как особенности языка племени пираха могут быть выведены из особенностей их деятельности и как эти особенности могут потенциально элиминироваться при изменении их образа жизни.

Согласно гипотезе самого Д. Эверетта, специфика языка пираха объясняется определенной особенностью их культуры: люди из этого племени не говорят о том, что находится за пределами непосредственно переживаемого человеком опыта («принцип непосредственности восприятия»). Подробному критическому анализу этой идеи и возможностей ее эмпирической проверки посвящена статья А. В. Никулина «Принцип непосредственности восприятия: критическая оценка».

В статье «Минимализм в языке и речи» В.Б. Касевич предлагает другой принцип, который мог бы объяснить отсутствие многих языковых явлений в описанном Эвереттом языке: он называет его «принципом тяготения к минимализму». Автор выдвигает предположение, что пираха представляет собой крайне простой язык, использующий минимум средств, необходимых для передачи информации, и что существует когнитивный механизм, который в процессе формирования каждого конкретного языка «выбирает» наименее «затратную» систему средств, обеспечивающую оптимальный коммуникативный результат.

Еще одна альтернативная лингвистическая гипотеза о возможной причине возникновения экзотических свойств языка пираха рассматривается в статье С.А. Бурлак «Язык пираха и разговорная речь». Автор статьи предполагает, что при описании пираха Эверетт мог в недостаточной степени учесть тот факт, что этот язык является бесписьменным, а записанные исследователем высказывания носили разговорно-бытовой характер (на это же обстоятельство указывает в своей статье и А.А. Кибрик). С.А. Бурлак далее демонстрирует, что особенности, отмеченные у пираха, характерны для разговорной речи в целом. К числу таких особенностей разговорно-бытовой устной речи относится и редкое использование синтаксически оформленного подчинения, которое Эверетт отождествляет с синтаксической рекурсией. На это последнее обстоятельство обращает внимание

\footnotetext{
6 Коул М., Скрибнер С. Культура и мышление / Перевод с английского П. Тульвисте. М.: Прогресс, 1977.

7 Слобин Д., Грин Дж. Психолингвистика / Перевод с английского Е.И. Негневицкой. М.: Прогресс, 1976.

8 Петухов В.В. Психология мышления. М.: МГУ, 1987.
} 
В.Д. Соловьев, который в своей статье «Риау индонезийский, пирахан: что дальше?» с точки зрения математика указывает на возможность существования в языке функциональных эквивалентов синтаксической рекурсии и приводит соответствующие примеры.

Нам представляется, что, помимо вклада в обсуждение исследований Д. Эверетта и подлинной или мнимой уникальности языка пираха, идеи, высказанные в рамках круглого стола и более детально разработан- ные авторами в статьях данного спецвыпуска, имеют самостоятельную ценность как для осмысления уже имеющихся фактов, так и для будущих психолингвистических и типологических исследований. Мы надеемся, что, так же как и ставшая отправной точкой для этой дискуссии книга «Не спи - кругом змеи!», они не оставят читателей равнодушными.

Екатерина Печенкова, главный редактор «Российского журнала когнитивной науки» 


\section{от приглашенного редактора}

\section{Об относительности}

\section{«экзотических» свойств}

языка индейцев пираха

и их принципов

восприятия мира

Дэниел Эверетт - профессиональный лингвист с многолетним стажем университетского преподавания ${ }^{\mathbf{1}}$. Его книга «Не спи - кругом змеи! Быт и язык индейцев амазонских джунглей» $(2008 / 2016)^{2}$, несмотря на научно-популярную форму изложения, представляет собой мультидисциплинарное исследование амазонского племени пираха(н) (Pirahã) - его культуры, мышления, языка и быта в их тесном влиянии друг на друга. Изложенная в книге концепция обладает, на наш взгляд, по меньшей мере одним несомненным достоинством: она отражает системный взгляд на племя пираха, соединяющий различные стороны его жизни, не получавшие ранее столь целостного описания.

Для обсуждения этой оригинальной, хотя и далеко не бесспорной концепции в рамках данного спецвыпуска РЖКН мы пригласили ученых разных специальностей: лингвистов, биологов, математиков. В их статьях даются весьма различные оценки выводам Эверетта. Тем не менее мы надеемся, что возникший междисциплинарный диалог поможет читателю сориентироваться в лабиринте различных точек зрения и сформировать собственный взгляд на обсуждаемые проблемы.

В данном предисловии мы не пытаемся поддержать или оспорить те или иные положения концепции Эверетта - это делается в статье (Кошелев, 2018) в настоящем выпуске. Здесь мы хотели бы высказать некоторую общую точку зрения на понятие «экзотическое/уникальное свойство» языка, а именно: показать его относительность. Материалом для конкретных рассуждений нам будут служить концепция Д. Эверетта, язык пираха и статьи данного выпуска.

\footnotetext{
1 С 2010 года он является деканом искусств и наук в университете Бентли, штат Массачусетс. До этого заведовал кафедрой языков, литературы и культур в университете штата Иллинойс. Он также преподавал в Манчестерском университете и заведовал кафедрой лингвистического факультета университета Питтсбурга.

2 Everett D. Don't sleep, there are snakes: Life and language in the Amazonian jungle. New York: Pantheon Books, 2008; Эверетт Д. Не спи кругом змеи! Быт и язык индейцев амазонских джунглей / Пер. с англ.: И.В. Мокина, П.С. Дронова, Е.Н. Панова. М.: ЯСК, 2016.
}

Одно из центральных положений концепции Эверетта заключается в утверждении, что культура социума и его специфическое восприятие мира весьма существенно влияют на его язык. Анализируя быт и культуру индейцев пираха, Эверетт приходит к выводу, что им свойственен принцип непосредственности восприятия (ПНВ). В соответствии с ПНВ одним из главных источников достоверного знания для индейцев являются непосредственные наблюдения (шире личный опыт). Поэтому практически все их интересы и все внимание фокусируются на том, что происходит «здесь и сейчас», ср.: «Пираха просто концентрируются на том, что непосредственно их окружает... Им не нужна истина как некая извечная реальность. $<\ldots>$ Истина для них - это поймать рыбу, грести в лодке, смеяться вместе с детьми, любить своего брата, умереть от малярии» (Эверетт, 2016, с. 295).

Согласно Эверетту, ПНВ препятствует формированию у индейцев отвлеченных и абстрактных понятий, не имеющих непосредственно воспринимаемой составляющей. Поэтому в их языке отсутствуют многие единицы, присущие европейским языкам ${ }^{3}$, такие как цветообозначающие слова (зеленьй, красньй), относительные темпоральные показатели (утро, вечер, завтра), точные счетные слова (два, три, четыре и т.д.), страдательный залог, рекурсия и др. Рассмотрим эти примеры более подробно.

Анализируя цветообозначения в языке пираха, Эверетт отмечает: «Они не обозначают видимый цвет отдельными словами, которые жестко привязаны к определенным обобщенным представлениям о цвете. Они описывают цвет целыми фразами. <..> их перевод такой: „кровь грязная“ - черный... „оно как кровь“ - красный; „оно незрелое“ - зеленый» (Эверетт, 2016, с. 132).

Эти непосредственные, или аналоговые, описания, содержащие отсылки к общеизвестным предметам

\footnotetext{
3 Или, более точно, «языкам среднеевропейского стандарта» (Standard Average European или $S A E)$. Это понятие, введенное в 1939 году Б. Уорфом, включает практически все европейские языки.
} 
с характерным цветом, - продукты ПНВ, - Эверетт противопоставляет условным монолексическим обозначениям (зеленьци, красныц $)$, характерным для европейских языков.

Сходная ситуация, по мнению Эверетта, имеет место и с лексическими показателями времени. Как он отмечает, в языке пираха нет коррелятов относительных темпоральных показателей: вчера, сегодня, завтра, утро, вечер, неделя, месяи и подоб. В то же время в этом языке имеются другие показатели времени, по своей наглядности вполне соответствующие аналоговым цветообозначениям пираха: hisóogiái «полдень ('солнце большое/сильное)», hibigíbagá’áiso «закат/восход», 'ahoakohoaihio "раннее утро ('перед восходом')» (Everett, 2005, p. 631)4. Все они суть абсолютные характеристики периодов времени, доступные прямому распознаванию по внешним признакам.

Следуя этой логике, можно невольно сделать вывод, что индейцам пираха присущ только принцип непосредственности восприятия, а носителям европейских языков, напротив, свойственен альтернативный принцип опосредованности восприятия. Легко показать, что этот вывод не соответствует действительности. В самом деле, в европейских языках имеются не только условные обозначения цвета: красныци, зеленыц (red, green), но и аналоговые именования, отсылающие к известным предметам с характерным цветом: аметистовый (amethyst), бронзовый (bronze), морковный (carrot), каштановыц (chestnut), янтарный (amber). Точно так же в этих языках присутствуют как слова, называющие относительные периоды времени, не имеющие прямых визуальных маркеров: ympo (morning), вечер (evening), завтра (tomorrow), так и абсолютные показатели: восход, закат, полдень (sunrise, sunset, midday), называющие визуально идентифицируемые периоды времени. Таким образом, носителям европейских языков присущи оба принципа восприятия - непосредственности и опосредованности.

Это же верно и в отношении индейцев пираха. Ниже, в статье (Кошелев, 2018, настоящий выпуск), мы показываем, что принцип непосредственности восприятия отражает синкретизм (недифференцированность) ментальных представлений человека, а принцип опосредованности восприятия - системность этих представлений. Цветовой и временной спектры действительности отражаются в сознании индейцев пираха синкретичными ментальными репрезентациями, поэтому отсылки к фрагментам этих представлений невозможны без опоры на непосредственно идентифицируемый маркер («красный» - «оно как кровь», «полдень» - «солнце большое/сильное»). Но в мире индейцев пираха есть также сферы действительности, ментальным представлениям которых присуща весьма детализированная системность, в то время как у носителей европейских языков эти сферы представляются в сознании гораздо менее системными репрезентациями.

Например, в практической жизни индейцев огромную роль играют джунгли. Они знают множе-

\footnotetext{
4 Everett D. Cultural constraints on grammar and cognition in Pirahã: Another look at the design features of human language // Current Anthropology. 2005. Vol. 46. No. 4. P. 621-646.
}

ство видов деревьев и трав, их лечебные и другие свойства, а также приемы их обработки и использования. По-видимому, в этой сфере ментальные представления действительности у индейцев гораздо более дифференцированы и системны, чем у членов индустриальных обществ. Поэтому в языке пираха имеется обширный класс конкретной лексики, обозначающей эти растения, их свойства и действия с ними. А это, как мы показываем (там же) есть следствие системного принципа восприятия мира джунглей. Аналогичную роль играют для индейцев рыбная ловля, плавание в лодке и все, что связано с миром реки. Поэтому и здесь их восприятие более детализировано, чем восприятие рядового носителя европейского языка. Приведем два эпизода из книги Эверетта, иллюстрирующих способность индейцев пираха видеть в окружающем их мире важные детали явлений, совершенно ускользающие от взгляда самого Эверетта.

В первом эпизоде Эверетт рассказывает, как он со старшей дочерью Шеннон отправился с индейцами в лодке охотиться на анаконду.

«Кохои с Поиои бесшумно подгребли к правому берегу... Кохои повернулся к нам с Шеннон и спросил: - Видите ее нору - вон там, едва под водой? - Нет, - ответили мы. Я не видел решительно ничего. - Смотри! - сказал он, взял лук высотой с человеческий рост, какие делают пираха, и потыкал им в воду несколько секунд. Сейчас взъярится. - И он хихикнул. - Видишь? - Нет, - ответил я. Мы с Шеннон ничего не видели в воде, взбаламученной дождями. - Смотри, ил! - воскликнул Кохои. - Вылезает! Тут я увидел небольшое завихрение ила под водой, но не успел я и рта раскрыть, а Кохои выпрямился во весь рост и натянул лук. Ффу! Ффу! - две его стрелы сорвались с тетивы и ушли под воду меньше чем за секунду. И тут же из-под воды выметнулась трехметровая анаконда, пронзенная в двух местах длинными стрелами, и забилась в конвульсиях» (Эверетт, 2016, с. 126).

Во втором эпизоде Эверетт идет по лесу с подростком по имени Каиоа (Kaioá).

«Уже было темно, и мы шли из его хижины ко мне домой... по узкой тропинке в джунглях... Каиоа шел чуть позади... Внезапно он... тихо произнес: - Смотри, там впереди кайман! Я направил на тропинку луч фонаря, но ничего не увидел. - Выключи эту молниеподобную штуковину в руке, - предложил Каиоа, - и посмотри в темноту. Я послушался. Теперь не было видно вообще ничего. - О чем ты говоришь? - спросил я, подозревая, что он хочет меня разыграть. - Там ничего нет. - Нет же. Смотри! - Каиоа хихикнул. Моя неспособность видеть дальше своего носа была для пираха источником нескончаемого веселья. - Видишь вон там такие два глаза, похожие на кровь?

Я напряг глаза и, конечно, разглядел две красных точки метрах в тридцати от нас. Каиоа 
сказал, что это глаза некрупного каймана» (Эверетт, 2016, с. 268).

Продолжим анализ. Отмечая отсутствие числительных в языке пираха, Эверетт пишет:

«Сначала я думал, что в языке пираха есть слова „один“, „два“ и „много“, что не редкость среди языков мира. Но потом я понял, что те слова, которые я и предыдущие исследователи принимали за числительные, означают только относительно большее или меньшее количество» (Эверетт, 2016, c. 129).

Тем самым, в отличие от европейских языков с их счетными словами, называющими точные количества, в языке пираха имеются лишь имена приближенных количеств: hói 'небольшое количество', hoí 'большое количество', xogió 'всё или почти всё' и др. Но и в европейских языках присутствуют слова и выражения, обозначающие неточные количества. Например, как отмечается в статье (Бурлак, 2018, настоящий выпуск), в русском языке слово пара обозначает 'некоторое небольшое количество’. Так, на просьбу дать пару спичек мы можем получить три и даже пять спичек. Кроме того, есть специальное счетное слово несколько, обозначающее приблизительное количество от двух-трех до восьми-десяти.

Подобные рассуждения справедливы и в отношении страдательного залога, отсутствующего в языке пиpaхa, см. об этом в статье (Кошелев, 2018, настоящий выпуск). С особой отчетливостью относительность противопоставлений свойств языка пираха и европейских языков проявляется при анализе наиболее известного утверждения Эверетта об отсутствии в пираха рекурсии, см. (Дронов 2016 5; Никулин, 2018; Соловьев, 2018, настоящий выпуск). С одной стороны, в европейских языках есть сферы, в которых рекурсия практически не используется. Как отмечается в (Бурлак, 2018, настоящий выпуск), «если обратиться не к письменному языку, а к устной, разговорной речи, в особенности к разговорно-бытовому регистру» (с. 23), то можно увидеть почти полную редукцию вложенных конструкций (придаточных предложений, посессивных конструкций и т. п.), см. также (Дронов, 2016). С другой стороны, как показано в целом ряде исследований, см., например (Кибрик, 2018; Никулин, 2018; Соловьев, 2018, настоящий выпуск), некоторые высказывания языка пираха вполне могут трактоваться как рекурсивные.

Аналогичная ситуация имеет место и с фатической коммуникацией, которая, по мнению Эверетта, отсутствует у индейцев пираха, ср.: «У них нет слов „спасибо“, „извини“ и так далее» (Эверетт, 2016, с. 31). Как отмечается в статье (Кибрик, 2018, настоящий выпуск), «вероятно, этот вывод основан на меньшей частотности подобных случаев в коммуникативной практике пираха, однако в книге есть немало примеров, показывающих, что само это явление на самом деле имеет место» (с. 30).

Подведем некоторые итоги. В лингвистической традиции долгое время сохранялась тенденция распространять многие положения, принятые в отношении европейских языков, и в первую очередь английского языка, на остальные языки (лингвистический европоцентризм). Если же какие-то языки не соответствовали этим положениям, их нередко называли экзотическими. Эта тенденция начала меняться на противоположную после появления статьи Э. Даля (Dahl, 1990) ${ }^{6}$ с симптоматичным называнием «Языки среднеевропейского стандарта как экзотические». Важную роль в этом процессе сыграла статья (Evans, Levinson, 2009) ${ }^{7}$, см. также заключение статьи (Кибрик, 2018) в настоящем выпуске. Цель проведенных выше рассуждений - пояснить относительность понятия «экзотическое/уникальное свойство языка», независимую от принятой точки отсчета - той группы языков, которые признаются как носители наиболее общих типологических черт.

Алексей Кошелев, приглашенный редактор спецвыпуска РЖКН, главный редактор издательского дома «ЯСК»

\footnotetext{
5 Дронов П. С. Так ли уж несовместимы точки зрения Д. Эверетта и генеративистов? // Эверетт Д. Не спи - кругом змеи! Быт и язык индейцев амазонских джунглей. Пер. с англ.: И.В. Мокина, П.С. Дронова, Е.Н. Панова. М.: ЯСК, 2016. С. 309-324.

6 Dahl, Ö. Standard Average European as an exotic language // Bechert, Johannes, Giuliano Bernini, \& Claude Buridant (eds.) 1990. Toward a typology of European languages. (Empirical Approaches to Language Typology, 8). Berlin: Mouton: De Gruyter. P. 3-8.

7 Evans N., Levinson S. The myth of language universals: Language diversity and its importance for cognitive science // Behavioral and Brain Sciences, 32(05). Vol.32. P.429-492.
} 


\title{
Почему у книги Д. Л. Эверетта такой резонанс?
}

\section{Владимир Михайлович Алпатов}

Институт языкознания РАН, Москва, Россия

\begin{abstract}
Аннотация. Книга американского исследователя Д.Л. Эверетта вызвала значительный интерес и в США, и в других странах, включая Россию. В ней рассматриваются быт, культура и язык небольшого этноса пираха в Бразилии. Автор отмечает уникальность некоторых явлений пираха, иногда создается впечатление преувеличения особенностей этого языка. Главный объект критики у Д.Л. Эверетта - идеи Н. Хомского. Он считает, что в американской науке полное господство генеративной лингвистики уже в прошлом, а теперь идет обратный процесс - разочарование в ее идеях: говорят, что они стали «слишком расплывчатыми и не поддающимися проверке» и что «языки не так похожи друг на друга, как полагал Хомский». Для Д. Л. Эверетта свойственное Н. Хомскому изучение языка без обращения к культуре неполно. В данной книге отразилась та же тенденция перехода от формальной к функциональной лингвистике, которую мы видим в России. Однако в США она сдерживается влиянием генеративизма.
\end{abstract}

Контактная информация: Владимир Михайлович Алпатов, v-alpatov@ivran.ru; 125009, Москва, Б. Кисловский пер., 1, Институт языкознания РАН.

Ключевые слова: Эверетт, пираха, генеративная лингвистика, язык, культура, антропология, грамматика

(c) 2018 Владимир Михайлович Алпатов. Данная статья доступна по лицензии Creative Commons "Attribution" («Атрибуция») 4.0. всемирная, согласно которой возможно неограниченное распространение и воспроизведение этой статьи на любых носителях при условии указания автора и ссылки на исходную публикацию статьи в данном журнале в соответствии с канонами научного цитирования.

Статья поступила в редакцию 15 марта 2017 г. Принята в пеачть 14 октября 2017 г.

Книга американского исследователя Д.Л. Эверетта «Не спи - кругом змеи! Быт и язык индейцев амазонских джунглей», изданная в 2008 г., а в 2016 г. появившаяся в русском переводе (Эверетт, 2016)', вызвала значительный интерес и в США, и в других странах, включая Россию. Одним из свидетельств этого интереса стал специальный круглый стол, посвященный книге, состоявшийся в феврале 2017 г. в Институте языкознания РАН.

Д.Л. Эверетт рассматривает быт, культуру и язык небольшого этноса пираха в амазонских джунглях (Бразилия). Я буду говорить лишь о лингвистической части книги с позиции историка языкознания.

Почему книга Эверетта вызвала значительный резонанс? Чтобы разобраться в этом, нужно рассмотреть некоторые общие вопросы истории науки о языке.

В этой науке (разумеется, не только в ней) происходят два процесса: открытие новых фактов за счет введения в оборот ранее не изученных языков и за счет более тщательного изучения уже известных языков и создания объяснительных теорий; см. об этом (Бенвенист, 1958/1974). Исследование фактов основано на индукции, создание теорий - на дедукции. При этом постоянно происходят некоторые колебания

\footnotetext{
1 Далее ссылки на русское издание даются в тексте с указанием лишь номеров страниц
}

между хаосом и упорядочением: открытие фактов увеличивает хаос, теории производят упорядочение.

Два примера, которые я уже приводил в статье «Что и как изучает языкознание?» (Алпатов, 2015). В европейской традиции издавна сложилось некоторое представление о звуках языка, но появление экспериментальной фонетики показало, что звуковых различий объективно больше, чем это замечают носители языка; увеличился хаос. Выходом стало создание фонологии, которая произвела упорядочение. Концепция членов предложения сложилась на материале индоевропейских языков, для которых характерно согласование сказуемого с подлежащим - и только с ним. Расширение круга изучаемых языков поставило под сомнение традиционную концепцию в ее пункте, казавшемся главным, - в понятии подлежащего. Хаос временно увеличился. Тогда появились новые объяснения (например, Л. Теньера (1959/1988)), которые произвели упорядочение.

В истории языкознания чередуются периоды сбора фактов и построения теории. Компаративисты после А. Шлейхера сосредоточились на самостоятельном собирании фактов, игнорируя развитие теории. Потом структуралисты ввели многочисленные накопившиеся факты в рамки дедуктивных теорий; эту деятельность ученые традиционного склада оценивали как 
«слабосилие», нежелание заниматься кропотливым анализом конкретного материала. Однако и дескриптивисты после Л. Блумфилда почти целиком ушли в изучение фактов. Как пишет Эверетт, «до Хомского американский лингвист был почти что обязан провести одиндва года среди носителей индейского языка и написать его грамматику. В североамериканской лингвистике это было чуть ли не обрядом посвящения» (с. 274). Однако «сам Хомский не занимался полевыми исследованиями и тем не менее, очевидно, обнаружил в языке больше интересного, чем любой полевой исследователь» (там же). Добавлю, что Н. Хомский всегда принципиально сосредоточен на материале английского языка.

Эверетт интересен в том числе и тем, что это редкий пример лингвиста, совмещающего собирателя фактов и создателя теорий. Еще одним из таких примеров был Э. Сепир, не раз вспоминаемый и высоко оцениваемый в книге. Эверетт подчеркивает, что для него, как и для Сепира, лингвистика - часть антропологии, а не часть психологии, как для Хомского (с. 282).

Книга Эверетта основана на его полевых исследованиях языка пираха. Этот язык теперь входит в ряд знаменитых «экзотических» языков, материал которых широко использовался в теоретической лингвистике. Это австралийский язык аранта, благодаря А. Соммерфельду известный с 1920-х гг., индейский язык США хопи, прославленный Б. Уорфом в 1930-е гг. (Уорф, 1939/1965), язык дирбал (также в Австралии), описанный Р. М.У. Диксоном в 1970-е (Dixon, 1972). Каждый из них сыграл роль в развитии лингвистической теории, однако в связи с ними встал вопрос о достоверности фактов. Перепроверка поставила их под сомнение для аранта и хопи (вымерший вскоре после открытия дирбал, кажется, не успели перепроверить). Не так ли произойдет и с пираха? Однако во всех таких случаях независимо от реальности фактического материала ставятся вопросы, на которые надо уметь отвечать.

Автор книги показывает многочисленные трудности научного и бытового характера, с которыми ему пришлось столкнуться. Среди них первоначальное отсутствие общего языка с информантами и в прямом, и в переносном смысле. Здесь существует методика полевых исследований, разработанная еще дескриптивистами, но, разумеется, сложностей много, и Эверетт пишет: «Все силы, потраченные в тех краях, ушли на борьбу с грамматикой пираха, на попытки разгадать ее» (с. 189). В результате он приходит к выводу: «Объект далек от всего, известного лингвистам» (с. 190).

Какие лингвисты здесь имеются в виду? Как и для большинства его коллег, для Эверетта вся лингвистика - американская наука, иногда с добавлением британской. Один раз упомянута устная консультация немецкого ученого, но ссылок на работы не на английском языке нет. Например, говоря о двойном членении (основополагающая роль которого для языка в книге признается), упомянут лишь «дуализм структуры» Ч. Хоккета (с. 213), хотя переводчик справедливо указывает, что эти идеи восходят к двойному членению А. Мартине (там же). Можно пойти еще дальше: по свидетельству Р. Якобсона, впервые о двойном членении в 1930 г. писал в Ленинграде Д. В. Бубрих (Якобсон 1970/1985).
Что касается уникальности явлений пираха, то Эверетт иногда отмечает сходство отмеченных явлений с другими «экзотическими» языками, иногда нет. Но все же в ряде случаев создается впечатление преувеличения особенности пираха: тоны, бедность именной и богатство глагольной морфологии широко распространены в языках мира. Некоторые свойства пираха вряд ли столь уникальны: ссылаясь на Г. Корбетта, Эверетт полагает, что, исключая пираха, категории числа нет только в некоторых древних языках (с. 210). Но такой категории нет ни в современном китайском языке, ни в айнском языке, а в японском языке ее можно обнаружить лишь у подкласса одушевленных существительных. Правда, не всегда обо всем этом можно судить, так как, например, говоря о сложном устройстве глагола пираха, Эверетт представления о нем не дает, только упоминая о существовании категории эвиденциальности. Не до конца ясен и порядок слов.

Теперь попытаюсь выделить те существенные особенности, которые в книге приписаны языку пираха, и определить, в чем его необычность.

Фонетика - можно выделить, прежде всего, две особенности. Во-первых, необычно велико свободное варьирование в сегментной фонологии (с. 195). Во-вторых, «в языке пираха существуют пять... каналов, каждый из которых выполняет уникальную функцию в культуре этого этноса. Таковы свист, мычание, музыкальная речь, выкрики и, наконец, стандартная речь с использованием согласных и гласных» (с. 199). Их Эверетт называет каналами дискурса. Часть из них встречается и в других языках, но все пять каналов зафиксированы только в пираха. Каналы функционально распределены: каждый из них применяется в специфичной для него культурной ситуации. Всеми каналами, по мнению Эверетта, можно передать любую информацию: «как и любой другой подлинный канал коммуникации, мычащая или мурлыкающая речь способна передать абсолютно все, что можно сказать и с использованием согласных и гласных звуков» (с.200). Последнее утверждение представляется слишком категоричным, а приводимые примеры скорее демонстрируют, что каналы, за исключением «стандартной речи», используются в ситуациях, где передается лишь информация определенного вида.

Лексика - нет числительных (впрочем, Эверетт признает, что пираха могут считать по пальцам), обозначений цвета, кванторов, бедны термины родства, ориентация лишь по направлению к ориентиру - реке, поэтому нет понятий левого и правого (с. 232 - 233).

Морфология - неясно.

Синтаксис - на этих вопросах Эверетт, исходя из традиций американской лингвистики, останавливается наиболее подробно. Главной особенностью языка пираха он считает то, что там нет придаточных предложений, из чего делается вывод о том, что там нет рекурсии, которая в соответствии с первоначальным определением Хомского понимается как «помещение одной единицы внутрь другой, относящейся к тому же типу» (с. 247). Выделены и другие особенности, скорее свидетельствующие о более простом устройстве синтаксиса пираха по сравнению с моделями Хомского. Нет перемещений. Не может быть двух определений к одному 
имени. Нет дизъюнкции. Эверетт даже приходит к выводу о том, что «в грамматике пираха нет синтаксиса» (с. 256), с чем, разумеется, трудно согласиться.

Наконец, нужно сказать об общетеоретических взглядах Эверетта. Он ведет одновременный спор с двумя направлениями в лингвистике, связанными с именами Уорфа и Хомского. Выше их он ставит Сепира, которого называет основателем американской лингвистики (с. 235), что исторически, конечно, неверно, но для Эверетта вся лингвистика США сводится к этим трем именам и именам их последователей. Наука других стран о языке, как упомянуто выше, для него не существует.

Главный объект критики у Эверетта - теория Хомского. Он считает, что в американской науке полное господство генеративной лингвистики уже в прошлом, а теперь идет обратный процесс - разочарование в идеях Хомского: говорят, что генеративная лингвистика «стала слишком расплывчатой и не поддающейся проверке» и что «языки не так похожи друг на друга, как полагал Хомский» (с. 279). С последним он связывает главный пункт расхождений с мэтром. Это вопрос об отношении языка и культуры. Для Эверетта неприемлема традиционная (господствовавшая уже в структурализме) точка зрения, сохраненная у Хомского: они не связаны друг с другом, изучаются раздельно. Однако для Эверетта обращение языка без обращения к культуре неполно.

Связь языка с культурой на разных уровнях выявляется по-разному. В лексике ее существование трудно отрицать, но можно от нее отвлекаться (что в том числе делал и Соссюр). В фонетике же об этом до Эверетта редко вспоминали. Даже самый, пожалуй, активный сторонник ее признания в советской науке 1950-1960-х гг. В.И. Абаев считал, что такую связь необходимо учитывать в семантике и грамматике, но для фонологии приемлем структурный подход, поскольку там господствуют «чистые отношения» (Абаев, 1960/2006). Но Эверетт, пусть где-то, возможно, преувеличивая, демонстрирует, что в пираха «культурно обусловленными могут быть не только значения отдельных слов..., но и сам характер звуков» (с.217). И это необходимо учитывать. Далее указывается, что Хомский «сознательно игнорировал дискурс и связные тексты», поскольку это «экстралингвистические конструкты» (с. 261), изучение которых требует обращения к культурным факторам. По той же причине у него, как и в традиционной лингвистике, исследование не выходит за рамки предложения.

По Хомскому, как замечает Эверетт, во всех языках одна грамматика с ограниченным варьированием параметров (с. 239), хотя в реальности все сложнее. Тут вспоминается один из традиционных пунктов критики теории Хомского, который у Эверетта прямо не формулируется: в этой теории под общей грамматикой часто понимается грамматика английского языка. Во всяком случае, она ориентирована на материал языков, по строю отличных от пираха. Поэтому, в частности у Хомского, как считает Эверетт, преувеличено значение рекурсии.

Эверетт также стремится опровергнуть и другие базовые положения теории Хомского, по его мнению, не подтверждаемые данными языка пираха. Не надо считать грамматику частью генома человека. Грамматика не может быть врожденной. Материал пираха требует теории, которая не рассматривает язык как инстинкт (с. 262).

Автор книги стремится дать культурные объяснения обнаруженным особенностям языка пираха. Отсутствие рекурсии, по его мнению, связано с замкнутостью общества соответствующего народа. Необходимо учитывать принцип непосредственности опыта (говорят лишь о происходящем здесь и сейчас), запрет на абстракции и обобщения (с. $262-263)$. Такие объяснения вызвали критику, в том числе на круглом столе в Москве. Конечно, подобные рассуждения (которых был не чужд и Уорф) нельзя строго доказать, но трудно и опровергнуть. Переход к лингвокультуроведению в современной лингвистике расширяет круг рассматриваемых проблем ценой резкого снижения степени строгости исследования по сравнению с формальной лингвистикой.

Иное отношение в книге к идеям Уорфа: многое в них принимается, в том числе разграничение так называемого среднеевропейского стандарта и связанных с культурой особенностей языков иных ареалов. Но не принимается первичность зависимости: язык $\rightarrow$ культура. Эверетт исходит из иной причинности: культура $\rightarrow$ язык (хотя у Уорфа можно встретить объяснения обоих типов). По Уорфу получается, что пираха не считают, потому что в их языке нет числительных, а реально дело обстоит наоборот (с. 237).

Подводя итог, можно сказать, что в данной книге отразилась та же тенденция перехода от формальной к функциональной лингвистике, которую мы видим в России. Однако в США она сдерживается влиянием генеративизма. Но Эверетт, как мы уже видели, считает это влияние менее значимым, чем раньше. Близкими к себе по идеям учеными он считает Р. ванн Валина, для которого «движущей силой грамматики по большей части является именно значение», и У. Крофта, изучающего «принципы когниции» в языках мира (с. 224 -225). Назревает ли там смена парадигмы, заметная у нас? Время покажет.

\section{Литература}

Абаев В. И. Статьи по теории и истории языкознания / Под ред. В.М. Алпатова. М.: Наука, 2006.

Алпатов В.М. Что и как изучает языкознание? // Вопросы языкознания. 2015. № 3. С. 7-21.

Бенвенист Э. Категории мысли и категории языка // Общая лингвистика / Под ред. Ю.С. Степанова. М.: Прогресс, 1974. C. $104-114$

Теньер Л. Основы структурного синтаксиса / Под ред. В.Г. Гака. М.: Прогресс, 1988.

Уорф Б.Л. Отношение норм поведения и мышления к языку // Звегинцев В.А. История языкознания XIX-XXвв. в очерках и извлечениях. Часть 2. М.: Просвещение, 1965. C. $255-281$.

Эверетт Д. Не спи - кругом змеи. Быт и язык индейцев амазонских джунглей. М.: ЯСК, 2016.

Якобсон $P$. Лингвистика в ее отношении к другим наукам // Якобсон Р. Избранные работы. М.: Прогресс, 1985. C. $369-420$.

Dixon R.M.W. The Dyrbal language of North Queensland. Cambridge: Cambridge University Press, 1972. doi:10.1017/ cbo9781139084987 


\title{
Why Everett's Book Has Such Influence
}

\section{Vladimir M. Alpatov}

Institute of Linguistics RAS, Moscow, Russia

\begin{abstract}
American researcher Daniel Everett's book “Don't Sleep, There are Snakes: Life and Language in the Amazonian Jungle" provoked considerable interest both in the USA and in other countries including Russia. The author researches the lifestyle, culture and language of a small tribe of people in Brazil, the Pirahã. He notes the uniqueness of some phenomena in the Pirahã language. The main object of Everett's criticism is Noam Chomsky's conception of universal grammar. Everett believes that the predominance of generative linguistics is in the past and that the reverse process - disappointment in Chomsky's ideas - is taking place. It is said that Chomsky's ideas became "too vague and untestable" and that "languages are less alike than Chomsky imagined". According to Everett, the study of languages without any attention to culture (Chomsky's perspective) is imperfect. This book reflects the same trend of a transition from formal to functional linguistics that is very appreciable in Russia. In the USA this tendency has been restrained by the influence of generative linguistics.
\end{abstract}

Correspondence: Vladimir M. Alpatov, v-alpatov@ivran.ru, Institute of Linguistics RAS, 1 B. Kislovskij per., 125009 Moscow, Russia

Keywords: Daniel Everett, Pirahã, generative linguistics, language, culture, anthropology, grammar

Copyright ( 9 2018. Vladimir M. Alpatov. This is an open-access article distributed under the terms of the Creative Commons Attribution License (CC BY), which permits unrestricted use, distribution, and reproduction in any medium, provided that the original author is credited and that the original publication in this journal is cited, in accordance with accepted academic practice.

Received March 15, 2017, accepted October 14, 2017.

\section{References}

Abaev, V.I. (2006). Stat'i po teorii $i$ istorii yazykoznaniya [Papers in theory and history of linguistics]. Moscow: Nauka. (In Russian).

Alpatov, V.M. (2015). Chto i kak izuchaet iazykoznanie [Linguistics: what and how?] Voprosy Jazykoznanija (Topics in the study of language), 2015(3), 7-21. (In Russian).

Benveniste, É. (1958). Catégories de pensée et catégories de langue. Les études philosophiques, 13(4), 419-429. (In French).

Dixon, R.M.W. (1972). The Dyrbal language of North Queensland. Cambridge: Cambridge University Press. doi:10.1017/ cbo9781139084987

Everett, D. (2008). Don't sleep, there are snakes: Life and language in the Amazonian jungle. London: Profile Books.
Jakobson, R. (1985). Lingvistika v ee otnoshenii $\mathrm{k}$ drugim naukam [Linguistics in relation to other disciplines]. In Izbrannye raboty [Roman Jakobson. Selected works] (pp.369-420). Moscow: Progress.

Tesnière, L. (1959/1988). Eléments de syntaxe structurale. Paris: Klinksieck. (In French).

Whorf, B.L. (1956). The relation of habital thought and behavior to language. In J. Carroll (Ed.), Language, thought and reality, Selected writings of Benjamin Lee Whorf (pp.134-160). Cambridge, MA: Technology Press of MIT. 


\section{Дэниел Эверетт}

\section{и Бенджамин Уорф:}

лингвистические

\section{и нелингвистические параллели}

\section{Максим Анисимович Кронгауз}

Национальный исследовательский университет «Высшая школа экономики»;

Российский государственный гуманитарный университет, Москва, Россия

Аннотация. Анализируется сходство научных биографий Б. Уорфа, одного из авторов гипотезы лингвистической относительности, и Д. Эверетта, описавшего язык пираха. Речь идет об их научно-социальной роли в современных им научных сообществах и обществе в целом и об их взглядах и достижениях. Анализ позволяет объяснить сходство их научной судьбы, огромный успех их теоретических построений, выходящий за пределы лингвистики, и связанные с этим репутационные потери. Точность их конкретных наблюдений может вызывать сомнения, но это не отменяет ценности дискуссии, которую они спровоцировали. Роль гипотезы лингвистической относительности в науке определяется не ее истинностью, а тем массивом исследований, для которых она стала методологией и одновременно стимулом. Д. Эверетт, возможно, участвует в построении новой ее модификации, а именно комплексном и междисциплинарном изучении языка и культуры в корреляции с нормами поведения и мышления.

Контактная информация: Максим Анисимович Кронгауз, mkronhaus@yandex.ru; 105006 Москва, Старая Басманная ул., д. 21/4, стр. 1, каб. 528; НИУ ВШЭ, факультет гуманитарных наук, школа филологии.

Ключевые слова: Бенджамин Уорф, Дэниел Эверетт, гипотеза лингвистической относительности, хопи, категория времени, пираха, пирахан, рекурсия, универсальная грамматика, Ноам Хомский

(c) 2018 Максим Анисимович Кронгауз. Данная статья доступна по лицензии Creative Commons "Attribution" («Атрибуция») 4.0. всемирная, согласно которой возможно неограниченное распространение и воспроизведение этой статьи на любых носителях при условии указания автора и ссылки на исходную публикацию статьи в данном журнале в соответствии с канонами научного цитирования.

Благодарности. Исследование выполнено при финансовой поддержке РФФИ в рамках научного проекта № 18-012-00712.

Статья поступила в редакцию 16 мая 2017 г. Принята в печать 21 февраля 2018 г.

\section{Споры об описании языка пираха и взглядах Д. Эверетта}

Эта статья написана по мотивам моего доклада «Бенджамин Уорф XXI века» ${ }^{1}$ на круглом столе в Институте языкознания РАН, посвященном выходу перевода книги Дэниела Эверетта (2016) и состоявшемся 21 февраля 2017 года.

Кроме устной дискуссии на круглом столе состоялась еще и письменная на страницах русского издания, включавшая три статьи (Дронов, 2016; Кошелев, 2016; Никулин, 2016), опубликованные в качестве по-

1 Видеоролик выложен на сайте Youtube (Кронгауз, 2017b). слесловий. Вся эта дискуссия показалась мне интересной и содержательной, но нельзя не признать, что она сильно опоздала - более чем на пять лет. Бурная дискуссия о языке пираха ${ }^{2}$ и исследовании Д. Эверетта ведется с момента публикации его статьи (Everett, 2005) и, по-видимому, достигает пика в конце нулевых годов. В 2009 году в журнале Language (vol. 85, no.2) выходит

\footnotetext{
2 По-видимому, более обоснованным, исходя из португальского pirahã, является русское название «пирахан», которое я использовал в проекте «Язык дня» на сайте Арзамас (Кронгауз, 2017а) и в книге (Кронгауз, Пиперски, Сомин, 2018). В 2017 году это название используется как основное и в «Википедии» на русском языке (Пирахан). Однако, исходя из русского перевода книги Д. Эверетта и чтобы не вносить ненужный разнобой, в этой статье я буду называть язык - пираха, - и не склонять его.
} 
наиболее подробная статья о работе Д. Эверетта, резко критикующая его взгляды (Nevins, Pesetsky, Rodrigues, 2009). В этом же номере появляется не менее подробный ответ самого исследователя (Everett, 2009). Годом ранее выходит в свет самая известная книга Д. Эверетта (Everett, 2008), перевод которой мы сейчас обсуждаем, и дискуссия выходит за рамки научного сообщества. Рецензии на нее публикуются в различных изданиях, а споры продолжаются несколько лет: см., например, The Chronicle of the Higher Education, The Gardian, The Telegraph, Time (Anthony, 2008; Bartlett, 2012; Leith, 2012; McCrum, 2012; Suddath, 2008). См. также видеоролик «Piraha Debate» на Youtube (Piraha Debate, 2011). Всплеск публикаций, посвященных пираха и Д. Эверетту в 2008 году, очевидно, связан с выходом его книги, а в $2012-$ с появлением документального фильма «The Grammar of Happiness», снятого по мотивам этой же книги.

В 2009 году в бразильской газете появляется короткая редакционная заметка, посвященная отношению к Д. Эверетту самого известного в мировой истории лингвиста. Ее название красноречиво: «Он превратился в шарлатана» - говорит Хомский» («Ele virou um charlatão», 2009). В самом тексте более полная цитата Ноама Хомского звучит еще резче:

«Он превратился в чистого шарлатана, хотя был хорошим описательным лингвистом. Именно поэтому, насколько я знаю, все серьезные лингвисты, работающие с языками Бразилии, игнорируют его».

Эта негативная оценка преследует Д. Эверетта последующие годы. Так, в статье в The Telegraph (Leith, 2012) после фразы «Он все еще сражается с Хомским» приводится его ответ Н. Хомскому, в частности слова:

«Я никогда не скажу ничего подобного о нем. Я бы сказал, что он исключительно умный человек, который сделал много хорошего, чтобы мысли о языке стали более строгими, но срок годности его идей истек (his ideas have passed their sell-by date)».

А в статье в The Chronicle of the Higher Education (Bartlett, 2012) эта история рассказывается с дополнительными подробностями:

«Хомский точно не сумел подняться над схваткой. Он рассказал бразильской газете, что Эверетт был „шарлатаном“. В документальном фильме об Эверетте Хомский, не утверждая, что верит в это, все же допустил возможность фальсификации Эвереттом результатов. За кулисами он тоже был активным. По словам Песецкого ${ }^{3}$ Хомский попросил его отправить электронное письмо Давиду Папино, профессору философии в Королевском колледже Лондона, написавшему положительный или, по крайней мере, не негативный отзыв на книгу „Не спи - кругом змеи“. В электронном письме выражалось недовольство тем, что Папино неправильно понял рекурсию и поступил некорректно, приняв сторону Эверетта. Папино же полагал, что он ничего подобного не делал. „Для людей, находящихся вне лингвистики,

\footnotetext{
3 Дэвид Песецкий (David Pesetsky) - американский лингвист, ученик и последователь Ноама Хомского, один из авторов упомянутой выше статьи в журнале Language (Nevins, Pesetsky, Rodrigues, 2009).
}

удивительно видеть такой способ защиты ортодоксальных взглядов“, - говорит Папино».

Совершенно очевидно, что сегодня уже нет той остроты научной дискуссии, которую мы видим в упомянутых научных и журналистских статьях. Именно поэтому, чтобы избежать своего рода вторичности и неактуальности, я, по существу, не буду анализировать научные взгляды Дэниела Эверетта. Точнее, сделаю лишь в той степени, в которой это потребуется для проведения определенной аналогии между Дэниелом Эвереттом и Бенджамином Уорфом. Конечно, речь пойдет не непосредственно об этих людях, а об их научно-социальной роли в современных им научных сообществах и обществе в целом и об их взглядах и достижениях. Эта аналогия не кажется мне искусственной и умозрительной, напротив, она позволяет объяснить сходство их научной судьбы, огромный успех их теоретических построений, выходящий за пределы лингвистики, и связанный с ними репутационный крах. Причем речь идет о крахе и личных научных репутаций, и научных взглядов в целом, хотя о крахе, конечно, можно говорить лишь с существенными оговорками. Прежде, чем перейти к намеченному сравнению, необходимо сделать ряд предварительных замечаний, касающихся истории формирования теорий (хотя это слово и не вполне применимо ко взглядам Д. Эверетта) и научных репутаций, а также написания конкретных работ в конкретном историческом контексте.

\section{Предварительные замечания}

О Д. Эверетте сказано уже много. Тем не менее стоит зафиксировать некоторые хорошо известные вехи в его исследовательском пути. Д. Эверетт, став миссионером, вместе с семьей впервые посещает индейцев пираха в 1977 году. В 1983 году он защищает диссертацию на португальском языке, в которой рассматривает язык пираха в рамках порождающей грамматики. В 1991 году на основе диссертации он публикует книгу (Everett, 1991). В 2005 году он пишет статью о языке пираха, в которой отрицаются важные языковые свойства, - некоторые же из них считались обязательными для любого языка (Everett, 2005). В этом же году он разводится с женой, на которой был женат 35 лет. Одной из причин развода стало разочарование Д. Эверетта в вере и религии и объявление об этом жене. Здесь уместна цитата из предисловия к русскому изданию:

«Когда я впервые приехал к пираха, я был двадцатипятилетним миссионером, отцом троих детей. Я искренне верил в Бога и хотел обратить индейцев в свою веру. Вместо этого пираха обратили меня, сделав свободомыслящим атеистом. За это я им глубоко благодарен. Хотя после этого наш брак с Керен распался, я сохраняю доверительные отношения с детьми» (Эверетт, 2016, с. 11).

В 2008 году выходит самая известная книга Д. Эверетта (Everett, 2008), которую едва ли можно отнести к научной или научно-популярной литературе. По жанру она, скорее, относится к запискам путешественника, то есть человека, который, оказавшись 
в экзотическом месте среди неизвестного народа, постепенно знакомится с ним и рассказывает читателю о своих впечатлениях и приобретенных знаниях, прежде всего о самом народе, его быте и культуре и его языке. В 2012 году на основе книги снят документальный фильм «The Grammar of Happiness», рассказывающий о жизни Эверетта среди пираха. В этот период он активно участвует в дискуссиях, защищая свои исследовательские взгляды, дает интервью, пишет новые книги и, как написано в статье о нем, «распространяет свои идеи как сумасшедший» (Leith, 2012). Из «описательного лингвиста» (если вспомнить Н. Хомского) Д. Эверетт превращается в известного теоретика:

«Хотя разногласия будут существовать всегда, за годы, прошедшие с момента написания моей книги, наблюдения за прекрасными языком и культурой пираха повлияли на науку по всему миру. Продолжая исследования, я написал еще несколько книг, которые были приняты благосклонно: „Язык как инструмент культуры“ (Language: The Cultural Tool, 2012); „Темная материя разума: Бессознательное, выраженное в культуре“" (Dark Matter of the Mind: The Culturally Articulated Unconscious, 2016). Кроме того, сейчас я работаю над еще одной, и она будет называться „Как появился язык“ (How Language Began)» (Эверетт, 2016, с. 11).

В нескольких словах нужно напомнить и о гипотезе Сепира-Уорфа. Ее судьба, по существу, началась после смерти обоих ученых. Это касается и названия, и формулировок, и успеха, и неудач. Эдуард Сепир умер в 1939 году, а Бенджамин Уорф в 1941. Пик успеха гипотезы приходится на 50-е годы ХХ века и связан с несколькими событиями. В 1953 году Харри Хойер ученик Сепира и коллега Уорфа - вместе с антропологом Робертом Редфилдом организовал знаменитую междисциплинарную конференцию, посвященную гипотезе, и привлек к ней как ее сторонников, так и противников. Дискуссии оказались весьма плодотворными, и в 1954 году вышли в свет труды конференции (Hoijer, 1954). Вскоре в 1956 году появился и полный сборник статей Уорфа (Carroll, 1956). В 1960 году в первом выпуске «Нового в лингвистике» были опубликованы переводы трех статей Б. Уорфа (Уорф, 1960a, b, с) на русский язык, причем статья «Отношение норм поведения и мышления к языку» (Уорф, 1960а), посвященная сравнению категории времени в европейских языках и языке хопи, может считаться ключевой в смысле изложения гипотезы на конкретном материале.

Интересно отметить, что именно Х. Хойер ввел термин «гипотеза Сепира-Уорфа». Другое название было неточно переведено на русский язык как «гипотеза лингвистической относительности», поскольку в словосочетании linguistic relativity прилагательное относится скорее к языку, чем к лингвистике, и должно переводиться как «языковой». В «именном» же названии гипотезы кроется если не загадка, то по крайней мере вопрос, на который уже не удастся ответить. И название, и формулировка гипотезы в сильной и слабой версиях появились, как уже сказано, после смерти обоих ученых, и это делает чрезвычайно сложным оценку их вклада в теорию. Очевидно, что такое название - дань уважения, но в принципе можно представить себе и ситуацию, когда гипотеза называлась бы именем только одного из них. Эдуард Сепир, безусловно, имеет больший авторитет в науке и сказал на эту тему достаточно для того, чтобы считать, что именно он создатель гипотезы, а его ученики, включая Б. Уорфа, лишь доформулировали ее. С другой стороны, может быть, как раз радикализм гипотезы требовал в авторы не всеми почитаемого Сепира, корректно формулировавшего общие тезисы о связи языка и культуры, а человека отчасти «со стороны», сделавшего более резкие и более спорные утверждения. Имя Сепира выступает здесь в качестве своего рода репутационной поддержки, но в принципе его могло бы и не быть. История во многом развивала именно этот сценарий, поскольку, во-первых, из двух создателей гипотезы основную критику принял на себя Бенджамин Уорф, а во-вторых, имя Сепира порой исчезало из названия данной системы взглядов, и речь шла просто об уорфианстве.

Последующие после 50-х годов десятилетия стали временем критики как самой гипотезы, так и Бенджамина Уорфа, его исследований и высказываний. Наиболее жестко гипотеза подверглась критике с позиций универсальной грамматики, то есть со стороны Ноама Хомского и хомскианцев (см., например, Пинкер, 2004). Н. Хомский полагает, что языковая способность ${ }^{4}$ человека является врожденной, или, иначе говоря, универсальная грамматика как некий механизм встроена в мозг. Именно этот механизм помогает ребенку осуществить сложнейшую процедуру усвоения языка за несколько лет. В более позднем возрасте - примерно после 12 лет - этот механизм утрачивается, и взрослый человек прилагает для изучения иностранного языка значительно большие интеллектуальные усилия, достигая при этом худшего результата. «Универсальность» подразумевает наличие определенных черт, общих для всех языков, в частности рекурсии (о ней речь пойдет ниже). Это вытекает из того, что овладение любым конкретным языком основывается на общем и довольно абстрактном языковом механизме, встроенном в мозг. Также важно понимать, что языковая способность автономна и независима от интеллектуальных способностей человек. Таким образом, в соответствии с концепцией универсальной грамматики язык и мышление существуют независимо, то есть не связаны друг с другом и не оказывают друг на друга влияния.

В 1983 году появилась книга Экхарта Малотки о времени в языке хопи (Malotki, 1983), которая стала сильнейшим ударом по исследовательской репутации Б. Уорфа. На первой странице книги располагались всего две фразы. Одна - цитата из Уорфа, где он утверждал, что в языке хопи нет ни слов, ни грамматических форм, ни конструкций или выражений, которые бы прямо соотносились с тем, что мы называем временем. Под этой цитатой следовали предложение на языке хопи и его перевод на английский. По-русски это бы звучало так: «Тогда на следующий день довольно

\footnotetext{
4 Здесь сказано о языковой способности (в единственном числе), чтобы отличать ее от языковых способностей (во множественном числе), под которыми обычно понимаются способности взрослого человека к изучению иностранных языков.
} 
рано утром, в час, когда люди молятся солнцу, примерно в это время он снова разбудил девушку». Иначе говоря, уже на первой странице Э. Малотки полностью перечеркивал выводы, сделанные Уорфом о времени в языке хопи. Далее он утверждал, что не нашел доказательств утверждениям Уорфа ни в исторических документах, ни при опросах носителей языка в 1980-е годы. Книга Э. Малотки оказалась не только конкретным и болезненным ударом по научной репутации Б. Уорфа, но и своего рода опровержением гипотезы лингвистической относительности, пусть даже не в логическом, но психологическом отношении.

Этих фактов достаточно, чтобы перейти к сравнению двух систем взглядов и тех социальных ролей, которые их создатели сыграли в научной и культурной жизни своей эпохи.

\section{Даниел Эверетт - это Бенджамин Уорф XXI века}

Социальные и научные роли Б. Уорфа и Д. Эверетта, а также выдвигаемых ими теорий во многом похожи, хотя название этого раздела, конечно, метафора. Я бегло перечислю те сближающие их пункты (ситуации, события, качества, характеристики), которые важны для понимания места этих ученых в истории лингвистики. Биографические факты взяты из английской Википедии и других источников (Benjamin Lee Whorf; Daniel Leonard Everett; Звегинцев, 1960; Эверетт, 2016).

Во-первых, этим исследователям сопутствует миф о непрофессионализме. Оба ученых воспринимаются многими лингвистами как непрофессионалы, дилетанты, то есть чужие для лингвистического сообщества. Это в большей степени касается Б. Уорфа, не имевшего лингвистического образования. Он закончил Массачусетский технологический институт по специальности химик-технолог и всю жизнь проработал в страховой компании. Д. Эверетт закончил Чикагский библейский институт Муди и Летний институт лингвистики, где его готовили как миссионера и переводчика Библии. Мнение об отсутствии лингвистического образования отчасти использовалось как аргумент в теоретических спорах. Вместе с тем «дилетантизм» обоих ученых не более чем миф, поскольку отсутствие базового образования компенсировалось последующими штудиями, включающими и самообразование, и самостоятельную научную работу, а затем и преподавание. Надо помнить, что Б. Уорф посещал курсы Э. Сепира в Йеле, а позднее заменял тяжело больного учителя уже как лектор. Он активно изучал юто-ацтекские языки, написав о них целый ряд работ. Д. Эверетт, в свою очередь, получил образование как полевой лингвист в уже упомянутом Летнем институте лингвистики, защитил диссертацию о языке пираха, написанную в идеологии порождающей грамматики, был профессором в ряде университетов, а в каких-то из них возглавлял лингвистические кафедры, стал автором нескольких лингвистических книг, в том числе и теоретических.

Во-вторых, они оба получили почти эксклюзивный доступ к экзотическому языку - и на основе этого языка как раз и сформулировали свои теоретические взгляды. Для Б. Уорфа таким языком стал хопи, относящийся к юто-ацтекской семье, а для Д. Эверетта пираха, язык Амазонии, единственный сохранившийся диалект языка мура. Первоначально их результаты принимались на веру, и лишь потом другие исследователи стали критически переоценивать их выводы и сам материал. Для Б. Уорфа главным и роковым критиком в этой области стал Э. Малотки, а для Д. Эверетта - его оппоненты по журналу Language, Э. Невинс, Д. Песецки и С. Родригес.

B-третьих, в процессе исследования они чрезвычайно доброжелательно относятся к изучаемым языку и культуре. Это можно считать одним из основных принципов американской этнолингвистики и школы Франца Боаса, к которой принадлежал Б. Уорф. Более чем красноречивы и слова Д. Эверетта из предисловия к русскому изданию. Кроме уже упомянутой выше цитаты о том, как пираха сделали миссионера свободомыслящим атеистом и как он благодарен им за это, я приведу еще две цитаты:

«Народ пираха оказал воздействие не только на науку: важнее то, что его культура и язык повлияли на отношение многих людей к жизни. Люди из самых разных стран пишут мне о том, как в трудную минуту пираха помогли им поновому взглянуть на жизнь».

«Я знаю индейцев пираха едва ли не сорок лет, а почти восемь лет я жил среди них - и каждый день благодарю их за это» (Эверетт, 2016, с. 12).

В-четвертых, оба исследователя были не вполне последовательны даже по отношению к конкретному материалу. Д. Эверетт принципиально поменял свою позицию, перейдя из лагеря генеративистов и последователей Н. Хомского в лагерь его критиков. Непоследовательность Б. Уорфа отмечена, например, одним из его недавних критиков, Гаем Дойчером:

«Поэтому Уорф находит „неправомерным полагать, что индеец хопи, который знает лишь язык хопи и культурные идеи своего общества, имеет те же понятия... времени и пространства, что и мы“. Хопи, говорит он, не понял бы нашей идиомы „завтра будет другой день“, потому что для них возвращение дня „ощущается как возвращение того же человека, немного старше, но со всеми следами вчерашнего дня, а не как „другой день“, т. е. как совершенно другой человек“» (Дойчер, 2016, с. 182).

«Но это было только начало. По мере углубления его исследований индейцев хопи Уорф решил, что предыдущий анализ был недостаточно точен и что язык хопи на самом деле вообще не содержит указаний на время. Он стал объяснять, что в хопи нет „слов, грамматических форм, конструкций или выражений, которые напрямую относились бы к тому, что мы называем „временем“, или к прошлому либо будущему, длящемуся или законченному действию“» (там же). 
Таким образом, хопи «не имеют общего понятия или представления [времени]... как гладко текущего континуума, в котором все во вселенной происходит с одинаковой скоростью» (там же).

Именно самое радикальное высказывание Б. Уорфа о времени в языке хопи и опровергает Э. Малотки, приводя его на первой странице. И его же подхватывает и критикует Г. Дойчер: «После долгого и тщательного изучения и анализа можно рассматривать язык хопи как не содержащий слов, грамматических форм, конструкций или выражений, которые прямо относились бы к тому, что мы называем „время“» (Дойчер, 2016, с. 183).

B-пятых, интересно, что оба ученых формулируют свои языковые открытия в языках хопи и пираха, опираясь, скорее, на отрицание определенных фактов и свойств. Для Б. Уорфа это характерно в меньшей степени, но в приведенных выше цитатах речь идет именно об отрицании привычного для европейцев времени. Позитивная часть сформулирована менее отчетливо, хотя в статье «Отношение норм поведения и мышления к языку» (Уорф, 1960а) она, безусловно, присутствует.

Критики Д. Эверетта сформулировали и оспорили 11 его утверждений о языке пираха (Nevins et al., 2009).

Для синтаксиса это:

1. Отсутствие вложения.

Для лексикона и семантики это:

2. Отсутствие чисел, самого понятия счета и любых слов для квантификации.

3. Отсутствие слов для цвета.

4. Простейший из известных инвентарь местоимений.

5. Отсутствие «относительных времен».

Для культуры это:

6. Отсутствие мифов о создании и вымысла вообще.

7. Отсутствие рисунков или вообще искусства.

8. Моноязычность индейцев пираха (в контексте более чем 200-летних регулярных контактов с бразильцами).

9. Отсутствие индивидуальной или коллективной памяти более чем на два поколения назад.

10. Простейшая из известных система родства.

11. Одна из простейших среди известных материальных культур.

Чрезвычайно важным следует считать и принцип ограничения коммуникации непосредственным опытом, названный самим Д. Эвереттом «принципом непосредственности восприятия» ${ }^{\mathbf{5}}$ Ему посвящена седьмая глава книги (Эверетт, 2016). Существование этого принципа противоречит критерию перемещаемости

\footnotetext{
5 Исследование принципа непосредственного восприятия в языке и мышлении и его связи с социальным и культурным укладом вступает в неожиданную перекличку с отечественными исследованиями психолога А.Р. Лурии, проведенными на основе экспедиций в 1930-х годах в Среднюю Азию (в основном в Узбекистан). В частности, некоторые группы испытуемых отказывались делать простейшие умозаключения, не имея соответствующего личного опыта (Лурия, 1974).
}

языка, что согласно Чарльзу Хоккету отличает человеческую коммуникацию от коммуникации животных.

Из-за того, что в основе взглядов Д. Эверетта лежит набор отрицаний, касающийся одного языка, трудно говорить о создании полноценной теории.

Формулировки этих утверждений содержат ключевые слова «отсутствие» или «простейший» и могут быть названы пробелами как в грамматике, так и в культуре. Критики оспаривают либо сам факт существования пробела, либо его исключительность среди языков мира. При этом, говоря о языке, они опираются в основном на материал самого Д. Эверетта. Говоря о культуре, они используют и другие источники (например, Gonçalves, 1993; 2001).

В-шестых, общим для двух теоретических систем становится преодоление лингвистикой собственной изоляции, при этом Б. Уорф следует в русле богатой этнолингвистической традиции и продолжает линию Ф. Боаса и Э. Сепира, объединявших в качестве объекта исследования язык и культуру. Д. Эверетт в своем противостоянии Н. Хомскому отчасти сближается с этой традицией. Фактически, хотя это и не проговаривается специально, он вносит свой вклад в поддержку гипотезы лингвистической относительности своей собственной борьбой с универсальной грамматикой.

Для Эверетта, впрочем, не имеет принципиального значения направление отношений между языком и мышлением. Важен лишь сам факт корреляции между ними. Впрочем, если мы обратимся к уже упоминавшейся статье Уорфа (1960а), то придется признать, что и в ней прежде всего фиксируется корреляция между языком и нормами поведения и мышления, но едва ли четко определяется направление влияния.

Еще одним, возможно околонаучным, фактором, объединяющим теоретические взгляды ученых, становится их особое отношение к роли лингвистики в среде гуманитарных наук и - как следствие - привлечение общественного внимания к их деятельности и к лингвистике в целом. Выход в междисциплинарное пространство обеспечивает ей важное место в научной иерархии, а изучение и сравнение языков (в том числе экзотических) приобретает престиж.

Научные биографии двух исследователей (для Б. Уорфа в большей степени посмертная) порой пересекаются. По существу, работы Д. Эверетта подводят черту под дискуссиями об истинности гипотезы Сепира-Уорфа. Связь языка и мышления у пираха имеет место, но сказать, что речь идет именно о влиянии языка, невозможно. Скорее, третий компонент - культура (или, скажем, цивилизация) - оказывает влияние и на язык, и на мышление. Так, отсутствие числительных в языке и неумение считать, свойственное индейцам пираха, сложились в результате определенного образа жизни. Объединяет Б. Уорфа с Д. Эвереттом и существование главного идеологического противника универсальной грамматики и непосредственно Ноама Хомского. Наконец, совсем уж странный биографический зигзаг состоит в том, что сын Дэниела Эверетта - Калеб, став ученым-антропологом, пишет книгу о лингвистической относительности (Everett C., 2013).

Подводя итог, можно сказать, что вклад и Б. Уорфа, и Д. Эверетта никак не сводится к конкретному 
описанию экзотического языка. Точность их наблюдений может вызывать сомнения, но это ни в коей мере не отменяет ценности дискуссии, которую они спровоцировали. Для гипотезы Сепира-Уорфа уже вполне ясна неуместность как ее подтверждения, так и опровержения. Ее роль в науке определяется не ее истинностью, а тем массивом исследований, для которых она служила своего рода методологией и одновременно стимулом. Значимость взглядов Д. Эверетта менее очевидна, но вполне возможно, что он участвует в построении некой новой модификации гипотезы лингвистической относительности, которую уже и не следует так называть. Речь идет о комплексном и, естественно, междисциплинарном изучении языка и культуры в корреляции - говоря словами Уорфа - с нормами поведения и мышления.

\section{Литература}

Дойчер Г. Сквозь зеркало языка: почему на других языках мир выглядит иначе. М.: АСТ, 2016.

Дронов П.С. Так ли уж несовместимы точки зрения Д. Эверетта и генеративистов? // Послесловие к кн.: Эверетт Д. Не спи - кругом змеи. Быт и язык индейцев амазонских джунглей. М.: ЯСК, 2016. С.309-324.

Звегинцев В.А. Теоретико-лингвистические предпосылки гипотезы Сепира-Уорфа // Новое в лингвистике. Выпуск 1 / Под ред. В.А. Звегинцева. М.: Издательство иностранной литературы, 1960. С.111-134.

Комелев А.Д. Пираха как пример языка, «застывшего» на начальной стадии эволюции // Послесловие к кн. Эверетт Д. Не спи - кругом змеи. Быт и язык индейцев амазонских джунглей. М: ЯСК, 2016. С.341 - 378.

Кронгауз М.А. Пирахан. Arzamas. 2017a. URL: http:// arzamas.academy/micro/language/ 17 .

Кронгауз М.А. Бенджамин Уорф XXI века // Youtube. 2017. URL: https://www.youtube.com/watch?v=EGrMUZjRPQE. Кронгауз М.А., Пиперски А. Ч., Сомин А. А., и др. Сто языков. Вселенная слов и смыслов. М.: АСТ, 2018.

Лурия А.Р. Об историческом развитии познавательных процессов: экспериментально-психологическое исследование. М.: Наука, 1974.

Никулин А.В. Насколько необычен язык пираха? // Послесловие к кн.: Эверетт Д. Не спи - кругом змеи. Быт и язык индейцев амазонских джунглей. М: ЯСК, 2016. C. $325-340$ 2004.

Пинкер С. Язык как инстинкт. М.: Едиториал УРСС,

Пирахан // Википедия. URL: https://ru.wikipedia.org/ wiki/Пирахан (язык) (Дата обращения 21.03.2018).

Уорф Б.Л. Отношение норм поведения и мышления к языку // Новое в лингвистике. Выпуск 1 / Под ред. В.А. Звегинцева. М.: Издательство иностранной литературы, 1960 C. $135-168$

Уорф Б. Л. Наука и языкознание (О двух ошибочных воззрениях на речь и мышление, характеризующих систему естественной логики, и о том, как слова и обычаи влияют на мышление) // Новое в лингвистике. Выпуск 1 / Под ред. В.А. Звегинцева. М.: Издательство иностранной литературы 1960. C. $169-182$

Уорф Б.Л. Лингвистика и логика // Новое в лингвистике. Выпуск 1 / Под ред. В.А. Звегинцева. М.: Издательство иностранной литературы, 1960. С.183-198.

Эверетт Д. Не спи - кругом змеи. Быт и язык индейцев амазонских джунглей. М.: ЯСК, 2016.

Anthony A. Lost for words in the Amazon // The Guardian 2008, Nov 16. URL: https://www.theguardian.com/books/2008/ nov/16/amazon-everett-book-review.

Bartlett T. Angry Words // The Chronicle of the Higher Education. 2012, Mar 20. URL: http://www.chronicle.com/article/ Angry-Words/131260.

Benjamin Lee Whorf // Wikipedia. n.d. URL: https:// en.wikipedia.org/wiki/Benjamin Lee Whorf (21.02.2018).

Daniel Leonard Everett // Wikipedia. n.d. URL: https:// en.wikipedia.org/wiki/Daniel Everett (21.02.2018). Everett $C$. Linguistic relativity. Evidence across languages and cognitive domain. Berlin; Boston: De Gruyter Mouton, 2013. doi:10.1515/9783110308143

"Ele virou um charlatão", diz Chomsky. Da Redação // Folha de S. Paulo. 2009, Feb 02. URL: http://www1.folha.uol.com.br/fsp/ ciencia/fe0102200904.htm.

Everett $D$. A língua Pirahã e a teoria da sintaxe : descrição, perspectivas e teoria.Campinas: Unicamp, 1991.

Everett D. Cultural constraints on grammar and cognition in Pirahã // Current Anthropology. 2005. Vol.46. No.4. P.621 - 646. doi:10.1086/431525

Everett D. Don't sleep, there are snakes: Life and language in the Amazonian jungle. New York: Pantheon Books, 2008.

Everett D. Pirahã culture and grammar: A response to some criticisms // Language. 2009.Vol.85. No.2.P.405 - 442. doi:10.1353/ lan.0.0104

Gonçalves M.A. O significado do nome: Cosmologia e nominação entre os Pirahã. Rio de Janeiro: Sette Letras, 1993.

Gonçalves M.A. O mundo inacabado. Ação e criação em uma cosmologia amazônica. Rio de Janeiro: Editora da UFRJ, 2001.

Language, thought, and reality: Selected writings of Benjamin Lee Whorf / J.B. Carroll (Ed.). Cambridge, Massachusetts: Technology Press of Massachusetts Institute of Technology, 1956.

Language in culture: Conference on the interrelations of language and other aspects of culture / H. Hoijer (Ed.). Chicago: University of Chicago Press, 1954.

Leith W. Daniel Everett: lost in translation // The Telegraph. 2012, Apr 10. URL: http://www.telegraph.co.uk/culture/books/ authorinterviews/9186354/Daniel-Everett-lost-in-translation.html.

Malotki E. Hopi time. Berlin: Mouton de Gruyter, 1983 doi:10.1515/9783110822816

McCrum R. Daniel Everett: 'There is no such thing as universal grammar' // The Guardian. 2012, Mar 25. URL: https://www.theguardian.com/technology/2012/mar/25/

daniel-everett-human-language-piraha.

Nevins A., Pesetsky D., Rodrigues C. Pirahã exceptionality: A reassessment // Language. 2009. Vol.85. No.2. P.355-404. doi:10.1353/lan.0.0107

Piraha Debate // Youtube. 2011, Dec 18. URL: https://www. youtube.com/watch?v=OIbD7O79Goc (21.02.2018).

Suddath C. Don't sleep, there are snakes // Time. 2008, Nov 17. URL: http://content.time.com/time/arts/article/0,8599,1859528,00.html. 


\title{
Daniel Everett and Benjamin Whorf: Linguistic and Non- Linguistic Parallels
}

\section{Maxim Krongauz}

National Research University Higher School of Economics; Russian State University for the Humanities, Moscow, Russia

\begin{abstract}
This article analyzes the similarities between the scientific biographies of Benjamin Lee Whorf, one of the authors of the hypothesis of linguistic relativity, and Daniel Everett, who described the Pirahã language. It discusses their roles in contemporary scientific communities and society in general, as well as their views and achievements. The analysis examines the similarity of their scientific destinies, the tremendous success of their theoretical constructions, outstepping the boundaries of linguistics, and the associated critical impact on their reputations. However questionable might be the accuracy of specific observations, it does not change the value of the discussions they provoked. The role of the hypothesis of linguistic relativity in science is determined not by its verity, but by the array of studies for which it has become both a methodology and an incentive. Everett participates in the construction of its new version, that is a complex and interdisciplinary study of language and culture in correlation with the norms of behavior and thinking.
\end{abstract}

Correspondence: Maxim Krongauz,mkronhaus@yandex.ru, 21/4 Staraya Basmannaya str., office 528, 105006 Moscow, Russia

Keywords: Benjamin Lee Whorf, Daniel Everett, linguistic relativity, Hopi language, category of time, Pirahã language, recursion, universal grammar, Noam Chomsky

Copyright () 2018. Maxim Krongauz. This is an open-access article distributed under the terms of the Creative Commons Attribution License (CC BY), which permits unrestricted use, distribution, and reproduction in any medium, provided that the original author is credited and that the original publication in this journal is cited, in accordance with accepted academic practice.

Acknowledgements. Studies underlying this paper were conducted with the support of RFBR Grant \#18-012-00712.

Received May 16, 2017, accepted February 21, 2018.

\section{References}

Anthony, A. (2008, Nov 16). Lost for words in the Amazon. The Guardian. Retrieved from https://www.theguardian.com/ books/2008/nov/16/amazon-everett-book-review.

Bartlett, T. (2012, Mar 20). Angry Words. The Chronicle of the Higher Education. Retrieved from http://www.chronicle. com/article/Angry-Words/131260.

Benjamin Lee Whorf. (n.d.). Wikipedia. Retrieved from https:// en.wikipedia.org/wiki/Benjamin Lee Whorf.

Carroll, J.B. (Ed.). (1956). Language, thought, and reality: Selected writings of Benjamin Lee Whorf. Cambridge, Massachusetts: Technology Press of Massachusetts Institute of Technology.

Deutscher, G. (2010). Through the language glass. New York: Metropolitan Books, Henry Holt and Company. Retrieved from http://f.javier.io/rep/books/Through\%20the\%20 language $\% 20$ glass.pdf.

Dronov, P.S. (2016). Tak li uzh nesovmestimy tochki zreniya D. Everetta i generativistov? [Are Everett's and generativist perspectives so inconsistent? An afterword]. In D. Everet Ne spi - krugom zmei. Byt i yazyk indeitsev amazonskikh dzhunglei [Don't sleep, there are snakes: Life and language in the Amazonian Jungle] (P.S. Dronov, I.V. Mokin, E. N. Panov, Trans. into Russian) (pp.309-324). M: LRC Publishers. (In Russian).

Daniel Leonard Everett. (n.d.). Wikipedia. Retrieved from https:// en.wikipedia.org/wiki/Daniel Everett

"Ele virou um charlatão", diz Chomsky. Da Redação (2009, Feb 02). Folha de S. Paulo, (In Portuguese). Retrieved from http:// www1.folha.uol.com.br/fsp/ciencia/fe0102200904.htm.

Everett, C. (2013). Linguistic relativity. Evidence across languages and cognitive domain. Berlin; Boston: De Gruyter Mouton. doi:10.1515/9783110308143

Everett, D. (1991). A língua Pirahã e a teoria da sintaxe : descrição, perspectivas e teoria. Campinas: Unicamp. (In Portuguese).

Everett, D. (2005). Cultural constraints on grammar and cognition in Pirahã. Current Anthropology, 46(4), 621-646. doi:10.1086/431525

Everett, D. (2008). Don't sleep, there are snakes: Life and language in the Amazonian jungle. New York: Pantheon Books.

Everett, D. (2009). Pirahã culture and grammar: A response to some criticisms. Language, 85(2), 405-442. doi:10.1353/ lan.0.0104 
Everett, D. (2016). Ne spi-krugom zmei. Byt i yazyk indeitsev amazonskikh dzhunglei [Don't sleep, there are snakes: Life and language in the Amazonian Jungle] (P.S. Dronov, I. V. Mokin, E. N. Panov, Trans. into Russian). M: LRC Publishers. (In Russian).

Gonçalves, M.A. (1993). O significado do nome: Cosmologia e nominação entre os Pirahã. Rio de Janeiro: Sette Letras. (In Portuguese).

Gonçalves, M.A. (2001). O mundo inacabado. Ação e criação em uma cosmologia amazônica. Rio de Janeiro: Editora da UFRJ. (In Portuguese).

Hoijer, H. (Ed.). (1954). Language in culture: Conference on the interrelations of language and other aspects of culture. Chicago: University of Chicago Press.

Koshelev, A.D. (2016). Pirakha kak primer yazyka, "zastyvshego" na nachalnoi stadii evolyutsii. Posleslovie [Piraha as a case of language that stopped on the initial stages of its development. An afterword]. In D. Everett Ne spi - krugom zmei. Byt i yazyk indeitsev amazonskikh dzhunglei [Don't sleep, there are snakes: Life and language in the Amazonian Jungle] (P.S. Dronov, I. V. Mokin, E. N. Panov, Trans. into Russian) (pp. 341 - 378). M: LRC Publishers. (In Russian).

Krongauz, M.A. (2017a). Pirahã. Arzamas. (In Russian). Retrieved from http://arzamas.academy/micro/language/17

Krongauz, M. A. (2017b). Bendjamin Whorf XXI veka [Bendjamin Whorf of the XXI century]. Youtube (In Russian). Retrieved from https://www.youtube.com/watch?v=EGrMUZjRPQE.

Krongauz, M.A., Piperski, A.C., \& Somin, A.A. (2018). Sto yazykov. Vselennaya slov $i$ smyslov [A hundred languages. The universe of words and meanings]. Moscow: Izdatelstvo AST. (In Russian).

Leith, W. (2012, Apr 10). Daniel Everett: lost in translation. The Telegraph, Retrieved from http://www.telegraph.co.uk/ culture/books/authorinterviews/9186354/Daniel-Everettlost-in-translation.html.

Luria, A.R. (1974). Ob istoricheskom razvitii poznavatelnykh protsessov: eksperimentalno-psikhologicheskoe issledovanie [On historical development of cognitive processes: experimental psychological study]. Moscow: Nauka. (In Russian).
Malotki, E. (1983). Hopi time. Berlin: Mouton de Gruyter. doi:10.1515/9783110822816

McCrum, R. (2012, Mar 25). Daniel Everett: 'There is no such thing as universal grammar'. The Guardian, Retrieved from https://www.theguardian.com/technology/2012/mar/25/ daniel-everett-human-language-piraha.

Nevins, A., Pesetsky, D., \& Rodrigues, C. (2009). Pirahã exceptionality: A reassessment. Language, 85(2), 355-404. doi:10.1353/lan.0.0107

Nikulin, A.V. (2016). Naskolko neobychen yazyk pirakha? Posleslovie [How exceptional is piraha language? An afterword]. In D. L. Everett. Ne spi-krugom zmei! Byt i yazyk indeitsev amazonskikh dzhunglei [Don't sleep, there are snakes: Life and language in the Amazonian Jungle] (P.S. Dronov, I. V. Mokin, E. N. Panov, Trans. into Russian) (pp.325-340). Moscow: LRC Publishers. (In Russian).

Pinker, S. (1994/2007). The language instinct. New York: Harper Perennial Modern Classics.

Piraha Debate. (2011, Dec 18). Youtube. Retrieved from https:// www.youtube.com/watch? $\mathrm{v}=\mathrm{OIbD} 7 \mathrm{O} 79 \mathrm{Goc}$.

Pirahan. (n.d.). Wikipedia (Russian). Retrieved from https:// ru.wikipedia.org/wiki/Пирахан (язык).

Suddath, C. (2008, Nov 17). Don't sleep, there are snakes. Time, Retrieved from http://content.time.com/time/arts/ article/0,8599,1859528,00.html.

Whorf, B.L. (1956). The relation of habital thought and behavior to language. In J. Carroll (Ed.), Language, thought and reality, Selected writings of Benjamin Lee Whorf (pp.134-160). Cambridge, MA: Technology Press of MIT.

Whorf, B.L. (1940). Science and Linguistics. Technology Review, $44,229-231$.

Whorf, B.L. (1941). Languages and Logic. Technology Review, 43, $250-252$

Zvegintsev, V.A. (1960). Teoretiko-lingvisticheskie predposylki gipotezy Sepira-Whorfa [The linguistic theoretical premises of the Sapir-Whorf hypothesis]. In V.A. Zvegintsev (Ed.), Novoe v lingvistike. Vypusk 1 [Novel in Linguistics. Issue 1] (pp.111-134). Moscow: Izdatelstvo inostrannoi literatury. (In Russian). 


\section{Язык пираха}

\section{и разговорная речь}

\section{Светлана Анатольевна Бурлак}

Институт востоковедения РАН;

Филологический факультет МГУ имени М.В. Ломоносова, Москва, Россия

Аннотация. Впечатление Дэниела Эверетта (см., например, Эверетт, 2016) об исключительности языка пираха может быть в значительной степени связано с тем, что Эверетт в недостаточной мере учел преимущественно разговорнобытовой характер тех высказываний на языке пираха, которые он записывал. Синтаксис разговорной речи сильно отличается от синтаксиса, используемого в письменных текстах. В разговорной речи нередки высказывания, где синтаксические связи между произнесенными словами не могут быть прослежены непосредственно. Связь элементов рассказа может обеспечиваться повторами. Для разговорной речи характерно избегание именных групп с двумя прилагательными, а также конструкции с несколькими генитивами. Предположительно, особенностями функционирования языка в обиходно-бытовой сфере может быть объяснено и отсутствие числительных в пираха.

Контактная информация: Светлана Анатольевна Бурлак, svetlana.burlak@bk.ru, languages@bk.ru; 107031, Mосква, ул. Рождественка, 12, Институт востоковедения РАН.

Ключевые слова: язык пираха, устная речь, синтаксис, ЭДЕ, именная группа, универбация, числительные

(c) 2018 Светлана Анатольевна Бурлак. Данная статья доступна по лицензии Creative Commons "Attribution" («Атрибуция») 4.0. всемирная, согласно которой возможно неограниченное распространение и воспроизведение этой статьи на любых носителях при условии указания автора и ссылки на исходную публикацию статьи в данном журнале в соответствии с канонами научного цитирования.

Статья поступила в редакцию 13 апреля 2017 г. Принята в печать 21 февраля 2018 г.

В 2016 году в издательском доме «ЯСК» вышел русский перевод книги Дэниела Эверетта «Не спи - кругом змеи! Быт и язык индейцев амазонских джунглей» (Эверетт, 2016). Автор, долгие годы исследовавший в полевых условиях язык индейцев пираха, пришел к выводу, что этот язык нарушает множество самых, казалось бы, основополагающих языковых универсалий. Прежде всего, в этом языке, по мнению Эверетта, нет рекурсии - информанты при просьбе перевести ту или иную конструкцию с большим числом вложений строили на пираха синтаксически гораздо более простую конструкцию, и даже в спонтанной речи, обращенной к своим соплеменникам, не использовали сложноподчиненных предложений и других конструкций, требующих рекурсивного вложения составляющих. Автора, приверженца теории Ноама Хомского, такое положение вещей чрезвычайно удивляет.

Однако, как оказывается при ближайшем рассмотрении материала, приводимого самим же Эвереттом в более ранних описаниях пираха (Everett, 1986; 1987), никаких оснований для постулирования особой уникальности этого языка нет. Э. Невинс, Д. Песецкий и С. Родригес (Nevins et al., 2009a,b) подробно и обстоятельно показали, что собранные Эвереттом данные не опровергают современных представлений о языке вообще и о синтаксисе в частности. В их работах приведены многочисленные примеры из самых разных языков - немецкого, ланго (нило-сахарская семья), хинди, бенгали, тибетского, ваппо (семья юки) и др. Эти примеры показывают, что сходные (а иногда и просто в точности такие же) модели и ограничения действуют далеко не только в пираха. Так, например, запрет на именную группу вида GGN действует не только в пираха, но и в немецком ( ${ }^{*}$ Hans-ens Auto's Motor «мотор машины Ганса») (Nevins et al. 2009a, p. 367). Примечательно, что некоторые из моделей и ограничений, которые приводятся Эвереттом как уникальные для пираха, являются, как показано в работе А. Айхенвальд и Р. Диксона (Aikhenvald, Dixon, 1999), совершенно обычными для языков Амазонии.

В целом ряде случаев Эверетт, по-видимому, неверно анализирует собранный им материал (Nevins et al., 2009a). Так, вложенные предикации в пираха вполне возможны, при этом подчиненный предикат оформляется номинализатором -sai и теряет возможность принимать показатели глагольных категорий (примерно так же, как в тюркских языках, см., напримep, Koptjevskaja-Tamm (1993)): 
hi ob-áaxái

'Он действительно умеет делать стрелы.'

(Everett, 1986, p. 263)

(INTNS - интенсификатор,

NOMLZR - номинализатор)

Интересно, тем не менее, задаться вопросом, почему же все-таки высказывания на языке пираха создали у Эверетта впечатление такой «синтаксической недостаточности». Как кажется, это было следствием того, что Эверетт в недостаточной степени учел преимущественно разговорно-бытовой характер тех высказываний на языке пираха, которые он записывал.

Между тем, если обратиться не к письменному языку, а к устной, разговорной речи, в особенности к разговорно-бытовому регистру, мы увидим крайне похожие феномены. Например, по-русски можно сказать: «Не хотят пираха придаточные - вот и не используют» (или «...ну и не используют»). Звучит эта фраза совершенно нормально (хотя на письме выглядит излишне разговорной), но никакого маркера подчинительной связи в ней нет: слова вот или ну вполне возможны и в простых предложениях. В письменном языке, возможно, для выражения этого смысла стоило бы воспользоваться подчинительным союзом: Поскольку пираха не хотят использовать придаточные предложения, они не используют их. Вообще, разговорная речь зачастую не требует сложного синтаксиса, а нередко даже и простого - по крайней мере, никакого поверхностного выражения синтаксических связей между словами в таких высказываниях не усматривается (см. примеры ниже). Причина этого - в том, что при наличии ситуативной привязки (а разговорная речь используется именно в этих условиях) бывает достаточно лишь минимального указания на те или иные существенные детали, собрать же их в единую конструкцию собеседник легко может и сам. Ср. такие примеры из книги Е.А. Земской, М.В. Китайгородской и Е.Н. Ширяева «Русская разговорная речь. Общие вопросы. Словообразование. Синтаксис»: Отодвинь сnать (один из членов семьи побуждает другого отодвинуть кресло, чтобы можно было разложить диван и уложить спать приехавшего гостя) (Земская и др. 1981, с. 192); Выключи готова// (там же, с. 210) «Выключи газ, поскольку картошка уже готова»; Позвони в лес (Бабушка советует внуку пригласить друга на прогулку - звонить предполагается на домашний телефон, поскольку мобильные телефоны еще не появились) (там же, с. 193), - а также пример, приводимый самим Эвереттом: $I$... am ... job? (человек звонит по объявлению об устройстве на работу) (Эверетт, 2016, с. 218). Речь пираха практически всегда протекает именно в этих условиях, так что неудивительно, что подчинительные союзы в этом языке используются редко.

Некоторое исключение составляют рассказы: в случае, когда собеседник не является непосредственным свидетелем описываемых событий, синтаксис уместен, поскольку позволяет выразить взаимоотношения между отдельными деталями ситуации, не явленной в ощущении. Однако, как показывает практика, даже в этом случае средства выражения синтаксической связи между предложениями могут оказаться необязательными. В качестве примера можно сравнить рассказ Каабооги о том, как он убил пантеру (ягуара-меланиста) (Эверетт, 2016, с. 136), и рассказ Михаила Зощенко «Происшествие» (в предположении, что подстрочные переводы точно передают структуру оригинала):

Вот ягуар убил собаку, прыгнул на нее.

На нее, на собаку, прыгнул ягуар. Я думал, я это видел.

И вот я, значит, пантера прыгнула на мою собаку.

Тогда пантера прыгнула на мою собаку.

Тогда я сказал. Это все сделала пантера.

И едет, между прочим, в этом вагоне среди других такая вообще бабешечка. Такая молодая женщина с ребенком.

У нее ребенок на руках. Вот она с ним и едет. Она едет с ним в Новороссийск. У нее муж, что ли, там служит на заводе. Вот она к нему и едет.

Для обоих текстов характерны многочисленные повторы, а также отсутствие союзов. Эверетт характеризует это как подчинение не синтаксическое, а смысловое и связывает его с постулируемым им принципом непосредственности опыта. По-видимому, его вывод о том, что для нормальной человеческой коммуникации наличие синтаксически оформленного подчинения не обязательно, верен. И, как показывает пример из Зощенко, язык пираха в этом смысле не уникален. Отметим также, что каждый из этих рассказов абсолютно нормален с точки зрения обычной структуры устной речи: основной синтаксической единицей устной речи является ЭДЕ (элементарная дискурсивная единица), насчитывающая от двух до четырех слов, повествующая об одном элементарном событии и дающая примерно такое количество информации, которое соответствует обычному для человека объему внимания (Кибрик и др., 2009). С этим хорошо согласуется замечание самого Эверетта о том, что на одно высказывание в языка пираха в норме приходится одно событие (Everett, 2005).

Впрочем, если подстрочные переводы Эверетта с пираха верны, подчинительные союзы в этом языке все-таки иногда употребляются (Эверетт, 2016, c. 136-137): «Так она сделала, что собаки больше нет», «Потом, когда я выстрелил, ягуар, он завалился", «И поэтому я снова выстрелил и сломал ему локоть». Вообще, в нарративе маркированное подчинение должно встречаться чаще, чем в бытовых разговорах; так, в корпусе рассказов о сновидениях случаев бессоюзного подчинения (не списываемого на то, что предшествование по времени иконически выражается предшествованием в рассказе и специальной маркировки не требует) крайне мало: «я была в желтых таких туфлях таких, с такими шнурочками, мама купила», «не найдешь, не знаю что сделаю» (Коротаев и др., 2009, с. 247). На шестьдесят рассказов, записанных от здоровых испытуемых, приходится более 80 случаев использования подчинительных союзов, тогда как случаев, которые можно квалифицировать как 
бессоюзное подчинение (не списываемое на предшествование по времени), всего порядка десяти (абсолютно точные цифры привести невозможно, поскольку из-за речевых сбоев, самоисправлений, длинных пауз для многих случаев возможны разные интерпретации). В бытовых же разговорах, наоборот, редким является наличие союзов, ср. один из очень немногих примеров подобного рода у Земской, Китайгородской и Ширяева: А костюм велик если / поменять можно? (Земская и др., 1981, с. 277).

Остается только пожалеть, что Эверетт не использовал в своих записях транскрипционные конвенции, выработанные для устной речи: из-за этого непонятно, являются ли записи типа «Она сказала. Ягуар ушел далеко» действительно двумя соположенными простыми клаузами или одним сложным предложением. Как показал Н. А. Коротаев, сложные конструкции отличаются от двух соположенных простых, во-первых, по величине пограничных пауз, а во-вторых, по типу акцентной схемы - при этом ни один из этих параметров по отдельности не является достаточным (Коротаев 2009, с. 520). Эверетт пишет, что в конструкциях, где указывается время (типа «Когда я поем, я поговорю с тобой»), между клаузами имеется пауза, и это, по его мнению, доказывает, что это не одно сложное предложение, а два соположенных простых (Everett, 2005). Но в отсутствие необходимых помет трудно судить, достаточна ли эта пауза для признания сентенциальной границы или же правы Невинс и его коллеги, обращающие внимание на то, что пауза в подобных конструкциях (маркируемая на письме запятой) имеется и в английском языке (Nevins et al., 2009a).

В целом предложения, которые Эверетт просил индейцев перевести на пираха, производят крайне неестественное впечатление: «Человек, который поймал рыбу, находится в доме», «Придет или Боб, или Билл», «Кончик хвоста собаки сломан», «Дом брата моего соседа красный», «Старик разделывал больших бурых тапиров». В реальной жизни скорее можно услышать высказывания типа: Там в доме мужик какой-то, он рыбу поймал; Может, Боб придет, может Билл (в китайском языке подобного рода повтор является одним из вариантов оформления общего вопроса, например: 红茶好不好? hóngchá hăo bù hăo - букв. «Черный чай хороший не хороший?» (Ивченко, 2012, с. 109)), У собаки хвост на коние сломан (или У собаки хвост сломан, самыци кончик), У моего соседа у брата дом красный, во всех этих случаях формальное выражение синтаксического подчинения отсутствует.

Фраза типа «Старик разделывал больших бурых тапиров» тоже не очень характерна для разговорной речи; прилагательные, входящие в одну именную группу, встречаются скорее в речи письменной, например: Николаевская художественная школа обретет новые просторные корпуса и т.п.

Подсчеты, проведенные по Национальному корпусу русского языка (НКРЯ), показывают, что в устной непубличной речи сочетания из двух подряд идущих прилагательных встречаются более чем впятеро реже, чем в целом по корпусу, вдвое реже, чем в устной публичной речи (включая речь персонажей театра и кино), и более чем в шесть раз реже, чем в речи про- тотипически письменной (в подсчет вошли художественные, официально-деловые, публицистические, рекламные, учебно-научные и церковно-богословские тексты). Вероятно, имеется корреляция с уровнем образования: в диалектной речи (а ее записывают у людей, не имеющих высшего образования) сочетания из двух подряд идущих прилагательных встречаются вчетверо реже, чем в корпусе устной непубличной речи (и, соответственно, в 25 раз реже, чем в речи прототипически письменной), а среди групп «прилагательное + прилагательное» в устной непубличной речи довольно часты употребления типа «малый симфонический состав», «длинные ультрафиолетовые лучи» или «разные зарубежные вузы». На весь диалектный корпус объемом 285281 слово (из них 3547 прилагательных) таких групп, где два прилагательных (ни одно из которых не субстантивировано) следуют подряд, относятся к одному существительному (типа подарю гарусный красньй плат) и при этом не представляют собой ни устойчивых наименований (типа Старыци Новый год или Ошевенский сельский совет), ни перечислений (типа Мясноё, молочноё и простоё, три говенья), ни повторов (типа пришла бабулька старая-старая), насчитывается всего 44.

В корпусе рассказов о сновидениях А.А. Кибрика и В.И. Подлесской, если два прилагательных неодинаковы, между ними почти всегда есть либо длинные паузы (ср. Мама дала мне ... (0.8) химические' .... (1.5) разные .. (0.6) стеклянные / штуки (Рассказы..., 2009, c. 585, рассказ 024z)), либо граница ЭДЕ; исключений (среди рассказов здоровых испытуемых) всего три: Тамһ ... (0.6) </Ану-у $\mid$ /-новые > всякие большие /-коомнаты были (Рассказы..., 2009, с.585, рассказ 023z), $<$ там оказались> V-прибо-оры разные столо-овые (Рассказы..., 2009, с.592, рассказ 030z), Бегала бездомная / собака, .. (0.2) \большой такой \чёрный \дог (Рассказы..., 2009, с.608, рассказ 046z). В устном подкорпусе НКРЯ (в устной непубличной речи) также (примерно в половине случаев) отмечаются паузы между подряд идущими прилагательными, относящимися к одному существительному.

В русском языке существуют даже специальные приемы, позволяющие избегать именных групп с двумя прилагательными: универбация (см., например, Малышев (2012)) и субстантивация: вместо свежую «Вечернюю Москву» принесли говорят свежую «Вечерку»..., вместо пожилой рабочий человек - пожилой рабочий, вместо неопытные молодые люди - неопытная молодежь и т. п.

Эверетт пишет, что в языке пираха нет числительных (хотя в некоторых примерах фигурирует слово «два»). С одной стороны, охотникам-собирателям считать, в общем-то нечего (и поэтому есть немало языков, где числовой ряд ограничивается единицей и двойкой, cм., например, (Nevins et al., 2009a)). А с другой - для этого феномена возможно и некоторое объяснение с точки зрения разговорной речи. Например, в русском литературном языке слово пара обозначает «два», но если судить только по внешне наблюдаемому поведению, вполне можно прийти к выводу, что это слово значит «некоторое небольшое количество». Так, в ответ на просьбу «дать пару спичек» дадут, скорее всего, не ровно две, а несколько больше (более того, человек, 
давший в ответ на такую просьбу ровно две спички, будет расценен как невежливый или жадный, по крайней мере, если эти спички у него не последние), обещание «перезвонить через пару минут» крайне редко коррелирует с тем, что следующий звонок производится ровно через две минуты. Парадоксальным образом, такое нечеткое обозначение количества в быту нередко оказывается полезнее точного числительного: совет «добавить пару яиц» приведет к лучшему результату, чем совет «добавить два яйца», потому что даст возможность слушающему сделать поправку на размер яиц (если яйца слишком мелкие, лучше будет добавить три, а если особенно крупные, может хватить и одного).

Таким образом, видимо, можно утверждать, что мнение о какой-то особенной уникальности языка пираха не подтверждается, можно говорить лишь об отсутствии у пираха такого регистра, как письменная речь. Но для бесписьменного языка это неудивительно. Более существен вопрос, обращенный к общей теории языка: если в каком-то языке или диалекте все, что мы можем наблюдать, - это разговорная речь в бытовых контекстах, какие выводы мы можем делать о структуре этого языка или диалекта (а также человеческого языка вообще), а какие в такой ситуации не могут быть подтверждены фактическим материалом.

\section{Литература}

Земская Е.А., Китайгородская М.В., Ширяев Е.Н. Русская разговорная речь. Общие вопросы. Словообразование. Синтаксис. М: Наука, 1981.

Ивченко T. Новые горизонты: Интегральный курс китайского языка: В 2 т. Гуанчжоу: Educational Science Publishing House, 2012.

Кибрик А.А., Подлесская В.И., Коротаев Н.А. Структура устного дискурса: основные элементы и канонические явления // Рассказы о сновидениях: корпусное исследование устного русского дискурса / Под ред. А.А. Кибрика, В.И. Подлесской. М.: Языки славянских культур, 2009. С. 55-101.

Коротаев Н.А. Просодическая организация сложноподчиненных конструкций // Рассказы о сновидениях: корпусное исследование устного русского дискурса / Под ред. А.А. Кибрика, В.И. Подлесской. М.: Языки славянских культур, 2009. С. $488-522$.

Коротаев Н. А., Кибрик А. А., Подлесская В. И. Осложнения канонической структуры: на стыке моно- и полипредикативности // Рассказы о сновидениях: корпусное исследование устного русского дискурса / Под ред. А.А. Кибрика, В.И. Подлесской. М.: Языки славянских культур, 2009. С. 219-332.

Мальшев С.В. Закономерности образования слов типа «электричка» в современном русском языке. Дипломная работа. МГУ им. М.В. Ломоносова, М., 2012.

Рассказы о сновидениях: Корпусное исследование устного русского дискурса / Под ред. А.А. Кибрика, В.И. Подлесской. М.: Языки славянских культур, 2009.

Эверетт Д. Не спи - кругом змеи. Быт и язык индейцев амазонских джунглей. М.: Языки славянских культур, 2016.

Aikhenvald A.Y., Dixon R.M.W. Other small families and isolates // The Amazonian languages / R.M.W. Dixon, A.Y. Aikhenvald (Eds.). Cambridge: Cambridge University Press, 1999. P. $341-383$.

Everett $D$. Don't sleep, there are snakes: Life and language in the Amazonian jungle. N.Y.: Pantheon Books, 2008.

Everett D.L. Pirahã // Handbook of Amazonian languages, vol. 1 / D.C. Derbyshire, G.K. Pullum (Eds.). Berlin: Mouton de Gruyter, 1986. P. 200-326.

Everett D.L. A lingua Pirahã e a teoria da sintaxe: Descrição, perspectivas e teoria. Campinas: Editora da Unicamp, 1987.

Everett D.L. Cultural constraints on grammar and cognition in Pirahã: Another look at the design features of human language // Current Anthropology. 2005. Vol.46. No.4. P.621-646. doi:10.1086/431525

Koptjevskaja-Tamm M. Nominalizations. London: Routledge, 1993.

Nevins A., Pesetsky D., Rodrigues C. Pirahã exceptionality: A reassessment // Language. 2009a. Vol.85. No.2. P.355-404 doi:10.1353/lan.0.0107

Nevins A., Pesetsky D., Rodrigues C. Evidence and argumentation: A reply to Everett (2009) // Language. 2009b. Vol.85. No.3. P.671 - 681. doi:10.1353/lan.0.0140 


\title{
Pirahã and Spoken Language
}

\section{Svetlana Burlak}

Institute of Oriental Studies, RAS;

Lomonosov Moscow State University (philological faculty), Moscow, Russia

\begin{abstract}
Daniel Everett's belief that the Pirahã language is an exception from linguistic theory may be due to the fact that Everett did not take proper account of the spoken nature of Pirahã. Spoken language syntax differs considerably from the syntax used in written texts. In spoken language, there are utterances where the words show no obvious connections with each other. Connections between clauses in a narration can be manifested through repetition. In spoken language, noun phrases with two adjectives or two genitives are rare. The absence of numerals in Pirahã may also be accounted for by its functioning as a strictly spoken language.
\end{abstract}

Correspondence: Svetlana Burlak, svetlana.burlak@bk.ru; languages@bk.ru, Institute of Oriental Studies RAS, 12 Rozhdestvenka str., 107031 Moscow, Russia

Keywords: Pirahã language, spoken language, syntax, elementary discourse unit, noun phrase, univerbation, numerals

Copyright ( $)$ 2018. Svetlana Burlak. This is an open-access article distributed under the terms of the Creative Commons Attribution License (CC BY), which permits unrestricted use, distribution, and reproduction in any medium, provided that the original author is credited and that the original publication in this journal is cited, in accordance with accepted academic practice.

Received April 13, 2017, accepted February 21, 2018.

\section{References}

Aikhenvald, A.Y., \& Dixon, R.M.W. (1999). Other small families and isolates. In R.M.W. Dixon, \& A.Y. Aikhenvald (Eds.), The Amazonian languages (pp. 341 - 383). Cambridge: Cambridge University Press.

Everett, D.L. (1986). Pirahã. In D.C. Derbyshire, \& G.K. Pullum (Eds.), Handbook of Amazonian languages, vol.1 (pp. 200 - 326). Berlin: Mouton de Gruyter.

Everett, D.L.(1987). A lingua Pirahã e a teoria da sintaxe: Descrição, perspectivas e teoria. Campinas: Editora da Unicamp.

Everett, D.L. (2005). Cultural constraints on grammar and cognition in Pirahã: Another look at the design features of human language. Current Anthropology, 46(4), 621-646. doi: $10.1086 / 431525$

Everett, D.L.(2008). Don't sleep, there are snakes: Life and language in the Amazonian jungle. N.Y.: Pantheon Books.

Ivchenko, T. (2012). Novye gorizonty: Integralnyi kurs kitaiskogo iazyka [New horizons: Intensive course of Chinese]. Guanchzhou: Educational Science Publishing House. (In Russian).

Kibrik, A.A., Podlesskaya, V.I., \& Korotaev, N.A. (2009). Struktura ustnogo diskursa: Osnovnye elementy i kanonicheskie iavleniia [Oral discourse structure: Main elements and iconic features]. In A.A. Kibrik, \& V.I. Podlesskaya (Eds.), Rasskazy o snovideniiakh: Korpusnoe issledovanie ustnogo russkogo diskursa [Night Dream Stories: A corpus study of spoken Russian discourse] (pp.55-101). Moscow: LRC Publishing. (In Russian).

Koptjevskaja-Tamm, M. (1993). Nominalizations. London: Routledge.
Korotaev, N.A. (2009). Prosodicheskaia organizatciia slozhnopodchinennykh konstruktcii [Prosodic organization of nested constrauctions]. In A.A. Kibrik, \& V.I. Podlesskaya (Eds.), Rasskazy o snovideniiakh: Korpusnoe issledovanie ustnogo russkogo diskursa [Night Dream Stories: A corpus study of spoken Russian discourse] (pp.488 - 522). Moscow: LRC Publishing. (In Russian).

Korotaev, N.A., Kibrik, A.A., \& Podlesskaya, V.I. (2009). Oslozhneniia kanonicheskoi struktury: Na styke mono- i polipredikativnosti [Complications in canonical structures: Between mono- and poly-predicative constructions]. In A.A. Kibrik, \& V.I. Podlesskaya (Eds.), Rasskazy o snovideniiakh: Korpusnoe issledovanie ustnogo russkogo diskursa [Night Dream Stories: A corpus study of spoken Russian discourse] (pp.219 - 332). Moscow: LRC Publishing. (In Russian).

Malyshev, S.V. (2012). Zakonomernosti obrazovaniia slov tipa "elektrichka" $v$ sovremennom russkom iazyke. [Regularities in formation of words like "elektrichka" in modern Russian language]. Unpublished master's thesis, Lomonosov Moscow State University. (In Russian).

Nevins, A., Pesetsky, D., \& Rodrigues, C. (2009a). Pirahã exceptionality: A reassessment. Language, 85(2), 355-404 doi:10.1353/lan.0.0107

Nevins, A., Pesetsky, D., \& Rodrigues, C. (2009b). Evidence and argumentation: A reply to Everett (2009). Language, 85(3), 671-681. doi:10.1353/lan.0.0140

Zemskaia, E. A., Kitaigorodskaia, M.V., \& Shiriaev, E. N. (1981) Russkaia razgovornaia rech. Obshchie voprosy. Slovoobrazovanie. Sintaksis [Russian spoken language. General questions. Word formation. Syntax]. M: Nauka. (In Russian). 


\title{
Тирания чужого ума
}

\author{
Андрей Александрович Кибрик
}

Институт языкознания РАН, Москва, Россия;

МГУ им. М.В. Ломоносова, Москва, Россия

\begin{abstract}
Аннотация. В книге Д. Эверетта «Не спи - кругом змеи» отражена его непростая интеллектуальная эволюция, включая отказ от генеративного подхода к языку. Тем не менее в концепции Эверетта осталось много от впитанного им генеративизма, что и объясняет целый ряд его утверждений относительно уникальности языка пираха. К числу спорных тезисов, отчасти обусловленных таким генезисом взглядов Эверетта, относятся принцип непосредственности восприятия, отсутствие рекурсии, фатического общения и дизъюнкции, полисемия терминов родства. В то же время в книге Эверетта содержится ряд интересных наблюдений, которые действительно представляют пираха как весьма необычный язык и культуру. К их числу принадлежат наблюдения о неумении считать, о чувстве культурного превосходства, о теории относительности. В целом работа Эверетта способствует преодолению европоцентризма, по-прежнему характерного для многих направлений лингвистики.
\end{abstract}

Контактная информация: Андрей Александрович Кибрик, aakibrik@gmail.com; 125009, Москва, Б. Кисловский пер., 1, Институт языкознания РАН.

Ключевые слова: история идей, теория языка, языковое разнообразие, рекурсия, устная речь, числовая когниция

(c) 2018 Андрей Александрович Кибрик. Данная статья доступна по лицензии Creative Commons "Attribution" («Атрибуция») 4.0. всемирная, согласно которой возможно неограниченное распространение и воспроизведение этой статьи на любых носителях при условии указания автора и ссылки на исходную публикацию статьи в данном журнале в соответствии с канонами научного цитирования.

Благодарности. Исследования, лежащие в основе данной статьи, выполнены при поддержке гранта РФФИ № 17-0600460. Автор благодарен М.Б. Бергельсон и О.В. Федоровой за полезные замечания по тексту статьи.

Статья поступила в редакцию 7 мая 2017 г. Принята в печать 28 февраля 2018 г.

\section{Введение}

Как явствует из книги «Не спи - кругом змеи», исследовательская биография Д. Эверетта трудна и драматична. В ходе полевой работы в Бразилии Эверетту довелось сталкиваться с ядовитыми пауками и змеями, анакондами и крокодилами. Он ярко описывает коммуникативные трудности лингвиста, работающего в культурно ином окружении: «И тело, и душа, и мысли, и чувства полевого исследователя, а особенно его восприятие самого себя, испытывают колоссальную нагрузку, и она тем больше, чем более различны между собой его родная культура и культура, которую он постигает» (Эверетт, 2016, с. 37). Однако все эти внешние обстоятельства вполне предсказуемы, и они возникают у многих, кто ставит себе задачи по исследованию «экзотических» языков в местах, где проживают их носители. Главные трудности Эверетта состояли не в этом, а в тех интеллектуальных метаморфозах, которые ему пришлось над собой произвести.

Первая из этих метаморфоз была связана с постепенным, но в конечном счете радикальным отказом от христианского фундаментализма, типичного для американских миссионеров-лингвистов. Эверетт буквально по капле выдавливал из себя протестантафундаменталиста, цель которого - «убедить счастливое, всем довольное племя в том, что они - заблудшие овцы и нуждаются в Иисусе Христе, чтобы спасти душу, каждый свою» (там же, с. 288). Подытоживая эту метаморфозу, Эверетт пишет: «Я же отдал то, что не мог удержать, - свою веру, чтобы обрести то, чего уже не лишусь, - свободу от того, что Томас Джефферсон назвал „тиранией чужого ума“, то есть от следования авторитетам в ущерб собственному разумению» (с. 293). Меня заинтересовало выражение «тирания чужого ума», использованное в русском переводе, и я обратился к английскому оригиналу. Исходный фрагмент звучит так: «I have given up what I could not keep, my faith, to gain what I cannot lose, freedom from what Thomas Jefferson called 'tyranny of the mind' - following outside authorities rather than one's own reason» (Everett, 2010, p. 272). Таким образом, эпитет «чужой» был для ясности добавлен переводчиком. Выяснилось, далее, что изначальное выражение Джефферсона также отличалось от цитаты Эверетта: «I have sworn upon the altar of God eternal hostility against every form of tyranny over the mind of man» (Jefferson, 1926, p.111-112). То есть у Джефферсона речь шла не о тирании ума, а о тира- 
нии над умом человека. Тем не менее вариант, который волею судеб получился в русском переводе книги Эверетта, удачно подходит для целей настоящей статьи, и поэтому именно он выбран в качестве заголовка. Как раз здесь мы и перейдем ко второй метаморфозе, которую осуществил над собой Дэниел Эверетт.

В ходе лингвистического образования, полученного Эвереттом, его способ мышления был сформирован генеративизмом - направлением, которое уже в течение многих десятилетий доминирует в лингвистике США и некоторых других стран (см. Фундаментальные направления..., 1997). Автор настоящей статьи отнюдь не является сторонником этого направления, предпочитая совсем иные научные приоритеты (см. статью данного автора и В.А. Плунгяна в вышеупомянутом сборнике). Полемика с генеративизмом совершенно не входит в задачи настоящей статьи. Достаточно лишь упомянуть, что генеративизм делает упор на универсальную грамматику, еще с 1950-х гг. предполагая, что базовые грамматические принципы всех языков в целом идентичны, поскольку являются врожденными. Неудивительно, что столкновение этой теории с данными неевропейских «экзотических» языков нередко озадачивало генеративистов.

Реакции на такое положение дел бывали разными. Чаще всего действовали по принципу: «если факты противоречат теории, тем хуже для фактов»; например, моделировались различные уровни деривации, на которых исследуемый язык уже оказывался достаточно похож на английский. Но бывало и иначе. Так, Кеннет Хэйл в свое время предложил улучшить теорию и различать конфигурационные языки и неконфигурационные, такие как австралийский язык валбири (Hale, 1983). Некоторые немногочисленные лингвисты с генеративным бэкграундом, встречаясь с неожиданными языками, проявляющими непослушание по отношению к теории, делали иной вывод - о том, что теорию спасти невозможно и под давлением фактов нужно перейти к совсем иной теории. Именно этот вывод сделал для себя Эверетт, в какой-то момент обнаружив, что генеративная теория не «налезает» на данные языка пираха(н)․ Отказ от генеративизма был для Эверетта не менее болезненным, чем отказ от протестантского фундаментализма. Здесь надо учитывать еще и социально-психологическую обстановку. Гене-

\footnotetext{
1 Вероятно, чуть более удачна русская репрезентация названия этого языка в виде пирахан (см., например, Иванов 2005; Д. Эверетт, личное обсуждение русской репрезентации). Этот вариант отражает назализацию конечного гласного в португальском названии pirahã, которое представляет собой некий искаженный вариант самоназвания - híaitíihí 'прямой, нормальный' (в свою очередь, содержащего высокий тон на конечном гласном $)-($ Д. Эверетт, личное сообщение; Эверетт, 2016, с. 319). Однако транслитерация названий языков с латиницы на кириллицу представляет собой запутанный вопрос, который пока совершенно не стандартизован. К тому же попытка передать средствами русской графики все особенности произнесения в языке-источнике в любом случае не может быть реализована идеально. Поэтому я считаю вполне допустимым и вариант пираха, в котором просто игнорируется диакритика, а число букв совпадает с португальским и английским наименованиями. В данной статье я использую именно этот вариант - вслед за выбором, который был сделан переводчиком книги. Следует также отметить, что это название обычно произносится с ударением на последнем слоге. Название применяется для обозначения не только языка, но и говорящего на нем племени.
}

ративизм представляет собой могущественную группировку в американской лингвистике, и диссидентство в ней отнюдь не поощряется. Бывшие коллеги по генеративному лагерю обрушились на Эверетта с яростной критикой, накал которой напоминает аналогичное неприятие со стороны коллег-миссионеров. Стойкость Эверетта по отношению к этой критике невольно вызывает уважение. В нем есть что-то от Прометея, который, как формулирует Большая советская энциклопедия, «бросает смелый вызов Зевсу и готов, невзирая на страшные муки, отстаивать свою правоту» (Ярхо, 2012, с. 76).

Представляется, однако, что Эверетт недовыдавил из себя генеративиста. В его представлениях о человеческом языке осталось слишком много от этой парадигмы, в которой изначально было сформировано его мышление. Я постараюсь показать, что от этой «тирании чужого ума» и происходят многие проблемы, с которыми Эверетт столкнулся при описании пираха, а также и многие сенсационные новости, которые он сообщил об этом языке лингвистическому сообществу.

Дальнейшее изложение строится следующим образом. В первой части статьи я рассмотрю несколько тезисов Эверетта относительно пираха, которые не кажутся достаточно убедительными. Во второй же части я перейду к некоторым другим его находкам, которые выглядят интересно. В ходе этого анализа я буду иногда обращаться к материалу знакомых мне атабаскских языков, так же как и пираха распространенных в Новом Свете, хотя и совсем в другой его части - на северо-западе Северной Америки.

\section{Не вполне убедительные тезисы}

\section{Принцип непосредственности восприятия}

В качестве основополагающей характеристики языка пираха Д. Эверетт выдвигает принцип непосредственности восприятия (или опыта), согласно которому «повествовательные предложения языка пираха содержат только утверждения, непосредственно связанные с моментом речи, о фактах, либо пережитых самим говорящим, либо засвидетельствованных кем-либо, кого говорящий застал в живых» (Эверетт, 2016, с. 143). Меня немного удивило, что Эверетт не ссылается при этом на Чарльза Хоккетта, который в свое время ввел широко известный термин displacement ${ }^{2}-$ перемещаемость, обозначающий как раз то же самое явление. Согласно Хоккетту, «языковые сигналы часто являются перемещаемыми: мы говорим о вещах, которых нет вокруг нас» (Hockett, 1960, p.354-355). Хоккетт рассматривал это свойство человеческого языка как универсальное и включил его в число важнейших характеристик языка (Hockett, 1960, p. 579).

Целый ряд фактов, которые сам Эверетт упоминает в разных местах книги, заставляет усомниться в том, что индейцы пираха неспособны думать или говорить о вещах, находящихся за пределами «здесь и сейчас». Так, на с. 32 говорится о том, что женщины строили планы на день - иными словами, представляли себе

2 Само это слово появляется в книге Эверетта на с.222, но в ином, генеративном, смысле. 
ситуации, которые еще не реализовались. На с. 77 - 84 рассказывается драматический эпизод, в котором группа индейцев при подстрекательстве речного торговца задумали убить Эверетта и вынашивали это намерение в подробностях в течение некоторого времени. Опять же, для этого они должны были нарисовать, в том числе вербально, картинку будущего убийства и его последствий. Наконец, на с. 148 излагается такой случай: «Несколько индейцев, которые сидели и пили со мной кофе, спросили: „Эй, Дэн, а американцы умирают?“”. Очевидно, для того, чтобы задать такой вопрос, необходимо представить себе какой-то незнакомый мир, где живут люди другого типа, а также предположить, что в этом другом мире могут действовать иные биологические законы.

Вероятно, наблюдение Эверетта о том, что ментальная и вербальная практика пираха обычно не выходит за пределы «здесь и сейчас», основано на реальности. Но формулировка этого наблюдения в жестких черно-белых терминах, как если бы перемещения в мышлении и языке пираха вообще не существовало, представляет собой явное преувеличение. Можно предположить, что индейцам пираха трудно рисовать отвлеченные ситуации по желанию исследователя. И подобная трудность с «перемещаемостью по указке» встречается при полевой работе и в других местах земного шара. Так, в докладе Ю. В. Мазуровой (2016) сообщалось, что информанты по языку химачальский пахари (север Индии) в ответ на просьбу перевести абстрактное предложение 'Мы работаем в полях' начинали говорить о своих полях, соседях и т.д.

\section{Отсутствие рекурсивных структур в синтаксисе}

В работах генеративистов так называемая рекурсия не раз выдвигалась как фундаментальное свойство человеческого языка. Рекурсия - это «явление, в соответствии с которым составляющая предложения доминирует над другим вхождением той же синтаксической категории» (Trask, 1993, p.229). Один из основных тезисов книги Эверетта состоит в следующем: в пираха нет рекурсии, а следовательно генеративная теория неверна. На это можно ответить две вещи. Вопервых, как показывает материал самого Эверетта, в пираха есть структуры, которые можно счесть рекурсивными. Во-вторых, неверно, что рекурсия является определяющей и эксклюзивной чертой синтаксиса, и выяснить это можно без обращения к данным пираха. Ниже я разовью оба эти утверждения.

В примерах текстов, которые приводит Эверетт, встречаются случаи цитации, например на с. 106: «Оии сказал: Описи здесь нет». Здесь цитируемая клауза вставлена в матричную клаузу, а это и есть типичный случай рекурсии.

На с. 257 Эверетт говорит о том, что в пираха нет сочинения предложений (точнее, клауз). Я затрудняюсь проинтерпретировать этот тезис, так как в устной речи отличить сочиненные клаузы от соположенных клауз, как правило, бывает нелегко или невозможно; во всяком случае, для этого надо применять специальную просодически ориентированную методику, чего Эверетт не делает. Но важнее другое. Если даже сложносочиненное предложение считается рекурсивной

\section{$1-2$

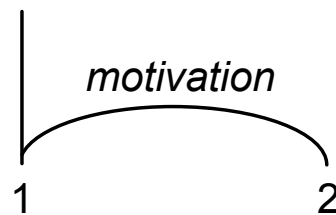 \\ don't sleep 2}

Рисунок 1. Представление двуклаузального заголовка книги в терминах Теории риторической структуры

структурой, то тем более такой структурой должна считаться полипредикативная конструкция с обстоятельственной связью между клаузами. Забавным образом, само название книги Эверетта «Don't sleep, there are snakes» является хорошим примером. Автор указывает, что индейцы пираха часто произносят это предложение (с. 18). Как правильно отметил А. Никулин в своем послесловии к книге, «отношение подчинения можно выделять не только на синтаксическом уровне, но и на более высоких уровнях, например на уровне глобальной структуры дискурса» (Никулин, 2016, с. 334), и это отношение можно описать в терминах Теории риторической структуры (Mann, Thompson, 1988). Если представить заголовок книги в виде графа, как это принято в данной теории, то мы получим такое представление, как на рисунке 1.

Таким образом, рекурсивные структуры в пираха не только существуют, но и используются в частотных оборотах речи. Между прочим, интересно задаться вопросом о том, что означает запятая в заголовке книги. И что означают различные пунктуационные знаки в текстовых примерах, приводимых на протяжении книги. Разумеется, пираха является бесписьменным языком, бытующим только в устной форме, и репрезентация его на письме представляет собой нетривиальную задачу, которую должен поставить перед собой исследователь любого такого языка (Jung, Himmelmann, 2011). По-видимому, пунктуационные знаки у Эверетта - некоторое косвенное отражение просодии (несегментной фонетики), но отражение это несистемное и интуитивное. Эверетт, подобно многим теоретикам-генеративистам, не отдает себе отчета в том, что устный и письменный модусы языка - это сильно различающиеся системы и что переносить представления о втором на первый некорректно. Даже само понятие «предложение», которое Эверетт постоянно использует, для устной речи может быть определено осмысленно лишь на основе просодических критериев (Кибрик, 2008).

Согласно Эверетту, в пираха не встречаются определительные придаточные. Но проблема в том, что они вообще редко встречаются в устной речи. Предложение типа Человек, который поймал рыбу, находится в доме (Эверетт, 2016, с. 245) всегда можно перифразировать как простую конкатенацию клауз: Человек поймал рыбу. Сейчас он находится в доме. В свое время я проводил исследование младописьменного языка навахо (атабаскская семья), на материале которого было много работ по структуре определительных придаточных. Я сравнил устные и письменные рассказы одного 
и того же рассказчика и обнаружил, что в устном варианте этот синтаксический прием использовался в три с половиной раза реже (Кибрик, 2009). При этом надо учесть, что грамотный носитель навахо, с которым я работал, мог проявлять синтаксическую интерференцию со стороны английского языка, так что в более чистой ситуации использование определительных придаточных, возможно, было бы еще реже. Пираха не владеют никаким языком, кроме своего родного, поэтому в их случае такая интерференция маловероятна. Нельзя исключить, что в случае превращения пираха в письменный язык и распространения двуязычия они могли бы использовать какие-то ресурсы своего языка для выработки конструкции, сравнимой с определительным придаточным.

Эверетт также говорит об отсутствии рекурсии и в более простых конструкциях - в посессивных именных группах. Точнее, простая рекурсия (конструкция типа кончик хвоста) бывает, а проблемы возникают с трехчленными конструкциями - пираха не могут сказать собаки хвоста кончик плохой (Эверетт, 2016, c. 255). Но такие конструкции в три и более этажей вообще нетипичны. Неслучайно в шуточных имитациях военного способа говорить используются именно такие конструкции, непереносимые для обычного человека: кнопка ручки крышки люка башни танка. Скорее всего, такие многоэтажные подчинительные конструкции нарушают не синтаксические принципы, а принципы когнитивной обработки в реальном времени. У. Чейф сформулировал ограничение одного нового понятия (one new idea constraint), согласно которому в одном кванте устной речи обычно не бывает более одного элемента новой (ранее не активированной) информации (Chafe, 1994). Фразы типа собаки хвоста кончик плохой нарушают это ограничение, поэтому пираха, не привычные к экспериментальным ситуациям и насилию над обычным узусом, и не признают такие фразы приемлемыми. Грамматические правила тут вообще ни при чем. То же касается и попыток Эверетта использовать более одного определения к существительному (с. 252). У. Чейф давно показал, что даже единичные атрибутивные прилагательные в четыре раза реже встречаются в английском устном дискурсе, нежели в письменном (Chafe, 1982), а два определения представляют собой уже крайнюю экзотику; см. также сборник «Разговорная речь в системе функциональных стилей современного русского литературного языка» (Сиротинина и др., 2003) об аналогичных явлениях в русском языке.

В целом многое из того, что Эверетт принимает за синтаксические ограничения, на самом деле является результатом когнитивных ограничений на употребление в устном дискурсе. С другой стороны, зачастую то, что он рассматривает как позитивные характеристики синтаксиса, также оказывается следствием более общих свойств дискурса и мышления. Временами кажется, что Эверетт довольно близко подходит к пониманию того, что в пираха рекурсия широко распространена в дискурсивных структурах (ср. Эверетт, 2016, c. 249). Одни и те же типы семантических отношений встречаются между дискурсивными единицами самого разного объема (этот факт хорошо описыва- ется в терминах упомянутой выше Теории риторической структуры). Фактически многие синтаксические структуры могут рассматриваться как частный случай дискурсивных структур. В устной речи рекурсия проявляется слабо как раз в синтаксисе, который предстает в виде слабооформленных связей между клаузами. В этом смысле синтаксис устной речи сильно отличается от синтаксиса подготовленного письменного текста (ср. Дронов, 2016, с. 323; статья С. А. Бурлак в настоящем выпуске журнала). Далее, рекурсия характерна не только для языка, но и для невербального человеческого мышления - ср. пример Эверетта из Г. Саймона на c. 251 - 252, в котором речь идет о процедуре сборки часов. Более того, рекурсивные структуры есть в природе (фрактальные явления, такие как лист папоротника), так что выдвигать рекурсию как эксклюзивное человеческое свойство вообще странно.

К сожалению, в вопросе о рекурсии Эверетт во многом остался в плену генеративных представлений. Дефолтные ожидания о том, каким должен быть человеческий язык, были сформированы его образованием. Если таких ожиданий не иметь, то факты языка пираха перестают быть столь сенсационными.

Понятие рекурсии полезно как эмпирическое наблюдение, но не имеет никакого определяющего значения для языка и тем более для грамматики. Относительная редкость рекурсивных структур в синтаксисе пираха является следствием устного и нестандартизированного характера этого языка.

\section{Отсутствие фатического общения}

Согласно Эверетту, у индейцев пираха отсутствует «„фатическая коммуникация“, то есть общение с целью поддержать социальные и межличностные связи, выразить уважение к собеседнику <...>. Выражения вроде „здравствуйте“, „до свидания“, „как дела?“, „извините“, „пожалуйста“, „спасибо“» (Эверетт, 2016, с.31). Вероятно, этот вывод основан на меньшей частотности подобных случаев в коммуникативной практике пираха, однако в книге есть немало примеров, показывающих, что само это явление на самом деле имеет место.

Так, пытаясь предотвратить агрессивные намерения индейцев, автор, явно уже хорошо освоивший их язык, вошел к ним в дом, «старательно проговаривая <...> на языке пираха: „Привет, друзья, как поживаете?“» (там же, с.79). В завершении того же эпизода с попыткой убить Эверетта: «К вечеру, проспавшись, мужчины племени пришли к нам извиняться» (с. 82). Позже автор решил обсудить произошедшие события с одним из индейцев: «Эй, скажи собакам не лаять на меня! - прокричал я ему, как принято у пираха, когда приходишь в гости» (там же). Наконец, заголовок книги опять же является иллюстрацией фатического общения:

«Уходя из моей хижины к себе спать, индейцы пираха прощаются со мной по-разному. Иногда они просто говорят: „Ну, я пошел“. Но часто они произносят другую фразу, которая сначала казалась мне странной, но со временем стала одной из самых любимых. Они говорят: „Не спи - кругом змеи!“» (Эверетт, 2016, с. 18). 


\section{Семантическое расширение терминов родства}

Эверетт обнаружил в языке пираха всего лишь пять терминов родства - один для всех старших родственников, один для людей своего поколения и три для младших (среди них есть два термина, различающих пол ребенка). Как справедливо отмечает Эверетт (c. 101), эта система очень простая и является одной из минимальных. Это очевидно на фоне типологических работ о существующих в языках системах терминов родства (см. например, Jonsson, 2001). Помимо количественных характеристик этой системы, Эверетт отмечает также широкую полисемию терминов родства. Особенно удивил его следующий термин: «baíxi отец, мать, дед или бабка, или даже просто кто-то, кому вы хотите выказать почтение в момент речи или вообще» (Эверетт, 2016, с. 101). В принципе, в таком расширении терминов родства нет ничего особенно необычного. Так, почтительные употребления терминов родства характерны для многих языков Юго-восточной Азии (например, вьетнамского, см. Daley, 1998). Да и в русском языке слова типа отеи, или бабуля часто используются в непрямых контекстах, когда говорящий стремится выразить уважение к адресату. Таким образом, система пираха действительно экстремальна в своем минимализме, однако пограничная семантика терминов родства - довольно обычное явление.

\section{Отсутствие дизъюнкции}

Эверетт отметил отсутствие в пираха вербальных средств, выражающих идею дизъюнкции. Он связал это наблюдение с более общими особенностями, усматриваемыми им в языке и культуре пираха: «Ограничение, налагаемое принципом непосредственности опыта на рекурсию, позволяет предсказать отсутствие дизъюнкции» (Эверетт, 2016, с.257). Не комментируя эту логическую связку, отмечу, что отсутствие дизъюнкции в принципе можно объяснить значительно проще.

В 2001 году я собирал сведения для статьи о верхнекускоквимском языке, которая предназначалась в сборник по типологии сочинения (Kibrik, 2004). Я достаточно быстро разобрался со средствами выражения конъюнкции, но испытал большие трудности при выяснении того, как в этом языке можно выразить идею дизъюнкции. Мне не удалось найти примеров в имеющихся собранных текстах. (Кроме одного случая, где носитель употребил дизъюнктивный союз $o$, который представляет собой переключение кода на английский - это просто англ. or 'или'.) Я обратился к методу элицитации, то есть квазиэкспериментального перевода с языка-посредника на изучаемый язык. Когда я в очередной раз мучил информанта вопросами типа: «А как по-вашему сказать „Ты хочешь чаю или кофе?"”, мой замечательный информант Уилли Петруска изрек: «They did not offer us choice in the old days» 'В старину выбора нам не предлагали'. Это не просто комический эпизод, в ответе Уилли содержится глубокий смысл. Когда объективные внешние обстоятельства жизни не провоцируют частотного выбора между возможными опциями или альтернативами (что и составляет прагматическую основу дизъюнкции, сp. Zimmermann, 2000), то соответствующее значение не рутинизируется в языке, а единицы типа дизъюнктивного союза могут и не существовать в лексиконе носителей.

Если все же потребность выразить идею выбора альтернативы окказионально возникает, то для этого можно прибегнуть к конъюнкции, точнее конкатенации. Уилли Петруска в конце концов сдался: на худой конец можно сказать «Чаю хочешь? Кофе хочешь?». Несмотря на то, что природные обстоятельства жизни в Амазонии намного более благоприятны и менее суровы, нежели в приполярной Аляске, вполне возможно, что одновременное рассмотрение альтернатив и выбор между ними в обществе пираха так же нетипичны, как и у верхнекускоквимцев. Несомненно, есть потребность в кросс-языковом исследовании, которое показало бы, насколько часто языки не располагают конвенциональными средствами выражения дизъюнкции.

\section{Интересные находки}

\section{Отсутствие числительных и неумение считать}

Как пишет Эверетт, «у индейцев пираха нет слов для обозначения числа и нет никакого счета» (Эверетт, 2016, с. 130; ср. также Иванов, 2005). Действительно, язык пираха по-видимому является экстремальным в этом отношении. В работе Б. Комри (Comrie, 2013) пираха отнесен к числу языков с «ограниченными» системами числительных, не выходящих за пределы числа 'двадцать'. Таких языков оказалось 20 из 196, включенных в выборку Комри. Среди этих языков пираха (опять же со ссылкой на данные Эверетта) оказался самым бедным языком. Как отмечается в другой работе Комри (Comrie, n.d.), «носители языков с ограниченными системами, таких как австралийские языки, традиционно не занимались счетом. Количество сущностей оценивалось при помощи „субитации“, то есть немедленного опознания числа, что возможно примерно до пяти штук».

Согласно Комри (Comrie, 2013), ограниченные системы представлены главным образом в Амазонии и в Австралии. Но не только. В верхнекускоквимском языке большинство носителей не знает и не употребляет числительных за пределами четырех (или даже трех). Интересно, однако, что верхнекускоквимцам традиционно было необходимо вести достаточно сложные подсчеты. Примерно до середины XX века представители этого небольшого народа были практически одноязычными и вряд ли знали английские числительные. Тем не менее это не мешало таежным охотникам-верхнекускоквимцам считать шкурки пушных животных (десятками и сотнями), выручаемые за них доллары, имеющиеся патроны и т.д.; эти умения были критически важны для их выживания. Боюсь, что науке неизвестно, как они это делали ${ }^{3}$. Возможно, они обладали

\footnotetext{
3 В книге С. Юнга (Young, 1915, p. 81) приводится описание того, как проводилась первая перепись индейцев в юго-восточной Аляске: главы семейств сдавали семена фасоли, соответственно числу домочадцев: коричневые обозначали мужчин, белые - женщин, мелкие - детей. Очевидно, индейцы, которым переписчики поручили эту операцию, могли поштучно соотносить каждую фасолину с конкретным человеком - и тем самым получать суммарное число.
} 
способностью субитации, кардинально превышающей небольшие числа вроде пяти. Но в любом случае необходимо признать, что люди в состоянии реализовывать числовую когницию без использования числительных как вербальных средств. (Отмечу, что противоположная точка зрения высказывается в статье Калеба Эверетта (Everett C., 2013)).

В этом контексте действительно удивительно, что пираха, по данным Эверетта, не в состоянии понять идею счета. Несмотря на усиленные уроки, которые Эверетт и его жена проводили среди индейцев, «никто не научился складывать три плюс один или даже один плюс один» (Эверетт, 2016, с. 131). Я хотел бы подчеркнуть, что этот факт не связан напрямую с отсутствием числительных и указывает на некоторую специфическую когнитивную особенность индейцев пираха. Таким образом, отсутствие (или слабая выраженность, ср. обсуждение в Иванов, 2005) даже самых низких числительных в пираха не столь уж уникально, а вот неспособность индейцев пираха понять идею счета представляется по-настоящему необычной. Впрочем, на с. 235 Эверетт пишет: «Если в языке пираха нет числительных, это отнюдь не значит, что его носители не умеют считать (например, по пальцам рук и ног)». Я точно не знаю, как согласовать это утверждение с раннее процитированным о том, что «у индейцев пираха <...> нет никакого счета» (с. 130).

\section{Чувство превосходства}

Наука о языке, как она сложилась в течение XX века, исходила из некого идеального представления о человеческих языках, согласно которому язык «принадлежит» гомогенному сообществу носителей и имеет четкие границы. В настоящее время становится все более очевидно, что эта идеализация слишком далека от реальности. Среди людей широко распространено двуи многоязычие, при котором языки, одновременно населяющие мозг носителя, взаимодействуют между собой. Даже те лингвисты, которые рассматривают языки как структурные сущности, все больше интересуются языковыми контактами. Тема языковых контактов постепенно выходит на первый план в сегодняшней лингвистике. Лексические и грамматические заимствования, переключение и смешение кодов, нечеткость границ языка - все это не периферия, а самый центр реалистической теории языка.

Интересным образом, пираха как раз представляет собой довольно редкий случай языка, близкий к идеальному, лабораторному представлению классической лингвистики. Дело в том, что этот язык распространен в небольшом сообществе, довольно однородном, практически одноязычном и закрытом для внешних контактных влияний. Объяснение этому факту, предлагаемое Эвереттом, весьма любопытно:

«Изоляция пираха вызвана ощущением собственного превосходства и презрением к прочим культурам. Они не считают себя ниже других оттого, что у них нет чего-либо, имеющегося в других языках и культурах, наоборот, они считают собственный образ жизни лучшим из возможных. Они совершенно не желают перенимать чужие ценности, поэтому культурные и языковые заимствования почти не просачиваются в пираха» (Эверетт, 2016, с. 263).

Эту культурную особенность племени пираха можно назвать чувством превосходства, а можно высокой степенью ксенофобии (снимая отрицательные коннотации этого слова). Ксенофобия - это не бинарный, а континуальный параметр, та или иная степень ксенофобии, вероятно, имеется у любой этнической группы, и это предпосылка сохранения этноса. Я полагаю, что степень ксенофобии является социолингвистическим параметром, влияющим на различные языковые характеристики. В первую очередь - на склонность к заимствованиям. Так, например, атабаскские народы (и их языки) характеризуются минимальной склонностью к лексическим и грамматическим заимствованиям, и это коррелирует с высокой степенью ксенофобии как культурной характеристикой атабасков. Например, навахо, ставшие самым крупным и наименее угрожаемым народом/языком Северной Америки (включая в это понятие США и Канаду), не имеют в своем языке почти никаких заимствований из других индейских языков, хотя неизбежно должны были контактировать со множеством племен, говорящих на языках разных семей.

Очевидно, для пираха также характерно отсутствие заимствований, а также отсутствие двуязычия, несмотря на контакты с другими народами и языками. Особенно удивительно то, что пираха практически не знают португальского языка, хотя контакты с носителями этого доминирующего языка длятся много столетий. Несомненно, высокая степень ксенофобии способствовала выживанию этого очень небольшого этноса в контексте не всегда благоприятных внешних условий.

\section{Теория относительности}

Подобно ряду других языков, в том числе северно-атабаскских, пространственная ориентация в пираха ориентирована на течение реки - источника жизни племени. В этом языке говорят «поверни вверх по реке» и даже "рука находится вверх по реке» (а не «поверни направо» или «правая рука») (Эверетт, 2016, c. 232 - 233). Эверетт делает вывод, что «язык заставляет пираха осмыслять мир иначе, чем мы» (там же, с. 235). В данном случае можно было бы поспорить, где здесь курица, а где яйцо (ср. статью М. А. Кронгауза в данном выпуске), однако сейчас для меня важнее другой поворот мысли Эверетта.

Обсуждая гипотезу языковой относительности Сепира-Уорфа, Эверетт пишет:

«Уорф даже утверждал, что западная наука в целом является следствием грамматических ограничений в европейских языках. Может ли быть так, что априорные категории морали в философии Канта на самом деле артефакт, вызванный дистрибуцией существительных и глаголов в немецком языке? Может ли оказаться, что теория относительности Эйнштейна - тоже?» (с. 236).

Я полагаю, что в принципе так может быть, и идея Эверетта о том, что сама теория относительности яв- 
ляется относительной, интересна. Однако может быть и так, что в экзотических языках обнаруживаются предпосылки для теоретических идей, независимо сформулированных учеными вопреки свойствам их собственных языков. Покажу это на примере моего собственного исследования, посвященного концептуализации движения в атабаскских языках.

Так, в верхнекускоквимском языке глаголы инициированного агенсом движения являются каузативами от глаголов самопроизвольного движения (например, ‘бросать' буквально значит 'заставлять двигаться'). Это совершенно обычное явление, встречающееся во многих языках мира. Необычно другое. Можно было бы ожидать, что глаголы транспортировки, например 'нести', тоже окажутся каузативами от глаголов самопроизвольного движения: ведь когда агенс несет весло или камень, он заставляет его переместиться из точки А в точку Б. Однако в верхнекускоквимском языке глаголы транспортировки родственны не глаголам самопроизвольного движения, а глаголам пребывания в покое, означающим 'лежать, находиться'. Это связано с разной системой отсчета, используемой в глаголах инициированного агенсом движения и в глаголах транспортировки. В первом случае (глаголы типа 'бросать') пациенс имеет собственную внутреннюю систему отсчета, а во втором случае (глаголы типа 'нести') - нет. Во втором случае несомый объект (пациенс) находится в системе отсчета агенса. $X$ несет $A$ буквально значит 'А находится в состоянии покоя относительно системы отсчета движущегося X’. C древних времен, задолго до Галилея и Эйнштейна, атабаски знали: движение различно в зависимости от выбора системы отсчета. (См. подробнее Kibrik, 2017.)

Этот вывод может считаться уорфианским лишь в самом широком смысле слова. Фактически носители атабаскских языков были хорошо подготовлены для создания теории относительности, а носители европейских языков - нет. Теория относительности, тем не менее, была придумана именно Эйнштейном, хотя таких хороших предпосылок, как верхнекускоквимский, немецкий язык для этого не давал. С моей точки зрения, уорфианство в широком смысле - это правильное и интересное направление мысли, но пользоваться им надо аккуратно. Особенности языков лишь создают предпосылки для тех или иных научных идей, но не предопределяют их. Замечу, что от вульгаризации уорфианства предостерегает и сам Эверетт, говоря, что не следует «злоупотреблять идеей о том, что язык определяет мышление» (Эверетт, 2016, с. 235).

\section{Заключение}

Если обобщить то, что Д. Эверетт писал в разные годы о пираха, и абстрагироваться от деталей, то можно было бы сказать, как булгаковский Воланд: чего ни хватишься, ничего нет. В репрезентации Эверетта это гораздо более простая (или бедная) система, в которой отсутствуют многие явления, которые мы по умолчанию предполагаем в любом языке. По этому поводу можно высказать два комментария.
Во-первых, как было показано выше, несколько сенсационные сообщения об отсутствии того или иного явления (рекурсия, фатическое общение) представляются отчасти преувеличенными. С другой стороны, на некоторой предполагаемой (но никем пока не эксплицированной) шкале обобщенной языковой сложности пираха действительно предстает языком, близким к полюсу большей простоты. Но можно ли это качество приписать самому языку, как это обычно склонны делать генеративисты и, вслед за ними, часто и Эверетт? Скорее всего, эта относительная простота является результатом тех или иных социальных явлений. Вообще роль социолингвистических процессов пока сильно недооценена в теории языка. Возможно, в предыстории языка и народа пираха есть какие-то события типа языкового сдвига, которые могли привести к уменьшению языковой сложности (эта или сходная мысль была высказана А.В. Дыбо на круглом столе по книге Эверетта, который состоялся в Институте языкознания РАН 21 февраля 2017 года и материалы которого лежат в основе данного выпуска).

Во-вторых, некоторые явления простоты, приписываемые Эвереттом грамматике пираха, на самом деле являются обычными явлениями устной речи. Например, рекурсии в синтаксисе устной речи на любом языке гораздо меньше, чем в письменной. Нужно еще учитывать, что в языках с существенной письменной традицией синтаксические конструкции письменной речи могут в какой-то мере заимствоваться в устную речь. Более того, от этого не ограждены даже младописьменные или бесписьменные языки, поскольку их носители могут быть знакомы с синтаксисом какого-либо доминирующего языка с письменной традицией. В этом смысле индейцы пираха, с их высоким уровнем ксенофобии и одноязычием, представляют собой особенно чистый случай. Их устная речь совсем не подвержена влиянию каких-либо моделей письменного синтаксиса. Вероятно, именно поэтому в устном синтаксисе пираха рекурсии еще меньше, чем в других языках. Таким образом, Эверетт пытается опровергнуть генеративизм, во многом оставаясь в системе его презумпций. Это и есть «тирания чужого ума», обозначенная в заголовке данной статьи. Разобраться в наблюдаемых явлениях пираха было бы гораздо проще на основании литературы о различиях устной и письменной речи, таких как исследование У. Чейфа (Chafe, 1982). Как писал Владимир Высоцкий, «Если в жарком бою испытал, что почем, / Значит, нужные книги ты в детстве читал».

В завершение упомяну понятие «WEIRD societies», предложенное в статье Дж. Хенриха с коллегами (Henrich et al., 2010). WEIRD - остроумная аббревиатура списка характеристик ряда человеческих обществ: Western, Educated, Industrialized, Rich, Democratic. Как справедливо указывают авторы статьи, ориентация на представителей именно этих обществ привели к системному перекосу в психологических исследованиях. При том, что эти общества «относятся к числу наименее репрезентативных популяций, которые вообще можно найти, занимаясь обобщениями относительно человечества» (Henrich et al., 2010, p.61). (В некотором смысле авторы этой работы солидаризируются с пираха, которые считают белых людей - как, впрочем, и всех не-пираха - «кривого- 
ловыми».) Идея о WEIRD-языках была поддержана и лингвистами: А. Маджид и С. Левинсон отметили, что «WEIRD-языки ввели в заблуждение и нас», поскольку лингвисты «переносили допущения, основанные на английском или других хорошо знакомых языках, на прочие языки» (Majid, Levison, 2010, p.103). В качестве вариации идеи WEIRD Э. Даль (Dahl, 2015) предложил понятие LOL-языков (Literate, Official, and with Lots of users), обсуждая вопрос о том, насколько языки этого типа превалируют в используемых лингвистами типологических выборках, претендующих на репрезентативность по отношению ко всей совокупности языков мира.

Это напрямую связано с темой данной статьи. Если нам удастся освободиться от европоцентризма и постоянного уклона в языки типа WEIRD/LOL, то многие явления пираха и прочих экзотических языков перестанут быть столь удивительными. А наоборот, окажутся совершенно естественными для большинства нормальных человеческих обществ, сформировавшихся вне письменной традиции, индустриализации и глобализации

\section{Литература}

Бурлак С.А. Язык пираха и разговорная речь // Российский журнал когнитивной науки. 2018. Т.5. № 1. C. 22-26.

Дронов П.С. Так ли уж несовместимы точки зрения Д. Эверетта и генеративистов? Послесловие // Д.Л. Эверетт. Не спи - кругом змеи! Быт и язык индейцев амазонских джунглей. М.: ЯСК, 2016. С. 309-324.

Иванов В.В. Типология языков бассейна Амазонки. II. Числительные и счет // Вопросы языкознания. 2005. Т. 5. C. $3-10$.

Кибрик А.А. Есть ли предложение в устной речи? // Фонетика и нефонетика. К 70-летию Сандро В. Кодзасова / Под ред. А.В. Архипова, Л.М. Захарова, А.А. Кибрика, и др. М.: ЯСК, 2008. С. 104-115.

Кибрик А.А. Модус, жанр и другие параметры классификации дискурсов // Вопросы языкознания. 2009. Т. 2. C. 3-21.

Кронгауз М.А. Дэниел Эверетт и Бенджамин Уорф: лингвистические и нелингвистические параллели // Российский журнал когнитивной науки. Т.5. № 1. С. 14-21.

Мазурова Ю.В. Полевые исследования в Индии: химачальские диалекты пахари // Доклад на открытом заседании Отдела типологии и ареальной лингвистики Института языкознания РАН, 27 декабря 2016. 2016.

Никулин А.В. Насколько необычен язык пираха? // Д.Л. Эверетт. Не спи - кругом змеи! Быт и язык индейцев амазонских джунглей. М.: ЯСК, 2016. С. 325 - 340.

Сиротинина О.Б., Столярова Э.А., Кузнецова Н.И., Кормилицына М.А., Богданова В.А., Ножкина Э.М. Разговорная речь в системе функциональных стилей современного русского литературного языка. М.: УРСС, 2003.

Эверетт Д. Л. Не спи - кругом змеи! Быт и язык индейцев амазонских джунглей. М: ЯСК, 2016.

Фундаментальнье направления современной американской тингвистики. Сборник обзоров / Под ред. А.А. Кибрика, И.М. Кобозевой, И.С.Секериной. М.: Издательство МГУ, 1997.

Ярхо В.Н. Прометей // Большая советская энциклопедия (БСЭ). 3-е изд. Советская энциклопедия, 1969/1978. С.76.
Chafe $W$. Integration and involvement in speaking, writing, and oral literature // Spoken and written language: Exploring orality and literacy / D. Tannen (Ed.). Norwood: Ablex, 1982. P. $35-54$.

Chafe W. Discourse, consciousness, and time. The flow and displacement of conscious experience in speaking and writing. Chicago: University of Chicago Press, 1994.

Comrie B. Numeral bases // The world atlas of language structures online / M.S. Dryer, M. Haspelmath (Eds.). Leipzig: Max Planck Institute for Evolutionary Anthropology, 2013. URL: http://wals.info/chapter/131.

Comrie B. Typology of numeral systems. N.d. URL: https:// mpi-lingweb.shh.mpg.de/numeral/TypNumCuhk 11ho.pdf (May 07, 2017).

Dahl Ö. How WEIRD are WALS languages? // Paper presented at the conference: Diversity linguistics: Retrospect and prospect. Max Planck Institute for Evolutionary Anthropology, 1-3 May 2015. Leipzig, Germany: 2015. URL: http://www.eva. mpg.de/fileadmin/content files/linguistics/conferences/2015diversity-linguistics/Dahl slides.pdf.

Daley K.A. Vietnamese classifiers in narrative texts. Arlington: University of Texas, 1998.

Everett $C$. Independent cross-cultural data reveal linguistic effects on basic numerical cognition // Language and Cognition. 2013. Vol.5. No.1. P. 99 - 104. doi:10.1515/langcog-2013-0005

Everett D. L. Don't sleep, there are snakes. Life and language in the Amazonian jungle. New York: Pantheon Books, 2010.

Hale $K$. Warlpiri and the grammar of non-configurational languages // Natural Language and Linguistic Theory. 1983. Vol.1. No.1. P.5 - 47. doi:10.1007/bf00210374

Henrich J., Heine S. J., Norenzayan A. The weirdest people in the world? // Behavioral and Brain Sciences. 2010. Vol.33. No.2 - 3 . P.61 - 83. doi:10.1017/s0140525x0999152x

Hockett C.F. A course in modern linguistics. New York: Macmillan, 1958.

Jefferson T. To Dr. Benjamin Rush. Monticello, September 23, 1800 // Jefferson, Thomas. The best letters of Thomas Jefferson / J.G. de Roulhac Hamilton (Ed.). Boston and New York: Houghton Mifflin Company, 1926. P.111-112.

Jonsson N. Kin terms in grammar // Language typology and language universals. An International handbook / M. Haspelmath, E. Koeig, W. Raible, W. Oesterreicher (Eds.). Berlin: de Gruyter, 2001. P. 1203 - 1214.

Jung D., Himmelmann N.P. Retelling data: Working on transcription // Documenting endangered languages: Achievements and perspectives / G.L.J. Haig, N. Nau, S. Schnell, C. Wegener (Eds.). Berlin: De Gruyter Mouton, 2011. P.201 - 220. Kibrik A.A. Coordination in Upper Kuskokwim Athabaskan // Coordinating constructions / M. Haspelmath (Ed.). Amsterdam: Benjamins, 2004. P.537-553. doi:10.1075/ tsl.58.26kib

Kibrik A.A. Conceptualization of movement in Upper Kuskokwim Athabaskan // Each venture a new beginning: Studies in honor of Laura A. Janda / A. Makarova, S. Dickey, D. Divjak (Eds.). Slavica Bloomington, 2017. P.127 - 138.

Majid A., Levinson S. C. WEIRD languages have misled us, too // Behavioral and Brain Sciences. 2010. Vol.33. No.2 - 3. P. 103. doi:10.1017/s0140525x1000018x

Mann W., Thompson S.A. Rhetorical structure theory: Toward a functional theory of text organization // Text Interdisciplinary Journal for the Study of Discourse. 1988. Vol.8. No.3. P.243 - 281. doi:10.1515/text.1.1988.8.3.243

Trask R. L. A dictionary of grammatical terms in linguistics. London: Routledge, 1993.

Young S. H. Alaska days with John Muir. New York: Fleming H. Revell Company, 1915.

Zimmermann E. Free choice disjunction and epistemic possibility // Natural Language Semantics. 2000. Vol.8. P.255-290. 


\title{
Tyranny of Another Mind
}

\author{
Andrej A. Kibrik
}

Institute of Linguistics RAS, Moscow, Russia;

M.V. Lomonosov Moscow State University, Moscow, Russia

\begin{abstract}
Daniel Everett's book recounts his complicated intellectual evolution, including his rejection of the generative approach towards language. Still, Everett's conceptual system involves a number of elements going back to his generative upbringing, which informs many of his claims regarding the uniqueness of Pirahã. Among his controversial claims, partly derived from Everett's background in generative linguistics, are the principle of immediate experience; the lack of recursion, phatic communication, and disjunction; and the polysemy of kin terms. Everett's book contains a number of interesting observations that indeed portray Pirahã as a rather unusual language and culture. These include observations on the Pirahã people's inability to count, their feeling of cultural superiority, and relativity. In general, Everett's work contributes to the grappling with Eurocentrism that is still characteristic of many schools in linguistics.
\end{abstract}

Correspondence: Andrej A. Kibrik, aakibrik@gmail.com, Institute of Linguistics RAS, 1 B. Kislovskij per., 125009 Moscow, Russia

Keywords: history of ideas, theory of language, linguistic diversity, recursion, spoken language, numerical cognition

Copyright (C) 2018. Andrej A. Kibrik. This is an open-access article distributed under the terms of the Creative Commons Attribution License (CC BY), which permits unrestricted use, distribution, and reproduction in any medium, provided that the original author is credited and that the original publication in this journal is cited, in accordance with accepted academic practice.

Acknowledgements. Studies underlying this paper were conducted with the support of RFBR Grant \#17-06-00460. The author is grateful to Mira B. Bergelson and Olga V. Fedorova for useful discussions about this paper.

Received May 7, 2017, accepted February 28, 2018.

\section{References}

Burlak, S. (2018). Pirahã and spoken language. The Russian Journal of Cognitive Science, 5(1), 22-26.

Chafe, W. (1982). Integration and involvement in speaking, writing, and oral literature. In D. Tannen (Ed.), Spoken and written language: Exploring orality and literacy (pp. 35 - 54). Norwood: Ablex.

Chafe, W. (1994). Discourse, consciousness, and time. The flow and displacement of conscious experience in speaking and writing. Chicago: University of Chicago Press.

Comrie, B. (2013). Numeral bases. In M.S. Dryer, \& M. Haspelmath (Eds.), The world atlas of language structures onlineLeipzig: Max Planck Institute for Evolutionary Anthropology. Retrieved May 07, 2017 from http://wals.info/chapter/131.

Comrie, B. (n.d.) Typology of numeral systems. Retrieved May 07, 2017 from https://mpi-lingweb.shh.mpg.de/numeral/ TypNumCuhk 11ho.pdf.

Dahl, Ö. (2015). How WEIRD are WALS languages? Paper presented at Diversity Linguistics: Retrospect and Prospect conference, Max Planck Institute for Evolutionary Anthropology, 1-3 May 2015, Leipzig, Germany. Retrieved May 07, 2017 from http://www.eva.mpg.de/fileadmin/content files/ linguistics/conferences/2015-diversity-linguistics/Dahl slides.pdf.

Daley, K.A. (1998). Vietnamese classifiers in narrative texts. Arlington: University of Texas.

Dronov, P.S. (2016). Tak li uzh nesovmestimy tochki zreniya D. Everetta i generativistov? [Are Everett's and generativist perspectives so inconsistent? An afterword]. In Everett, D.
Ne spi - krugom zmei. Byt i yazyk indeitsev amazonskikh dzhunglei [Don't sleep, there are snakes: Life and language in the Amazonian Jungle] (P.S. Dronov, I.V. Mokin, E.N. Panov, Trans. into Russian) (pp.309-324). Moscow: LRC Publishers. (In Russian).

Everett, C. (2013). Independent cross-cultural data reveal linguistic effects on basic numerical cognition. Language and Cognition, 5(1), 99 - 104. doi:10.1515/langcog-2013-0005

Everett, D.L. (2010). Don't sleep, there are snakes. Life and language in the Amazonian jungle. New York: Pantheon Books.

Hale, K. (1983). Warlpiri and the grammar of non-configurational languages. Natural Language and Linguistic Theory, 1(1), 5- 47. doi:10.1007/bf00210374

Henrich, J., Heine, S. J., \& Norenzayan, A. (2010). The weirdest people in the world? Behavioral and Brain Sciences, 33(2-3), 61 -83. doi:10.1017/s0140525x0999152x

Hockett, C.F. (1958). A course in modern linguistics. New York: Macmillan.

Ivanov, V.V. (2005). Tipologiya yazykov basseina Amazonki. II. Chislitel'nye i schet [Typology of Amazonian languages. II. Numerals and counting]. Voprosy Jazykoznanija (Topics in the Study of Language), 5, 3 - 10. (In Russian).

Jefferson, T. (1926). To Dr. Benjamin Rush. Monticello, September 23, 1800. In J.G. de Roulhac Hamilton (Ed.), Jefferson, Thomas. The best letters of Thomas Jefferson (pp. 111-112). Boston and New York: Houghton Mifflin Company.

Jonsson, N. (2001). Kin terms in grammar. In M. Haspelmath, E. Koeig, W. Raible, \& W. Oesterreicher (Eds.), Language typology and language universals. An International handbook, Vol.2. (pp. 1203 - 1214). Berlin: de Gruyter. 
Jung, D., \& Himmelmann, N.P. (2011). Retelling data: Working on transcription. In G.L.J. Haig, N. Nau, S. Schnell, \& C. Wegener (Eds.), Documenting endangered languages: Achievements and perspectives (pp.201-220). Berlin: Mouton de Gruyter.

Kibrik, A.A. (2008). Est' li predlozhenie v ustnoi rechi? [Are there sentences in the spoken language?] In A.V. Arkhipov, L.M. Zakharov, A.A. Kibrik, \& et al. (Eds.), Fonetika i nefonetika. K 70-letiyu Sandro V. Kodzasova [Phonetics and nonphonetics. Paper collection in honor to Sandro V. Kodzasov's 70-th anniversary] (pp.104-115). Moscow: LRC Publishers. (In Russian).

Kibrik, A.A. (2004). Coordination in Upper Kuskokwim Athabaskan. In M. Haspelmath (Ed.), Coordinating constructions (pp.537-553). Amsterdam: Benjamins. doi:10.1075/ tsl.58.26kib

Kibrik, A.A. (2017). Conceptualization of movement in Upper Kuskokwim Athabaskan. In A. Makarova, S. Dickey, \& D. Divjak (Eds.), Each venture a new beginning: Studies in honor of Laura A. Janda (pp. 127 - 138). Slavica Bloomington.

Kibrik, A.A. (2009). Modus, zhanr i drugie parametry klassifikatsii diskursov [Modus, genre and other parameteres in classification of discourse]. Voprosy Jazykoznanija (Topics in the Study of Language), 2, 3-21. (In Russian).

Kibrik, A.A., Kobozeva, I.M., \& Sekerina, I.S. (Eds.). (1997). Fundamental'nye napravleniya sovremennoi amerikanskoi lingvistiki. Sbornik obzorov [Fundamental directions of modern American linguistics. A collection of reviews]. Moscow: MSU Publishing. (In Russian).

Krongauz, M. (2018). Daniel Everett and Benjamin Whorf: Linguistic and Non-linguistic Parallels. The Russian Journal of Cognitive Science, 5(1), 14-21.

Majid, A., \& Levinson, S.C. (2010). WEIRD languages have misled us, too. Behavioral and Brain Sciences, 33(2-3), 103 doi:10.1017/s0140525x1000018x
Mann, W., \& Thompson, S.A. (1988). Rhetorical structure theory: Toward a functional theory of text organization. Text Interdisciplinary Journal for the Study of Discourse, 8(3), 243 - 281. doi:10.1515/text.1.1988.8.3.243

Mazurova, Y.V. (2016). Polevye issledovaniya $v$ Indii: khimachal'skie dialekty Pakhari [Field work in India: Himachal dialects of Pakhari]. Paper presented at the open seminar of the Typology and Areal linguistics Department of the Institute of Linguistics of the Russian Academy of Sciences, December 27, 2016. (In Russian).

Nikulin, A.V. (2016). Naskolko neobychen yazyk pirakha? Posleslovie [How exceptional is piraha language? An afterword]. In D.L. Everett. Ne spi - krugom zmei! Byt i yazyk indeitsev amazonskikh dzhunglei [Don't sleep, there are snakes: Life and language in the Amazonian Jungle] (P.S. Dronov, I.V. Mokin, E.N. Panov, Trans. into Russian) (pp.325-340). Moscow: LRC Publishers. (In Russian).

Sirotinina, O.B., Stolyarova, E.A., Kuznetsova, N.I., Kormilitsyna, M.A., Bogdanova, V.A., \& Nozhkina, E.M. (2003). Razgovornaya rech' $v$ sisteme funktsional'nykh stilei sovremennogo russkogo literaturnogo yazyka [Spoken language in the system of functional styles of Modern Russian Standard Language]. Moscow: URSS. (In Russian).

Trask, R.L. (1993). A dictionary of grammatical terms in linguistics. London: Routledge.

Yarkho, V.N. (1969/1978). Prometei [Prometheus]. In Bolshaya sovetskaya entsiklopediya [Big Soviet Encyclopedia. 3rd Edition], Vol.21. (pp.76). Soviet Encyclopedia.

Young, S.H. (1915). Alaska days with John Muir. New York: Fleming H. Revell Company.

Zimmermann, E. (2000). Free choice disjunction and epistemic possibility. Natural Language Semantics, 8, 255 - 290. 


\title{
Риау индонезийский, пирахан: что дальше?
}

\section{Валерий Дмитриевич Соловьев}

Казанский федеральный университет, Казань, Россия

\begin{abstract}
Аннотация. Статья посвящена проблеме наличия рекурсии в языке пирахан. Выраженное в ряде публикаций мнение об отсутствии в этом языке рекурсии и, соответственно, явном противоречии с базовыми постулатами теорий Хомского, представляется ошибочным, основанным на ограниченном понимании рекурсии как сложных синтаксических конструкций. В статье рассматривается несколько видов языковых конструкций, которые можно трактовать как рекурсивные в более широком смысле, исходящем из математического понятия рекурсии. Показано, что свойственная мышлению рекурсивность может быть реализована и в таких конструкциях, а не только в традиционно понимаемой рекурсии. Пирахан использует для этих целей сочинительные конструкции. Приведены примеры других языков с аналогичными свойствами: ранее описанный риау индонезийский и пиджины. Интересный материал для анализа в свете рассматриваемой проблемы представляет также язык, которому удалось обучить обезьян, поскольку возможности по созданию длинных высказываний у обезьян ограничены.
\end{abstract}

Контактная информация: Валерий Дмитриевич Соловьев, maki.solovyev@mail.ru; 420101, Казань, a/я 93.

Ключевые слова: пирахан, рекурсия, генеративная грамматика Хомского, сочинительные конструкции, говорящие обезьяны

(c) 2018 Валерий Дмитриевич Соловьев. Данная статья доступна по лицензии Creative Commons "Attribution" («Атрибуция») 4.0. всемирная, согласно которой возможно неограниченное распространение и воспроизведение этой статьи на любых носителях при условии указания автора и ссылки на исходную публикацию статьи в данном журнале в соответствии с канонами научного цитирования.

Благодарности. Работа выполнена за счет средств субсидии, выделенной Казанскому федеральному университету для выполнения государственного задания в сфере научной деятельности, проект 34.5517.2017/6.7. Автор выражает благодарность анонимным рецензентам за многочисленные полезные советы, в значительной степени способствовавшие улучшению текста.

Статья поступила в редакцию 29 мая 2017 г. Принята в печать 23 марта 2018 г.

\section{Введение}

Книга Д. Эверетта (Everett, 2008), посвященная языку индейцев пираха (в дальнейшем этот язык будем называть пирахан, кажется, это название в русском языке уже устоялось), буквально всколыхнула лингвистический мир. Google на запрос об этой книге выдает более трех тысяч сайтов.

Язык пирахан привлек внимание целым рядом весьма любопытных и, возможно, уникальных свойств. Статьи о нем публиковались в таких престижных научных журналах, как Science (Gordon, 2004). Одним из ключевых моментов, вызвавших повышенный интерес именно к книге Д. Эверетта, является вопрос - есть ли в языке пирахан рекурсивные структуры?

Прежде всего, отметим, что понятие рекурсии первоначально возникло в математике для обозначения функций, которые определяют свое значение через обращение к себе самой с другими аргументами.
В лингвистике Хомский нашел (бесспорную) рекурсию во вложенных синтаксических конструкциях. Однако, вообще говоря, рекурсия трактуется шире. Вероятно, даже возникновение концепции натурального ряда чисел $1,2,3, \ldots$ связано с рекурсивной способностью нашего сознания применять одну и ту же операцию (в данном случае прибавление 1) к ранее построенному объекту (множеству чисел).

В рассматриваемой книге Д. Эверетта (2008/2016) показано, что пирахан не обладает механизмом вложенных подчиненных составляющих (clauses), и, как следствие, считается, что он не обладает рекурсивными структурами. Эта точка зрения нашла отражение уже даже в «Википедии», в статье о рекурсии. Важность вопроса связана с тем, что рекурсивность, согласно наиболее влиятельной современной лингвистической теории - теории Хомского, является ключевым свойством человеческих языков, отличающим их от коммуникативных систем животных. Как отмечает 
профессор лингвистики университета Осло Р. Тейл (Theil, 2016): «Pirahã is also perhaps the only language in the world that lacks a recursive structure... If Pirahã really does lack this, it could be curtains for Chomsky's system» ${ }^{\mathbf{}}$.

В данной статье мы рассматриваем круг вопросов, связанных с рекурсией. Можно ли, опираясь на данные Д. Эверетта, утверждать, что пирахан действительно не обладает рекурсией? Является ли он в этом аспекте единственным? Какими средствами рекурсия, свойственная мышлению, может быть выражена в языке? Является ли пирахан угрозой для теории Хомского? Наконец, есть ли рекурсивные структуры в «языке» обезьян, которых обучали человеческим языкам? В чем принципиальное отличие языков людей от «языка» этих обезьян?

\section{Виды рекурсии. Вложенные подчиненные и сочиненные составляющие}

Согласно Д. Эверетту (Everett, 2008), пирахан не имеет сложноподчиненных предложений с вложенными клаузами. Вместо «When I have finished fishing, I would like to speak with you» индейцы пираха скажут: «I finish fishing, I speak to you» (Everett, 2008). Здесь мы видим замену подчинительной конструкции на сочинительную.

Сразу отметим, что подобная стратегия широко представлена, например, и в русском языке. Можно сказать: Когда пожарю котлеть, поиграю с тобой. Но можно сказать и Пожарю котлеты и поиграю с тобой. Смысл сказанного при такой замене не теряется. Сходное мнение и примеры приведены в статье С.А. Бурлак «Язык пираха и разговорная речь» в этом же номере журнала.

В известном стихотворении Р. Бернса в переводе С. Маршака (Маршак, 1968) используется многократное вложение клауз:

Boт кот,

Который пугает и ловит синииу,

Которая часто ворует пшеничу,

Которая в темном чулане хранится

В доме,

Который построил Джек.

Однако понятно, что в реальной речи мы не пользуемся такими громоздкими конструкциями, носящими маргинальный, в данном случае шуточно-игровой, характер. При необходимости мы бы сказали что-то вроде:

Этот дом построил Джек, в его темном чулане хранится пшеница. Одна синица часто ее ворует, а кот пугает и ловит эту синицу.

Здесь опять-таки подчинительные конструкции заменяются на сочинительные без ущерба для смысла. Они могут быть и далее заменены на последовательность однотипных простых предложений, следующих одно за другим. Такая замена представляется нормальной, а не

1 Пирахан также, возможно, единственный в мире язык, где отсутствуют рекурсивные структуры... Если в языке пирахан их действительно нет, это может быть финалом для теории Хомского. исключительной стратегией. Отметим, что сочинительную конструкцию мы трактуем в этой статье в широком смысле: неважно, связываются ли отдельные ее части союзами или разделяются запятой, точкой с запятой или даже точкой (в устной речи - соответствующими интонационными средствами). То есть это просто последовательность однотипных элементов, расположенных один за другим.

Пирахан не обладает подчинительными конструкциями, но совершенно невозможно представить себе человеческие языки без сочинительных конструкций. Именно они обеспечивают представление последовательности мыслей в форме последовательности клауз. Вероятно, наличие сочинительных конструкций является абсолютной универсалией для человеческих языков. Их существование во всех языках настолько очевидно, что Дж. Гринберг даже не включил существование сочинительных конструкций в свой список универсалий (Greenberg, 1963).

Часто, в том числе в работах Д. Эверетта и его оппонентов по дискуссии в журнале Language (Everett, 2008; Nevins et al., 2009), только подчинительные конструкции рассматриваются как рекурсивные. Очевидно, это связано с жесткой привязкой к исходному определению рекурсии в ранних версиях генеративной грамматики и устоявшейся традицией. Тот факт, что сочинительные конструкции также могут выражать рекурсию и представлять в этом плане функциональный эквивалент вложенных подчинительных конструкций, почему-то выпадает из поля зрения.

Между тем в последней версии теории Хомского - минималистской программе (Chomsky, 1995) базовая синтаксическая операция 'merge' (сцепить) всего лишь рекурсивным образом нанизывает элементы один на другой. Н. Хомский пишет: «Язык - это рекурсивная процедура, которая генерирует бесконечное множество выражений» (Хомский, 2005, с. 128).

Как видим, в действительности не требуется, чтобы рекурсия выражалась именно в подчинительных отношениях. Принципиально важным по Хомскому является лишь сама возможность генерировать бесконечное множество выражений рекурсивным образом.

С математической точки зрения сочинительные конструкции, безусловно, являются рекурсивными. Опишем сочинение в виде программы на псевдокоде. Представим себе, что мы хотим выразить некую последовательность мыслей - обозначим ее в виде файла $h$. Выходом будет речь - файл $g$. В нижеследующей программе $x$ - это переменная, которой присваивается очередная мысль, $y$ - переменная, получающая своим значением звуковую форму мысли. Операция 'читать' считывает очередной элемент файла и переходит к следующему, если он есть в файле. EOF - конец файла.

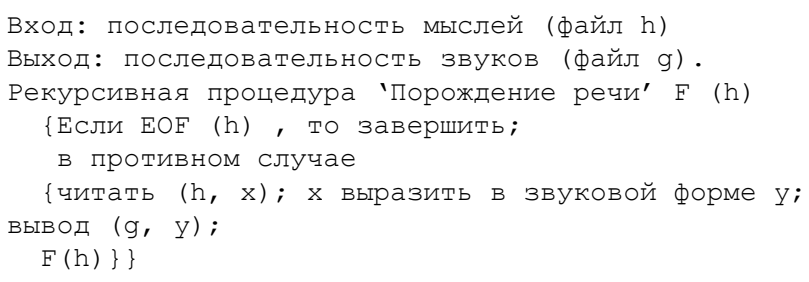

Здесь процедура $F$ обращается сама к себе - то есть является рекурсивной - и осуществляет преоб- 
разование последовательности мыслей в последовательность звуков.

Итак, отсутствие подчиненных клауз отнюдь не означает отсутствие рекурсии вообще, а лишь отсутствие рекурсии в одной из ее форм, на уровне синтаксиса. Остановимся еще на некоторых видах рекурсии. Мы здесь не будем касаться сложных случаев двойной рекурсии, известных в математике, но обсуждаемых и применительно к лингвистике (Лопатко, 2004).

Рекурсия в морфологии обычно не рассматривается. Действительно, в языках типа русского и английского ее обнаружить трудно. В работе С. Пинкера и Р. Джанкендорффа (2008) утверждается, что слоговая структура языка нерекурсивна. Но если обратиться к агглютинативным языкам, то мы ее обнаружим в них в явной форме. В работе Д. Сулейманова (2008) приведен такой пример из татарского языка: Татарчалаштыргалаштыручылардагыныкыларгамыни? Что означает «Разве тем, что принадлежит тому, что на тех, кто время от времени занимается татаризацией?» и имеет следующую структуру аффиксов:

Татар+ча+ла+штыр+гала+штыр+у+чы+лар+дагы +ныкы+лар+га+мыни.

Видно, что некоторые аффиксы (umыр, лар) употребляются двукратно и что семантическая структура этого предложения рекурсивна, так что здесь рекурсия присутствует в чистом виде. Хотя, разумеется, в реальной речи такие конструкции вряд ли встречаются, но и многократно вложенное подчинение, как в случае «Дома, который построил Джек», тоже не встречается в нормальных условиях.

Структура именной группы, естественно, тоже является рекурсивной, формируясь навешиванием на уже созданную именную группу очередного определения. Следует отметить, что и здесь при теоретической возможности навешивания неограниченного числа определений, например прилагательных, в реальности степень вложенности невелика. Максимальное число прилагательных в реальном примере, который мне удалось найти, - шесть: Казанский государственный академический русский Большой драматический театр имени В.И. Качалова. Возможно, это ограничение связано с объемом оперативной памяти.

К сожалению, нет данных по подобным видам сложных конструкций в пирахан. Чтобы установить, могут ли индейцы пираха оперировать ими, вероятно, нужно проводить специальные психолингвистические эксперименты. Отметим, что и в русском, и в других хорошо изученных языках глубина рекурсии, кроме сочинительных конструкций, в реальных текстах весьма ограничена. Настоящую продуктивность языку, возможность генерировать «бесконечное множество выражений», обеспечивает рекурсия сочинительных конструкций.

\section{Является ли пирахан единственным языком без рекурсии?}

Нет. Первый, сразу приходящий в голову пример пиджины. Возьмем для примера русско-китайский пиджин. Согласно Е. Перехвальской (2013), характерной чертой русско-китайского пиджина является «отсутствие сложных предложений, сочинительных и подчинительных союзов». Вот несколько типичных примеров (Пиджин):

(1) А мы таньше нада бы спрасил бы, а щаса исё забыла; галава бали, кости бали, я еле-еле ходит. «Меня раньше надо было спрашивать, а сейчас все забыла; голова болит, кости болят, я еле-еле хожу».

(2) Его сота рубли купеза давай; его хаохао-ды ю, дада-дь ю; полтора года таскай, ломай не могу; его замерзни мею.

«За нее торговцы 100 рублей предлагают; она очень хороша, большая; полтора года проносишь - не порвется; в ней не замерзнешь».

Как видим, отсутствие сочинительных союзов не мешает строить длинные предложения, в которых клаузы нанизываются рекурсивным образом на ранее сгенерированные предложения. Мы оставляем за скобками вопрос о членении устной речи на предложения, анализе соответствующих интонационных средств, что лежит далеко за пределами сферы интересов данной статьи. См. по этому вопросу (Коротаев, 2009; Nevins et al., 2009). В вышеприведенных примерах запятые и точки с запятой являются особенностями записи устной речи исследователями.

В русско-китайском пиджине нет сложноподчиненных предложений. Точнее говоря, нет признаков сложноподчиненных конструкций на уровне синтаксической структуры предложения. Характерные для сложноподчиненных конструкций связи - причинно-следственные и т.д. устанавливаются на уровне семантического анализа. Не исключено, что они маркируются некоей интонацией, то есть сложноподчиненные конструкции могут все же существовать, но на уровне «устного» синтаксиса. Насколько мне известно, исследования по данному вопросу не проводились.

Можно было бы предположить, что пиджины являются лишь какими-то «полуфабрикатами», заготовками, из которых затем формируются «настоящие» языки. Однако они являются человеческими языками, успешно выполняющими коммуникативные функции.

Приведем пример и «настоящего» языка, не пиджина, также без сложноподчиненных предложений. Это риау индонезийский, представленный Д. Гилом в (Gil, 1999) как «язык без грамматики» (в ее привычном понимании). Утверждается, что в нем нет частей речи, что это "pivotless language», то есть в нем отсутствуют первичные измерения: ролевое (актор, пациенс, и т.д.), коммуникативное (топик/коммент, данное/новое и т.д.), дейктическое (говорящий/слушающий, здесь/там и т.д.). Подробнее об этом см. работу А.Е. Кибрика (Kibrik, 1997).

Д. Гил посвятил изучению риау индонезийского много лет и написал много статей ${ }^{2}$. В статье «Syntactic categories, cross-linguistic variation and universal grammar» (Gil, 2000) он предложил теорию синтаксических категорий, показывающую место грамматики языка риау индонезийского по отношению к дру-

2 Список его публикаций можно найти по адресу http://mpi-survey3. shh.mpg.de/gil/CV.pdf 
гим языкам. Мы не имеем ни целей, ни возможностей сколько-нибудь подробно излагать теорию Д. Гила. Однако для нас важно его понимание сочинительных конструкций и рекурсии. Для объяснения этого введем основные определения его теории.

Д. Гил ввел два постулата парадигматического формирования категорий:

Начальная категория: $\mathrm{S}^{0}$

Операторы образования категорий:

i. Слеш: Для любых двух категорий X and Y, $\mathrm{X} / \mathrm{Y}$ - категория, называемая 'X слеш Y'.

ii. Ядро: Для любой категории $\mathrm{X}^{\mathrm{n}}, \mathrm{X}^{\mathrm{n}+1}-$ категория, называемая 'ядром категорией $\mathrm{X}^{\mathrm{n}}$ '.

А также два постулата синтагматической комбинации категорий:

a. Комбинация тождественности: $\mathrm{X} \leftrightarrow(\mathrm{X}, \mathrm{X}, \mathrm{X} \ldots)$

b. Слеш-комбинация: $\mathrm{X} \leftrightarrow(\mathrm{Y}, \mathrm{X} / \mathrm{Y}, \mathrm{X} / \mathrm{Y}$...).

Далее он развивает весьма сложную теорию (см. Gil, 2000, Figure 4).

Для целей данной статьи наиболее важна комбинация тождественности: $\mathrm{X} \leftrightarrow(\mathrm{X}, \mathrm{X}, \mathrm{X}$...). Если $\mathrm{X}$ - категория предложений, то последовательность любой длины элементов этой категории (предложений) снова относится к этой же категории.

Почти все слова риау индонезийского (кроме небольшого замкнутого класса служебных слов) имеют одинаковое синтаксическое поведение и относятся к начальной категории $\mathrm{S}^{0}$. В широком спектре контекстов почти все слова могут выполнять функции полных не эллиптических предложений. Д. Гил пишет: «...Moreover, any $\mathrm{S}^{0}$ word can combine with any other $\mathrm{S}^{0}$ words, in accordance with the rule of Identity Combination, to yield a multi-word $\mathrm{S}^{0}$ expression, and so on recursively ${ }^{3}$ (Gil, 2000, p. 200).

Таким образом, операция «комбинация тождественности», последовательно добавляющая слова (предложения) в стиле операции 'merge' в минималистской теории, трактуется Д. Гилом как рекурсивная.

Итак, риау индонезийский в этом аспекте ведет себя аналогично пирахан: сложноподчиненные предложения отсутствуют, однако сколь угодно длинные цепочки высказываний (сложносочиненные предложения?) присутствуют, причем они генерируются рекурсивным образом.

\section{Есть ли рекурсия в языке обезьян?}

Хорошо известные попытки научить обезьян человеческому языку (Зорина, Смирнова, 2006; Зорина, 2008) привели к весьма интересным результатам. Понимание простых предложений у обезьян оказалось на уровне двухлетнего ребенка. В известном эксперименте (Зорина, Смирнова, 2006, с. 233-236) по сравнению понимания заданий на естественном языке обезьяной и ребенком в возрасте двух лет обезьяна правильно выполнила $81 \%$ заданий, а ребенок - только 64\%. Мно-

\footnotetext{
3 Более того, любое слово $\mathrm{S}^{0}$ может комбинироваться с любым другим словом $\mathrm{S}^{0}$ в соответствии с правилом комбинации тождественности, чтобы породить выражение $\mathrm{S}^{0}$, состоящее из нескольких слов, и далее рекурсивным образом.
}

гие аспекты человеческого языка оказались доступны и обезьянам, включая такие нетривиальные, как перемещаемость (Hokket, 1960) и продуктивность (Зорина, Смирнова, 2006). Под продуктивностью понимается способность порождать из известных слов новые высказывания, которые никогда ранее обезьяна не слышала.

Что же касается производства длинных последовательностей высказываний, то как раз тут успехи обезьян весьма ограниченны. В подавляющем большинстве случаев собственные высказывания обезьян ограничиваются 2-3 «словами». В таких коротких предложениях просто нет места для рекурсии. Однако известен следующий поразительный пример (Зорина, 2008, c. 157). Лаборантка (Сьюзен) «нечаянно» наступила на любимую куклу обезьяны, и та реагировала следующим образом: «Сьюзен встань; встань Сьюзен; я прошу встань; дай мне бэби; убери ботинок», и еще 5-6 высказываний подобного рода. Характерно здесь не простое повторение просьбы одним и тем же способом, а развитие темы, представление ее с разных сторон.

Здесь мы наблюдаем совершенно типичную конструкцию, получаемую рекурсивной процедурой 'merge'. Таким образом, в языке обезьян присутствует рекурсивная составляющая в некоторой зачаточной форме. Это подтверждается и примерами, когда обезьяны правильно понимали сложноподчиненные предложения в обращенной к ним речи. Теоретически, того запаса слов, который обезьянам удалось усвоить, вполне достаточно для порождения сколь угодно длинных текстов с неповторяющимися фразами. Например, обезьяна могла бы комментировать свои действия примерно так: «Вижу на столе банан; хочу есть; подхожу к столу; беру банан и ем его; теперь хочу поиграть с куклой; где она? ...». Однако таких длинных комментариев не наблюдается. Вероятно, можно согласиться с точкой зрения, высказанной С. Пинкером и Р. Джанкендорффом: «Действительно, единственная причина, по которой язык должен быть рекурсивным, - та, что он предназначен для выражения рекурсивных мыслей» (Пинкер, Джанкендорфф, 2008, с. 280).

\section{Заключение}

Пирахан, бесспорно, очень интересный язык, однако он отнюдь не является единственным языком без сложноподчиненных конструкций. Выраженное в ряде публикаций мнение, что только вложенные сложноподчиненные конструкции могут выражать рекурсию, представляется ошибочным, основанным на ограниченной трактовке рекурсии в ранних версиях теории Хомского. В действительности поздние варианты теории Хомского допускают выражение рекурсии иными средствами, а не только вложенными сложноподчиненными конструкциями.

Задолго до выхода в свет книги Д. Эверетта язык также без вложенных сложноподчиненных конструкций - риау индонезийский - описал Д. Гил. Вероятно, это был первый открытый язык с такими свойствами, не являющийся пиджином. Однако его описание не привело ни к краху теорий Хомского, ни к появлению 
сколько-нибудь широко признанных новых универсальных синтаксических теорий. Фактически ни один из господствующих подходов: когнитивизм, функционализм и т.д. - никак не прореагировали на это событие. Представляется, что и пирахан также не приведет к пересмотру базовых лингвистических теорий.

\section{Литература}

Бурлак С. А. Язык пираха и разговорная речь // Российский журнал когнитивной науки. 2018. Т. 5. №1.

Зорина 3.А. Возможность диалога между человеком и человекообразной обезьяной: обзор экспериментальных исследований // Разумное поведение и язык. М.: Языки славянской культуры, 2008. С. $135-172$.

Зорина 3. А., Смирнова А.А. О чем рассказали «говорящие» обезьяны. М: Языки славянских культур, 2006.

Коротаев Н.А. Просодическая организация сложноподчинённых конструкций // Рассказы о сновидениях: Корпусное исследование устного русского дискурса. М.: Языки славянских культур, 2009. С. $488-522$.

Лопатко Е. Рекурсивные лингвистические структуры // Теоретические и прикладные проблемы русской филологии: Научно-метод. сборник. Славянск: СГПУ, 2014. С. 86 - 95.

Маршак С. Дом, который построил Джек. М.: Художественная литература, 1968.

Перехвальская Е.В. Русско-китайский пиджин и русский «интерязык» // Acta Linguistica Petropolitana. Труды ИЛИ. СПб.: Наука, 2013. С. 331-345.

Пиджин // Энциклопедия Кругосвет. URL: http://www. krugosvet.ru/enc/gumanitarnye nauki/lingvistika/PIDZHIN.html.

Пинкер С., Джанкендорфф Р. Компоненты языка: что специфично для языка и что специфично для человека? // Разумное поведение и язык. М.: Языки славянской культуры, 2008. С. $261-291$.

Сулейманов Д.Ш. Когнитивные возможности татарского языка для развития средств обработки знаний // Труды международного симпозиума «Типология аргументной структуры и синтаксических отношений». Казань: КГУ, 2008. C. $99-109$.
Хомский Н. О природе и языке. М.: КомКнига, 2005.

Эверетт Д. Л. Не спи - кругом змеи! Быт и язык индейцев амазонских джунглей. М.: ЯСК, 2016.

Chomsky N. On nature and language / A. Beletti, L. Rizzi (Eds.). Cambridge: Cambridge University Press, 2002.

Chomsky N. The minimalist program. Cambridge: MIT Press, 1995.

Everett $D$. Don't sleep, there are snakes: Life and language in the Amazonian jungle. New York: Pantheon Books, 2008.

Gil D. Syntactic categories, cross-linguistic variation and universal grammar // Approaches to the typology of word classes / P.M. Vogel, B. Comrie (Eds.). Berlin: Mouton de Gruyter, 2000. P. $173-216$.

Gil D. Riau indonesian as a pivotless language // Typology and linguistic theory, from description to explanation. For the 60th Birthday of Aleksandr E. Kibrik Moscow: LRC Publishing, 1999. P. $187-211$.

Gordon P. Numerical cognition without words: Evidence from Amazonia // Science. 2004. Vol.306. No.5695. P.496-499. doi:10.1126/science.1094492

Greenberg J.H. Some universals of grammar with particular reference to the order of meaningful elements // Universals of human language / J.H. Greenberg (Ed.). Cambridge, Mass: MIT Press, 1963. P.73-113. Hokket C. W. Origin of speech // Scientific American. 1960. Vol.203. P.88-96.

KibrikA.E. Beyond subject and object: Toward a comprehensive relational typology // Linguistic Typology. 1997. Vol.1. P.279-346.

Nevins A., Pesetsky D., Rodrigues C. Pirahã exceptionality: A reassessment // Language. 2009. Vol.85. No.2. P.355- 404.

Theil $R$. What is the world's weirdest language? // Science Nordic 2016. URL: http://sciencenordic.com/whatworld\%E2\%80\%99s-weirdest-language (March 23, 2018)

Zorina Z.A. The possibility of dialog between human and great apes: the review of experimental studies // Language and reasoning. Animal communication and human language. Language origins / A.D. Koshelev, T.V. Chernigovskaya (Eds.). Moscow: LRC Publishing, 2008. P.135-172. 


\title{
Riau Indonesian, Pirahã: What's Next?
}

\section{Valery Solovyev}

Kazan Federal University, Kazan, Russia

\begin{abstract}
This paper is devoted to the disputed presence of recursion in the Pirahã language. The viewpoint that there is no recursion in this language, and that its existence is therefore inconsistent with the basic postulates of Chomsky's theories, seems erroneous and based on a narrow understanding of recursion as complex syntactic constructions. The present paper considers several types of linguistic constructions that may be understood to be recursive in a broader sense originating from the mathematical notion of recursion. It is shown that recursion as a property of thought may be implemented in such verbal structures, and not only in traditional recursive syntactic constructions. Such recursion is represented in the Pirahã language in its compound sentences. Examples of other languages with similar properties are given: the previously described Riau Indonesian and pidgin languages. The language of talking apes also provides promising material for the topic of alternative implementation of recursion, since apes are very limited in the production of long utterances.
\end{abstract}

Correspondence: Valery Solovyev, maki.solovyev@mail.ru, Solovyev Valery, p/b 93, 420101, Kazan, Russia

Keywords: Pirahã, recursion, Chomsky’s theory, compound sentences, talking apes

Copyright (C) 2018. Valery D. Solovyev. This is an open-access article distributed under the terms of the Creative Commons Attribution License (CC BY), which permits unrestricted use, distribution, and reproduction in any medium, provided that the original author is credited and that the original publication in this journal is cited, in accordance with accepted academic practice.

Acknowledgements. This work was funded by the subsidy allocated to Kazan Federal University for the state assignment in the sphere of scientific activities, grant agreement no.34.5517.2017/6.7. The author is grateful to anonymous reviewers whose helpful advice substantially contributed to the improvement of this text.

Received May 29, 2017, accepted March 23, 2018.

\section{References}

Burlak, S.A. (2018). Pirahã and spoken language. The Russian Journal of Cognitive Science, 5(1) pp.22-26 (In Russian).

Chomsky, N. (2002). On nature and language. Cambridge: Cambridge University Press.

Chomsky, N. (1995). The minimalist program. Cambridge: MIT Press.

Everett, D. (2008). Don't sleep, there are snakes: Life and language in the Amazonian jungle. New York: Pantheon Books.

Gil, D. (2000). Syntactic categories, cross-linguistic variation and universal grammar. In P.M. Vogel, \& B. Comrie (Eds.), Approaches to the typology of word classes (pp.173-216). Berlin: Mouton de Gruyter.

Gil, D. (1999). Riau indonesian as a pivotless language. In Typology and linguistic theory, from description to explanation. For the 60th Birthday of Aleksandr E. Kibrik (pp.187-211). Moscow: LRC Publishing.

Gordon, P. (2004). Numerical cognition without words: Evidence from Amazonia. Science, 306(5695), 496-499. doi:10.1126/ science.1094492

Greenberg, J.H. (1963). Some universals of grammar with particular reference to the order of meaningful elements. In J.H. Greenberg (Ed.), Universals of human language (pp.73-113). Cambridge, Mass: MIT Press.
Hokket, C.W. (1960). Origin of speech. Scientific American, 203, $88-96$.

Kibrik, A.E. (1997). Beyond subject and object: Toward a comprehensive relational typology. Linguistic Typology, 1, 279-346.

Korotaev, N.A. (2009). Prosodicheskaia organizatciia slozhnopodchinennykh konstruktcii [Prosodic organization of nested constrauctions]. In A.A. Kibrik, \& V.I. Podlesskaia (Eds.), Rasskazy o snovideniiakh: Korpusnoe issledovanie ustnogo russkogo diskursa [Stories about dreams. Corpus research of Russian spoken discourse] (pp.488-522). Moscow: LRC Publishing. (In Russian).

Lopatko, E. (2004). Rekursivnye lingvisticheskie struktury. In V.A. Glushchenko (Ed.), Teoreticheskie $i$ prikladnye problemy russkoi filologii: Nauchno-metod. sbornik, Vol. XII. (pp. 86-95). Slavyansk: SGPU. (In Russian).

Marshak, S. (1968). Dom, kotoryi postroil Dzhek [The house that Jack built]. Moscow: Khudozhestvennaya literatura. (In Russian).

Nevins, A., Pesetsky, D., \& Rodrigues, C. (2009). Pirahã exceptionality: A reassessment. Language, 85(2), 355-404.

Perekhvalskaya, E.V. (2013). Russko-kitaiskii pidzhin i russkii "interyazyk" [Russian-Chinese pidgin and Russian "interlanguage"]. In Acta linguistica Petropolitana. Trudy instituta lingvisticheskikh issledovanii, Vol.9. (pp.331-345). SaintPetersburg: Nauka. (In Russian). 
Pidzhin [Pidgin]. (n.d.). Entsiklopediya Krugosvet [Encyclopedia "Around the World"]. (In Russian). Retrieved from http:// www.krugosvet.ru/enc/gumanitarnye nauki/lingvistika/ PIDZHIN.html.

Pinker, S., \& Jackendoff, R. (2009). The components of language: What's specific to language, and what's specific to humans. In M.H. Christiansen, C. Collins, \& S. Edelman (Eds.), Language universals (pp.126-151). New York: Oxford University Press. doi:10.1093/acprof:oso/9780195305432.001.0001

Suleimanov, D.S. (2008). Kognitivnye vozmozhnosti tatarskogo yazyka dlya razvitiya sredstv obrabotki znanii [Cognitive options for development of the knowledge processing means provided by the tatar language]. In Trudy mezhdunarodnogo simpoziuma "Tipologiya argumentnoi struktury $i$ sintaksicheskikh otnoshenii" [Proceedings of the international symposium "Typology of the argument structure and syntactic relations"] (pp.99-109). Kazan: Kazan State University. (In Russian).

Theil, R. What is the world's weirdest language? (2016). Science Nordic. Retrieved http://sciencenordic.com/what-world\%E2 $\% 80 \% 99$ s-weirdest-language

Zorina, Z.A. (2008). The possibility of dialog between human and great apes: the review of experimental studies. In A.D. Koshelev, \& T.V. Chernigovskaya (Eds.), Language and reasoning. Animal communication and human language. Language origins, Vol.1. (pp.135-172). Moscow: LRC Publishing. (In Russian).

Zorina,Z.A., \& Smirnova,A.A. (2006). O chem rasskazali "govoryashchie" obezyany [What "talking apes" told]. Moscow: LRC Publishing. (In Russian). 
племени пираха)

\title{
Алексей Дмитриевич Кошелев
}

Издательский дом «ЯСК», Москва, Россия

\begin{abstract}
Аннотация. Одна из центральных тем статьи - характер влияния культуры социума на его язык. Показывается, что прогресс социума способствует развитию содержательного компонента языка - расширению круга его лексических и грамматических значений. Обсуждается гипотеза Д. Эверетта о влиянии культуры на строй языка. Предлагаются модели деятельностного развития человека и социума, образованные тремя компонентами: Деятельность (главный компонент), Мышление и Язык (вспомогательные компоненты, обеспечивающие успешное осуществление деятельности). В свете этих моделей анализируются некоторые необычные свойства языка племени пираха, описанные Эвереттом: отсутствие цветообозначающих и счетных слов, страдательного залога и др. Показано, что эти свойства обусловлены начальным уровнем прогресса племени и, предположительно, элиминировались бы в случае его перехода на последующие уровни прогресса.
\end{abstract}

Контактная информация: Алексей Дмитриевич Кошелев, koshelev47@gmail.com; 107031, Москва, Большая Лубянка, д. 13/16, стр. 1.

Ключевые слова: пираха, деятельность, мышление, развитие языка, культура, цветообозначающие слова, счетные слова, модель человека

( 2018 Алексей Дмитриевич Кошелев. Данная статья доступна по лицензии Creative Commons "Attribution" («Атрибуция») 4.0. всемирная, согласно которой возможно неограниченное распространение и воспроизведение этой статьи на любых носителях при условии указания автора и ссылки на исходную публикацию статьи в данном журнале в соответствии с канонами научного цитирования.

Статья частично основана на материалах более раннего послесловия к книге Д. Эверетта: Комелев А.Д. Пираха как пример языка, «застывшего» на начальной стадии эволюции / Д.Л. Эверетт. Не спи - кругом змеи! Быт и язык индейцев амазонских джунглей. Послесловие. М.: Языки славянских культур, 2016. С.341-378.

Благодарности. Выражаю глубокую благодарность Л.Г. Зубковой и Е.В. Печенковой за плодотворные обсуждения всех разделов статьи и ценные советы. Я также благодарен анонимным рецензентам за полезные замечания.

Статья поступила в редакцию 24 мая 2017 г. Принята в печать 26 марта 2018 г.

\section{1. Введение}

1.1. О языке пираха: влияет ли культура на язык? Согласно исследованиям Д. Эверетта, языку пираха - небольшого одноименного племени охотниковсобирателей, живущих на берегах реки Маиси (притока Амазонки), - присущ целый ряд редких лексических и грамматических свойств: отсутствие числительных, цветообозначающих имен, грамматической категории числа, страдательного залога, рекурсии, бедность лексических показателей времени, родства и др. (Everett,
2005, 2009; Futrell et al., 2016; Эверетт, 2016). Как считает Эверетт, эти свойства, делающие язык пираха одним из самых экзотичных человеческих языков, обусловлены столь же необычной культурой этого племени.

В документальном фильме «Код Амазонки „Грамматика счастья“» (2012 г.) Эверетт говорит: «Я хочу доказать, что культура оказывает влияние не только на словарь языка, но и на его строй. И язык пираха - яркое тому подтверждение». 
Как он сам подчеркивает, эта точка зрения антагонистична позиции генеративистов:

«Как и большинство современных лингвистов, я раньше считал, что культура и язык в целом не зависят друг от друга. Однако, если я прав в том, что культура может сильно влиять на грамматику, то тогда... идея, что грамматика является частью человеческого генома и вариации в грамматиках языков мира в целом незначительны, в корне неверна» (Эверетт, 2016, с. 258).

Поэтому не удивительно, что научные взгляды Эверетта подверглись резкой критике со стороны ученых, в той или иной степени близких к генеративизму, - см. мнение, высказанное в том же фильме С. Пинкером:

«Возможно, самое смелое утверждение Эверетта то, что необычные характеристики языка пираха - порождение их культуры. Есть общее правило, с которым согласятся все лингвисты: что различия языков мира не имеют ничего общего с различиями в культурах народов, говорящих на них. Чтобы не быть голословным, в некоторых языках дополнение ставится после глагола, например Джон ел суши, а в некоторых - перед ним: Джон суши ел. Но соотносится ли это с культурой?.. Ответ - нет.»

См. также критические статьи А. Невинса и коллег (Nevins et al., 2009a, b).

Итак, в современной лингвистике вновь обрело актуальность антагонистическое противостояние: «культура влияет на язык» vs «культура не влияет на язык». Здесь нет возможности даже кратко охарактеризовать историю вопроса. Остановимся лишь на взглядах Э. Сепира и И. А. Бодуэна де Куртенэ, близких к излагаемой ниже точке зрения.

1.2. Сепир и Бодуэн де Куртенэ о влиянии культуры на язык. Коснемся сначала взглядов Э. Сепира. Прежде, конечно, нужно определиться с трактовкой понятия «культура». Согласно Сепиру «культура... может быть кратко определена как цивилизация, взятая в той мере, в какой она воплощает в себе национальный дух» (Сепир, 1993, с. 469); «культуру можно определить как то, ч т о данное общество делает и думает» (там же, c. 193; выделение автора. - A.К.). В этом понимании культуры важно разграничить две составляющие: неизменную - «национальный дух» и изменяющуюся со временем - «цивилизацию», «то, что общество делает». Говоря о языке в контексте рассматриваемой проблемы, Сепир различает в нем содержательную составляющую - словарь, отражающий «культурный фон данного общества» (там же, с. 276), — и грамматическую систему. Касательно влияния культуры этнической группы на ее язык Сепир указывал, что в начальный период ее существования (то есть в «примитивной группе с едва различимыми зачатками языка и культуры») развитие языка (как его содержания, так и грамматической системы) зависело от развития культуры. Оно

«происходило в известной степени параллельно, т. е. явления культурной деятельности получали свое отражение в грамматической системе языка. Иными словами, дело не только в том, что слова служили символами для отдельных элементов культуры... но и в том, что, как мы можем предположить, грамматические категории и процессы сами по себе тоже отражали соответствующие (значимые с точки зрения культуры) типы мысли и деятельности» (Сепир, 1993, с. 282).

В процессе дальнейшего развития такой группы причинно-следственные отношения между культурой - ее быстро изменяющейся цивилизационной составляющей - и языком, с его гораздо медленнее изменяющейся формой, сохраняются, но становятся более расплывчатыми и трудноуловимыми, ср.:

«Хотя формы языка не могут изменяться так же быстро, как соответствующие формы культуры, почти не вызывает сомнения тот факт, что резкое изменение культурной организации общества сопровождается ускорением языкового развития. Если же довести эту мысль до логического завершения, мы вынуждены будем признать, что быстрое усложнение культуры с необходимостью ведет к соответствующим, хотя и не столь быстрым, изменениям языковой формы и содержания. <..> Я не склонен считать случайностью тот факт, что быстрое развитие культуры в Западной Европе на протяжении последних 2000 лет сопровождалось языковыми изменениями, которые представляются необыкновенно быстрыми. И хотя привести строгие доказательства моей точки зрения невозможно, я все же сомневаюсь в том, что многие языки примитивных народов претерпели в соответствующий период времени столь же существенные изменения» (там же, с. 283).

Следует отметить, что с течением времени позиция Сепира несколько изменяется. Приведенная цитата взята из его доклада, сделанного в 1911 году. В его статье, опубликованной в 1933 году, можно прочесть: «Не существует никакой корреляции между культурным типом и языковой структурой» (там же, с. 242).

Бодуэн де Куртенэ, касаясь происходящих в языке изменений, отмечает, что они «постоянны и вечны, потому что причины, их вызывающие, постоянны и вечны» (Бодуэн де Куртенэ, 1963, т. I, с. 249). Среди общих причин, вызывающих языковые изменения, он называет «бессознательную абстракцию, стремление к разделению и дифференцировке» (там же, т. I, c. 102) - причину, которая, как мы покажем далее, является одной из важнейших.

По мысли Бодуэна, наряду с изменениями колебательного характера языку присуще однонаправленное движение, обусловленное «объективным прогрессом человека как одного из звеньев природы» (там же, т. I, c.349). Это движение Бодуэн называет прогрессом языка. Важнейшей «внутренней чертой этого прогресса является все более растущая абстрактность языка» (там же, т. I, с. 236). А она, в свою очередь, ведет «ко все большему одухотворению языка» (там же, т. I, с. 262). 
Наша же позиция, если говорить предельно коротко, сводится к следующему. Культура человеческого сообщества существенно влияет на его язык. Однако это влияние весьма избирательно и касается, главным образом, уровня цивилизации сообщества и содержательной стороны языка. А именно: цивилизационная составляющая культуры, изменяющаяся вместе с прогрессом сообщества, предопределяет развитие содержательной составляющей языка (к ней мы относим совокупность как лексических, так и грамматических значений). Как мы постараемся показать, главным критерием прогресса социума является постоянное расширение осуществляемых в нем видов деятельности. Благодаря этому присущая социуму картина мира становится все более и более дифференцированной и системной. А это влечет постоянное пополнение содержательной составляющей языка новыми лексическими и грамматическими единицами, абстрактными, метафорическими и метонимическими значениями и пр. Далее в статье этот процесс подробно проиллюстрирован на примере племени пираха. Будет показано, что отсутствие или бедность многих лексических и грамматических средств их языка связано с недифференцированностью (синкретичностью) соответствующих фрагментов их картины мира. А эта синкретичность, в свою очередь, обусловлена предельно узким кругом видов деятельности индейцев, знаменующим начальный уровень прогресса племени.

Далее в разделе 2 дается общетеоретическая основа излагаемой точки зрения, а в разделе 3 - иллюстрация общих положений на примере анализа культуры и языка племени пираха.

\section{2. О моделях деятельностного развития человека и этногруппы}

2.1. Единая линия прогресса этнической группы. Уточним используемое в данной статье понятие этнической группы. Этнической группой, или, коротко, этногруппой, мы называем сообщество людей, объединенное общим языком, культурой и кругом обыденных (общепонятных) видов деятельности (мы оставляем без рассмотрения проблему этнического самосознания, которое обычно используется как критерий выделения этногрупп, так как это напрямую не связано с целями данной статьи).

Уровень прогресса этногруппы определяется качественным разнообразием видов деятельности, осуществляемых в этой группе. Начальный уровень прогресса характерен для гомогенной группы, в которой отсутствуют специфические, так сказать профессиональные, виды деятельности (например, гончарное производство). Такие виды деятельности осуществляют отдельные коллективы, используя при этом особый, профессиональный язык. В осуществлении обыденных (непрофессиональных) видов деятельности участвуют все члены этногруппы, используя при этом обыденный (общепонятный) язык. Примером гомогенной этногруппы может служить племя пираха. Этногруппы, в которых культивируются профессиональные виды деятельности, мы называем гетерогенными.
Введенные понятия тесно связаны с некоторыми понятиями теории Л. Моргана о едином пути прогресса человеческих сообществ (Морган, 1935). Эта теория пережила период своего расцвета во второй половине XIX века и сейчас редко упоминается в научных исследованиях. Тем не менее в ней, на наш взгляд, содержатся «зерна истины», и некоторые ее положения кажутся нам весьма плодотворными (не следует забывать, что она базируется на анализе этнографических сведений о множестве племен, обитающих на разных континентах, и что некоторые их этих племен были открыты во времена Моргана и находились еще в своем первозданном виде).

Терминологическое замечание. Многие понятия моргановской теории периодов прогресса этногрупп вошли в научный аппарат современной антропологии, однако терминология Л. Моргана почти не используется. Одна из причин кроется в ее уничижительных коннотациях («дикость», «варварство»), невольно приписываемых многим архаичным племенам. Последующие периодизации были основаны на других критериях, акцент сместился с социальной структуры на более легко реконструируемую по археологическим данным материальную культуру сообществ (палеолит, мезолит, неолит и др.). Однако для наших задач систематика Моргана гораздо полезнее классификации современной социальной антропологии. Поэтому в нашей терминологии мы устраняем нежелательные коннотации, но сохраняем многие моргановские понятия.

В теории Моргана выделены три периода прогресса этногрупп («дикость», «варварство» и «цивилизация»), каждый из которых представляет собой определенное состояние общества и отличается свойственным этому периоду образом жизни (Морган, 1935). Для нас важны первые два периода, характеристики которых мы будем далее использовать:

1) «дикость» - начальный период прогресса, для которого характерны отсутствие частной собственности и равенство членов общества, и

2) «варварство» - последующий период прогрес$\mathrm{ca}$, отмеченный появлением гончарного производства, земледелия, скотоводства, частной собственности и социальной иерархии.

Введенные выше понятия гомогенных и гетерогенных этнических групп соответствуют классификации Моргана: период «дикости» соответствует периоду гомогенности, а начиная с периода «варварства» этногруппа становится гетерогенной. На основе проделанного Морганом анализа можно сделать следующий вывод: переломным моментом, знаменующим качественно новый этап в прогрессе этногруппы, является ее переход из гомогенного периода в гетерогенный. Для гетерогенной этногруппы характерно наличие специальных, профессиональных видов деятельности, которыми занимаются лишь отдельные коллективы в этногруппе. Для гомогенного социума характерно отсутствие таких видов деятельности. Все виды деятельности относятся к сфере обыденной жизни, то есть 
доступны для осмысленного участия практически любому ее члену.

Среди профессиональных видов деятельности, изменяющих структуру этногруппы, важнейшую роль Морган отводит гончарному производству. На первый взгляд, этот тезис выглядит странно. Почему именно гончарное производство оказывается столь важным, радикально меняющим статус группы? Ведь известно, и Морган поддерживает это положение, что по своему влиянию и последствиям величайшим из событий в истории человеческого опыта было начало производства железа.

Поясним нашу мысль. Во-первых, возникновение гончарного производства было само по себе важным завоеванием человека. Оно дало жаропрочную посуду для варки пищи, производившейся до того примитивным способом, в обмазанных глиной корзинах и в ямах, обложенных шкурами. При этом варка осуществлялась при помощи раскаленных камней. Начиналось гончарное производство с обмазывания деревянной посуды толстым слоем особого рода глины («толщиной в добрый палец») для защиты ее от действия огня. И только позднее обнаружилось, что глина и одна отвечает этой цели.

Во-вторых, и это самое важное, согласно Моргану (1935), гончарное производство во множестве случаев становится первым профессиональным видом деятельности, которым занимается не все племя, а лишь его небольшая группа. Именно с этого момента прежде гомогенное общество начинает социально и профессионально дифференцироваться и превращается в гетерогенное.

2.2. Племя пираха и гончарное производство. Проведенный Д. Эвереттом анализ повседневной жизни индейцев показывает, что племя пираха находится в периоде гомогенности, в котором еще сохраняется равенство всех его членов и практически полное отсутствие частной собственности. Пираха уже владеют луком и стрелой, но еще не имеют ни гончарного производства, ни каких-либо других видов профессиональной деятельности - такой достаточно сложной деятельности, которая требует специальных навыков, знаний и языка общения и потому доступна далеко не всем членам племени. Охота, рыбная ловля, собирательство, приготовление пищи, плетение корзин, ручное прядение (практически в каждой семье есть «традиционная ручная прялка» (Эверетт, 2016, с. 95)), отдых у костра и пр. - все это виды обыденной деятельности, понятные в деталях всем индейцам, причем не только взрослым, но и подрастающим детям, которые приучаются к ним с раннего возраста. Ведь члены каждой семьи и охотятся, и ловят рыбу, и собирают в лесу плоды и коренья, и плетут корзины, и участвуют в постройке новой хижины и т. д.

Гомогенному состоянию племени пираха соответствует язык, лишенный, как уже отмечалось выше, целого ряда типичных лексических и грамматических единиц: счетных слов; цветообозначающих имен (вместо них используются аналоговые выражения типа «подобный крови» (для красного цвета), «подобный траве после дождя» (для зеленого цвета)); лексических показателей времени типа вчера, сегодня, завтра, утро, вечер, неделя, месяи; страдательного залога и др. Ниже, в разделе 3, мы подробно покажем, что отсутствие этих языковых средств обусловлено отсутствием среди видов деятельности индейцев пираха соответствующих практик. В их обыденной деятельности не используется счет; отдельные цвета не несут идентифицирующей функции, подобной цвету светофора; их жизнь не делится на привычные нам временные циклы, именуемые словами утро, вечер, вчера, завтра и подоб. (они спят урывками и днем, и ночью); в их быту не встречается действий, которые принято именовать страдательным залогом, и т.д.

Чтобы проиллюстрировать возможный путь появления в языке индейцев пираха отсутствующих лексических и грамматических единиц, представим мысленно, что в их племени появился первый вид профессиональной деятельности. Предположим, что большая семья индейцев пираха, следуя своим наиболее креативным членам, начала осваивать гончарное производство. Прежде всего у этой семьи и ее окружения появляется целый спектр новых взаимосвязанных действий: добывание подходящего вида глины, сбор ракушек, изготовление смеси глины и толченых ракушек, обмазывание этой смесью деревянной и плетеной посуды, высушивание ее в определенных условиях (с поливом водой и пр.), подсчет изготовленной посуды и ее хранение, прием заказов, обмен готовых изделий и т. д. Практически вся эта деятельность должна проходить в светлое время суток. Поэтому все семейство начинает жить в совершенно ином временно́м режиме, чем остальное племя: днем все работают, а ночью спят. Со временем ассортимент производимой продукции расширяется, появляются изделия разных форм и размеров; у приезжих торговцев приобретается краска, и производимая посуда раскрашивается в разные цвета; и т.д.

Очевидно, что вся эта деятельность становится важным внешним стимулом для концептуализации категорий счета, цвета, размера и времени. У членов семейства и связанных с их деятельностью членов племени появляется потребность в новых классах лексики - в названиях конкретных размеров и форм изделий (большоц̆, средниц̆, маленькиц̆; круглый, плоский, глубокий...), их количества (два, три...), раскраски (зеленыц , красныци...), времени изготовления (вчера, завтра) и пр.

Некоторые виды работ, будучи долговременными, уже не отвечают свойственному индейцам принципу непосредственности восприятия («здесь и сейчас», см. п. 3.7) - изменения протекают медленно и недоступны прямому наблюдению. Кроме того, часто неизвестен или неважен и производитель такой работы. Важно лишь знать ее текущее состояние - промежуточный или окончательный результат. А значит, возникает потребность в использовании пассива: Ваш заказ выполняется, Миски будут готовы завтра и подоб. Так возникают условия, при которых доминирующая роль принципа непосредственности восприятия в жизни индейцев начинает утрачиваться.

Как мы видим, при подобном развитии событий в племени появляются многие отсутствующие ранее практики, а вместе с ними возникают и языковые средства, необходимые для их освоения и описания. 
2.3. Деятельностный рубикон. Уже этот короткий анализ показывает, что гончарное производство и его продукция могут оказывать непосредственное и многоаспектное влияние на жизнь и язык гончаров. Но сходное влияние они могут оказывать и на остальных членов племени, которые выбирают цвет и форму приобретаемых гончарных изделий, учатся пользоваться ими. Их представления о различных периодах суточного времени становятся более дифференцированными и т. д. Под влиянием языка гончаров расширяется и язык племени, пополняясь наиболее часто употребляемыми терминами, выражениями вежливости (практически отсутствующими в языке пираха, впрочем, см. статью А. Кибрика в настоящем выпуске журнала (Кибрик, 2018)) и пр. (подробнее этот процесс рассмотрен в п. 2.6). Таким образом, деятельностный прогресс этнической группы способствует непосредственному развитию и ее языка, и ее представлений об окружающем мире.

Мы видим, что появление в этногруппе профессиональных видов деятельности является, образно говоря, рубиконом, при переходе через который качественно изменяется ее ментальный мир. Ранее прогресс этногруппы сводился лишь к расширению видов обыденной деятельности, знаний о ней и описывающего ее обыденного языка. Поэтому все члены этнической группы одинаково смотрели на окружающий мир, его возможности и опасности. Теперь же - при появлении в этногруппе гончарного производства и других профессиональных видов деятельности, характерных для периода бесписьменной гетерогенности, - в ней появляются отдельные коллективы, у которых к общеэтническому представлению мира добавляется новое, так сказать аналитическое, представление о каких-то его аспектах. Оно отражает их опыт углубленного взаимодействия с этими аспектами, благодаря чему в их картине мира появляются новые элементы, отсутствующие у остальных членов сообщества. А это важнейшее социальное новообразование.

2.4. Минимальная модель деятельностного развития человека. В свете вышесказанного, мы будем рассматривать язык и мышление человека (прежде всего его ментальные репрезентации воспринимаемой действительности) не отдельно друг от друга, а в единстве с третьей составляющей - человеческой деятельностью. Как будет показано ниже, человеческая деятель-

(1)

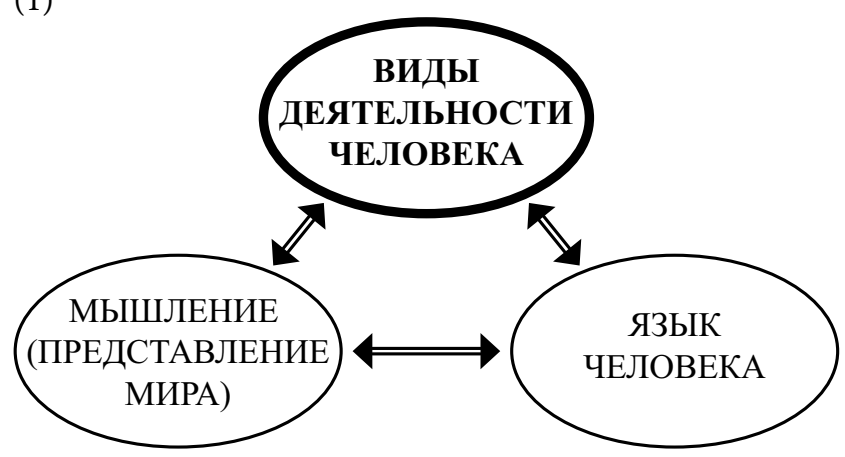

a ность, точнее, совокупность ее конкретных видов, осуществляемых человеком, служит одним из важнейших стимулов для развития человеческого мышления (представления знаний о мире) и языка. Иначе говоря, в центре нашего внимания будет система «мышление (представление мира) - виды деятельности - язык», в которой подсистема «виды деятельности» является главной, а подсистемы «мышление (представление мира)» и «язык» - дополнительными, способствующими успешной реализации конкретной человеческой деятельности (о взаимодействии этих подсистем у ребенка в процессе его онтогенеза см. нашу работу «Очерки эволюционно-синтетической теории языка» (Кошелев, 2017)). Поскольку ни одна из этих подсистем не может развиваться или эволюционировать, не взаимодействуя с двумя другими, изучать их следует только в рамках единой системы. Эту тернарную систему мы будем называть минимальной моделью деятельностного развития человека (далее - просто моделью), см. рис. 1а. Она позволяет изучать человека как единую деятельностную систему, находящуюся в процессе (на определенном этапе) своего развития. Минимальность предложенной модели состоит в том, что, лишаясь любой из своих подсистем, она перестает быть моделью человека в указанном выше смысле.

Совершенно аналогичную структуру имеет модель этногруппы (1b), складывающаяся из моделей ее членов. В ней виды деятельности представляют собой объединение видов деятельности отдельных членов группы, а представление мира и язык представляют собой усреднения - прототипы соответствующих подсистем отдельных членов этногруппы.

Замечание. Нетрудно усмотреть в моделях (1) некоторые общие черты с подходом Н. Я. Марра, который рассматривает звуковой язык совместно с мышлением и материальным производством. Не имея возможности углубляться в анализ подхода Марра, ограничимся несколькими характеризующими его цитатами: «Язык - создание коллектива в производстве. Нет ни одного слова, ни одной формы, ни одного звука, ни одного лингвистического явления, не прошедшего через осознание, созданное и нормировавшееся коллективным, в последствии массовым производством» (Марр, 1936, с.271); «...Не только мысль и слово, т. е. язык и мышление, но оба они вме-

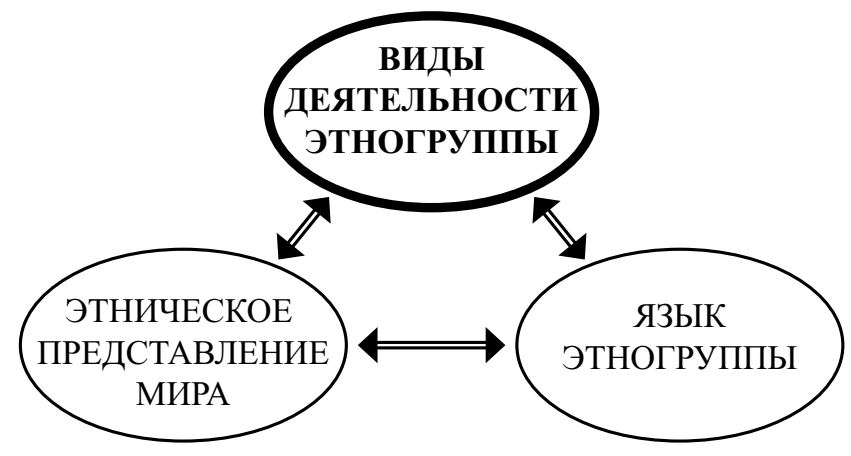

b

Рисунок 1. Минимальные модели деятельностного развития (a) человека и (b) этногруппы. Двусторонние стрелки обозначают взаимосвязи подсистем 
сте с производством составляют единство» (там же, с. 459); «Само собою понятно, что... мышление с его техникой, как и язык, генетически связаны с производством» (Марр, 1933, с. 280).

Различая исходно возникшую и «сотни тысяч лет» существовавшую линейную или ручную (жестовую и мимическую) речь, Марр подчеркивает, что за это длительное время возникли предпосылки для создания звуковой речи, которая «вначале была также лишь частью трудового процесса, производственным языком. Лишь постепенно звуковой язык стал разговорным, представляя в своем древнейшем фонде перевод ручной речи» (там же; см. также Марр, 1936).

\section{5. Модель деятельностного развития челове-} ка: основные понятия. Опираясь на введенные модели, обсудим подробнее сказанное выше о гомогенных и гетерогенных группах. Все члены гомогенной этногруппы занимаются обыденной деятельностью - той устоявшейся, общепринятой совокупностью действий, которая постоянно ими осуществляется для непосредственного поддержания своей жизни. Эта обыденная деятельность обеспечивает насущные потребности членов общества в пище, жилище, безопасности, отдыхе, развлечениях и пр. Она охватывает весь спектр общепринятых бытовых действий и связанных с ними эмоциональных переживаний и физических усилий. Условимся называть совокупность ментальных представлений члена этногруппы, связанных с обыденной деятельностью (ее целями, порядком и деталями исполнения, промежуточными результатами и т. д.), обыденным представлением мира, или обыденными знаниями.

Далее важную роль будет играть различение двух типов знаний о какой-либо деятельности: а) практические (или процедурные) знания, опирающиеся на реальный опыт осуществления этой деятельности и обеспечивающие благодаря этому ее понимание, и б) теоретические знания - ментальные представления о том, как осуществляется данная деятельность, не подкрепленные реальной практикой ее осуществления (они сходны с декларативными знаниями). Примером может служить теоретическое знание, как ехать на велосипеде («сесть на него, оттолкнуться от земли и начать крутить педали, выбирая посредством руля нужное направление»), и практическое знание процесса езды, присущее велосипедисту. Для него характерно не полностью осознаваемое чувственно-моторное, или «телесное», понимание процесса езды, отсутствующее у обладателя теоретических знаний. Из сказанного выше ясно, что круг обыденных знаний относится к практическим знаниям.

С обыденными знаниями и обыденной деятельностью непосредственно связан описывающий их язык. Условимся далее называть этот язык обыденным языком этногруппы ${ }^{1}$. Его адекватно используют и понимают все ее члены.

\footnotetext{
1 Здесь нет возможности сопоставлять введенное нами понятие «обыденный язык» с известным в философии (и весьма неоднозначным) понятием «обыденный язык» (ordinary language) cм., например, работы Г. Райла (Ryle, 1960).
}

Итак, обыденная жизнь члена группы осуществляется благодаря взаимодействию в нем мыслительного (знания), деятельностного и языкового компонентов модели (1a). Понятно, что у всех членов группы эти модели в целом одинаковы.

Оппозицию к обыденной деятельности составляет специфическая, или профессиональная, деятельность. Она осуществляется отдельным коллективом, обособленным от остальных членов этногруппы, с использованием особого, профессионального, языка и специальных понятий, не известных вне этого коллектива. Например, чаепитие относится к обыденной жизни привычного нам общества. Оно широко распространено, и этот процесс хорошо знает (понимает, чувствует) любой член общества. Участие знатоков чая в чайной церемонии - это уже специфическая деятельность, недоступная без специальной подготовки неискушенному любителю чая, требующая знания специальных терминов и особых приемов приготовления чая. Приготовление пищи, счет - это обыденная деятельность, а поварское искусство, бухгалтерские расчеты специфическая, профессиональная деятельность. Она обычно представляет собой развитие какого-то вида обыденной деятельности, превращение ее в профессиональную деятельность, доступную уже далеко не всем членам общества.

Участники профессиональной деятельности обладают пробессиональными знаниями об этой деятельности и практическим опытом в ее осуществлении. Так что типологически знания группы профессионалов аналогичны обыденным знаниям всего племени. В рамках своей профессиональной деятельности коллектив профессионалов создает на основе обыденного языка профессиональный язык. Тем самым, подобно обыденной жизни, профессиональная жизнь коллектива реализуется при взаимодействии тех же трех (но уже профессиональных) составляющих: знания, деятельности и языка. Обладая знаниями и деятельностным опытом, его члены адекватно понимают друг друга, общаясь посредством профессионального языка.

2.6. Пример: медицинская деятельность, и ее влияние на язык и мышление этногруппы. Чтобы пояснить развитие модели (1b) и взаимодействие ее компонентов, обратимся к сравнительно близкой аналогии - к деятельности какого-либо профессионального сообщества и роли профессионального языка в нем. Рассмотрим для примера сообщество профессиональных врачей и ученых-медиков и их медицинский язык. Каждый член этого сообщества владеет обыденным языком этногруппы, к которой он принадлежит, а также медицинским языком. Это особый язык, имеющий структуру обыденного языка, но специальный лексикон, содержащий термины, касающиеся устройства и функционирования человеческого тела, различных болезней, лекарств и пр., и некоторые специальные синтаксические конструкции. Кроме профессионального языка, член медицинского сообщества владеет совокупностью медицинских знаний, дополняющих обыденные представления человека о мире, и умением осуществлять некоторую медицинскую деятельность.

Важно подчеркнуть, что сообщество врачей не может существовать и развиваться в отсутствие хотя бы 
одного из компонентов аналогичной (1a) модели медика - «медицинское представление человека - медицинская деятельность - медицинский язык». Тем более ни один из компонентов этой системы не может существовать и развиваться самостоятельно, в отрыве от двух других. Например, открытие ученым-медиком нового знания о человеческом организме (развитие медицинских представлений) сразу же получает описание на медицинском языке, возможно, с использованием новых терминов (развитие медицинского языка), и быстро становится достоянием медицинского сообщества. А это, в свою очередь, порождает новые методы лечения (развитие деятельности). Тем самым и медицинское сообщество развивается. И напротив, если по тем или иным причинам какие-то виды медицинской деятельности необоснованно сокращаются (запреты, прекращение финансирования), то выходят из употребления и забываются связанные с ними термины и медицинские представления. В медицинском сообществе наступает регресс.

Из этого примера ясно, что главным компонентом модели медика является медицинская деятельность. При ее осуществлении в долговременной памяти медика, например хирурга, формируются нейронные коды конкретных видов этой деятельности, которые накапливают моторный, чувственный и мыслительный опыт (подробнее об этих кодах см. Кошелев, 2017). В памяти же его ассистента, который помогает ему в процессе операции, но непосредственного участия в ней не принимает, такие нейронные коды не формируются. Таким образом, хирург обладает профессиональным знанием (медицинские представления о человеке, или декларативные знания) и чувственно-моторным, или «телесным», пониманием процесса операции (опыт медицинской деятельности, то есть синтезом декларативных и процедурных знаний), а его ассистент - только профессиональным знанием.

Подчеркнем еще раз: именно успешность медицинской деятельности является целью существования сообщества медиков. В этом плане два других компонента являются вспомогательными. Мышление является вторым по важности компонентом. Оно «прокладывает путь» к новым видам деятельности. Медицинский язык является третьим по значимости компонентом. Он активно участвует в формировании первых двух компонентов, поддерживая коллективное мышление и коллективную деятельность.

Отметим одну из важнейший функций языка, без которой развитие медицинского мышления было бы невозможным. Предположим, ученый медик обнаружил новую болезнь, не имеющую однозначной симптоматики (скажем, СПИД). Он называет ее новым термином и посредством медицинского языка начинает разъяснять его значение (сущность болезни) своим коллегам. Тем самым этот термин становится общепонятным в их среде. Без данного термина введенное им новое понятие - ‘болезнь СПИД’ - нельзя было бы сделать достоянием других медиков, поскольку непосредственное указание на ее симптомы здесь не помогает. Таким образом, только термин «удерживает» это понятие, придает ему общезначимый статус. Заметим, что на начальном этапе развития медицинского сооб- щества, когда все болезни были, условно говоря, «сенсорными», то есть манифестировались в мышлении медиков своими наблюдаемыми симптомами, участие языка не было столь критичным. Оно становится таковым, когда появляются, так сказать, «функциональные» болезни, для идентификации которых одной симптоматики недостаточно.

Обратимся теперь к вопросу о влиянии группы профессионалов на остальных членов этногруппы (как на профессионалов в других областях, так и на «непрофессионалов»). Медики непосредственно взаимодействуют с ними как в рамках обыденной жизни, так и при осуществлении медицинских действий и потому оказывают на них многоаспектное влияние. Это касается всех компонентов модели (1a): языка, представлений о мире и деятельности.

Во-первых, расширяется лексикон обыденного языка. В него диффундируют некоторые термины медицинского языка, обретая при этом псевдопрофессиональные (упрощенные) значения, доступные непосредственному пониманию. Это болезни (грипп, ангина, туберкулез и др.), лекарства (горчичники, капли, таблетки, пилюли, микстуры и пр.), процессы лечения (поставить горчичники/капельницу, принять лекарство, наложить гипс, лечь на обследование и подоб.). Подчеркнем: глаголы, именующие эти процессы, употребляются в новых, «медицинских», значениях, не употреблявшихся ранее в обыденной речи. Например, глагол принять употребляется в медицинском значении 'поместить через рот внутрь организма лекарство для лечения'. Поэтому нормально сказать принял порошок/таблетку/микстуру, но нельзя сказать ${ }^{*}$ пинял стакан водь, * принял обед, * принял таблетку, чтобы протестировать ее. Аналогично, можно сказать: наложил повязку на шею, но нельзя сказать *наложил шарф / галстук на шею; лечение наложением рук, но не $п р и$ ложением / * прикладыванием рук.

Новое значение и статус идиомы получает выражение ложиться на. Можно сказать ложусь на гемодиализ / на химиотерапию / на операцию / на обследование. Однако, плохо сказать * ложусь на татуировку / на солнечные ванны. Мы не скажем ${ }^{\star}$ ложусь на массаж, если речь идет об одноразовом массаже на пляже. Однако это выражение корректно, если говорящий имеет в виду курс лечебного массажа. Точно так же выражение ложусь на гипноз корректно в ситуации лечебного гипноза и некорректно при демонстрации техники гипноза.

Во-вторых, в обыденный язык переходят также некоторые синтаксические конструкции и грамматические значения. К перечисленным выше можно добавить и другие. Например, естественно думать, что конструкции типа тогда и только тогда, если и только если пришли из математики, конструкция I will speak the truth, the whole truth and nothing but the truth (Я буду говорить правду, всю правду и ничего, кроме правды) - из юриспруденции, конструкции типа $n p u$ нимать перед едой по три раза в день в течение двух недель - из медицины. ${ }^{2}$

\footnotetext{
2 Приведенные примеры обнажают механизм (через новые профессиональные языки), посредством которого прогресс социума (расширение его профессиональных видов деятельности)
} 
Новая составляющая языка (назовем ее псевдопрофессиональной) имеет самостоятельный статус. Она типологически отлична как от общепонятного обыденного языка, так и от медицинского языка.

Вместе с языком расширяются и другие компоненты модели (1a): знания и деятельность. Значения профессиональных терминов и выражений, «прижившихся» в обыденном языке, пополняют знания непрофессионалов о медицинских ситуациях. Условимся называть эти знания псевдопрофессиональными. В отличие от практических знаний (как обыденных, так и профессиональных), это - теоретические знания, не имеющие опоры на канонические медицинские действия. Будучи поверхностными коррелятами профессиональных знаний, они индивидуализированы и могут различаться у разных людей. К примеру, одни знают о лечении гриппа или ангины одно, другие - coвсем другое, а третьи - практически ничего не знают.

Наконец, расширение набора понятий приводит к умножению и большей дифференциации связанных с ними видов деятельности: определение болезни по внешним симптомам, идентификация лекарств по цвету, форме, типу вещества (порошок, таблетка, капли, микстура), способы их приема (включающие время, регулярность и длительность приема), анализ воздействия и т.д.

Таким образом, все компоненты модели (1a) члена гетерогенной этнической группы дополняются псевдопрофессиональными составляющими:

(2) Деятельность = обыденная + псевдопрофессиональная деятельность;

(3) Представление мира = обыденные + псевдопрофессиональные знания;

(4) Язык = обыденный + псевдопрофессиональный язык.

У профессионала, например медика, в правые части (2)-(4) добавляется еще профессиональная составляющая.

Дальнейший прогресс гетерогенной этногруппы - рост различных видов профессиональной деятельности - приводит ко все большей индивидуализации псевдопрофессиональных компонентов модели. Ввиду этого, вне обыденной деятельности и обыденного языка люди все хуже и хуже понимают друг друга, поскольку их псевдопрофессиональные знания являются теоретическими и индивидуализированными (подробнее об этом см. Кошелев, 2017).

Итак, главным критерием прогресса этногруппы является расширение видов ее деятельности. Это происходит при поддержке двух других развивающихся компонентов: мышления и языка.

Замечание. Сообщество профессионалов, например медиков, взятое само по себе и в начальный период своего существования, являет пример гомогенного профессионального социума, не имеющего внутри себя других специфических видов

продуцирует прогресс языка, то есть развитие его содержательной составляющей - лексических и грамматических средств. Кроме того, они иллюстрируют мысль И. А. Бодуэна де Куртенэ о том, что прогресс языка проявляется в росте его абстрактности, см. п. 1.2. деятельности. В этом плане данный социум пердставляет собой аналог гомогенного племени типа пираха и развивается сходным образом - путем расширения понятных всем медикам видов медицинской деятельности, медицинских понятий и языка. Затем, достигнув некоторого предела гомогенного развития, при котором еще «все все понимают», гомогенный социум начинает делиться на отдельные профессиональные группы, каждая из которых принимается углубленно изучать ту или иную частную проблему (онкологические заболевания, болезнь Альцгеймера и др.). Такая группа вырабатывает свои методы лечения, представления о болезни и характере ее протекания и свой язык. Другие медики теперь лишь поверхностно и фрагментарно, то есть «псевдопрофессионально» понимают этих своих коллег. Тем самым гомогенный социум медиков превращается в гетерогенный, повторяя путь развития исходно гомогенной этнической группы.

По мере развития гетерогенного социума в нем множатся профессиональные (в широком смысле) группы, которые постепенно все белее и более отделяются друг от друга (интеллектуально, социально, культурно). Представители разных групп по многим проблемам перестают понимать друг друга. Единственное звено, связывающее эти группы в единый социум и сохраняющее поле взаимного понимания, - это обыденный компонент их деятельности, языка и представлений о мире. Как только этот компонент утрачивается или становится несущественным, гетерогенный социум утрачивает целостность и распадается.

\section{3. Общая теория развития и проблемы концептуализации языковых значений}

Приведем анализ ряда конкретных примеров, выявляющих существование тесной связи между уровнем развития (разнообразием видов деятельности) этнической группы и ее языком.

3.1. Два принципа развития. В дальнейшем анализе важную роль будет играть общая теория развития, восходящая к фундаментальному труду Г. Спенсера «Основания биологии» (Спенсер, 1899). Она базируется на двух принципах, сформулированных Спенсером (см. также Сеченов, 1952; Соловьев, 1988; Werner, 2004; Чуприкова, 2007; Кошелев, 2011).

Согласно первому принципу развитие некоторой целостности (социума, живого организма или его целостного компонента) состоит в преобразовании этой целостности в систему ее взаимосвязанных компонентов. Такое преобразование осуществляется в два этапа: сначала целостность дифференцируется на несколько самостоятельных компонентов, а затем эти компоненты интегрируются в систему, аутентичную по своей функции исходной целостности.

Согласно второму принципу такое развитие обусловлено взаимодействием двух факторов: внутренне- 
го (генетического) и внешнего, или средового (влияния извне). Говоря словами И. М. Сеченова, который в своей работе «Элементы мысли» (Сеченов, 1952) развил и детально проиллюстрировал этот принцип Спенсера, «всегда и везде жизнь слагается из кооперации двух факторов - определенной, но изменяющейся (нервной. А. К.) организации и воздействия извне» (там же, с. 288; курсив автора. - A. К.).

Проиллюстрируем действие указанных принципов на примере развития синкретичного представления предмета ${ }^{3}$ в иерархическую структуру его признаков и их значений. Этот процесс проходит через два последовательных элементарных цикла развития (обозначаются значком $\searrow$ ). Первый цикл делит синкретичное представление предмета на отдельные признаки (общие свойства): Цвет, Форма, Вес и др. Каждый признак представляет собой синкретичный спектр недифференцированных значений: признак Цвет не разделен на палитру прототипичных цветов и т.д.

Второй цикл делит каждый признак на множество значений (конкретных свойств, или адъективных концептов). Признак Цвет дифференцируется на значения ЗЕЛЕНЫЙ, КРАСНЫЙ..., Форма - на КРУГЛЫЙ, КУБИЧЕСКИЙ, Вес - на ЛЕГКИЙ, ТЯЖЕЛЫЙ.., и т. д. (в отличие от признаков, их значения мы обозначаем именами с прописными буквами). В результате, ментальное представление предмета получает вид трехуровневой иерархической структуры:

\section{(5)}

\begin{tabular}{|c|c|c|c|}
\hline $\begin{array}{l}\text { a. Синкретичный } \\
\text { (целостный) } \\
\text { концепт }\end{array}$ & \multicolumn{3}{|c|}{ ПРЕДМЕТ } \\
\hline & \multicolumn{3}{|c|}{$\diamond$} \\
\hline \multirow[t]{2}{*}{ b. Признаки: } & (Цвет, & Форма & Размер, ...) \\
\hline & $\diamond$ & 0 & $\diamond$ \\
\hline с. Их значения: & $\begin{array}{l}\text { (КРАСНЫЙ, } \\
\text { ЗЕЛЕНЫЙ...) }\end{array}$ & (КРУГЛЫЫЙ...) & $\begin{array}{l}\text { (МАЛЕНЬКИЙ, } \\
\text { БОЛЬШОЙ...) }\end{array}$ \\
\hline
\end{tabular}

В ней на первом уровне (5a) дано синкретичное представление предмета, на втором (5b) - его представление в виде совокупности признаков: Предмет = (Цвет, Форма, Размер,...), а на третьем (5c) - каждый признак представлен совокупностью своих конкретных значений: Цвет = (КРАСНЫЙ, ЗЕЛЕНЫЙ...) и т. д.

Таким образом, синкретичное представление предмета трансформируется в иерархическую систему его признаков и их значений.

По-видимому, дифференциация предметного представления на признаки формируется у ребенка до полуторалетнего возраста, поскольку примерно с полутора лет он уже различает формы предметов, то есть разные значения признака Форма (Landau et al. 1988; Markson et al. 2008), а также значения некоторых дру-

\footnotetext{
3 Термином синкретичность мы обозначаем недифференцированность ментальной репрезентации предмета, ее неразделенность на отдельные компоненты (свойства или части). Ср. в связи с этим приводимое Т. Бауэром описание «примитивного единства сенсорных модальностей», позволяющее воспринимать предмет как «нерасчлененное целое» без «дифференциации зрительных качеств предмета от их тактильных качеств» (Бауэр, 1985, с. 140-144).
}

гих признаков: конкретный размер, вес, фактуру и др. (Бауэр, 1985).

Свидетельством появления в ментальных представлениях ребенка конкретных форм предметов служит тенденция, получившая название «предпочтение формы» (shape bias) (Landau et al., 1988). Она может быть обнаружена у детей с 18 месяцев; ср. ее описание в статье Л. Марксона с соавторами: «Когда дети усваивают имя нового объекта, они имеют тенденцию распространять это имя на другие объекты такой же формы - этот феномен получил название предпочтение формы (shape bias)» (Markson at al., 2008, p. 204).

Разумно предположить, что в этой совокупности Форма становится главным признаком, представляющим объемный предмет, а остальные признаки - дополнительными к ней, поскольку они локализуются в ней и дополняют ее до полного предмета. Тем самым объект представляется в виде иерархической системы своих конкретных свойств (значений признаков), cp. мысль Г. Мура (G. E. Moore) о том, что, в отличие от предикативных прилагательных типа good, прилагательные типа yellow обозначают естественные свойства (natural properties), из которых, как из частей, строятся объекты (см. Вендлер, 1981).

3.2. Концептуализация в сознании ребенка цветовых и других свойств. Наша ближайшая цель - объяснить отсутствие в языке пираха цветообозначающих слов. Для этого сначала необходимо понять закономерности усвоения детьми прилагательных. Здесь наблюдается один весьма примечательный парадокс. В отличие от существительных и глаголов, которые ребенок почти сразу научается использовать семантически правильно (согласно некоторым данным, категории и имена предметов ребенок начинает усваивать с 12 месяцев, а категории и имена действий - на 2-3 месяца позже (Xu, Carey, 1996; Xu, 2007; Waxman, 2008)), семантически правильное употребление прилагательных приходит к ребенку не сразу.

Хотя прилагательные появляются в активном лексиконе ребенка уже с полутора лет, первое время он употребляет их без какой-либо опоры на их значение, лишь имитируя речь окружающих (Blackwell, 2005; Воейкова, 2011). Причем первичное представление о семантических признаках, или разрядах (Цвет, Размер), «обнаруживается раньше, чем различение однородных свойств внутри каждого разряда» (Цейтлин, 1996; цит. по Воейкова, 2011, с. 114-115). Так, ребенок быстро перестает путать разнородные прилагательные, например кисльй и большой, но долго продолжает путать однородные прилагательные, называя большой предмет маленьким и подоб., ср.: «Филипп может употребить название одного цвета вместо другого... он может сказать также плохой вместо хороший или большой вместо маленький. Иными словами, ребенок редко говорит плохой вместо зеленый, но может перепутать плохой и хороший или зеленый и красный» (Воейкова, 2011, c. 218), см. также (Andrick, Tager-Flusberg, 1986; Ebeling, Gelman, 1990; Gasser, Smith, 1998; Цейтлин, 1996).

\footnotetext{
4 "When children learn the name of a novel object, they tend to extend that name to other objects similar in shape - a phenomenon referred to as the shape bias." (Markson at al., 2008, p. 204).
} 
Хорошо известно, что ребенок начинает различать цвета предметов (своих игрушек) не позднее полутора лет (см., например, экспериментальные исследования Г. Л. Розенгарт-Пупко, 1948; 1963). Тем не менее детям требуется еще по меньшей мере год, чтобы научиться семантически правильно употреблять цветообозначающие прилагательные (см. Andrick, Tager-Flusberg, 1986; Цейтлин, 1996, с.5-7). С особым вниманием данный феномен рассматривается в работе М.Д. Воейковой:

«Еще Ч. Дарвин в наблюдениях за языковым развитием своих детей отмечал, что они употребляли первые цветовые прилагательные настолько неадекватно, что в течение некоторого времени он считал их дальтониками (см. об этом [Bornstein 1985: 387-388]) <...> Необходимость в подробном изучении ранних прилагательных продиктована тем, что они составляют целую группу слов, употребляемых детьми не просто ошибочно, но и необъяснимо, без всякой связи с реальными свойствами предметов... <..> Для детей характерна следующая черта: рано понимая, к каким семантическим классам относятся прилагательные, они не различают значения прилагательных внутри этих классов... ребенок редко говорит плохой вместо зеленый, но может перепутать плохой и хороший или зеленыцй и красный. <...> Указанные явления характерны как минимум для ряда индоевропейских языков, можно предположить, что они наблюдаются в большинстве языков, где имеется развитая система имен прилагательных [Dixon 1982; 2004]» (Воейкова, 2011, с. 217-218).

Налицо парадокс: с одной стороны, дети в полтора года различают конкретные цвета предметов, с другой стороны, они в течение последующего года оказываются не способными правильно называть цвета соответствующими прилагательными. И это при том, что правильные употребления цветообозначающих прилагательных ребенок слышит постоянно.

Объяснение данного парадокса связано, на наш взгляд, с рассмотренным выше двухэтапным процессом формирования системного представления предмета, см. схему (5). На первом этапе (до полутора лет) у ребенка, в его (синкретичном) представлении предмета, начинают вычленяться отдельные сенсорные признаки: Форма предмета, его Цвет, Размер и т.д., см. уровень (5b) схемы. С этого момента ребенок уже не путает разнородные прилагательные типа зеленый и маленькиц̆, поскольку в их значениях появляется характеристика признака (Цвет или Размер). Но конкретных признаковых характеристик - ЗЕЛЕНЫЙ или МАЛЕНЬКИЙ - в их значениях еще не содержится, поскольку сами признаки пока остаются синкретичными, не дифференцированными на эти конкретные составляющие. Поэтому ребенок может путать прилагательные зеленый и красныци, маленький и большой.

Затем (второй этап) в каждом из признаков начинают дифференцироваться отдельные значения концепты КРАСНЫЙ, ЗЕЛЕНЫЙ..., БОЛЬШОЙ, МАЛЕНЬКИЙ и др., см. уровень (5с) схемы (5). Теперь они включаются в значения соответствующих прилагательных, и дети перестают их путать. По дан- ным М.Д. Воейковой (2011), семантические ошибки в употреблении цветовых прилагательных в речи детей прекращаются после 2.5 лет (см. также Цейтлин, 1996). Данный факт позволяет заключить, что к этому времени значения признака Цвет у детей дифференцируются и обретают самостоятельный статус (о дальнейшем развитии представления о свойствах предмета и, в частности, о разделении конкретного цвета на оттенки см. Кошелев, 2011).

В полной мере все сказанное относится и к признаку Размер. Об этом косвенным образом свидетельствует тот факт, что ребенок при усвоении слов большой и маленький некоторое время путает их точно так же, как он путает употребление цветообозначающих слов. Примечательно, что повреждение головного мозга у взрослого человека может приводить к регрессии - утрате в ментальном представлении человека некоторых вычленившихся и ставших самостоятельными свойств. Однако способность пользоваться их более архаичными синкретичными коррелятами сохраняется. Например, пациент с поражением коры головного мозга успешно забрасывал мяч в любую из трех коробок, расположенных на разном расстоянии от него, но не мог сказать, какая коробка является ближайшей к нему, а какая - самой далекой (Goldstein, Scheerer, 1941). Выделившееся значение признака Удаление (конкретное расстояние до предмета) у него утратилось, но восприятие расстояния до коробки - как синкретичный компонент ее целостного восприятия - сохранилось. Другая пациентка с поражением базальных отделов височных долей безошибочно схватывала пальцами руки предметы разной величины, но не могла развести большой и указательный пальцы, чтобы показать величину схваченного предмета (Goodale et al., 1991; см. также Чуприкова, 2015).

3.3. Влияет ли язык ребенка на процесс дифференциации? Примерно с 12 месяцев ребенок начинает говорить. В ряде работ (Waxman, Braun, 2005; Fulkerson, Waxman, 2007; Waxman, 2008; Хu, 2002) была установлена тесная связь между именованием и категоризацией не только у 12-месячных, но и у 6- и даже 4-месячных младенцев. А именно: если манипуляции ребенка с игрушками сопровождаются называнием этих игрушек, процесс предметной категоризации у него идет быстрее 5 . Основываясь на этом факте, некоторые исследователи (S. Waxman, F. Xu) стали говорить о доминирующем влиянии речевого развития младенца на его когнитивное развитие: «...Слова служат побудительньми стимулами к образованию категорий» (Waxman, 2008 , p. 101) (курсив автора. - А. К.). Между тем имеются данные, свидетельствующие о самостоятельном, внелингвистическом характере процесса детской категоризации. С. Пинкер, не соглашаясь с доминирующей ролью имен, ссылается на эксперименты, проведенные с обезьянами (макаками резус) (Hauser, 2000; Santos et al., 2002). В них было установлено, что у годовалых детенышей обезьян формируются категориальные

\footnotetext{
5 Категоризация у младенцев ускорялась даже в том случае, когда для обозначения объектов использовались различные псевдослова (звуковые комплексы, лишенные смысла). Напротив, они терпели неудачу, когда оба объекта были названы словом игрушка (a toy), или двумя различными однотонными звуками, или двумя разными эмоциональными (но бессловесными) восклицаниями (Waxman, 2008; см. также Rivera, Zawaydeh, 2006; Xu, 2007).
} 
классы, «как у вас или у меня... хотя обезьяны, конечно, не знали ни слова по-английски» (Пинкер, 2013, c. 174) ${ }^{6}$.

C. Воксмэн (Waxman, 2008) также показала, что слово фиолетовый не может способствовать созданию категории на основе обозначаемого им цвета подобно тому, как конкретное существительное способствует созданию категории на основе обозначаемой им формы. Ни в 12, ни в 14 месяцев классы фиолетовых предметов у младенцев не формировались (это было обнаружено в той же серии экспериментов). ${ }^{7}$ И это при том, что 12-месячные младенцы при различении предметов используют различия в их цвете, во-первых, используют различия в их цвете (Wilcox, 1999) и, вовторых, слыша прилагательное фиолетовый, обращают внимание на фиолетовые объекты (Waxman, 2008).

Данный факт дает основание для следующих двух предположений. Во-первых, в представлении ребенка этого возраста признак Цвет еще не вычленился из синкретической смеси предметных признаков, поэтому конкретные цвета не могут пока концептуализироваться. Во-вторых, в таких условиях (без начальной и сугубо когнитивной дифференциации) лексика воспринимаемые ребенком прилагательные - не способна побудить вычленение соответствующих цветовых значений и начать формирование на их основе новых классов предметов. Воспринимаемые младенцем слова могут ускорять дифференциацию значений лишь для тех признаков, которые уже начали обособляться в результате его сугубо когнитивного развития.

Если же способствующие этому факторы внешней среды (деятельностные и речевые практики) отсутствуют, то развитие концептуальной системы ребенка, повидимому, останавливается на синкретическом уровне. Как мы постараемся показать, именно это и происходит в обыденной жизни племени пираха.

3.4. Цветообозначения в языке пираха. Роль цвета в жизни современных европейцев и индейцев пираха. Как пишет Д. Эверетт, индейцы пираха

«видят цвета вокруг себя так же, как и мы. Однако они не обозначают видимый цвет отдельными словами, которые жестко привязаны к определенным обобщенным представлениям о цвете. Они описывают цвет целыми фразами. <..> ...Их перевод такой: „кровь грязная“ - черный; „оно видит“ или „оно прозрачное“ - белый; „оно как кровь“ - красный; „оно незрелое“ - зеленый» (Эверетт, 2016, с. 132).

Вообще говоря, в таком, аналоговом, именовании цвета нет ничего необычного. В русском языке неред-

\footnotetext{
6 И С. Воксмэн в более поздней статье (Ferry et al., 2010) признала возможность независимого от усвоения имен формирования у ребенка первичных категорий.

7 Ср.: «Как и прогнозировалось, в 14-месячном возрасте младенцы соотносили новые имена исключительно с общими признаками, лежащими в основе категории (но не в основе одинаковых качественных свойств). Напротив, их ожидание в отношении новых адъективов все еще носило общий характер, широко направляя внимание на оба типа обобщающих признаков» (As predicted, 14-month-olds extended novel nouns specifically to category-based (and not property-based) commonalities. In contrast, their expectation for novel adjectives was still quite general, directing attention broadly to both kinds of commonalities (Ibid., p. 105))
}

ки подобные именования: иввет морской волны, рубиновый ивет и пр. Необычно другое: в языке пираха нет непосредственных имен для прототипических цветовых значений типа «красный» и «зеленый». Упомянем в связи с этим кросс-культурную теорию цветовых концептов Б. Берлина и П. Кея (Berlin, Kay, 1969), основанную на понятии базового цветового термина (basic color term) - монолексического имени цвета (red, green и др.), обозначающего такую базовую категорию, прототипический цвет которой одинаков для разных этнических групп. Подытоживая анализ цветовых терминов языка племени дани, проведенный Э. Рош (Хайдер), Дж. Лакофф подчеркивает, что пример прототипического цвета имеет статус «лучшего примера» в такой категории (Лакофф, 2004).

Отсутствие в языке пираха базовых цветовых терминов дает основание предположить, что цветовые значения признака Цвет остаются в ментальных представлениях пираха синкретичными, не разделенными. Казалось бы, у них тот же «лучший пример» прототипа красного цвета - кровь, - что и у нас с вами. Но, по-видимому, этот прототип не обрел в их представлениях самостоятельного статуса, независимого от этого «лучшего примера». Кровь не иллюстрирует центральный красный цвет, а задает его. Прототип в представлении пираха выделяется из спектра «красный» не сам по себе, а только потому, что связан с примером «кровь». Но в таком случае этот прототип и не может получить отдельного монолексического имени.

Почему же трансформация синкретичного признака Цвет в цветовую палитру - набор самостоятельных цветовых прототипов КРАСНЫЙ, ЗЕЛЕНЫЙ и др., свойственный европейскому ребенку, - у ребенка пираха не происходит? Ведь вычленение признака Цвет у него осуществляется. Логика предшествующих рассуждений дает основание предположить, что у детей пираха не наступает второй цикл развития, обеспечивающий дифференциацию различных значений признака Цвет. Причина, как можно предположить, заключается в отсутствии у них необходимого внешнего фактора, прежде всего, соответствующих цветовых практик - обыденных взаимодействий с отдельными цветовыми прототипами.

В самом деле, у детей современных индустриальных обществ имеются по меньшей мере два внешних фактора, стимулирующих дифференциацию конкретных цветов. Во-первых, это активная деятельность ребенка по выбору предмета по его цвету. Цвет необычайно информативен в их мире, изобилующем артефактами с произвольными цветами. У ребенка может быть несколько одинаковых игрушек, предметов одежды и обуви, конфет, шахматных фигур и пр., различающихся только цветом. Цвет также нередко несет конвенциональную символическую функцию (светофор). Кроме того, рисуя цветными карандашами и акварельными красками, ребенок сам выбирает цвет рисуемого объекта. Во-вторых, это цветообозначающие прилагательные красныц̆, зеленый и др., которыми окружающие люди постоянно называют как цвета видимых детьми предметов, так и фрагменты их многоцветной раскраски: в красную полоску, в зеленьй горошек и пр. 
В мире ребенка пираха все иначе. Их окружает природный мир со своими естественными и неизменными (или закономерно меняющимися) красками. Артефактов, имеющих случайный цвет, очень мало (простейшие предметы одежды, инструменты и подоб.). Да и их индейцы не выбирают, а получают (выменивают) более или менее случайным образом. И даже в тех случаях, когда цвет является информативным, например, зеленый цвет свидетельствует о незрелости, он, как правило, не является единственным критерием. Если в магазине могут продаваться, скажем, зеленые бананы, то у индейцев пираха плоды собираются лишь в созревшем состоянии, когда они утрачивают зеленый цвет. И незрелость плодов видна не только по их цвету, но и по другим признаками: цвет и состояние листьев дерева, спелость других плодов, созревающих одновременно с ними и пр. Кроме того, у индейцев пираха совершенно отсутствует склонность к рисованию, включая традицию наносить на свое тело символические узоры (Эверетт, 2016). Наконец, отсутствует и второй - лексический - фактор, поскольку в языке пираха нет монолексических коррелятов прилагательных красныц̆, зеленыц̆ и подоб., напрямую именующих цвета.

Таким образом, есть основания предполагать, что отсутствие цветовых практик в обыденной деятельности индейцев пираха препятствует дифференциации у их детей синкретичного спектра признака Цвет, его трансформации в цветовую палитру - набор отдельных прототипов - концептуальных значений для цветообозначающих имен. А потому и сами имена не могут появиться. И напротив, возникновение таких прототипов стимулирует образование для них лексических имен.

Логика проведенных рассуждений подтверждается следующим фактом. В европейских языках существует множество аналоговых обозначений для называния различных цветовых оттенков: аметистовыцй (amethyst), бронзовыц (bronze), медный (copper), морковный (carrot), каштановый (chestnut), шоколадный (chocolate), янтарныци (amber). Как мы видим, они совершенно аналогичны цветообозначениям в пираха или, скажем, в языке вальбири: yalyu-yalyu, в буквальном смысле 'кровь-кровь', а фактически 'выглядит как кровь', yukuri-yukuri ('трава-трава', или 'выглядит как трава после дождя') и подоб. (Wierzbicka, 2008, p.410). Разумно полагать, что эти обозначения и объясняются аналогично: в обыденной жизни европейца нет практик работы с этими оттенками. Поэтому они и не концептуализировались в его цветовой палитре.

Однако в сообществах современных художников или модельеров, в деятельности которых эти оттенки цветов играют важную роль, они могут выделиться в самостоятельные прототипы, пополняя тем самым набор основных цветов. И тогда их имена могут обрести статус базовых терминов. К примеру, в среде модельеров могут использовать название «фисташковый» (грязновато-зеленый) цвет непосредственно, не зная, что исходно это цвет зерен фисташковых орехов. И тогда прилагательное фисташковый станет базовым термином цвета для международного сообщества модельеров.
3.5. Лексические показатели времени. Двухэтапный процесс усвоения детьми значений цветообозначающих прилагательных характерен и для других групп слов, обозначающих различные (альтернативные) значения какого-то признака (общего свойства). Например, ранее мы уже отмечали, что дети путают показатели времени вчера/завтра: Mь завтра ходили в лес (Настя, 2 года 4 месяца), Я к бабушке вчера поеду (Воейкова, 2011, с. 115-116, 173). Объяснение этих ошибок аналогично: дифференциация признака «Ненастоящее время» от признака «Настоящее время» у ребенка уже произошла, а различение его значений - 'прошедшее-вчера' и 'будущее-завтра' - еще нет. Однако она не заставит себя ждать, поскольку мотивируется каждодневным опытом ребенка - суточным циклом, в котором эти понятия строго отделяются от «сегодня», и лексикой (он постоянно слышит слова вчера и зав$m p a)$. Но в ментальном мире индейцев пираха соответствующие понятия отсутствуют. Их жизнь не делится на суточные циклы, ср.:

«Пираха спят урывками (от пятнадцати минут до двух часов) и днем, и ночью. Всю ночь в селении стоит гул голосов. <...> Поскольку в разные часы дня и ночи ловится разная рыба, индейцев можно застать за рыбалкой круглые сутки. Это значит, что день и ночь не так различны между собой, как у нас, - разве что видимостью. Индейца можно увидеть за рыбалкой хоть в три утра, хоть в шесть, хоть в три часа дня. <...> Если ктото принесет улов в три часа ночи, то тогда же рыбу и съедят: все встанут тут же, как только рыболов вернется. <...> Индейцы встали (они пили кофе в хижине Д. Эверетта. - А. К.) и ушли на рыбалку: пришла их очередь, потому что другая смена только что вернулась в селение и можно было взять лодки»(Эверетт, 2016, с. 92, 93, 286).

Поэтому в языке пираха в принципе не может быть прямых коррелятов столь привычных нам лексических показателей времени, как вчера, сегодня, завтра, утро, вечер, неделя, месяи и подоб. В то же время в этом языке имеются другие показатели времени, по своей наглядности вполне соответствующие аналоговым цветообозначениям пираха: hisó «в течение дня ('на солнце')», hisóogiái «полдень ('солнце большое/сильное')», piiáiso «низкая вода вре́менная», piibigaíso «высокая вода вре́менная», kahai'aíi 'ogiíso «полная луна вре́менная», hibigíbagááiso «заход/восход», 'ahoakohoaihio "раннее утро ('перед восходом')» (Everett, 2005, p. 631). Все они суть абсолютные характеристики периодов времени, доступные прямому распознаванию по внешним признакам. В языках среднеевропейского стандарта есть и относительные, и абсолютные показатели времени. Например, слова ympo (morning) и вечер (evening) обозначают относительные периоды времени (в ряду периодов: «ночь», «утро», «день», «вечер») и не имеют прямых визуальных маркеров. А показатели восход/ заход (sunrise/sunset) называют визуально идентифицируемые периоды времени. Это же верно и в отношении русских показателей раннее утро и поздний вечер, ср. также пары: время прилива - piibigaíso «вы- 
сокая вода вре́менная», время отлива - piiáiso «низкая вода вре́менная», полдень - hisóogiái «полдень (солнце большое/сильное)».

Итак, в языке пираха есть только абсолютные темпоральные показатели, а в языках среднеевропейского стандарта имеются и абсолютные, и относительные показатели.

3.6. Счет и счетные слова. Отмечая отсутствие числительных в языке пираха, Эверетт пишет:

«Сначала я думал, что в языке пираха есть слова „один“, „два“ и „много“, что не редкость среди языков мира. Но потом я понял, что те слова, которые я и предыдущие исследователи принимали за числительные, означают только относительно большее или меньшее количество. <...> ...Я увидел, что они используют слово, которое я принимал за „два“, когда говорят о двух маленьких рыбах или об одной умеренно крупной рыбине, что подтверждало мою мысль о том, что эти „числа“ просто указывают на относительную величину: две маленькие или одна средняя рыба примерно равны по объему, но в любом случае меньше, чем крупная рыбина, что и заставляет использовать специальное „числительное“» (Эверетт, 2016, с. 129-130).

Это наблюдение Эверетта позволяет предположить, что у индейцев пираха сформировались лишь первичные представления о категории «количество»: hói 'небольшое количество', hoí 'большое количество', xogió 'все или почти все' и др. Но их дальнейшая дифференциация на конкретные множества - значения признака Количество, которые обозначаются счетными словами, - у них не наступила. Этот факт кажется совершенно закономерным, поскольку в своей повседневной жизни индейцы пираха вообще не используют счет, ср.: «Когда я стал наблюдать за ними пристальнее, я увидел, что они никогда не считают ни на пальцах, ни на других частях тела, ни с помощью счетных предметов» (там же).

Генетически обусловленные задатки способности к счету у человеческих младенцев, безусловно, есть (см., например, Иванов, 2008), но внешний фактор отсутствие практики счета - тормозит ее развитие. Заметим, что именно отсутствие такой практики (а не счетных слов) служит главным свидетельством отсутствия у пираха концептуализаций конкретных количеств (множеств), (см. также Frank et al., 2008, где экспериментально показывается, что счетные слова не меняют наши ментальные представления о числе, но служат инструментом для работы с большими множествами). Например, племя австралийских аборигенов вальбири пользуется счетом, несмотря на то что система числительных в их языке крайне скудна (Эверетт, 2016). Эта, казалось бы, парадоксальная ситуация вполне объяснима. Она возникает при жестовом счете, использующем пальцы рук (и ног или других частей тела), ср.:

«В развитии коммуникации ребенка и в реконструированных праязыках многих семей языков пальцевые жесты выступают в качестве символов соответствующих чисел, что можно считать универсальной чертой естественных языков, где, как правило, числительное 5 означало некогда „одна рука“, 10 - „обе руки“ и т. п. <...> ...Нейропсихологи приходят к выводу о том, что язык и математика не зависят друг от друга, и к звучащему на лад Платона утверждению, согласно которому понятие числа возникает раньше, чем соответствующее ему слово [Varley et al. 2005; Brannon 2005; Dehaene 2007] <...> Можно предположить, что это раннее понятие числа сперва воплотилось в жесте и потом лишь - в слове» (Иванов, 2008, c. 5-7).

Необходимость счетной практики подтверждается анализом счетных слов у племени охотников-собирателей мундуруку (Mundurukú), также обитающем в бассейне Амазонки. Как отмечается в статье (Ріса et al., 2004), у них больше счетных слов, чем у пираха: от одного до пяти. Однако индейцы мундуруку словами «три», «четыре» и «пять» называют не только точные, но близкие к ним количества, поскольку выбирают эти слова на основе интуитивных оценок, без точного подсчета (там же). При этом некоторые из них умеют считать точно (медленно и невербально с помощью пальцев руки или ноги). Однако они редко этим пользуются, поскольку не имеют (как и пираха) практической потребности в точном счете (там же). О связи счета и счетных слов см. также в статье А. А. Кибрика (2018) в настоящем выпуске журнала.

Подчеркнем: процесс усвоения различных количеств детьми также складывается из двух этапов. Сначала в их ментальных представлениях вычленяется признак Количество, а затем - его значения - конкретные множества. Об этом свидетельствует процесс усвоения ребенком счетных слов, совершенно аналогичный процессу усвоения цветообозначающих слов. Первоначально в детских высказываниях «числительные появляются перед именем существительным, но в целом конструкция лишь напоминает сходные по функции высказывания взрослых, так как реальное количество предметов не соответствует тому, которое названо» (Воейкова, 2011). Лишь позднее ребенок научается правильно называть требуемое количество.

3.7. Отсутствие страдательного залога (пассива). Согласно Д. Эверетту, культура индейцев пираха базируется на принципе непосредственности восприятия. В соответствии с этим принципом, достоверным знанием для индейцев являются знания о событиях, полученные ими в результате непосредственного наблюдения или личного опыта, а также рассказанные очевидцами. Практически все интересы и все внимание индейцев фокусируется на том, что происходит «здесь и сейчас», ср.:

«...Пираха не хранят пищу, не планируют вперед больше чем на день, не обсуждают далекое будущее или прошлое - они сосредоточены на том, что есть сейчас, на непосредственно воспринимаемом мире. <...> Пираха просто концентрируются на том, что непосредственно их окружает... Им не нужна истина как некая извечная реаль- 
ность. Эта идея не имеет никакой ценности для них. Истина для них - это поймать рыбу, грести в лодке, смеяться вместе с детьми, любить своего брата, умереть от малярии» (Эверетт, 2016, c. 143,295$)$.

По мнению Эверетта, этот принцип предопределяет не только бытовые и культурные стороны жизни индейцев (бедность их ритуалов и устного фольклора, отсутствие художественного вымысла и т. д.), но и специфические черты их языка, в частности отсутствие рекурсии (см. Futrell et al., 2016).

Принимая в целом эту точку зрения, приведем один согласующийся с ней пример. Покажем, что отсутствие пассива в языке пираха связано с принципом непосредственности восприятия. Для обоснования этого тезиса мы будем опираться на когнитивный подход к толкованию залоговых значений (подробнее о нем см. Кошелев, 2016). Его сущность состоит в том, чтобы представлять видимую, наблюдаемую ситуацию посредством когнитивных компонентов, подобных компонентам, выделенным Л. Талми (Фигура, Путь и др.), описывающим ситуацию движения.

Приводимый ниже анализ основан на русскоязычном материале и носит иллюстративный характер. Его цель - показать, что значение страдательного залога весьма абстрактно. В отличие от значения действительного залога, непосредственно отражающего наблюдаемое действие (Агенс - главный участник действия - назван существительным-подлежащим и пр.), оно отражает весьма специфическую интерпретацию этого действия (существительным-подлежащим назван пассивный участник действия, а Агенс - существительным в инструментальном значении). Ввиду этого, напрашивается вывод о том, что у индейцев пираха потребность в такой косвенной интерпретации воспринимаемого действия могла отсутствовать. А стало быть, и значение пассива оказалось не востребованным.

Основным далее будет общее понятие действия. Действием мы называем наблюдаемые однотипные изменения, происходящие с объектом. Действие (эти изменения) может порождаться самим объектом (его внутренней энергией) - тогда оно называется независимым, и действием другого объекта - тогда это зависимое действие.

Залоговое значение глагола указывает на тип действия (независимое или зависимое), происходящего с субъектом действия - референтом подлежащего. Актив (действительный залог) обозначает независимое действие субъекта, а пассив (страдательный залог) зависимое действие субъекта.

В предложении

\section{(6) Шофер моет машину}

с шофером происходит независимое действие (глагол моет имеет активный залог), а в предложении

\section{(7) Машина моется шобером}

с машиной (субъектом глагола) происходит зависимое действие (глагол моется имеет пассивный залог).
Для пояснения этих определений рассмотрим подробнее ситуацию, обозначаемую предложением (6). В ней переходный глагол моет обозначает не одно «переходное» действие, а трехчленную конструкцию: два действия, связанных каузальным отношением. Первое действие (однотипные изменения) происходит с шофером: «он мочит тряпку в ведре с водой, водит мокрой тряпкой по поверхности машины и пр.». Это - независимое действие, поскольку оно порождается энергией (активностью) шофера. Второе действие (однотипные изменения) происходит с машиной: «она становится чище». Это - зависимое действие, порождаемое другим, первым действием. Итак, предложение Шофер моет машину обозначает следующую ситуацию:

(8) ситуация «шофер-машина» =

«с шофером происходит независимое действие (он мочит тряпку в ведре с водой, водит мокрой тряпкой по поверхности машины и пр.)»,

\section{ПОЭТОМУ}

«с машиной происходит зависимое действие (машина становится чище)».

Рассмотрим теперь предложение (7) Машина моется шобером. Как ни странно, оно описывает ту же ситуацию (8), в которой шофер по-прежнему - активный объект, независимое действие которого порождает зависимое действие, происходящее с машиной, - она становится чище. Этот вывод диктуется нашими знаниями об описываемой ситуации. И тем не менее значение этого предложения существенно отлично от значения предложения (6). Как нетрудно догадаться, различие заключается в разных трактовках ситуации (8), даваемых этими предложениями. В предложении Шофер моет машину главным участником ситуации выбран Агенс - шофер (референт подлежащего), а главным его действием - то, что он осуществляет с Пациенсом (машиной) (он мог одновременно с этим действием курить, разговаривать с приятелем и т.д.). Эта трактовка полностью соответствует принципу непосредственности восприятия, поскольку главным объектом описания выбран внешне наиболее активный и заметный участник ситуации, а главным его действием - действие, представляющее наибольшие видимые изменения, происходящие в ситуации, и потому обращающее на себя внимание (мочит тряпку в ведре с водой и т.д.). Важную роль здесь также играет контакт действующего шофера с машиной. Этот контакт манифестирует каузальное отношение между действием шофера и действием, происходящим с машиной.

Замечание. В серии проведенных А. Лесли экспериментов (Leslie, 1982; 1984) трехмесячные младенцы наблюдали столкновение шаров. Если красный шар, подкатившись вплотную к зеленому шару, останавливался, а зеленый шар немедленно приходил в движение («прямой толчок»), они не выражали никакого удивления (быстро переставали обращать внимание на это действие). Если же красный шар останавливался, чуть-чуть не доходя до зеленого шара, а последний начинал движение («толчок без столкно- 
вения»), то младенцы были удивлены таким действием. Младенцы также удивлялись, когда красный шар подходил вплотную к зеленому, а последний начинал движение на сразу, а с некоторой задержкой («отсроченный толчок»). Эти и другие эксперименты (см. о них Субботский, 2007) показали, что с самого раннего возраста дети трактуют контакт между двумя действующими объектами как свидетельство каузального отношения между их действиями.

Таким образом, предложение Шофер моет машину дает непосредственное описание воспринятой ситуации, использующее ее визуальные признаки. В предложении Машина моется шофером акценты расставлены совершенно иначе. Главным участником ситуации названа машина (прежний Пациенс) пассивный объект, не привлекающий внимания, а главным действием - происходящие с машиной зависимые изменения - «она становится чище». При этом активный участник ситуации - шофер (прежний Агенс) именуется существительным в творительном падеже, то есть трактуется как инструмент, непосредственно порождающий эти изменения, но не имеющий собственной активности, ср. Машина моется тряпкой. Поэтому этот инструмент вообще может не упоминаться, ср. Машина моется. Как мы видим, эта трактовка дается вопреки непосредственно воспринимаемым характеристикам участников ситуации. Что же могло ее мотивировать? По-видимому, включение ситуации (4) в более широкий контекст, диктующий интерес к другим, не связанным с первичным восприятием, характеристикам. Прежде всего, это интерес к пассивному объекту и его изменениям, вызванным внешним действием, причем неважно чьим. Такая трактовка отвечает ситуациям, в которых действие недоступно прямому наблюдению, ср. Ваша машина моется (она в мойке), или растягивается на длительный срок - и неясно, что с объектом происходит в данный момент: Дом строится (при непосредственном восприятии дома это не всегда можно понять).

Подобные трактовки далеко выходят за пределы принципа непосредственности восприятия, царящего в мире индейцев пираха.

Сходным, но более сильным образом принцип непосредственности восприятия действует у детей. Л.С. Выготский рассказывает об эксперименте, который его сотрудница провела с двухлетними детьми. Они без труда повторяли отвлеченные фразы Курица идет, Коко идет, Собака бежит. Но сказать Таня идет, глядя на сидящую перед ними Таню, они не могли (Выготский, 2004, с. 136).

Конечно, восприятие индейцев не замыкается в рамках этого принципа. Но для его преодоления необходимо, чтобы в их обыденной жизни стали появляться соответствующие ситуации. А пока их нет, можно предположить, что у индейцев просто нет потребности в использовании пассивных конструкций (в п. 3.2 мы рассмотрели условия, в которых такие ситуации и описывающие их пассивные конструкции могут появиться).
Подведем итог. Проведенный анализ показал, что принцип непосредственности, или синкретичности восприятия сохраняется и в современных индустриальных социумах. Поэтому в европейских языках имеются аналоговые именования цветов типа аметистовыц (amethyst), бронзовый (bronze), морковныцй (carrot), каштановый (chestnut), янтарный (amber), абсолютные темпоральные показатели типа восход, заход (sunrise, sunset), называющие визуально идентифицируемые периоды времени, действительный залог, непосредственно отражающий наблюдаемое действие. Однако, в результате развития индустриальных социумов, у их представителей сформировался в рассмотренных сферах и другой принцип - опосредованности, или системности восприятия. Благодаря ему в языках этих социумов появились цветообозначающие имена типа красныц̆, зеленый (red, green), относительные показатели времени типа ympo, вечер (morning, evening), не имеющие прямых визуальных маркеров, пассив и другие залоговые значения, отражающие контекстные интерпретации видимых действий.

Из сказанного вовсе не следует, что у индейцев пираха принцип системности восприятия отсутствует. В их практической жизни огромную роль играют джунгли. Индейцы знают множество видов деревьев и трав, их лечебные и другие свойства, а также приемы их обработки и использования. По-видимому, в этом, а также в других подобных аспектах, ментальные представления действительности у индейцев гораздо более дифференцированы и системны, чем у членов индустриальных обществ. Поэтому в языке пираха имеется множество конкретной лексики, обозначающей эти растения, их свойства и действия с ними. А это, как мы теперь можем утверждать, есть следствие принципа системности восприятия мира джунглей.

3.8. Об универсальности человеческих концептов. Проведенные выше рассуждения позволяют утверждать, что концепты цвета (ЗЕЛЕНЫЙ, КРАСНЫЙ...), размера (БОЛЬШОЙ, МАЛЕНЬКИЙ...), счета (ОДИН, ДВА, ТРИ...) и др. никак не могут претендовать на статус универсальных человеческих концептов.

Коснемся в этом плане дискуссии об универсальности цветовых категорий. Как мы уже упоминали, Б. Берлин и П. Кей (Berlin, Kay, 1969) утверждают, что английские базисные цветовые наименования black, white, red, yellow, green, blue, brown, purple, pink, orange и gray задают базовые категории, центральные прототипы которых одинаковы для разных этнических групп. И хотя многие языки содержат меньшее количество имен для базовых категорий, люди способны формировать все такие категории. А. Вежбицкая придерживается иной точки зрения (Wierzbicka, 2005; 2008). Основываясь на том факте, что в некоторых языках, например в языке австралийских аборигенов вальбири, нет ни слова извет, ни базисных имен для основных цветов, она полагает, что цветовые категории не относятся к числу человеческих универсалий. Вежбицкая признает, что все люди живут в многоцветном мире. Но не все воспринимают цвета концептуально. У носителей языков, не имеющих слова цвет, вопрос «Какой это цвет?» не может быть задан и, по-видимому, не возникает. А значит, люди не могут и думать о цвете. 
Для Вежбицкой вопрос об универсальности концепта ЦВЕТ принципиален. Отвечая на него отрицательно, она не включает этот концепт в число своих универсальных семантических примитивов. Не соглашаясь с ее логикой, П. Кей отмечает, что в ряде языков отсутствуют слова размер, большой и маленький, число, количество, один, два и др. Однако, несмотря на это, Вежбицкая относит концепты БОЛЬШОЙ и МАЛЕНЬКИЙ, ОДИН и ДВА к универсальным семантическим примитивам (Кау, 2015).

Не имея возможности вдаваться здесь в детали дискуссии (ответ Вежбицкой см. в работе Wierzbicka, 2008), заметим лишь, что данные выше объяснения разрешают эту коллизию. Из них следует, что цветовые категории можно считать универсальными лишь потенциально - в том смысле, что выделенность признака Цвет, по-видимому, имеет генетическую обусловленность. Что же касается степени развития значений этого признака, то она определяется исключительно воздействием извне - влиянием повседневной практической деятельности социума. В полной мере все сказанное относится и к признаку Размер, см. п. 3.2.

Замечание. Из приведенных рассуждений следует, что понятие «лексическая/грамматическая универсалия» является относительным. Оно применимо не ко всем языкам, а к подмножествам языков, находящихся на одной стадии эволюции, иначе говоря, к парам «Язык-Социум», в которых социумы имеют примерно одинаковый уровень развития. Сказанное следует учитывать и при обращении к стословному списку Сводеша, в который в качестве базовых слов входят прилагательные зеленый, желтый, красный, большой, маленький, числительные один, два.

В этом же ключе следует, как нам кажется, трактовать спор между Д. Эвереттом и генеративистами (Everett, 2009; Nevins et al., 2009a, b; Futrell et al., 2016; Everett, 2008 / Эверетт, 2016) об универсальности рекурсии. Этой теме посвящен целый ряд исследований (см., в частности, Никулин, 2018 в настоящем выпуске журнала). Не имея возможности включаться здесь в эту дискуссию, отметим лишь свою солидарность с тезисом о существенном различии бесписьменных и письменных языков, которое следует учитывать при обсуждении языковой рекурсии (см. статьи Бурлак, 2018; Кибрик, 2018 в настоящем выпуске журнала).

3.9. Итоговые замечания. Приведенный в данном разделе анализ иллюстрирует огромное влияние, оказываемое прогрессом этногруппы (цивилизационным компонентом ее культуры, согласно Э. Сепиру) на развитие содержательной составляющей языка его лексических и грамматических средств. Тем самым получили объяснение те механизмы, посредством которых, как писал Сепир, быстрое развитие западноевропейской культуры на протяжении последних 2000 лет сопровождалось «необыкновенно быстрыми языковыми изменениями», см. цитату в п. 1.2.

Что же касается положения Д. Эверетта о непосредственном влиянии культуры на строй языка, то нам не удалось найти ему подтверждения. Более того, есть основания для сомнений в его справедливости.
В самом деле, как мы показали выше, важнейшим фактором развития языка прогрессирующего социума служат постоянно возникающие в нем новые профессиональные языки. Однако каждый такой язык, при определении значений своих новых терминов, новых метафорических и идеоматических выражений, неизбежно использует синтаксис базового (обыденного) языка социума. Конечно, в новом языке могут появляться специальные, не употреблявшиеся ранее синтаксические конструкции типа математической конструкции тогда и только тогда. Но все они должны быть синтаксически корректными, иначе их просто нельзя будет однозначно понять ${ }^{8}$ Ввиду этого, естественно полагать, что на продвинутых этапах прогресса социума его культура (по крайней мере, ее цивилизационный компонент) не способна модифицировать синтаксис языка, в частности, изменять порядок слов предложения (SVO, SOV и др.), о котором говорил С. Пинкер, см. п. 1.1. Таким образом, в этом аспекте мы разделяем точку зрения Сепира, высказанную им в 1933, но не в 1911 году, см. п. 1.2. Притом что во всех остальных аспектах влияние культуры на язык (но не наоборот) не вызывает сомнений.

Замечание. Впрочем, нельзя исключить правоту Эверетта, утверждающего, что культура индейцев пираха влияет на строй их языка. Это племя, по-видимому, близко к тому начальному уровню прогресса, на котором, согласно Сепиру (1911), такое влияние возможно (см. цитату, приведенную в п. 1.2). Рассмотрим чисто гипотетически, как такое влияние могло бы осуществляться применительно к порядку слов в предложении. В самом деле, порядок слов предложения можно рассмотреть как указание на степень информативности его главных членов. К примеру, SVO указывает, что первым по информативности является подлежащее, вторым - сказуемое и третьим - прямое дополнение. Но это, по существу, означает, что в этноспецифичном представлении ситуации наиболее информативным ее участником является Агенс, на втором месте стоит Действие, а на третьем - Пациенс. Разумно предположить, что данная этноспецифика (порядок информативности участников ситуации) лежит в основе картины мира племени и может различаться у разных племен. А поскольку есть основания полагать, что представление ситуации первично относительно языка (см. об этом Кошелев, 2017), отвечающий этому представлению порядок слов в языках этих племен также будет различаться. ${ }^{9}$

\footnotetext{
8 Это утверждение фактически означает, что все профессиональные языки являются развившимися подъязыками обыденного языка социума.

9 Эта гипотеза согласуется с позицией Г. Пауля, считавшего порядок слов вторым по важности (из семи) языковым средством выражения связных человеческих представлений, ср.: «Для выражения связи представлений в языке существуют следующие средства: 1) простое соположение слов; 2) порядок слов... 6) служебные слова... 7) флективное изменение слов <...> Само собой разумеется, что из названных средств выражения связи представлений два последних могли сложиться лишь постепенно, в ходе длительного исторического развития, тогда как первые пять уже с самого начала находились в распоряжении говорящего» (Пауль, 1960, с. 145-146).
} 
Если удастся обнаружить подтверждения этому предположению в типологических данных, то можно будет показать, что на начальном уровне прогресса племени его культура может влиять на строй языка, как и предполагал Сепир в своем докладе 1911 года.

Проведенный выше анализ также показал, что развитие человека обусловлено развитием составляющих его подсистем: мышления (ментальных репрезентаций действительности), действий (деятельности) и языка. А они развиваются не независимо друг от друга, а исключительно в рамках тесного взаимодействия и взаимной поддержки. Заметим, что это положение не является общепринятым. Например, Н. Хомский придерживается альтернативной позиции:

\section{«С биолингвистической точки зрения язык мож- но представлять как „орган тела“ (наравне со зрительной, пищеварительной или иммунной системами). Подобно им, язык - субкомпонент сложного организма, обладающий значительной внутренней целостностью, так что изучать его нужно отдельно от его сложных взаимодействий с другими системами в жизненном цикле орга- низма» (Хомский, Бервик, 2018, с. 89).}

В заключение мне хотелось бы выразить восхищение широтой исследовательской и просветительской деятельности Д. Эверетта, который открыл нам столь необычный мир и язык индейского племени пираха и осмелился публично противопоставить свои взгляды - итог многолетнего профессионального изучения языка и культуры пираха - самому мощному направлению современной теоретической лингвистики. Следуя модели (1a), можно с уверенностью констатировать весьма высокий уровень его деятельностного развития.

\section{Литература} 1985.

Бауэр Т. Психическое развитие младенца. М.: Прогресс,

Бодуэн де Куртенэ И.А. Избранные труды по общему языкознанию. Т. І-ІІ // М.: Изд-во АН СССР. 1963. Т. 1. С. 384. Бурлак С. А. Язык пираха и разговорная речь // Российский журнал когнитивной науки. 2018. Т. 5. №1. С. 22-26.

Вендлер 3. О слове good // Новое в зарубежной лингвистике. Вып. Х. М.: Прогресс, 1981, С. 531-554.

Воейкова М.Д. Ранние этапы усвоения детьми именной морфологии русского языка. М.: Знак, 2011.

Выготский Л.С. Психология развития ребенка. М.: Смысл, Эксмо, 2004.

Иванов В.В. Об эволюции переработки и передачи информации в сообществах людей и животных // Вопросы языкознания. 2008. №4. С. 3 - 14 .

Кибрик А. А. Тирания чужого ума // Российский журнал когнитивной науки. 2018. Т. 5. №1. С. 27-32.

Кошелев А. Д. О структурном и генетическом сходстве лексических и грамматических значений (когнитивный анализ глагольной переходности и залога) // Изв. РАН. Серия литературы и языка. 2016. T.75. № 3. C.19-39. URL: http://izvoifn.ru/articles/206/public/206-529-1-PB.pdf.

Кочелев А.Д. В поисках универсальной схемы развития // Интеграционно-дифференционная теория развития / Под ред. Н.И. Чуприковой, А.Д. Кошелева. М.: Языки славянских культур, 2011. С. 217-234. URL: www.akoshelev.net.
Кочелев А.Д. Очерки эволюционно-синтетической теории языка. М.: ЯСК, 2017. URL: https://independent.academia. edu/AlexeyKoshelev.

Лакофф Д. Женщины, огонь и опасные вещи. Что категории языка говорят нам о мышлении. М.: Языки славянской культуры, 2004.

Марр Н.Я. Избранные работы. В 5 т. Т. І. Л.: Изд-во АН CCCP, 1933.

Марр Н. Я. Избранные работы. В 5 т. Т. ІІ. Л.: Изд-во АН CCCP, 1936

Морган Л.Г. Древнее общество, или Исследование линий человеческого прогресса от дикости через варварство к цивилизации. Л: Издательство института народов севера ЦИК СССР, 1935.

Никулин А.В. Принцип непосредственности восприятия: критическая оценка // Российский журнал когнитивной науки. 2018. Т. 5. №1. С. 81-95.

Пауль Г. Принципы истории языка. М.: Издательство иностранной литературы, 1960.

Пинкер С. Субстанция мышления: язык как окно в человеческую природу. М.: Книжный дом «Либроком», 2013.

Пинкер С. Язык как инстинкт. М.: Едиториал УРСС, 2004.

Розенгарт-Пупко Г.Л. Речь и развитие восприятия в раннем возрасте. М.: Учпедгиз, 1948.

Розенгарт-Пупко Г. Л. Формирование речи у детей раннего возраста. М.: Учпедгиз, 1963.

Сепир Э. Избранные труды по языкознанию и культурологии. М.: Прогресс, 1993.

Сеченов И. М. Избранные произведения. Т. 1. Физиология и психология. М.: АН СССР, 1952.

Соловьев В. С. Сочинения в 2 т. Т. 2.. М.: Мысль, 1988.

Спенсер Г. Собрание сочинений. Т. 1. Основания биологии. СПб.: Акц. Общ. печатного дела «Издатель», 1899.

Цейтлин С.Н. Усвоение ребенком прилагательных // Детская речь: норма и патология: Межвуз. сб. науч. трудов. Самара: Изд-во Самарского гос. ун-та, 1996. С. 4 - 15.

Цейтлин С. Н. Очерки по словообразованию и формообразованию в детской речи. М.: Знак, 2009.

Чуприкова Н. И. Умственное развитие. Принцип дифференциации. СПб.: Питер, 2007.

Чуприкова Н.И. Психика и психические процессы: система понятий общей психологии. М.: Языки славянской культуры, 2015.

Эверетт Д. Не спи - кругом змеи! Быт и язык индейцев амазонских джунглей. М.: ЯСК, 2016.

Andrick G.R., Tager-Flusberg H. The acquisition of colour terms // Journal of Child Language. 1986. Vol.13. No.1. P.119- 137. doi:10.1017/s0305000900000337

Berlin B., Kay P. Basic color terms: Their universality and evolution.Berkeley: University of California Press, 1969. doi: $10.2307 / 2798490$

Blackwell A.A. Acquiring the English adjective lexicon: Relationships with input properties and adjectival semantic typology // Journal of Child Language. 2005. Vol.32. No.3. P.535-562. doi:10.1017/s0305000905006938

Bornstein M. H. Colour-name versus shape-name learning in young children // Journal of Child Language. 1985. Vol.12. No.2. P.387 - 393. doi:10.1017/s0305000900006498

Brannon E.M. The independence of language and mathematical reasoning // Proceedings of the National Academy of Sciences of the USA. 2005. Vol.102. No.9. P.735 - 740. doi:10.1073/ pnas.0500328102

Dehaene S. A few steps toward a science of mental life // Mind, Brain and Education. 2007. Vol.1. No.1. P.28-47. doi:10.1111/j.1751-228x.2007.00003.x

Dixon R.M.W. Adjectives classes in typological perspective // Adjective classes: A cross-linguistic typology / R.M.W. Dixon, A.Y. Aikhenvald (Eds.). Oxford: Oxford University Press, 2004. P. $1-49$.

Dixon R.M.W. Where have all the adjectives gone? And other essays in semantics and syntax. Berlin: Mouton, 1982. doi:10.1515/9783110822939 
Ebeling K.S., Gelman S.A. Flexibility in semantic representations: Children's ability to switch among different interpretations of "big" and "little" // Papers and reports on child language development. Vol.29. Stanford, California: Department of Linguistics, Stanford University, 1990. P.38-46.

Everett $D$. Pirahã culture and grammar: A response to some criticism // Language. 2009. Vol.85. No.2. P.405 - 442. doi:10.1353/ lan. 0.0104

Everett D.L. Cultural constraints on grammar and cognition in Pirahã: Another look at the design features of human language // Current Anthropology. 2005. Vol.46. No.4. P.621 - 646. doi:10.1086/431525

Ferry A., Hespos S., Waxman S. Categorization in 3- and 4-month-old infants: An advantage of words over tones // Child Development. 2010. Vol.81. No.2. P.472-479. doi:10.1111/j.1467-8624.2009.01408.x

Fulkerson A.L., Waxman S.R. Words (but not Tones) facilitate object categorization: Evidence from 6- and 12-montholds // Cognition. 2007. Vol.105. No.1. P.218-228. doi:10.1016/j. cognition.2006.09.005

Futrell R., Stearns L., Everett D.L., $\quad$ PiantadosiS.T., Gibson E. A corpus investigation of syntactic embedding in Pirahã // PLoS One. 2016. Vol.11. No.3. P.e0145289. doi:10.1371/ journal.pone.0145289

Gasser M., Smith L. Learning nouns and adjectives: a connectionist account // Language and Cognitive Processes. 1998. Vol.13. No.2/3. P.269 - 306. doi:10.1080/016909698386537

Gentner D. Why we're so smart // Language in mind: Advances in the study of language and thought / D. Gentner, S. Goldin-Meadow (Eds.). Cambridge, MA: MIT Press, 2003. P. $195-235$.

Goldstein K., Scheerer M. Abstract and concrete behavior an experimental study with special tests // Psychological Monographs. 1941. Vol.53. No.2. P.i-151. doi:10.1037/h0093487

Goodale M.A., Milner A.D., Jakobson L.S., Carey D.P. A neurological dissociation between perceiving objects and grasping them // Nature. 1991. Vol.349. No.6305. P.154-156. doi: $10.1038 / 349154 \mathrm{a} 0$

Hauser M.D. Wild minds: What animal really think. N.Y.: Henry Holt, 2000.

Kay P. Universality of color categorization // Handbook of color psychology / A.J. Elliot, M.D. Fairchild, A. Franklin (Eds.). Cambridge: Cambridge University Press, 2015. P.245-258.

Landau B., Smith L. B., Jones S. S. The importance of shape in early lexical learning // Cognitive Development. 1988. Vol.3. No.3. P.299-321. doi:10.1016/0885-2014(88)90014-7

Leslie A.M. The perception of causality in infants // Perception. 1982. Vol.11. No.2. P.173 - 186. doi:10.1068/p110173

Leslie A.M. Spatiotemporal continuity and the perception of causality in infants // Perception. 1984. Vol.13. No.3. P.287-305. doi:10.1068/p130287

Markson L., Diesendruck G., Bloom P. The shape of thought // Developmental Science. 2008. Vol.11. No.2. P.204-208. doi:10.1111/j.1467-7687.2007.00666.x
Nevins A., Pesetsky D., Rodrigues C. Pirahã exceptionality: A reassessment // Language. 2009a. Vol.85. No.2. P.355-404. doi:10.1353/lan.0.0107

Nevins A., Pesetsky D., Rodrigues C. Evidence and argumentation: A reply to Everett // Language. 2009b. Vol.85. No.3. P.671-681.

Pica P., Lemer C., Izard V., Dehaene S. Exact and approximate arithmetic in an Amazonian indigene group // Science. 2004. Vol.306. No.5695. P.499-503. doi:10.1126/ science. 1102085

RiveraS.M., Zawaydeh A.N. Word comprehension facilitates object individuation in 10-and 11-month-old infants // Brain Research. 2006. Vol.1146. P.146-157. doi:10.1016/j. brainres.2006.08.112

Ryle G. Ordinary language // The Philosophical Review. 1953. Vol.62. No.2. P. 167 - 186. doi:10.2307/2182792

Santos L.R., Sulkowski G.M., Spaepen G.V., Hauser M.D. Object individuation using property / kind information in rhesus macaques (Macaca mulatta) // Cognition. 2002. Vol.83. No.3. P.241 - 264. doi:10.1016/s0010-0277(02)00006-9

Varley R.A., $\quad$ Klessinger N.J.C., Romanowski C. A. J., Siegal M. Agrammatic but numerate // Proceedings of the National Academy of Sciences of USA. 2005. Vol.102. No.9. P.3519-3524.

Waxman S.R. All in good time: How do infants discover distinct types of words and map them to distinct kinds of meaning? // Infant pathways to language: Methods, models, and research directions / J. Colombo, P. McCardle, L. Freund (Eds.). Mahwah, NJ: Lawrence Erlbaum Associates, 2008. P.99- 118.

Waxman S.R., Braun I.E. Consistent (but not variable) names as invitations to form object categories: new evidence from 12-month-old infants // Cognition. 2005. Vol.95. No.3. P.59-68. doi:10.1016/j.cognition.2004.09.003

Werner H. Comparative psychology of mental development (with a new prologue by Margery B. Franklin). Clinton Corners, NY: Percheron Press, 2004.

Wierzbicka A. There are no "color universals" but there are universals of visual semantics // Anthropological Linguistics. 2005. Vol.47. No.2. P.217-244.

Wierzbicka $A$. Why there are no'colour universals' in language and thought // Journal of the Royal Anthropological Institute. 2008. Vol.14. No.2. P.407-425. doi:10.1111/j.1467-9655.2008.00509.x

Wilcox T. Object individuation: Infants' use of shape, size, pattern, and color // Cognition. 1999. Vol.72. No.2. P.125-166. doi:10.1016/s0010-0277(99)00035-9

$X u F$. The role of language in acquiring object kind concepts in infancy // Cognition. 2002. Vol.85. No.3. P.223-250. doi:10.1016/s0010-0277(02)00109-9

$X u F$. Sortal concepts, object individuation, and language // Trends in Cognitive Sciences. 2007. Vol.11. No.9. P.400-406. doi:10.1016/j.tics.2007.08.002

$X u$ F., Carey S. Infants' metaphysics: The case of numerical identity // Cognitive Psychology. 1996. Vol.30. P.111-153. doi:10.1006/cogp.1996.0005 


\title{
On the Influence of Culture on Language (in the Example of the Amazonian Pirahã Tribe)
}

\author{
Alexey D. Koshelev \\ LRC Publishing House, Moscow, Russia
}

\begin{abstract}
One of the central themes of the article is the nature of a culture's influence on its language. A society's civilizational progress contributes to the development of the content component of its language - the expansion of the range of its lexical and grammatical meanings. Everett's hypothesis about the influence of culture on its lan-guage system is discussed. Models of human development are proposed, formed by three components: Activity as the main component, with Thinking and Language as auxiliary components that ensure the successful per-formance of activities. In light of these models, some unusual properties of the language of the Pirahã tribe are analyzed, including its absence of color terms, counting words and passive voice. It is shown that these proper-ties are consequences of the initial stage of the tribe's progress, which would presumably be eliminated in case of its transition to subsequent stages of progress.
\end{abstract}

Correspondence: Alexey D. Koshelev, koshelev47@gmail.com, LRC Publishing House, Moscow, Russia

Keywords: Pirahã, activity, thinking, language development, culture, color terms, color naming, counter words, human model

Copyright $\odot$ 2018. Alexey D. Koshelev. This is an open-access article distributed under the terms of the Creative Commons Attribution License (CC BY), which permits unrestricted use, distribution, and reproduction in any medium, provided that the original author is credited and that the original publication in this journal is cited, in accordance with accepted academic practice.

Note. The article is partially based on an earlier afterword for the Russian translation of Daniel Everett's book: Koshelev, A. (2016). Pirakha kak primer yazyka, "zastyvshego" na nachalnoi stadii evolyutsii. Posleslovie [Piraha as a case of language that stopped on the initial stages of its devel-opment. An afterword] In D.L. Everett. Ne spi - krugom zmei! Byt i yazyk indeitsev amazonskikh dzhunglei [Don't sleep, there are snakes: Life and language in the Amazonian Jungle] (PS. Dronov, I.V. Mokin, E.N. Panov, Trans. into Russian), pp. 341-378. Moscow: LRC Publ.

Acknowledgements. The author is deeply indebted to Liudmila G. Zubkova and Ekaterina V. Pechenkova for fruitful discussion of the paper and for their valuable advice. I am grateful to anonymous reviewers for their helpful comments.

Received May 24, 2017, accepted March 26, 2018.

\section{References}

Andrick, G.R., \& Tager-Flusberg, H. (1986). The acquisition of colour terms. Journal of Child Language, 13(1), 119-137. doi:10.1017/s0305000900000337

Baudouin de Courtenay, I.A. (1963). Selected works on general linguistics., Vol.1. Moscow: Publishing House of the USSR Academy of Sciences. (In Russian).

Berlin, B., \& Kay, P. (1969). Basic color terms: Their universality and evolution. Berkeley: University of California Press. doi: $10.2307 / 2798490$

Blackwell, A.A. (2005). Acquiring the English adjective lexicon: Relationships with input properties and adjectival semantic typology. Journal of Child Language, 32(3), 535-562. doi:10.1017/s0305000905006938

Bornstein, M.H. (1985). Colour-name versus shape-name learning in young children. Journal of Child Language, 12(2), 387-393. doi:10.1017/s0305000900006498
Bower, T.G.R. (1974). Development in infancy. Oxford, England: WH Freeman.

Brannon, E.M. (2005). The independence of language and mathematical reasoning. Proceedings of the National Academy of Sciences of the USA, 102(9), 735-740. doi:10.1073/ pnas.0500328102

Burlak, S.A. (2018). Pirahã and spoken language. The Russian Journal of Cognitive Science, 5(1), 22-26. (In Russian).

Cejtlin, S.N. (1996). Usvoenie rebenkom prilagatelnykh [Acquisition of adjectives in children]. In Detskaya rech: norma $i$ patologiya [Child's speech: normative and pathologic] (pp.4-15). Samara: Samara State Universtity. (In Russian).

Cejtlin, S.N. (2009). Ocherki po slovoobrazovaniyu i formoobrazovaniyu $v$ detskoi rechi [Essays on word formation and morphogenesis in children]. Moscow: Znak. (In Russian).

Chuprikova, N.I. (2007). Umstvennoe razvitie: Printsip differentsiatsii [Psychology of mental development: The Principle of Differentiation]. Moscow: Piter. (In Russian). 
Chuprikova, N.I. (2015). Psikhika i psikhicheskie protsessy (sistema ponyatiy obshchey psikhologii) [Mind and mental processes (the system of concepts of general psychology)]. Moscow: LRC Publishers. (In Russian).

Dehaene, S. (2007). A few steps toward a science of mental life. Mind, Brain and Education, 1(1), 28-47. doi:10.1111/j.1751-228x.2007.00003.x

Dixon, R.M.W. (2004). Adjectives classes in typological perspective. In R.M.W. Dixon, \& A.Y. Aikhenvald (Eds.), Adjective classes: A cross-linguistic typology (pp.1-49). Oxford: Oxford University Press.

Dixon, R.M.W. (1982). Where have all the adjectives gone? And other essays in semantics and syntax. Berlin: Mouton. doi:10.1515/9783110822939

Ebeling, K.S., \& Gelman, S.A. (1990). Flexibility in semantic representations: Children's ability to switch among different interpretations of "big" and "little". In Papers and reports on child language development. Vol.29 (pp.38-46). Stanford, California: Department of Linguistics, Stanford University.

Everett, D. (2008). Don't sleep, there are snakes: Life and language in the Amazonian jungle. New York: Pantheon Books.

Everett, D. (2009). Pirahã culture and grammar: A response to some criticism. Language, 85(2), 405-442. doi:10.1353/ lan. 0.0104

Everett, D.L. (2005). Cultural constraints on grammar and cognition in Pirahã: Another look at the design features of human language. Current Anthropology, 46(4), 621-646. doi:10.1086/431525

Ferry, A., Hespos, S., \& Waxman, S. (2010). Categorization in 3- and 4-month-old infants: An advantage of words over tones. Child Development, 81(2), 472-479. doi:10.1111/j.1467-8624.2009.01408.x

Fulkerson, A.L., \& Waxman, S.R. (2007). Words (but not Tones) facilitate object categorization: Evidence from 6- and 12-month-olds. Cognition, 105(1), 218-228. doi:10.1016/j. cognition.2006.09.005

Futrell, R., Stearns, L., Everett, D.L., Piantadosi, S.T., \& Gibson, E. (2016). A corpus investigation of syntactic embedding in Pirahã. PLoS One, 11(3), e0145289. doi:10.1371/journal. pone. 0145289

Gasser, M., \& Smith, L. (1998). Learning nouns and adjectives: a connectionist account. Language and Cognitive Processes, 13(2/3), 269-306. doi:10.1080/016909698386537

Gentner, D. (2003). Why we're so smart. In D. Gentner, \& S. Goldin-Meadow (Eds.), Language in mind: Advances in the study of language and thought (pp.195-235). Cambridge, MA: MIT Press.

Goldstein, K., \& Scheerer, M. (1941). Abstract and concrete behavior an experimental study with special tests. Psychological Monographs, 53(2), i - 151. doi:10.1037/h0093487

Goodale, M.A., $\quad$ Milner, A.D., Jakobson, L.S., \& Carey, D.P. (1991). A neurological dissociation between perceiving objects and grasping them. Nature, 349(6305), 154-156. doi: $10.1038 / 349154 \mathrm{a} 0$

Hauser, M.D. (2000). Wild minds: What animal really think. N. Y.: Henry Holt.

Ivanov, V.V. (2008). Ob evolyutsii pererabotki i peredachi informatsii v soobshchestvakh lyudei i zhivotnykh [On evolution of information processing and information transfer in human and animal social groups]. Voprosy Jazykoznanija (Topics in the Study of Language), (4), 3-14. (In Russian).

Kay, P. (2015). Universality of color categorization. In A.J. Elliot, M.D. Fairchild, \& A. Franklin (Eds.), Handbook of color psychology (pp.245-258). Cambridge: Cambridge University Press.

Kibrik, A.A. (2018). Tyranny of another mind. The Russian Journal of Cognitive Science, 5(1), 27-36. (In Russian).

Koshelev, A.D. (2011). V poiskakh universalnoi skhemy razvitiya [In search for the universal scheme of development]. In N.I. Chuprikova, \& A.D. Koshelev (Eds.), Integratsionnodifferentsionnaya teoriya razvitiya [Integrational-differential theory of development] (pp.217-234). Moscow: LRC Publishers. (In Russian). Retrieved from https://independent. academia.edu/AlexeyKoshelev
Koshelev, A. D. (2016). [On structural and genetic similarities of lexical and grammatical meanings (A cognitive analysis of verb transitivity and voice)]. The Bulletin of the Russian Academy of Sciences: Studies in Literature and Language, 75(3), 19-39. (In Russian). Retrieved from http://izv-oifn. ru/articles/206/public/206-529-1-PB.pdf

Koshelev, A.D. (2017). Ocherki evolyutsionno-sinteticheskoi teorii yazyka [Essays in the evolutionary sinthetic theory of language]. Moscow: LRC Publishers. (In Russian). Retrieved from $\mathrm{https://independent.academia.edu/AlexeyKoshelev.}$

Lakoff, G. (2008). Women, fire, and dangerous things. Chicago: University of Chicago press.

Landau, B., Smith, L. B., \& Jones, S.S. (1988). The importance of shape in early lexical learning. Cognitive Development, 3(3), 299-321. doi:10.1016/0885-2014(88)90014-7

Leslie, A.M. (1982). The perception of causality in infants. Perception, 11(2), 173-186. doi:10.1068/p110173

Leslie, A.M. (1984). Spatiotemporal continuity and the perception of causality in infants. Perception, 13(3), 287-305. doi:10.1068/p130287

Markson, L., Diesendruck, G., \& Bloom, P. (2008). The shape of thought. Developmental Science, 11(2), 204-208. doi:10.1111/j.1467-7687.2007.00666.x

Marr, N.Y. (1933). Izbrannye raboty [Selected works]. Vol. I. Leningrad: AN SSSR. (In Russian).

Marr, N.Y. (1936). Izbrannye raboty [Selected works]. Vol. II. Leningrad: AN SSSR. (In Russian).

Morgan, L.H. (1877). Ancient society; or, researches in the lines of human progress from savagery, through barbarism to civilization. N.Y.: H. Holt.

Nevins, A., Pesetsky, D., \& Rodrigues, C. (2009). Pirahã exceptionality: A reassessment. Language, 85(2), 355-404. doi:10.1353/ lan.0.0107

Nevins, A., Pesetsky, D., \& Rodrigues, C. (2009). Evidence and argumentation: A reply to Everett. Language, 85(3), 671-681.

Nikulin, A.V. (2018). The immediacy of experience principle: A critical assessment. The Russian Journal of Cognitive Science, 5(1), 81-95. (In Russian).

Paul, H. (1890). Principles of the history of language. London, New York: Longmans, Green, and Co.

Pica, P., Lemer, C., Izard, V., \& Dehaene, S. (2004). Exact and approximate arithmetic in an Amazonian indigene group. Science, 306(5695), 499-503. doi:10.1126/science.1102085

Pinker, S. (2003). The language instinct: How the mind creates language. London: Penguin.

Pinker, S. (2007). The stuff of thought: Language as a window into human nature. London: Penguin.

Rivera, S.M., \& Zawaydeh, A.N. (2006). Word comprehension facilitates object individuation in 10-and 11-monthold infants. Brain Research, 1146, 146-157. doi:10.1016/i. brainres.2006.08.112

Rozengardt-Pupko, G.L. (1948). [Speech and the development of perception in early childhood]. Moscow: Uchpedgiz. (In Russian).

Rozengardt-Pupko, G.L. (1963). Formirovanie rechi u detei rannego vozrasta [Speech development in early childhood]. Moscow: Uchpedgiz. (In Russian).

Ryle, G. (1953). Ordinary language. The Philosophical Review, 62(2), 167-186. doi:10.2307/2182792

Santos, L.R., Sulkowski, G.M., Spaepen, G.V., \& Hauser, M.D (2002). Object individuation using property / kind information in rhesus macaques (Macaca mulatta). Cognition, 83(3), 241-264. doi:10.1016/s0010-0277(02)00006-9

Sapir, E. (1993). Selected works on linguistics and culturology. Moscow: Progress. (In Russian).

Sechenov, I.M.Koshtoyants, K.S. (Ed.). (1952). Izbrannye proizvedeniya. T. 1: Fiziologiya i psikhologiya [Selected works. Vol.1. Physiology and psychology]. Moscow: AN SSSR. (In Russian)

Solovyev, V.S. (1988). Collected works. Moscow: Mysl. (In Russian) Spencer, H. (1875). The principles of biology (Vol.2). N.Y.: Appleton.

Varley, R.A., Klessinger, N.J.C., Romanowski, C.A.J., \& Siegal, M. (2005). Agrammatic but numerate. Proceedings of the National Academy of Sciences of USA, 102(9), 3519-3524. 
Vendler, Z. (1963). The grammar of goodness. The Philosophical Review, 72(4), 446-465. doi:10.2307/2183030

Voeikova, M.D. (2011). Rannie etapy usvoeniya det'mi imennoi morfologii russkogo yazyka [Early stages of Russian nominal morphology acquisition in child language]. Moscow: Znak. (In Russian).

Vygotsky, L.S. (2004). Psihologia razvitia rebionka [Psychology of child development]. Moscow: Smysl, Eksmo. (In Russian).

Waxman, S.R. (2008). All in good time: How do infants discover distinct types of words and map them to distinct kinds of meaning? In J. Colombo, P. McCardle, \& L. Freund (Eds.), Infant pathways to language: Methods, models, and research directions (pp.99-118). Mahwah, NJ: Lawrence Erlbaum Associates.

Waxman, S.R., \& Braun, I.E. (2005). Consistent (but not variable) names as invitations to form object categories: new evidence from 12-month-old infants. Cognition, 95(3), 59-68. doi:10.1016/j.cognition.2004.09.003

Werner, H. (2004). Comparative psychology of mental development (with a new prologue by Margery B. Franklin). Clinton Corners, NY: Percheron Press.
Wierzbicka, A. (2005). There are no "color universals" but there are universals of visual semantics. Anthropological Linguistics, 47(2), 217-244.

Wierzbicka, A. (2008). Why there are no 'colour universals' in language and thought. Journal of the Royal Anthropological Institute, 14(2), 407-425. doi:10.1111/j.1467-9655.2008.00509.x

Wilcox, T. (1999). Object individuation: Infants' use of shape, size, pattern, and color. Cognition, 72(2), 125-166. doi:10.1016/ s0010-0277(99)00035-9

$\mathrm{Xu}, \mathrm{F}$. (2002). The role of language in acquiring object kind concepts in infancy. Cognition, 85(3), 223-250. doi:10.1016/ s0010-0277(02)00109-9

$\mathrm{Xu}, \mathrm{F}$. (2007). Sortal concepts, object individuation, and language. Trends in Cognitive Sciences, 11(9), 400-406. doi:10.1016/j. tics.2007.08.002

Xu, F., \& Carey, S. (1996). Infants' metaphysics: The case of numerical identity. Cognitive Psychology, 30, 111-153. doi:10.1006/ cogp.1996.0005 


\title{
Язык и культура - две стороны одной медали
}

\section{Евгений Николаевич Панов}

Институт проблем экологии и эволюции им. А.Н. Северцова РАН, Москва, Россия

\begin{abstract}
Аннотация. В статье приводится критика взглядов Д. Эверетта, изложенных в его книге «Не спи - кругом змеи» в форме комментариев к путевым заметкам. Описание культуры этноса пираха выглядит поверхностным и не вполне адекватным. Это касается в первую очередь поразительной наивности автора в трактовках категории «термины родства», основополагающей для любого исследования по социальной антропологии. Отрицая существование у пираха мифологии, Эверетт отрезает себе путь к попыткам глубокого анализа структуры коллективного сознания социума. Таким образом, понятие «культура» обедняется, в ее ведении остается преимущественно сфера материальной культуры. «Принцип непосредственного восприятия», предлагаемый автором книги, сугубо умозрителен и едва ли подлежит строгой эмпирической проверке. Приведены примеры адекватного подхода к анализу архаических культур со ссылками на классические исследования по этнографии ряда этносов: карам и дани (Новая Гвинея), бушменов и нуэров (Африка) и некоторых других.
\end{abstract}

Контактная информация: Евгений Николаевич Панов, panoven@mail.ru; 119071, Москва, Ленинский проспект, д. 33.

Ключевые слова: концепция лингвистической относительности, гендерный символизм, категоризация метафорическая, лексические категории числа, времени и цвета

(c) 2018 Евгений Николаевич Панов. Данная статья доступна по лицензии Creative Commons "Attribution" («Атрибуция») 4.0. всемирная, согласно которой возможно неограниченное распространение и воспроизведение этой статьи на любых носителях при условии указания автора и ссылки на исходную публикацию статьи в данном журнале в соответствии с канонами научного цитирования.

Статья поступила в редакцию 29 мая 2017 г. Принята в печать 28 марта 2018 г.

\begin{abstract}
... Человеческое общество, вся культура и вся иивилизация в конечном счете есть не что иное, как мир понятий, застывших в определенной форме и определенных видах...
\end{abstract}

\section{Питирим Сорокин}

Судьба книги Дэниела Эверетта (2008/2016) и шумный эффект, произведенный ею, вызывают в памяти еще один эпизод из истории научно-популярной литературы о поведении человека. В 1968 году похожую сенсацию произвела другая книга, под названием «Свирепые люди», за авторством американского этнографа Наполеона Шегнона (Chagnon, 1968). В ней речь шла о южноамериканском этносе яномамо. Книга выдержала четыре переиздания и стала самой читаемой в широкой аудитории публикацией по социальной антропологии.

Сами антропологи упрекали автора в отходе от принципов культурного релятивизма. Он и в самом деле нарисовал образ аборигенов как людей, в среде которых убийство ближнего не только не осуждается, но считается деянием скорее почетным. Но Шегнону не пришло в голову отказать яномамо в способности рас- суждать и говорить о чем-то, что так или иначе выходит за рамки сиюминутной ситуации. Это сделал, рубя сплеча, Эверетт в отношении пираха (например, Эверетт, 2016, с. 143). Как правильно заметил один из выступавших на круглом столе в Институте языкознания РАН, посвященном выходу перевода книги Дэниела Эверетта, это значит лишить их язык одной из главных его функций.

Не будучи лингвистом, я не могу судить, насколько верно автор книги описал фонетику и морфологию языка пирахан. Но нарисованная им картина того, что он называет «культурой» этого народа, представляется мне весьма поверхностной и не вполне адекватной. В методологии науки считается, что хорошее описание объекта - это уже значительная часть объяснения. С моей точки зрения, описание коллективного сознания, лежащего в основе любой культуры, никак нельзя считать удовлетворительным в исполнении Эверетта. Отсюда и дальнейшие проблемы с его попытками изменить направление пресловутой «стрелки» - не от языка к культуре, как предлагал Б. Уорф, а на противоположное.

М.А. Кронгауз в своем выступлении на круглом столе сравнил Эверетта с Уорфом (см. также статью М. А. Кронгауза «Дэниел Эверетт и Бенджамин Уорф: 
лингвистические и нелингвистические параллели» в настоящем выпуске). Мне кажется, что сравнение не в пользу второго исследователя. Тот, несомненно, был крупным мыслителем, чего едва ли можно сказать об Эверетте. Уорф вряд ли позволил бы себе такое высказывание: «Наука во многом представляет собой обнаружение и открытие понятий, для которых раньше не было слов» (Эверетт, 2016, с. 2381). Вероятно, он хотел сказать: «Наука во многом представляет собой обнаружение и открытие сущностей, для которых раньше не было понятий». Разумеется, сказанное можно было бы списать на неточность, и даже неряшливость, автора в поисках им языковых средств для донесения своих мыслей до читателя. Это характерная особенность литературного стиля Эверетта, с чем я столкнулся при переводе одной из глав его книги на русский язык². Но все же такого рода декларации представляются мне недопустимыми в устах популяризатора науки.

\section{Лакуны в описании культуры пираха}

На с. 243 книги Д. Эверетта сказано: «Теории влияют на наше восприятие. Они часть той культурной информации, которая ограничивает наше мировоззрение». Против этой, прописной, по сути дела, истины, разумеется, возразить нечего. Но пример, который Эверетт приводит в ее подтверждение, может вызвать только улыбку. «Так, например, - пишет он, - один раз я принял анаконду за лежащее на воде бревно: знание [моей?] культуры подсказывало мне, что, путешествуя на лодке, нужно опасаться бревен. Но культура не давала мне никаких сведений о том, как выглядит крупная анаконда, пльвущзая навстречу» (курсив мой - Е.П). Спрашивается, идет ли здесь речь о «культуре» или о неспособности новичка отличить неодушевленный предмет от живого существа в силу, например, его близорукости или отсутствия элементарных знаний о местной природе?

Примерно так же Эверетт представляет себе, что именно вкладывается в культурологии в понятие «термины родства». Система родства, описываемая этими терминами, представляет собой скрытый от поверхностного взгляда базис социальной структуры любого архаического общества, без единого известного исключения. Вот, например, что говорится об этом в описании жизненного уклада перуанских индейцев шаранахуа ${ }^{3}$ :

«Во внутренней структуре этого общества отношения взаимности (reciprocity), ответственности и прерогатив персоны базируются на тех ролях, которые индивиды выполняют в сетях системы родства, и на оппозиции таких ролей у мужчин

\footnotetext{
1 Сначала я усомнился в том,в том, что фраза переведена верно, и обратился для проверки к оригиналу текста. Оказалось, что именно такова она, слово в слово, на английском языке: «In fact, this strong Whorfian account is incompatible with science, because science is largely about discovering concepts for which we previously had no words» (Everett, 2008, p. 320).

2 Глава 11. Фонетика пираха и ее влияние на каналы дискурса.

3 Описание выполнено антропологом Дж. Сискинд в книге «To hunt in the morning» (1973). Далее приводится цитата из рецензии на эту книгу (Прим. ред.).
}

и женщин. Человек прослеживает свое родство с предками по одной или двум патрилинейным генеалогиям, с учетом таких событий в прошлом, как кросскузенные браки, эпизоды полигинии, а также опираясь на сведения о местах рождения предков по материнской линии. Объясняя свою систему родства, аборигены приводят примеры того, какие обязанности она налагает на индивида в сиюминутных конкретных ситуациях и какое решение он может принять относительно своих действий, оставаясь при этом в рамках того спектра возможностей, который разрешен существующими правилами» (Newton, 1974, p. 592).

А вот что мы читаем на с. 144 книги Эверетта:

«Термины родства охватывают срок жизни одного человека и поэтому в принципе подкрепляемы личным опытом: средняя продолжительность жизни индейца пираха - сорок пять лет; за это время еще можно стать дедом (и увидеть, как внуки пойдут у других), но не прадедом. Иногда кто-то действительно доживает до правнуков, но стать очевидцами подобного события удается не всем. Поэтому система обозначений родства не предусматривает слова „прадед“, чтобы лучше отразить личный опыт среднестатистического члена племени».

Речь здесь идет только о вертикальных родственных связях, и ни слова не сказано о горизонтальных (такие термины, как, например, «зять», «сноха», «шурин», «невестка» и многие другие), которые, собственно говоря, и делают общество системой, воспринимаемой в сознании людей в качестве некой структурно упорядоченной сети межличностных отношений. Поразительная наивность трактовки одного из основополагающих понятий социальной антропологии должна была потребовать от переводчика соответствующих комментариев в сноске, чего, к сожалению, им сделано не было. В противном случае лингвисты, горячо обсуждающие достоинства и недостатки книги Эверетта, могли бы задуматься о качестве описания в ней «культуры» пираха.

Очень трудно поверить и в утверждение Эверетта об отсутствии у пираха мифологии. Коль скоро у них, как и во всех без исключения архаических обществах, существует вера в духов (Эверетт, 2016), такой пробел в содержании коллективного сознания весьма маловероятен. Дело в том, что сам мир духов обычно уподобляется в своем устройстве человеческому обществу. В этом воображаемом параллельном мире действуют свои закономерности отношений. Например, между духами вредоносными в разной степени и теми, которые работают на благо людям, к тому же по-разному в соответствии с разными сферами их компетенции (влияние на погоду, урожай и так далее). Автор пишет, что духи в понимании аборигенов являются частью природы и «действуют согласно природе» (с. 292). Как именно - это и есть мифология. Но либо Эверетту не удалось выяснить деталей, либо он счел эту декларацию достаточной для объяснения сути верований народа. 
Понятно, что добыть такую информацию совсем не легко. Вот что пишет об этом этнограф, добившийся все-таки успеха в своем начинании:

«Мифология дани ${ }^{4}$ не слишком дифференцирована и не играет особенно важной роли в жизни этих людей. Основа ее состоит из описаний событий, связанных с первым человеком по имени Накматуги и с возникновением разных вещей. Очевидно, что миф в целом не пользуется широкой известностью у аборигенов, но считается в высшей степени сакральным. В него посвящают лишь мужчин, достигших совершеннолетия. Только после бесчисленных попыток... мне удалось получить изложение мифа - от единственного информанта Um'ue, пользующегося авторитетом в своей общине. Ни разу не удалось выслушать полную версию мифа. Необходимо было задавать наводящие вопросы по окончании каждого из десяти эпизодов» (Heider, 1970/2006, p. 140; курсив мой - Е.П.).

Далее этот автор приводит их полный перечень: земля и небо (кстати, сюжет, обсуждаемый у пираха! (Эверетт, 2016, с. 141)); происхождение каннибализма; следы Накматуги; отделение человека от животных; происхождение соли; первый человек-предок; происхождение гор; суть ритуалов, адресованных духам; происхождение свиней; происхождение собак.

Цитируя В. Б. Касевича:

«Есть к текстам Эверетта общее методическое замечание. Когда занимаешься полевыми исследованиями, работаешь с новым, неизвестным материалом, весьма желательно учитывать, как минимум, два обстоятельства. Во-первых, необходимо освоить „технологию“ полевых исследований (см., напр., Kibrik, 1977), включая методику разработки анкет для испытуемых и т.п.; во-вторых, полезна постоянная оглядка на возможные типологические параллели: они не обладают доказательной силой для решения соответствующих задач, но помогают более осмысленно подойти к проблеме, избежать „теоретического шока“ (наподобие „открытия“ фонологических тонов в пираха)» (Касевич, 2018, с. 78).

А что делает Эверетт: он обращается с расспросами к миссионерам, к своей жене, а затем обкладывается «книгами по полевым исследованиям в лингвистической антропологии» и начинает «работать, тщательно соблюдая описанные в них приемы» (Эверетт, 2016, с. 145).

\section{Возможные причины просчетов Эверетта}

Я предполагаю, что концепция, предлагаемая им, формировалась следующим образом. Как только он убедился в простоте языка пираха, что не могло не броситься в глаза, следовало понять в первом прибли-

4 Обитатели высокогорий Новой Гвинеи с материальной культурой на уровне неолита. жении, какими факторами этот феномен может быть обусловлен. Коль скоро материальная культура этих аборигенов также довольно примитивна (по крайней мере, на первый взгляд), созрело предположение, согласно которому в данном случае свойства языка детерминированы особенностями культуры. Возник образ людей, психика которых также едва ли может обладать особой глубиной.

В подобных случаях у людей, не слишком склонных к «здоровой рефлексии ученого», по выражению философа и методолога науки Н.Е. Никитина (1970), наскоро выстроенная гипотеза становится навязчивой идеей и требует не долгой мучительной проверки, а поиска фактов или мысленных конструкций, ее подтверждающих. Эта широко распространенная стратегия верификации гипотезы является истинным бичом науки, существенно тормозящим ее развитие и способствующим накоплению в ней ошибочных теорий (стадия так называемой нормальной науки, по Т. Куну (1977)).

Адекватный подход к анализу сложнейших психосоциальных процессов этнограф К. Хейдер назвал холистическим. Суть его в том, что «...он оставляет [на время - Е.П.] открытыми вопросы, связанные функциональными и причинными объяснениями происходящего. Но, что особенно важно, избегает тенденции заранее высказать функциональные гипотезы, которые сузили бы поиски таких объяснений, выдвинув на передний план немногие из всего обилия факторов, которые могли бы иметь значение в принципе» (Heider, 1970/2006, с. 125).

Мне кажется, что Эверетт не принял во внимание реальность такой угрозы. Вместо того, чтобы «копать глубже», он остановился на схематичной картине, говорящей, якобы, о некой уникальности психического облика пираха, и изобрел в подтверждение этого шаблона свой «принцип непосредственного восприятия». Он оказался очень удобным аргументом для объяснения чего угодно, неуязвимым к тому же для эмпирической проверки. Как пишет сам автор, и бедность терминов родства, и отсутствие мифологии «приобретают смысл в свете теории о непосредственном восприятии» (Эверетт, с. 145).

На этом я заканчиваю обсуждение книги Эверетта, которую, по верному замечанию одного из выступавших на круглом столе, трудно рассматривать не только как строго научную, но даже как научно-популярную, поскольку она, скорее всего, принадлежит жанру записок путешественника. Перейду теперь к гораздо более интересной теме соотношения языка и культуры.

Существует несметное количество превосходных исследований, проделанных этнографами и культурологами, которые предоставляют богатейший материал для размышлений на эту тему. Даже если оставить в стороне давно ставшие классическими работы Б. Малиновского (2004), В. Тернера (1983) и Э. ЭвансПричарда (1985), перечень более поздних книг ничуть не худшего стандарта, наполненных обилием фактов и их глубоким осмыслением, мог бы включить в себя как минимум с десяток названий. Все они написаны хорошим литературным языком и, на мой взгляд, гораздо более заслуживают перевода на русский язык, чем книга Эверетта. Однако по воле судеб именно 
его поспешная идея о неком «приоритете» культуры над языком произвела столь сильное впечатление на лингвистов.

\section{Язык и мировоззренческий каркас культуры}

Вообще говоря, я не уверен в том, что вопрос о том, какая из этих двух сущностей первична, а какая вторична в их эволюционном развитии, не является предметом софистики. Они настолько тесно взаимосвязаны, что сторонники той или иной позиции легко могут оказаться в положении остроконечников и тупоконечников из «Путешествия Гулливера». Воспользуюсь здесь метафорой, которую употребил в другом месте в несколько ином контексте $e^{5}$ «Язык неотделим от культуры в такой же степени, в какой кожица, одевающая плод, неотделима от его мякоти или глазурь - от самого керамического изделия» (Панов, 2012, с. 326).

Вместе с тем я все же склоняюсь к мысли, что культура, отражающая в себе структуру общих представлений ее носителей о внешнем мире и о себе самих, имеет в своей основе имманентное стремление людей к реализации их языковых способностей. Мне кажется, что хорошей иллюстрацией этой мысли могут служить рассуждения Малиновского о природе магии. Вот что он пишет о своем исследовании магических заклинаний у аборигенов Тробрианских островов (западная Меланезия).

«[B] качестве преобладающих в обществе моральных идей и правил, хотя и не кодифицированных, магическая теория может быть установлена путем анализа общественного поведения. Изучая обряды, мы видим некоторые определенные принципы верований и догматов. Точно так же, анализируя непосредственное словесное выражение определенных способов мышления в магических формулах, мы можем справедливо предположить, что эти способы мышления должны так или иначе руководить теми, кто их создал... Значительная часть слов, встречающихся в магических текстах, не принадлежит к обыденной речи, но является архаизмами, мифическими именами и странными сочетаниями, образованными в соответствии с необычными лингвистическими правилами. Поэтому сначала мне следовало прояснить устаревшие выражения и мифические упоминания, а также найти современные эквиваленты всех архаических слов...

Магия не строится в повествовательном стиле. Она не служит для передачи идей от одного человека к другому. Она не подразумевает и последовательного, логичного смысла. Это - инструмент, служащий особым целям, предназначенный для осуществления особенной власти человека над вещами, а ее значение, придающее этому слову более широкий смысл, может

\footnotetext{
5 В книге «Парадокс непрерывности: Языковой рубикон» (с. 326), где речь шла о соотношении коммуникации и социальной организации у человекообразных обезьян.
}

быть понято только в связи с этой целью. Следовательно, речь идет не о значении логически или тематически связанных идей, но о значении выражений, встраиваемых друг в друга и в общее целое, соответственно чему его можно назвать магическим порядком мышления, или, пожалуй, более правильно, - магическим порядком направления слов к их цели» (Малиновский, 2004, с. 425-429; курсив мой - Е.П.).

Приведу более наглядный пример того, как мифологический нарратив устанавливает предписания и запреты, регулирующие повседневную практическую деятельность в данной культурной общности. Новозеландский антрополог Р. Балмер, изучавший лексику народности карам в высокогорьях Новой Гвинеи, обнаружил у этих аборигенов целую систему обычаев, связанных с их отношением к объектам охотничьего промысла. Особое место в этом своде правил занимает птица казуар весьма необычной внешности ${ }^{6}$. Казуар не вполне похож на птицу, и аборигены не считают его таковой, так что в их классификации живых существ для него отведена отдельная категория.

У карам существует целый ряд запретов, касающихся обращения с казуарами. Например, убив его, охотник может готовить трапезу, только не уходя далеко от края леса. Там он должен съесть сердце своей жертвы. Ему категорически запрещено приносить добычу в деревню. Сделав это, он ставит под угрозу урожай таро и бананов. Охотник оказывается во власти враждебных мистических сил и не имеет права на протяжении месяца приближаться к плантациям таро и тем более самому принимать участие в его выращивании. Живых казуаров нельзя доставлять в деревню и, разумеется, одомашнивать их. Еще одно любопытное правило состоит в том, что добыть казуара на охоте можно, поймав в ловушку или убив тупым оружием, но никак - стрелой или копьем. Иначе будет пролита кровь жертвы, а этого не должно случиться ни под каким видом.

Как же сами аборигены объясняют все эти обычаи? Они говорят: «Когда мы бродим по лесу и слышим крик казуара, мы говорим: где-то здесь наши сестры и двоюродные сестры» (Bulmer, 1967, p. 18). В основе этих представлений лежит следующий миф:

\footnotetext{
«Однажды мужчина поставил в лесу силки на дичь, замаскировал их листьями, и в них попалась его сестра. Брат не сразу пошел проверить ловушку, а когда вернулся, увидел, что сестра превратилась в самку казуара, которая успела уже снести несколько яиц. Брат выстрогал из бамбука свистульку и повесил ее на дерево, так что ветерок мог производить звуки, а сестра, слыша их, должна была оставаться неподалеку.

6 Казуары - крупные нелетающие птицы (вторые по величине птицы после африканского страуса), принадлежащие фаунам Новой Гвинеи и крайнего северо-востока Австралии. Их перья внешне более похожи на шерсть млекопитающих. Все три вида имеют вырост на голове, который называется «шлемом». Он состоит из рогового вещества губчатой структуры. Голова и шея ярко-голубого цвета, с груди свисает кожистая алая «сережка». Взрослые особи шлемоносного казуара достигают в высоту 1.5-1.8 метров (иногда до двух метров) и веса около 60 кг.
} 
Позже две сестры из другой деревни пришли в лес собирать съедобные листья для готовки и услышали свист. Они были озадачены, и одна из них влезла на дерево, нашла свистульку и сломала ее. Казуариха пошла за сестрами в деревню, где мужчины схватили луки и стрелы, многократно ранили пришелицу, а затем убили и съели. Брат убитой в целях мести завлек двух сестер-виновниц в лес, а когда их родичи пришли за ними, подрубил большое дерево так, что оно упало на них, и все они умерли» (Bulmer, 1967, p. 17-18).

Возвращаясь к цитате из Малиновского, последуем его совету и не будем искать в этом нарративе некой строгой логики. Здесь много недомолвок, что не мешает полному доверию туземцев к тому, что однажды было сказано в далеком прошлом. Аборигену очевидно лишь одно: казуара не позволено убивать холодным оружием: ведь он - родич карам, а кровь родичей не должна окропить землю. Запрет проистекает из правила, регулирующего конфликты между самими людьми: родича можно ударить в драке только тупой стороной мотыги.

В любом случае карам ставят почти что знак равенства между убийством казуара и человека. Убивший казуара должен съесть его сердце. Убивший человека не делает этого, но обязан в самое ближайшее время, когда режут свинью, съесть ее сердце «взамен». Понятие «сердце» равносильно таким, как «душа» и «жизненная сила», которые продолжают существовать после смерти в качестве призраков или привидений. Поэтому, съедая сердце свиньи, убийца предотвращает его преследование своей жертвой в потустороннем мире. А съесть сердце казуара следует для того, чтобы его душа вернулась назад в лес и не препятствовала там охоте людей на казуаров в будущем (Bulmer, 1967).

\section{Материальная культура и язык}

Я предполагаю, что идею Эверетта о том, что культура формует язык, а не наоборот, можно считать иллюзорной по следующей причине. У меня создалось впечатление, что он склонен приравнивать культуру вообще к культуре материальной. Об этом свидетельствует, на мой взгляд, игнорирование им того, что я называю $\mathcal{M u - ~}$ ровоззренческим каркасом культурь. Что дело обстоит именно так, я попытался показать выше в разделе «Лакуны в описании культуры пираха».

Разумеется, не может быть ни малейшего сомнения в том, что поступательное развитие и усложнение материальной культуры неизбежно влечет за собой экспоненциальное расширение словарного состава языка. Заключение настолько самоочевидно, что какие-либо дополнительные аргументы представляются излишними. И все же хочется привести один особенно яркий пример этой закономерности.

Речь пойдет о скотоводческом этносе нуэры, обитающем в Восточной Африке. Как пишет Эванс-Причард, знаток их образа жизни, «каждому, кто хочет понять поведение нуэров, можно посоветовать: „Ищите корову“» (Эванс-Причард, 1985, с. 26). Этой теме в его книге посвящена целая обширная глава (ЭвансПричард, 1985, с.26-52), а все сказанное в ней может служить прекрасной иллюстрацией принципа СепираУорфа. В языке нуэров имеется несколько тысяч слов для описания комбинаций окраски шерсти и рисунка в масти коров и быков в сочетании с разными вариантами формы их рогов и с многочисленными терминами, указывающими на пол и возраст животного. Эванс-Причард подчеркивает, что все это лексическое богатство не ограничивается потребностью говорить с особой точностью о животных в контексте практического скотоводства и в определенных социальных ситуациях. Поскольку тема скота широко представлена в фольклоре, в том числе и песенном, столь дифференцированная терминология служит также обозначению определенных категорий в структуре ритуалов и обогащает язык народа поэтическим началом (там же, с. 45).

Постоянная сосредоточенность этих людей на благополучии их стада преломляется неожиданным образом даже в присвоении ими имен друг другу. Мужчин часто называют именем, которое отражает масть и другие особенности их любимых быков, а женщины берут имена коров, которых они доят. Даже маленькие мальчики, играя на пастбище, называют друг друга прозвищами своих быков. Ребенок часто принимает имя бычка от той коровы, которую доит его мать и он сам. Иногда за человеком навсегда остается имя его быка, а не то, которое было дано ему при рождении.

\section{Метафорическая составляющая языка}

Такие особенности языка пирахан, как, скажем, минимизация числа счетных слов ${ }^{7}$ или же понятий, связанных с делением хода времени на четко разграниченные отрезки (день, ночь и другие), Эверетт объясняет просто: если таких категорий нет, значит они не существенны для людей в их повседневной практической деятельности. В этом объяснении, кажущемся на первый взгляд вполне правдоподобным, не учитывается то важное обстоятельство, что далеко не все в языке непременно должно отображать утилитарные сиюминутные потребности их носителей.

К числу важных составляющих языка, которые трудно объяснить с позиций такой упрощенной трактовки, относится, в частности, так называемый гендерный символизм. Здесь перед нами фрагмент категоризации явлений внешней реальности по аналогии с тем, что лежит в самом фундаменте социальной структуры общества, где одна из наиболее принципиальных сторон всей этой системы есть реализация оппозиции «мужское-женское».

Гендерный символизм оказывается универсальным способом метафорической категоризации, поскольку имеет место во всех достаточно хорошо изученных архаических культурах. В сфере языка он почти несомненно предшествовал становлению грамматической категории рода (см. ниже). По словам одного из авторов, именно метафора, рисующая отношения меж-

7 Как мы увидим ниже, утверждение Эверетта об их полном отсутствии сомнительно. 
ду объектами какой-либо одной категории в терминах другой, оказывается критической как в функционировании языка, так и в отображении «реальности» в сознании данного социального коллектива (Moore, 1986, p. 75-77). Сюда, вне всякого сомнения, относится и явление полового символизма (обзор сведений по этой теме см. в работе: Панов, 2017, с. 285-288).

У бушменов, например, поле ассоциаций, определяемое им, чрезвычайно обширно и покрывает буквально все сферы повседневного опыта. Вот их перечень (таблица 1), который, вероятно, нельзя считать исчерпывающим (Solomon, 1992). У этого народа функции категоризации реальности, осуществляемой на основе гендерной оппозиции, выходят далеко за пределы всего того, что связано с сексом и воспроизводством потомства. Они оказываются определяющими также в таких сферах, как, скажем, состояние погоды и доступность жизненно важных ресурсов.

Таблица 1. Ассоциации в рамках полового символизма у бушменов (по Solomon, 1992, р. 299).

\begin{tabular}{ll}
\hline женское начало & мужское начало \\
\hline круглый & тонкий \\
\hline толстый & стройный \\
\hline низкий & высокий \\
\hline широкий & узий \\
\hline тупой & острый \\
\hline низ & верх \\
\hline левый & правый \\
\hline много & мало \\
\hline да & после \\
\hline слабый & сильный \\
\hline травоядный & хищный \\
\hline жертва & охотник \\
\hline кровь & вода / дождь \\
\hline смерть & жизнь \\
\hline сборище & охота \\
\hline прерывистость & непрерывность \\
\hline полная луна & месяц \\
\hline
\end{tabular}

В этом плане любопытна одна из них, проистекающая из понимания круглого и низкого как женских характеристик, с одной стороны, и стройного и высокого как мужских качеств - с другой. У одного из бушменских племен, в языке которого существуют классификаторы грамматического рода, они добавляются к названиям растений, общее слово для которых $h i$. Тогда $h i+b a$ (высокий, стройный) означает ДЕРЕВО, a $h i+s a$ (низкий, круглый) - КУСТ.

При ознакомлении с таблицей смысловых противопоставлений в сознании бушменов естественным образом возникает вопрос, почему в «женской колонке» стоит предлог «до», а в мужской — «после». Дело в том, что в мифологии бушменов (языковая группа нхаpo) говорится о двух актах творения людей. Женщина была создана только однажды и сохранила в себе черты примитивного животного начала, мужчина же достиг полного человеческого совершенства после второго творения. Животная природа отождествляется с сексу- альностью, и женщины были первыми, кто познал ее привлекательность. Мужчины, напротив, не интересовались этим до тех пор, пока не увидели своих потенциальных супруг, сидящих в верхней части кроны деревьев (Solomon, 1992, р. 299). Исследовательница видит признаки связи гендера с идеей течения времени еще и в представлениях бушменов о том, что кровь уже течет, когда приходят дожди.

Представления об угрожающем характере женской сексуальности господствуют, как выясняется, не только у австралийских аборигенов дьирбал (что так поразило Дж. Лакоффа ${ }^{8}$ ), но и у бушменов, а также в культурах охотников-собирателей по всему свету (Moore, 1988). Женское начало вообще и его сексуальная сторона в частности ассоциируются с угрозой, с очевидными негативными потенциями и со способностью тормозить процесс воспроизведения новых генераций в общине (см. подробнее в главе 4 книги Лакоффа, раздел «Женское начало как гендерный архетип»). В верованиях бушменов, считает Соломон, эти коннотации проистекают из мифа о девочке, которая нарушила заповеди, покинув во время инициации место, где она должна была пребывать в изоляции (хижина в лесу) на протяжении 4-5 дней.

Забавную иллюстрацию такого положения вещей мы видим у бушменов !кунг. Они используют в качестве яда для отравленных стрел суспензии из двух видов жуков. Все особи того из них, который дает более сильный яд, считаются самками, а особи второго самцами (там же, с.294). Впрочем, здесь мы видим некое несовпадение с оценками, которые другой бушменский этнос, $c a н$, придает разным вариациям дождя. Спокойные, живительные осадки они называют «дождем-самкой», а грозы и ливни - опасные, несущие угрозу — «дождем-самцом».

У бушменов $g / w i$ в категорию «женское» также входят перемежающийся дождь и морось, а также все изменения погоды, приходящие с юга. Например, жара и похолодание, то есть те из них, которые несут с собой негативные последствия. Кроме того, сезон дождей вообще. Сюда же помещены солнце и полная луна, идущая на убыль. А вот альтернативные понятия, которые мы находим в категории «мужское». Ветер, ураган, гроза, особенно приходящие с северо-востока или северо-запада. Луна в виде месяца, а также всевозможные метеорологические явления, безразличные либо благоприятные для общины.

\section{Количество, время и цвет в языке другой архаической культуры}

Чтобы судить о том, насколько пирахан уклоняется от стандартов, характерных для прочих «простых» языков, небесполезно познакомиться вкратце хотя бы с одним из них. Мне попалось на глаза описание языка новогвинейских папуасов дугум дани (далее просто «дани»), сделанное с позиций этнографа, который среди прочего рассмотрел принципы категоризации в нем трех названных аспектов реальности. Народ относится

8 Судя уже по заголовку его книги: «Женщины, огонь и опасные вещи» (Лакофф, 2011). 
к категории «ручные земледельцы тропического леса» и, таким образом, отличается от пираха умением культивировать батат и разводить свиней, не отказываясь при этом от охоты и собирательства. То есть их материальная культура находится на значительно более высоком уровне развития.

\section{Числительные}

На странице 129 перевода книги Эверетта читаем:

«...Похоже, у пираха нет счетных слов и чисел! Сначала я думал, что в языке пираха есть слова „один“, „два“ и „много“, что не редкость среди языков мира. Но потом я понял, что те слова, которые я и предыдущие исследователи принимали за числительные, означают только относительно большее или меньшее количество» (Эверетт, 2016, с. 129; курсив мой. - Е. П.).

Первое издание этой книги датируется 2008 годом. Между тем в статье профессионального шотландского психолога П. Гордона, опубликованной четырьмя годами ранее в престижнейшем журнале Science, сказано: «У пираха система счета состоит из двух слов: «hOi» (понижение тона = один) и «hоi» (повышение тона = два). Большие количества обозначаются словом «baagi» или «aibai» (= много)» (Gordon, 2004, p. 496; полужирный мой. - Е. П.).

Этот исследователь проводил эксперименты по способности к счету с шестью мужчинами и одной женщиной пираха во время трех посещений четы Эвереттов прямо в месте их исследований.

Кстати сказать, он пишет, что хотел проверить в своей работе справедливость точки зрения Уорфа и убедился в том, что тот был прав: «Результат экспериментов... показал, что неспособность к счету [у пираха] очевидным образом обусловлена отсутствием развитой системы соответствующих слов в их языке» (Gordon, 2004, p. 496; курсив мой. - Е. П.). Можно видеть, что этот вывод кардинально противоречит точке зрения самого Эверетта.

Согласно Эверетту, система счета отсутствует за ее ненадобностью. Хейдер, изучавший язык дани, не согласен с таким объяснением, которое он называет «разновидностью софистики» (Heider, 1970/2006, p. 172). В языке дани количество числительных и счетных слов не намного больше, чем у пираха. Здесь, по словам Хейдера, используются две системы. В первой существуют слова «один» (magiat), «два» (pete) и «три» (henaken). Вторая основана на счете «двойками»: одна (jnagiat), две (то же pete) и pete-pete (четыре), но чаще попросту pete; pete; pete... (там же, p. 170). Автор упоминает также слова со значениями «несколько» и «много».

«В культуре дани, - пишет автор, - максимальные количества объектов, подсчет которых требует хотя бы некоторой аккуратности, варьируют примерно между 15 и 30, например, при оценке числа свиней в крупном стаде или ожерелий из раковин, доставляемых гостями на важное празднество. Кажется, однако, что эти люди держат в памяти скорее общую картину содержимо- го собрания многих объектов, чем их истинное количество» (Heider, 1970, p. 172).

Так, продолжает он,

«присутствуя на празднике, я тщательно подсчитывал, сколько было принесено ожерелий. Позже я обсуждал свои наблюдения с информантом, присутствовавшим там же, пытаясь услышать от него, кто из гостей принес то или другое. Разумеется, он не смог назвать общую цифру, но неплохо помнил многие эпизоды преподнесения подарков» (p. 172).

«У дани мы видим скорее систему перечисления событий (enumeration), чем их подсчета. Например, описывая результаты резни, ее свидетель говорил: „И тогда женщины были убиты, pete, pete, pete, pete, много“. Он не собирался сообщить мне число погибших, а лишь указывал на многократную повторяемость актов насилия» (р.171).

Из сказанного можно сделать следующие выводы. Во-первых, в практике дани определенно есть что считать, и необходимость в счете, как кажется, существенна в плане жизненного благополучия отдельных семей и общины в целом. Но лексика, требуемая для этой цели, не отличается сколько-нибудь существенно от той, что используется пираха. Во-вторых, мера различий в количестве счетных слов явно несопоставима с фундаментальным несходством в общем уровне развития материальных культур двух народов. Все это ставит под сомнение идею Эверетта о том, что особенности языка определяются культурой.

\section{Время}

Несмотря на существенные различия культур дани и пираха, в восприятии хода времени там и тут много общего. В книге Эверетта о категоризации времени у вторых, к сожалению, ничего не сказано, как и о лексике, ее отражающей. Поэтому здесь мы можем полагаться только на слова А.Д. Кошелева из его послесловия к книге Эверетта: «...В языке пираха в принципе не может быть коррелятов столь привычных нам лексических показателей времени, как вчера, сегодня, завтра, утро, вечер, неделя, месяи, и т.д.» (Кошелев, 2016, с.351).

Хейдер пишет: «...Очевидно, что дани не воспринимают время в терминах неких очерченных его отрезков. У них нет слов для обозначения часа, дня, месяца, года, срока жизни» (Heider, 1970/2006, p. 173). Он склонен объяснять это тем, что в местообитаниях дани отсутствует хорошо выраженная сезонность, так что на протяжении всего года люди заняты монотонной работой по посадке корнеплодов и снятию урожая (нечто общее с трактовками Эверетта о влиянии постоянства занятий рыбной ловлей у пираха).

Впрочем, создается впечатление, что Хейдер недооценивает степень дифференцированности понятийного аппарата дани, относящегося к описанию в этом языке фактора времени. По его словам,

9 Событие, периодически случающееся во время столкновений между враждующими коллективами. 
помимо таких общих понятий, как «будущее», «прошлое» и «очень далекое прошлое», в этом языке есть существительные, указывающие на размытые в своих границах отрезки времени внутри суток, а также и обозначающие период в несколько дней как до, так и после текущего момента. Автор уточняет список таких слов, который оказывается довольно обширным: рассвет, утро, полуденные часы, поздний вечер, ночь, а также сегодня, вчера, завтра, позавчера, послезавтра. Во внимание принимаются также фазы лунного цикла.

В общем, кажется очевидным, что в сфере этого раздела лексики дани могут дать пираха чуть ли не сто очков вперед, при том, разумеется, условии, что Эверетт не попытался занизить количество таких слов у пираха, дабы укрепить позиции вынашиваемой им теории. О том, что таких попыток можно опасаться, говорит первый абзац этого раздела. И в самом деле, как следует из его более ранней публикации, их не менее девяти (Everett, 2005).

\section{Обозначение цветов}

Говоря об этом в своей книге, Эверетт опять же предельно лаконичен. На с. 132 он ограничивается тремя с половиной строками, как бы подталкивая читателя убедиться в очередной раз самому в бедности изученного им языка. «[К]ак выяснилось, - пишет автор, - это были не отдельные слова, а словосочетания. Более точный их перевод такой: „кровь грязная“ - черный; „оно видит“ или „оно прозрачное“ - белый; „оно как кровь“ - красный; „оно еще незрелое“ - зеленый».

Боюсь, что такой информации совершенно недостаточно, чтобы провести сколько-нибудь содержательное сравнение с тем, что мы видим у дани. «У них, - пишет Хейдер, - наиболее распространенны две оценки цветности. Одна применяется к объектам светлым и ярким (включая красный), вторая - к темным и тусклым» (Heider, 1970/2006, р.175) ${ }^{10}$. Внутри этих двух категорий существуют пять понятий, которые, по мнению автора, можно считать реально обозначающими цвет (true color terms). Белый (с эталоном белая цапля, также индивид-альбинос); беловатый (попугай какаду, белая глина); рыжевато-оранжевый (масть некоторых свиней, окраска одного из видов горлиц и борода самого Хейдера); зеленовато-голубой (камни для изготовления мотыг, перья некоторых яркоокрашенных видов птиц); ярко-красный; пестрый». Если верить тому, что у пираха таких категорий на одну меньше, то различия между двумя этносами вряд ли следует считать существенными.

Подводя итог сказанному в статье, можно констатировать, что теоретические построения Эверетта скорее уступают по степени правдоподобия взглядам Уорфа, нежели опровергают их.

\section{Литература}

Касевич, В.Б. Минимализм в языке и речи // Российский журнал когнитивной науки. Т. 5. №1. С. 75-80.

Кошелев А.Д. Пираха как пример языка, «застывшего» на начальной стадии эволюции // Послесловие к кн.: Эверетт Д. Не спи - кругом змеи. Быт и язык индейцев амазонских джунглей. М: ЯСК, 2016. С. $341-378$.

Кронгауз М.А. Дэниел Эверетт и Бенджамин Уорф: лингвистические и нелингвистические параллели // Российский журнал когнитивной науки. Т. 5. № 1. С.14-21.

Кун Т. Структура научных революций. М.: Прогресс, 1977.

Лакофф Д. Женщины, огонь и опасные вещи. Что категории языка говорят нам о мышлении. М.: Гнозис, 2011.

Малиновский Б. Избранное. Аргонавты западной части Тихого океана. М.: РОССПЕН, 2004.

Никитин Е.П. Объяснение - функция науки. М.: Наука, 1970.

Панов Е.Н. Парадокс непрерывности. Языковой рубикон: о непроходимой пропасти между сигнальными системами животных и языком человека. М.: ЯСК, 2012.

Панов Е. Н. Человек - созидатель и разрушитель: Эволюция поведения и социальной организации. М.: ЯСК, 2017.

Сорокин П.А. Человек. Цивилизация. Общество. М.: Политиздат, 1992.

Тэрнер В. Символ и ритуал. М.: Наука, 1983.

Эванс-Причард Э. Э. Нуэры. Описание способов жизнеобеспечения и политических институтов одного из нилотских народов. М.: Наука, 1985.

Эверетт Д. Л. Не спи - кругом змеи! Быт и язык индейцев амазонских джунглей. М.: ЯСК, 2016.

Bulmer R. Why cassowary not a bird? A problem of zoological taxonomy among the Karam of the New Guinea Highlands // Man (New Ser.). 1967. Vol.2. No. 1. P.5 - 25. doi:10.2307/2798651

Chagnon N.A. The fierce people.New York: Holt, Rinehart \& Winston, 1968.

Everett D. L. Cultural constraints on grammar and cognition in Pirahã. Another look at the design features of human language // Current Anthropology. 2005. Vol.46. No.4. P.1-69.

Everett D. L. Don't sleep, there are snakes: Life and language in the Amazonian jungle. New York: Pantheon Books, 2008.

Gordon P. Numerical cognition without words: Evidence from Amazonia // Science. 2004. Vol.306. No.5695. P.496-499. doi:10.1126/science.1094492

Heider K. G. The Dugum Dani: A papuan culture in the highlands of West New Guinea.Chicago: Transaction Publishers, 1970/2006.

Moore H. L. Space, text and gender: An anthropological study of the Marakwet of Kenya. Cambridge: Cambridge University Press, 1986.

Newton D. To hunt in the morning by J. Siskind // American Anthropologist. 1974. Vol.76. No.3. P.591-592.

Roberson D., Davies I., Davidoff J. Color categories are not universal: Replications and new evidence from a stone-age culture // Journal of Experimental Psychology: General. 2000. Vol.129. No.3. P.1 - 18. doi:10.1037//0096-3445.129.3.369

Roberson D., Davies I., Davidoff J. B. Color categories are not universal: Replications and new evidence // Theories, technologies, instrumentalities of color: Anthropological and historiographic perspectives / B. Saunders, J. van Brakel (Eds.). Lanham, MD, US: University Press of America, 2002. P.25-35.

Solomon A. Gender, representation, and power in San ethnography and rock art // Journal of Anthropological Archaeology. 1992. Vol.11. No.4. P.291-329. https://doi. org/10.1016/0278-4165(92)90011-Y

\footnotetext{
10 Роберсон с соавторами (Roberson et al., 2000, 2002), которые продолжили исследования Хейдера, позже показали, что весьма похожая система существует за тысячи километров от Новой Гвинеи, у африканского этноса химба.
} 


\title{
Language and Culture - Two Sides of the Same Coin
}

\section{Evgeny Panov}

Severtsov Institute of Ecology and Evolution RAS, Moscow, Russia

\begin{abstract}
This paper is a critique of the views of Daniel L. Everett presented in his book "Don't Sleep, There Are Snakes", which is a commentary on his travel log. The author's description of the Pirahã culture appears superficial and inadequate. We address first of all the astonishing naiveté of the author with respect to his interpretation of kinship terminology, which is quite basic for any social anthropology study. By denying the existence of any mythology in Pirahã, the author impedes any deep analysis of the structure of the society's collective consciousness. Thus, the idea of culture becomes much more shallow and mainly refers to the material culture. The 'principle of immediacy of experience' suggested by the author is highly speculative and can hardly be subjected to empirical testing. Examples of adequate analysis of archaic cultures are given, with references to classical studies of a number of ethnic groups: Karam and Dani people (New Guinea), San and Nuer people (Africa) and some others.
\end{abstract}

Correspondence: Evgeny Panov, panoven@mail.ru, 33 Leninsky prospect, 119071 Moscow, Russia

Keywords: linguistic relativity, gender symbolism, metaphorical categorization, lexical categories, numerals, time, color terms

Copyright (C) 2018. Evgeny Panov. This is an open-access article distributed under the terms of the Creative Commons Attribution License (CC BY), which permits unrestricted use, distribution, and reproduction in any medium, provided that the original author is credited and that the original publication in this journal is cited, in accordance with accepted academic practice.

Received May 29, 2017, accepted March 28, 2018.

\section{References}

Bulmer, R. (1967). Why cassowary not a bird? A problem of zoological taxonomy among the Karam of the New Guinea Highlands. Man (New Ser.), 2(1), 5-25. doi:10.2307/2798651

Chagnon, N.A. (1968). The fierce people. New York: Holt, Rinehart $\&$ Winston.

Evans-Pritchard, E.E. (1940). The Nuer: A description of the modes of livelihood and political Institutions of a Nilotic people. Oxford: Clarendon Press.

Everett, D.L. (2005). Cultural constraints on grammar and cognition in Pirahã. Another look at the design features of human language. Current Anthropology, 46(4), 1-69.

Everett, D L. (2008). Don't sleep, there are snakes: Life and language in the Amazonian jungle. New York: Pantheon Books.

Everett, D.L. (2016). Ne spi - krugom zmei! Byt i yazyk indeitsev amazonskikh dzhunglei [Don't sleep, there are snakes: Life and language in the Amazonian Jungle] (P.S. Dronov, I. V. Mokin, E. N. Panov, Trans. into Russian). M: LRC Publishers. (In Russian).

Gordon, P. (2004). Numerical cognition without words: Evidence from Amazonia. Science, 306(5695), 496-499. doi:10.1126/ science. 1094492

Heider, K.G. (1970/2006). The Dugum Dani: A papuan culture in the highlands of West New Guinea. Chicago: Transaction Publishers.

Kasevich, V. (2018). Minimalism in Language and Speech. The Russian Journal of Cognitive Science, 5(1), pp.75-80.

Koshelev, A.D. (2016). Pirakha kak primer yazyka, «zastyvshego» na nachalnoi stadii evolyutsii. Posleslovie [Piraha as a case of language that stopped on the initial stages of its develop- ment. An afterword]. In Everett D. Ne spi - krugom zmei! Byt $i$ yazyk indeitsev amazonskikh dzhunglei [Don't sleep, there are snakes: Life and language in the Amazonian Jungle] (P.S. Dronov, I. V. Mokin, E. N. Panov, Trans. into Russian) (pp.341-378). M: LRC Publishers. (In Russian).

Krongauz, M. (2018). Daniel Everett and Benjamin Whorf: Linguistic and Non-linguistic Parallels. The Russian Journal of Cognitive Science, 5(1), pp. 14-21.

Kuhn, T.S. (1962). The structure of scientific revolutions. Chicago: University of Chicago Press.

Lakoff, G. (2008). Women, fire, and dangerous things. Chicago: University of Chicago press.

Malinovskii, B. (2004). Izbrannoe. Argonavty zapadnoi chasti Tikhogo okeana [Selected works. The Argonauts of the Western Pacific Ocean]. Moscow: ROSSPEN. (In Russian).

Moore, H.L. (1986). Space, text and gender: An anthropological study of the Marakwet of Kenya. Cambridge: Cambridge University Press.

Newton, D. (1974). To hunt in the morning by J. Siskind. American Anthropologist, 76(3), 591-592.

Nikitin, E.P. (1970). Obyasnenie - funktsiya nauki [Explanation as a function of science]. Moscow: Nauka. (In Russian).

Panov, E.N. (2012). Paradoks nepreryvnosti. Yazykovoi rubikon: o neprokhodimoi propasti mezhdu signalnymi sistemami zhivotnykh i yazykom cheloveka [The Continuity Paradox: The Language Rubicon: On the Unbridgeable Gulf between Animal Communication and Human Language]. Moscow: LRC Publishers. (In Russian).

Panov, E.N. (2017). Chelovek - sozidatel i razrushitel: evolyutsiya povedeniya i sotsial'noi organizatsii [Human as a creator and destroyer: Evolution of behavior and social organization]. Moscow: LRC Publishers. (In Russian). 
Roberson, D., Davies, I., \& Davidoff, J. (2000). Color categories are not universal: Replications and new evidence from a stoneage culture. Journal of Experimental Psychology: General, 129(3), 1 - 18. doi:10.1037//0096-3445.129.3.369

Roberson, D., Davies, I., \& Davidoff, J.B. (2002). Color categories are not universal: Replications and new evidence. In B. Saunders, \& J. van Brakel (Eds.), Theories, technologies, instrumentalities of color: Anthropological and historiographic perspectives (pp.25-35). Lanham, MD, US: University Press of America.
Solomon, A. (1992). Gender, representation, and power in San ethnography and rock art. Journal of Anthropological Archaeology, 11(4), 291-329. https://doi. org/10.1016/0278-4165(92)90011-Y

Sorokin, P.A. (1992). Chelovek. Tsivilizatsiya. Obshchestvo [Man. Civilization. Society]. Moscow: Politizdat. (In Russian).

Turner, V. (1969). The ritual process: Structure and anti-structure. New York: Transaction Publishers. 


\title{
Минимализм в языке и речи
}

\author{
Вадим Борисович Касевич \\ Санкт-Петербургский государственный университет, Санкт-Петербург, Россия
}

\begin{abstract}
Аннотация. В лингвистических разделах своей монографии «Не спи, кругом змеи» Эверетт стремится продемонстрировать уникальные свойства языка пираха - предмета его исследования. Однако его попытки не достигают цели. Так, лексические тоны широко распространены в мире (хотя Эверетт, похоже, относится к ним «с подозрением»). Много внимания уделяется проблеме рекурсии. Согласно Хомскому и многим другим, рекурсия делает коммуникативную систему языком. По Эверетту же, то, что в одном языке достигается без использования правил рекурсии, требует рекурсии в другом языке. Можно предположить, что существует когнитивный механизм, который выбирает наиболее «низкозатратный» вариант для получения оптимального результата.
\end{abstract}

Контактная информация: Вадим Борисович Касевич, vadim.kasevich@gmail.com; 199034, Санкт-Петербург, Университетская набережная, д. 11.

Ключевые слова: минимализм, эссенциализм, низкозатратные когнитивные механизмы, рекурсия, цикличность

(c) 2018 Вадим Борисович Касевич. Данная статья доступна по лицензии Creative Commons "Attribution" («Атрибуция») 4.0. всемирная, согласно которой возможно неограниченное распространение и воспроизведение этой статьи на любых носителях при условии указания автора и ссылки на исходную публикацию статьи в данном журнале в соответствии с канонами научного цитирования.

Статья поступила в редакцию 16 апреля 2017 г. Принята в печать 25 марта 2018 г.

На обложку русского перевода монографии Эстена Даля «Возникновение и сохранение языковой сложности» (Даль, 2009) вынесены некоторые из вопросов, которые, видимо, представляются автору (и/ или издательству) наиболее притягательными для потенциального читателя. Среди вопросов и такой: «Говорят ли сейчас где-нибудь на настолько простых языках, как первобытный „язык Эдема“?». Не имея в своем распоряжении несомненных образцов языка Эдема, можно предположить, что это некий идеальный язык, идеальность которого, среди прочего, проявляется в отсутствии «всего лишнего»' ${ }^{1}$ «Отсутствие всего лишнего» обозначают также термином «эссенциализм» (упоминание только того, что несомненно существенно). В свою очередь, так понимаемый эссенциализм сближается с минимализмом.

Минимализм можно трактовать по меньшей мере трояким образом: в смысле Минималистской Программы Хомского (к ней я буду обращаться лишь эпизодически); как художественный прием и стиль в архитектуре, музыке, дизайне (это, естественно, не будет меня занимать); наконец, как лексему общелитературного языка. Последняя, не будучи термином, отражает очень важные аспекты проблем, которые мы здесь обсуждаем. Иначе говоря, речь пойдет в первую очередь о гипотезе, согласно которой пираха представляет собой «максимально простой» язык: в нем

1 Даль замечает, что «этот принцип подпадает под „постулат релевантности“ Грайса» (Даль, 2009, с.24). используются лишь те языковые средства, которые (абсолютно?) необходимы для получения/передачи информации о данной ситуации.

Начнем с того, что применительно как к языку, так и к речи можно говорить о каком-то разумном балансе между параметрами плана выражения и плана содержания. Нужен некий минимум средств выражения, который позволял бы «оформить» релевантный для номинации и коммуникации набор содержательных «единиц». Иначе в языке и тексте (речи) будет слишком высокий процент омонимии - одной и той же форме будет отвечать слишком много возможностей ее семантизации ${ }^{2}$. Разумеется, всё это достаточно спекулятивно, никто не знает конкретных параметров; обычно называемые величины порядка $50 \%$ избыточности произвольного текста (избыточность явно связана с обсуждаемыми проблемами) вряд ли дают нужное представление об ответе на соответствующие вопросы. К тому же при изучении соотношения формы и содержания заметный количественный уклон в ту или иную сторону чаще всего оценивается поразному: если, скажем, одной и той же семантической «единице» соответствует большой набор слов, то это похвально, это проявление лексического богатства языка, в то время как неразвитость синонимии может расцениваться как своего рода эстетическая ущерб-

\footnotetext{
2 Когда говорят, что язык «боится» омонимии, это нужно понимать со значительными оговорками: надо учитывать, что омонимия часто (правда, желательно указывать, как часто) снимается за счет контекста.
} 
ность (разумеется, здесь полностью игнорируются прагматические установки и многое другое).

Допустим, что возникает задача увеличить объем словаря (когда нужный минимум, о котором говорилось выше, почему-либо не достигнут). Это может быть достигнуто разными средствами: за счет заимствования; лексического расщепления; метафорического переноса и, конечно, использования словообразовательных механизмов в языках, где таковые представлены. Если мы допускаем также фунционально-семантическое равенство между единицами (прежде всего словами) и их коллокациями (устойчивыми сочетаниями типа вооруженные силы), то получаем весьма широкую свободу маневра. В то же время язык, похоже, не очень «любит» расшатывание оппозиции слова и словосочетания, и злоупотребление таким способом выражения сопряжено с определенными обременениями (вроде резкого увеличения объема словаря).

Налагая сказанное выше на язык пираха, получаем следующие варианты разрешения ситуации. Мы не знаем, даже примерно, объем словаря пираха. Но мы видим, что структура слога очень проста (налицо жесткие ограничения на слоговые структуры) - настолько, что, по-видимому, имеющихся ресурсов недостаточно для того, чтобы обслужить словарь. В этих условиях есть два решения. Первое состоит в том, чтобы снять ограничения на длину значимых единиц (практически допустить морфемы, слова неопределенной длительности, а также, вероятно, любые повторения идентичных фонологических единиц - фонем, силлабем). Это явно неэкономное решение, и в естественных языках оно, кажется, неизвестно.

Естественные языки «выбирают» другой путь: наряду с сегментными фонологическими единицами вводятся несегментные (супрасегментные) - тоны; тоны выступают как просодические (чаще всего мелодические) характеристики слогов (силлабем), один и тот же по набору гласных/согласных слог обязательно принимает тот или иной тон из фиксированного фонологического набора, то есть число слогов потенциально умножается на число тонов. Как нетрудно видеть, в такого рода картине оптимально сочетается умножение диакритических средств с сохранением используемых фонологических стратегий. Фактически это самый простой из возможных подходов, и неслучайно, что он известен на материале огромного числа языков (достаточно вспомнить китайско-тибетскую языковую семью), поэтому некоторое удивление Эверетта при «обнаружении» тонов в пираха как чего-то экзотического выглядит странно.

То, о чем выше шла речь, можно назвать морфонологической минимизацией (ср. с «пунктами Трубецкого» при описании задач морфонологии, Трубецкой, 1967). Есть и синтаксическая минимизация, которую проиллюстрируем примером из статьи Се Синьи. Этот автор (Hsieh, 1979) трактует предложение типа Иван дал Петру книгу для Марии следующим образом: Иван дал \& дал книгу \& книгу Петру \& дал для Марии. Тем самым синтаксическое дерево принимает «плоскостной» характер (фактически всего один уровень), а все предикаты автоматически становятся одноместными.
Разница, конечно, в том, что анализ Се Синьи не отражен на поверхности, а аналогичные конструкции в пираха - отражены.

Можно увидеть здесь и аналогии с генеративным анализом, где объединение бинарных составляющих в рамках более сложных конструкций осуществляется за счет вычеркивания тождественных лексем (ср. использование Generalized Transformation в ранней версии Хомского и его же трансформации Merge в Минималистской Программе), то есть развитая синтаксическая иерархия возникает на базе строго бинарных синтагм. В некотором смысле язык здесь развивается от простого к сложному, что выглядит нарушением принципа тяготения к минимализму. Однако в окончательном анализе многое будет зависеть от соотношения поверхностных и глубинных структур: если считать, что только глубинные структуры должны наделяться статусом «подлинных» ${ }^{3}$, то сложные структуры будут своего рода «эпифеноменом». Наконец, тяготение к минимализму в языке пираха, с его консерватизмом и скромным диакритическим ресурсом не «подталкивается» каким бы то ни было внешним давлением (ср. Кошелев, 2016), и «разобранный» (в смысле - на детали) синтаксис сохраняется неопределенно долго.

Еще один ракурс рассмотрения нашего языка, связанный с характером синтаксического дерева, также представляется небезынтересным.

В принципе, вполне возможно совместить преимущественно плоскостной характер синтаксического дерева и реализацию конструкций с многовалентными предикатами. Для этого надо ввести ограничение на число синтаксических уровней, которых не должно быть больше двух; выглядит это так: один уровень формируется глаголом-сказуемым и его актантами, а другой - за пределами основного дерева; в сущности, это сирконстант.

Этот сирконстант, уже выходя в область речи и, очевидно, используя соответствующие интонационные средства, есть все основания трактовать как парцеллят (ср. конструкции русского языка типа Он... тоже пошел. В магазин. Сигарет купить - пример из Шукшина в работе Ванникова, 1990, с.369; парцелляты подчеркнуты).

Разбор модельного примера (про Ивана, Петра и книгу) позволяет перейти и к другой, одной из самых важных для описания пираха, проблеме - проблеме рекурсии, которая безусловно имеет отношение к синтаксической декомпозиции и отсюда к минимализму.

«Традиционно рекурсия, - пишет Эверетт, - понимается как способность „вкладывать“ один объект или процесс внутрь другого объекта или процесса, относящегося к данному типу...» (Эверетт, 2016, с.247). Как мы помним, Хомский считал введение рекурсивных правил основным условием для перехода к Стандартной Теории. Если не использовать рекурсивные правила, то нужно обязательно допустить особые правила типа Generalized Transformation или Merge, уже упоминавшиеся выше. Но если не стремиться

3 Такой подход особенно характерен для генеративной фонологии, где, например, right фонологически трактуется как rixt, sign как siүn и т.п. 
к раннему переходу к терминальной цепочке4, а пользоваться правилами переписывания типа S $\rightarrow \mathrm{NP}$ VP; ... $\mathrm{NP} \rightarrow \mathrm{S}$, то процесс порождения будет развертываться заново - теоретически бесконечно, как это и положено при подлинной рекурсии.

Нужно, однако, иметь в виду, что существуют разные типы рекурсии. Эверетт, как мы только что видели, рассматривает любую рекурсию как вложение; в литературе тоже механизм рекурсии часто иллюстрируется и использованием правила переписывания, и хрестоматийными примерами типа Bom дом, который построил Джек... или У попа была собака..., где рекурсия «на поверхности». Но действительно ли рекурсия по типу $\mathrm{S} \rightarrow \mathrm{NP} \mathrm{VP} ; \mathrm{NP} \rightarrow \mathrm{S}$ и т.д. (запись упрощена) и рекурсия наподобие У nona была собака... и на могиле написал, что... «изоструктурны»? Еще раз обратимся к понятию вложения. Слово (термин) «вложение» как будто бы предполагает, что есть позииия, куда вставляется некая единица, и имеется сама эта единица. Но когда используется правило переписывания (см. выше), то трудно утверждать, что для «вкладывающейся» единицы зарезервирована некая позиция, вероятно незаполненная, где должна найти свое место данная единица. Здесь могла бы идти речь не столько о вложении, сколько о «переквалификации» соответствующей единицы и замене ею уже представленной составляющей. Кажется адекватным, что в относительно ранних версиях генеративизма термину «правило переписывания» отвечал в качестве синонима термин «правило подстановки».

Итак, термин «рекурсия» покрывает разные, пусть и соотносящиеся, процессы. Но насколько вообще необходимы для описания языковых структур представления о механизме рекурсии? Прежде всего, каков его приспособительный эффект? Пожалуй, использование в речи рекурсивных структур скорее создает трудности для восприятия речи. Так, бесконечное наращивание длины предложения при вложении (например, при вложении атрибутивных конструкций) на каком-то этапе просто мешает осмыслению текста, поскольку слушающий (в силу ограничений памяти) утрачивает способность следить за нанизывающимися «матрешечными» конструкциями.

Эверетт, соглашаясь с толкованием рекурсии как важного синтаксического средства, выражает сомнения в его универсальности. Не без иронии он пишет: «Если я могу соединить вместе слова, чтобы получить предложение, и предложения, чтобы получить связный текст, то это рекурсия [?]» (Эверетт, 2016, с. $248-249)$. «Значение рекурсии сильно преувеличено, - читаем мы в другом месте. - Вероятно, всё, что можно сказать на одном языке с помощью рекурсии, можно выразить на другом без нее» (Эверетт, 2016, с. 247). Еще более заостряя проблему, можно сказать, что синтаксис пира-

\footnotetext{
4 Упомянутое здесь «стремление» - не спекулятивная гипотеза, оно подкрепляется экспериментальными данными: на материале русского и испанского языков показано, что при инструкции «Продолжите цепочку слов!» испытуемые выбирают из объективно доступных такие варианты, которые обеспечивают кратчайший путь к завершению предложения (Касевич, Новикова, 2016)
}

ха, по-видимому, не обладает техническими средствами, позволяющими одно предложение вводить в состав другого, то есть пираха оперирует только простыми предложениями.

И все же трактовка рекурсии, представленная в предыдущих строках, недостаточно акцентирует другую сторону обсуждаемого явления. Заключается она в том, что структура языка приобретает значительно большую прозрачность, если, пользуясь рекурсивными правилами, мы представим ее (структуру) как минимальныц̆ набор предложений, частично однотипных и частично же позволяющих вложение одного в другое

В логико-математической литературе рассматриваются также понятия изикла и ициличности, и большинство авторов, по-видимому, исходят из эквивалентности (или по крайней мере существенной близости) этих понятий понятию рекурсии. Одно время в лингвистике активно обсуждалось понятие «трансформационного цикла» (Chomsky, Halle, 1968). Из имеющихся внелингвистических определений цикла ближе всего к толкованиям рекурсии описание иикла программы: «многократно используемый в процессе вычисления участок программы» (Глушков, 1979, с.585). Заслуживает внимания и подход к циклу как к цепи графа, «содержащей хотя бы одно ребро, у которого конечная вершина совпадает с начальной» (там же, с. 584).

Представляется, что в области гуманитарных дисциплин оправданны и более широкие представления о циклах и цикличности. Прежде всего, архаические трактовки времени - это в типичном случае трактовки времени как цикла - или как ритма, что в данном случае практически одно и то же (ср., например: Касевич, 1996/2004). Иначе говоря, архаическое сознание, «воспитанное» постоянно воспроизводящимися ритмами/циклами в организме, природе и обществе, именно в этих терминах строит свою картину мира.

Цикличность мира («конечная вершина совпадает с начальной») делает более или менее иррелевантными представления о начале и конце. Категории субъекта и объекта тоже становятся взаимообратимыми. Это прекрасно выражено древнекитайским мудрецом Чжуанцзы: «Однажды Чжуану Чжоу приснилось, что он - бабочка <... [OH] наслаждался от души и не сознавал, что он - Чжоу. Но вдруг проснулся, удивился, что [он] - Чжоу, и не мог понять: снилось ли Чжоу, [что он - бабочка], или бабочке снится, [что она] - Чжоу» (Мудрецы Китая, 1994, с. 138).

Говоря о мировоззренческих категориях, отражающихся в языке пираха, нельзя не упомянуть так называемый принцип непосредственного восприятия (ПНВ). Вообще говоря, если бы это было так, как считает Эверетт, то вряд ли в языке пираха была бы грамматическая категория эвиденииальности, содержание которой именно в том и заключается, чтобы противопоставлять (грамматически!) ситуации, отражающие непосредственный опыт говорящего, 5 Ср., например, не раз переиздававшееся и переводившееся
пособие Хорнби (Hornby, 1975). 
ситуациям, о которых говорящему известно через посредников, понаслышке и т.п. ${ }^{6}$

Если мы отвлечемся от указанного противоречия (или, во всяком случае, странности), то рассуждать можно примерно следующим образом (ср. Выготский, 1982). В онтогенезе знак естественного языка, который призван идентифицировать вещь и отличать данный знак от всех прочих, приблизительно до двухлетнего возраста воспринимается ребенком как один из признаков вещи-денотата наряду с формой, текстурой, цветом и т.п. Позднее приходит эмансипация знака от его денотата, но тесная связь между ними, естественно, сохраняется. Она проявляется прежде всего в том, что закрепляется зависимость «есть слово (знак) - ищи вещь», от которой этот знак «отпочковался». Знаки (слова́) не берутся из «ниоткуда», они суть остаточные компоненты своего рода синкретов.

Наивная психология идет дальше. Она склонна настаивать и на обратной по направлению зависимости: «есть вещь - должно быть и слово» (примерно как в старом анекдоте про поручика Ржевского). Иначе говоря, наивная психология носителя языка тяготеет к ситуативному восстановлению того синкрета, который существовал в раннем онтогенезе

Принцип синкретичности слова-вещи, как можно назвать то соотношение, о котором говорилось выше, и «принцип непосредственности восприятия (ПНВ)» хорошо согласуются. Пираха, можно сказать, живут в «витгенштейнианском» мире - в том смысле, что для них вербальное и реальное изоморфны друг другу, притом их соотношение неизменно. Отсюда и абсолютная убежденность в том, что духи столь же реальны, сколь обычные люди (ведь слово «духи» есть!), и совершенно гераклитовский вопрос по поводу вынырнувшего героя повествования: это тот же самый персонаж, который на глазах у говорящего погружался под воду, или нет?

При рассмотрении соответствующих вопросов, по-видимому, надо учитывать и пронизывающий все сферы жизни консерватизм пираха - их глубокую веру в то, что мир не меняется в некоторых релевантных отношениях. Так, если известно, что каноэ умеют делать лишь мастера из деревни Пау-Кеймаду, то пираха будут настаивать, что они (пираха) не владеют соответствующими навыками - хотя опыт показывает, что на самом деле это не вполне отвечает действительности (Эверетт, 2016).

И еще одна параллель здесь определенно напрашивается. Я имею в виду работы Александра Романовича Лурия (Лурия, 1979), а позднее Пеэ-

\footnotetext{
6 Очень часто формы эвиденциалиса развиваются в соответствующих языках из перфекта, как это имеет место в турецком языке, cp. Ahmet gelmiș 'Ахмет пришел', что имеет также значение 'пришел, потому что вот его пиджак висит' (и т.п.). Но в языке пираха нет перфекта, то есть этот путь развития эвиденциалиса закрыт.

7 Любопытно, что наивная психология здесь в известном смысле смыкается с психологией ученого, прежде всего лингвиста. Для лингвиста типичен исследовательский подход, когда он ищет существенные признаки, например предложения, сама по себе реальность которого обычно не подвергается сомнению (за исключением некоторых направлений): ведь слово такое (предложение) есть. Здесь можно говорить о реификации - овеществлении абстрактного понятия и отражающего его знака (слова).
}

тера Тульвисте (Тульвисте, 1988) и др. о влиянии типа культуры на восприятие мира. Можно вспомнить, как решали (точнее, не решали) классические аристотелевские силлогизмы представители архаических культур. В ответ на вопрос, какого цвета медведи на Новой Земле, где все медведи белые, информанты, вместо того, чтобы ссылаться на большую посылку, заявляли, что они никогда не бывали на Новой Земле. Здесь и ПНВ, и роль культуры, и многое другое.

Временами Эверетт впадает в преувеличение, утверждая, например, что «грамматика менее важна, чем нам представляется» (Эверетт, 2016, с. 224). Вспоминается прямо противоположное по смыслу высказывание Александра Алексеевича Холодовича: «Слова ничто, конструкции - все!». Думается, в обоих высказываниях сквозит некоторый «экстремизм».

Есть к текстам Эверетта общее методическое замечание. Когда занимаешься полевыми исследованиями, работаешь с новым, неизвестным материалом, весьма желательно учитывать как минимум два обстоятельства. Во-первых, необходимо освоить «технологию» полевых исследований (см., напр., Kibrik, 1977), включая методику разработки анкет для испытуемых и т.п.; во-вторых, полезна постоянная оглядка на возможные типологические параллели: они не обладают доказательной силой для решения соответствующих задач, но помогают более осмысленно подойти к проблеме, избежать «теоретического шока» (наподобие «открытия» фонологических тонов в пираха).

В заключение этих кратких заметок можно сказать, что работы Эверетта не зря вызвали большой интерес лингвистов, психологов, этнологов и других специалистов в области (широко понимаемой) антропологии. Автор изучает весьма нетривиальный материал классическим методом включения. Вероятно, для лингвиста этот ценнейший материал (добытый отнюдь не кабинетным ученым) интересен прежде всего демонстрацией того минимального семиотического багажа, который необходим, чтобы система достаточно эффективно выполняла роль естественного языка.

\section{Литература}

Ванников Ю. В. Парцелляция // Лингвистический энциклопедический словарь. М.: Сов. энциклопедия, 1990.

Выготский Л. С. Проблемы общей психологии // Собрание соч.: В 5 т. Т. 2. М.: Педагогика, 1982.

Даль Э. Возникновение и сохранение языковой сложности. M.: URSS, 2009.

Касевич В. Б. Буддизм. Картина мира. Язык. СПб.: Центр «Петербургское востоковедение», 1996/2004.

Касевич В. Б., Новикова М. Ф. Линейное прогнозирование в речи: Эскиз экспериментальной методики и некоторые теоретические соображения (на материале русского и испанского языков) // Мова. Мовлення. Комунікація: Збірка статей на честь ювілею О.І. Стеріополо. Киев: Вид. центр КНЛУ, 2016. С.77-95.

Кошелев А.Д. Пираха как пример языка, «застывшего» на начальной стадии эволюции // Послесловие к кн.: Эверетт Д. Не спи - кругом змеи. Быт и язык индейцев амазонских джунглей. М: ЯСК, 2016. С. 341-378. 
Лурия А.Р. Язык и сознание. М.: МГУ, 1979.

Мудрецы Китая: Ян Чжу, Лецзы, Чжуанизы / Перев. с кит. Л.Д. Позднеевой. Санкт-Петербург: Петербург - XXI век, Лань, 1994.

Словарь по кибернетике / Под ред. В.М. Глушкова. Киев: Энциклопедия, 1979.

Трубецикой Н. С. Некоторые соображения относительно морфонологии. Пражский лингвистический кружок. М.: Прогресс, 1967.

Тульвисте П. Культурно-историческое развитие вербального мышления. Таллин: Валгус, 1988.
Эверетт Д. Не спи - кругом змеи. Быт и язык индейцев амазонских джунглей. М.: ЯСК, 2016.

Chomsky N., Halle M. The sound pattern of English. New York: Harper and Row, Inc., 1968.

Hornby A.S. Guide to patterns and usage in English. Oxford: Oxford Universtiy Press, 1975.

Hsieh H.-I. Logical, syntactic and morphological notions of subject // Lingua. 1979. Vol.48. No.4. P.329-353.

Kibrik A. The methodology of field investigations in linguistics.The Hague/Paris: Mouton, 1977. 


\title{
Minimalism in Language and Speech
}

\section{Vadim Kasevich}

Saint Petersburg State University, Saint-Petersburg, Russia

\begin{abstract}
In the linguistic sections of his book "Don't sleep, there are snakes", Daniel Everett tries to demonstrate the highly unique nature of the Piraha language. Yet, in most cases his claim is not substantiated by actual facts. For instance, contrary to Everett's assertion, lexical tones are widely attested in diverse languages, including Chinese and Kwa. There is great focus on the problem of linguistic recursion. According to Noam Chomsky and many others, recursion rules are required for a communication system to become a language. Everett, meanwhile, emphasizes that what is easier to do in one language using recursion may be simply less difficult in another without recursion. It may be suggested that there is a special cognitive mechanism that selects the less costly option for achieving an optimal result.
\end{abstract}

Correspondence: Vadim Kasevich, vadim.kasevich@gmail.com, 11 Universitetskaya quay, Saint Petersburg State University, 199034, St. Petersburg, Russia

Keywords: minimalism, essentialism, low-cost cognitive options, recursion, cyclicity

Copyright (C) 2018. Vadim Kasevich. This is an open-access article distributed under the terms of the Creative Commons Attribution License (CC BY), which permits unrestricted use, distribution, and reproduction in any medium, provided that the original author is credited and that the original publication in this journal is cited, in accordance with accepted academic practice.

Received April 16, 2017, accepted March 25, 2018.

\section{References}

Chomsky, N., \& Halle, M. (1968). The sound pattern of English. New York: Harper and Row, Inc.

Dahl, Ö. (2004). The growth and maintenance of linguistic complexity. Amsterdam: John Benjamins Publishing.

Everett, D. (2008). Don't sleep, there are snakes: Life and language in the Amazonian jungle. New York: Pantheon Books.

Glushkov, V.M. (Ed.). (1979). Slovar po kibernetike [Dictionary in cybernetics]. Kiev: Entsiklopedia. (In Russian).

Hornby, A.S. (1975). Guide to patterns and usage in English. Oxford: Oxford Universtiy Press.

Hsieh, H.-I. (1979). Logical, syntactic and morphological notions of subject. Lingua, 48(4), 329-353.

Kasevich, V.B. (1996/2004). Buddism. Kartina mira. Yazyyk [Buddhism. Worldview. Language]. Saint Petersburg: Tsentr "Peterburgskoe vostokovedenie". (In Russian).

Kasevich, V.B., \& Novikova, M.F. (2016). Lineinoe prognozirovanie v rechi: Eskiz eksperimental'noi metodiki i nekotorye teoreticheskie soobrazheniya (na materiale russkogo $\mathrm{i}$ ispanskogo yazykov) [Linear prognosis in speech: a sketch of an experimental technique and some theoretical considerations]. In Mova. Movlennya. Komunikatsiya: Zbirka statei na chest' yuvileyu O.I. Steriopolo [Language. Speech. Communication. Paper collection for O.I. Steriopolo's Jubilee] (pp.77-95) Kiev: Vyd. tsentr KNLU.

Kibrik, A. (1977). The methodology of field investigations in linguistics. The Hague/Paris: Mouton.
Koshelev, A.D. (2016). Pirakha kak primer yazyka, "zastyvshego" na nachalnoi stadii evolyutsii. Posleslovie [Piraha as a case of language that stopped on the initial stages of its development. An afterword]. In Everett D. Ne spi - krugom zmei. Byt $i$ yazyk indeitsev amazonskikh dzhunglei [Don't sleep, there are snakes: Life and language in the Amazonian Jungle] (P.S. Dronov, I.V. Mokin, E.N. Panov, Trans. into Russian) (pp.341-378). Moscow: LRC Publishers. (In Russian).

Luria, A.R. (1979). Yazyk i soznanie [Language and consciousness]. Moscow: Moscow State University. (In Russian).

Mudretsy Kitaya: Yan Chzhu, Letszy, Chzhuantszy [The great thinkers of China. Yang Zhu, Leizi, Zhuang Zhou] (1994). Saint Petersburg: Petersburg-XXI, Lan.

Trubetskoy, N.S. (1967). Nekotorye soobrazheniya otnositelno morfonologii [On Morphonology]. In Prazhskiy lingvisticheskiy kruzhok [Prague Linguistic School] (pp.115-118). Moscow: Progress. (In Russian).

Tulviste, P. (1991). The cultural-historical development of verbal thinking. Hauppauge, NY, US: Nova Science Publishers.

Vannikov, Y.V. (1990). Partsellyatsiya [Parcelling]. In Lingvisticheskiy entsiklopedicheskiy slovar [Linguistic encyclopedic dictionary] Moscow: Sov. Entsiklopediya. (In Russian).

Vygotsky, L.S. (1982/1987). Problems of general psychology. In The collected works of L.S. Vygotsky (vol. 1). New York: Plenum Press. 
Принцип

непосредственности

восприятия:

критическая оценка

\author{
Андрей В. Никулин
}

Университет Бразилиа, Бразилия

Аннотация. В статье критически обсуждается гипотеза Дэниела Эверетта о существовании когнитивного ограничения, известного как принцип непосредственности восприятия, свойственного (согласно этой гипотезе) индейцам пираха. Особое внимание уделено лингвистическим фактам, на которых основывается эта гипотеза, в том числе связанным с вопросами о наличии в языке пираха отдельных типов вложенных конструкций (вложенных посессивных конструкций, придаточных предложений, конструкций с глаголом речи с отношением подчинения). Кратко пересказывается дискуссия о языковых особенностях пираха и их связи с рассматриваемым принципом, начатая группой лингвистов в 2009 году, а также обсуждаются некоторые аспекты исследования языков монолингвальных сообществ и интерпретации данных, полученных исследователями в таких сообществах. Автор статьи приходит к выводу, что аргументация Дэниела Эверетта не обладает силой, достаточной для признания валидности принципа непосредственности восприятия.

Контактная информация: Андрей В.Никулин, andre.n.guzman@gmail.com; Programa de Pós-Graduação em Linguística (PPGL) - Departamento de Linguística, Português e Línguas Clássicas (LIP) - Instituto de Letras (IL) - Uninversidade de Brasília (UnB) ICC Sul - B1 72 (mezanino) - Campus Darcy Ribeiro Asa Norte - Brasília, Distrito Federal 70.910-900 Brasil.

Ключевые слова: пираха, принцип непосредственности восприятия, вложенные конструкции, рекурсия, ениверсальная грамматика

(c) 2018 Андрей В. Никулин. Данная статья доступна по лицензии Creative Commons “Attribution” («Aтрибуция») 4.0. всемирная, согласно которой возможно неограниченное распространение и воспроизведение этой статьи на любых носителях при условии указания автора и ссылки на исходную публикацию статьи в данном журнале в соответствии с канонами научного цитирования.

Статья частично основана на материалах более раннего послесловия к книге Д. Эверетта: Никулин А. В. Насколько необычен язык пираха? // Д.Л. Эверетт. Не спи - кругом змеи! Быт и язык индейцев амазонских джунглей. Послесловие. М.: Языки славянских культур, 2016. С. 325-340.

Благодарности. Автор высказывает благодарность фонду CAPES (Coordenação de Aperfeiçoamento de Pessoal de Nível Superior) за аспирантскую стипендию, благодаря которой стало возможным написать эту статью. Кроме того, автор благодарен двум анонимным рецензентам, чьи замечания позволили улучшить ее текст. Возможные неточности или ошибки остаются на совести автора.

Статья поступила в редакцию 17 ноября 2017 г. Принята в печать 20 марта 2018 г. 


\section{1. Изучение связи между языком и культурой}

Исследование взаимодействия между языком и культурой интенсифицировалось со времен Франца Боаca, Эдварда Сепира и Бенджамина Уорфа, однако консенсуса относительно того, какие особенности отдельных языков могут объясняться культурными (и, шире, экстралингвистическими) причинами, до сих пор не достигнуто. Единственной областью языка, проницаемость которой для влияния культурных факторов обычно не подвергается сомнению, оказывается лексика (при этом взаимосвязь может быть весьма нетривиальной, как, например, корреляция между особенностями содержания домашних животных и системой специальных терминов для обращения к ним, наблюдаемая в языках юго-западной Амазонии (Dienst, Fleck, 2009, p. 229-231); см. также подборку примеров в работе Марселя Данези (Danesi, 2004, p. 140-146)). Не предпринимается попыток объяснять культурными причинами факты из области фонетики и фонологии, что неудивительно: эти уровни языка не вовлекают наделенных значением единиц 1 .

Менее прозрачна ситуация с морфологией, синтаксисом, структурой дискурса. Несмотря на то, что гипотезы о культурных коррелятах синтаксических и морфосинтаксических явлений эпизодически выдвигаются (помимо обсуждаемой в настоящем выпуске гипотезы Дэниела Эверетта, можно вспомнить экзотическую попытку объяснить существование конструкций с эргативным строем в языках семьи же проактивностью и целеустремленностью носителей этих языков (Kracke, 2009)), подобные построения обычно не рассматриваются научным сообществом за отсутствием способа доказать существование причинноследственной связи.

В отличие от многих других регионов мира, в Бразилии этнолингвистический подход к исследованию местных языков весьма силен ${ }^{2}$. Во многом это обусловлено тем фактом, что индейские языки используются практически исключительно в деревнях с традиционным укладом жизни; принятие западных культурных норм, как правило, влечет за собой переход сообщества на португальский язык. В этой связи не подвергается никаким сомнениям невозможность существования

\footnotetext{
1 Согласно некоторым авторам (cp. Everett, 2013), можно установить корреляцию между определенными особенностями инвентарей фонем и географическими условиями области распространения языков (но не элементами культуры). Впрочем, часть научного сообщества к подобным утверждениям относится скептически, указывая на статистические проблемы в интерпретации данных (Hammarström, Güldemann, 2014, p.90, footnote 2). Кроме того, существование корреляции еще ничего не говорит о наличии или о направлении причинно-следственных связей; подробнее об этом виде ошибок в лингвистических исследованиях см. работу Шона Робертса и Джеймса Винтерса (Roberts, Winters, 2013).

2 Огромное влияние на формирование современной парадигмы гуманитарных исследований в Бразилии оказал неоэволюционист Дарси Рибейру (1922-1997). В последние годы заметен расцвет исследований, ориентированных на сохранение традиционного знания коренных народов Бразилии, в противовес исследованиям, выполняемым в западной (колониальной) научной парадигме; о конфликте этих двух подходов в полевой лингвистике см. в работе Керен Райс (Rice, 2012, p.425-427).
}

языка вне культуры, и язык может рассматриваться даже как собственность пользующегося им народа (о последствиях этого явления, типичного для обеих Америк, для полевого лингвиста на примере нинилчикского диалекта русского языка см. (Кибрик, 1998, c. 36-37)). Кроме того, полевая работа лингвиста, как правило, подразумевает его длительное проживание в деревне в т. н. индейской территории (бразильский аналог резерваций), вследствие чего погружение лингвиста в быт и реалии носителей языка неминуемо. Все это делает рассуждения о культурных истоках языковых явлений привлекательными для значительной части бразильской академической средыз ${ }^{3}$ Тем не менее формальный аппарат, который бы позволил доказывать гипотезы о культурной природе лингвистических феноменов (или хотя бы оценивать вероятность того, что их причина действительно в культурных фактоpax), до сих пор не был разработан.

\section{2. Верификация гипотезы о принципе непосредственности восприятия}

На фоне других гипотез о связи культуры и языка выделяется обсуждаемая в настоящем выпуске гипотеза Дэниела Эверетта (Everett, 2005), интересная тем, что предполагает целый комплекс лингвистических последствий одного и того же экстралингвистического фактора. Хотя общепринятой методологии верификации гипотез о связи языка и культуры не существует, представляется, что гипотеза, основанная на системе предпосылок, предлагает простор для значительно более богатого обсуждения, чем в случае с гипотезами, основанными всего на одной предпосылке.

Другой особенностью гипотезы Д. Эверетта является экстракультурный характер постулируемого им принципа: хотя его следствия можно, согласно Д. Эверетту, зафиксировать в языке и в культуре, предполагаемые им когнитивные ограничения не поддаются наблюдению, а могут быть установлены только опосредованно.

Критики гипотезы о существовании принципа непосредственности восприятия (далее ПНВ) в языке и культуре пираха пользуются обеими особенностями, ставя под сомнение как весь комплекс языковых фактов, привлекаемых Д. Эвереттом, так и само существование культурных особенностей, ассоциируемых с ПНВ. Часть критики обращена на саму связь между ПНВ и особенностями языка пираха: утверждается, что ПНВ в оригинальной формулировке не предсказывает особенностей, описанных Д. Эвереттом для языка пираха.

\footnotetext{
3 Например, в работе Аны Суэлли Кабрал с коллегами (Cabral et al., 2015) предпринимается попытка идентифицировать культурные факторы выбора грамматического рода в аравакском языке манши неры. Автору настоящей статьи неоднократно приходилось сталкиваться с мнением, согласно которому несуществование квантификатора со значением 'все' в некоторых языках тупи-гуарани объясняется отсутствием иерархических отношений в сообществах носителей этих языков (несмотря на расхожесть этого мнения, видимо, оно не отражено ни в одной опубликованной работе).
} 
Ниже кратко пересказывается дискуссия о языковых особенностях пираха, инициированная Эндрю Невинсом, Дэвидом Песецки и Силени Родригис в 2009 году; достоверность постулируемых Д. Эвереттом культурных особенностей обсуждается Невинсом и коллегами отдельно (Nevins et al., 2009a).

\section{1. Релевантные особенности языка пираха}

Согласно гипотезе Д. Эверетта (Everett, 2005), ПНВ в языке пираха проявляется в виде ряда синтаксических и лексических ограничений, обсуждаемых в подразделах 2.1.1-5.

2.1.1. Вложенные конструкции. Самым сильным тезисом Д. Эверетта стало утверждение об отсутствии в языке пираха вложенных конструкций. Ограничение затрагивает только конструкции одного и того же типа (Everett, 2005, p. 622) - посессивная конструкция не может быть вложена в посессивную конструкцию (запрет на нанизанные посессивы), а предложение не может быть вложено в предложение (запрет на придаточные предложения). Как указывают Невинс, Песецки и Родригис, определение, данное Д. Эвереттом вложенным конструкциям, страдает от нескольких неоднозначностей. Основываясь на аргументации и примерах из работы Д. Эверетта (Everett, 2005), эти авторы предлагают уточнить формулировку его тезиса следующим образом:

«Составляющая а в пираха может доминировать над составляющей $\beta$ только в одном из следующих случаев: (1) если $\alpha$ и $\beta$ принадлежат к разным синтаксическим категориям (в грубом определении) или (2) если $\beta$ состоит из одного слова» (Nevins et al., 2009a, p. 362).

Таким образом, предполагаемый Д. Эвереттом запрет на вложенные конструкции не подразумевает любых проявлений рекурсии, которая, согласно современным положениям порождающей грамматики (Chomsky, 1995; 1999), проявляется в том числе в способности составляющих итеративно склеиваться в предложения (операцию склеивания составляющих называют Merge). Если бы в языке пираха существовал запрет на рекурсию (такая формулировка предлагается в следующем ответе Эверетта (Everett, 2006)), то порождающая грамматика в ее текущем виде не могла бы объяснить, как в этом языке строятся предложения длиной больше двух слов, поскольку, с точки зрения этой теории, для объединения трех (или большего количества) слов в предложение необходимо последовательно применить операцию Merge больше одного раза (Nevins et al., 2009a, p.362, footnote 11). Формулировка гипотезы Эверетта без использования термина "рекурсия», эксплицитно предложенная в работе Ричарда Фатрелла с коллегами (Futrell et al., 2016), снимает несовместимость между этой гипотезой и современной позицией порождающей грамматики.

Вложенные посессивы. Согласно Д. Эверетту, запрет на вложенные конструкции проявляется, в числе прочего, в невозможности поместить в одном высказывании указание на посессора посессора. Так, фразы (1a-b), приведенные ниже, неграмматичны (Everett, 2009, p. 630).

\section{(1) ПИРАХА}

a. *kóoí hoagí kai gáihii 'íga
Ко'ои сын дочь это верно
'Это дочь сына Ко'ои.'

$\begin{array}{llllll}\text { b. }{ }^{*} \text { kaóoí 'igíai hoagi kai gáihii } & \text { 'íga } \\ \text { кто } & & \text { сын } & \text { дочь это } & \text { верно }\end{array}$

'Это дочь чьего сына?'

При этом речь идет не о семантическом запрете: идею вложенного посессора можно выразить в двух предложениях, то есть паратактически (Everett, 2009, там же), как в примере (1c) ниже.

\section{c. 'ísaabi kai gáihií 'íga. kóoí hoagí 'aisigí -aí}

'Исааби дочь это верно Ко'о сын тот.же-АUX

'Это дочь 'Исааби. Сын Ко’ои - он же.'

В этой связи не вполне ясно, с какой целью Д. Эверетт среди возможных объяснений называет структуру общества пираха, где все со всеми знакомы. Согласно аргументации Д. Эверетта, носителям не приходится оперировать больше, чем одним уровнем обладания, и необходимость выражать значение посессора посессора избыточна. Можно вообразить, что отсутствие необходимости выражать посессора посессора в естественном дискурсе могло бы привести к семантическому ограничению на возможность выразить эту идею, но пример с паратаксисом показывает, что такого ограничения в пираха нет. Кроме того, более общее ограничение на выражение избыточной или тривиальной информации (имплицитно предлагаемое Д. Эвереттом в рамках рассматриваемого аргумента), как кажется, не было описано ни для одного языка мира, в том числе для пираха.

Помимо проблем, возникающих при попытке объяснить, как вывести сформулированное Д. Эвереттом ограничение на вложение посессивных конструкций из ПНВ в его же формулировке (о которых см. также 2.2.1), Невинс, Песецки и Родригис указывают на следующие факты (Nevins et al., 2009a, pp. 365-369).

Во-первых, синтаксические ограничения, напоминающие описанное Д. Эвереттом, встречаются в других языках, например в немецком. Как показано в примеpe (2a) ниже, одним из способов выразить принадлежность по-немецки является родительный падеж.

\footnotetext{
4 Невинс, Песецки и Родригис (Nevins et al., 2009a, p. 369) справедливо замечают, что если бы запрет на выражение вложенного посессора мог бы объясняться тем фактом, что все пираха знакомы со всеми пираха, то ожидалось бы, что и любое выражение обладания (в том числе не вложенного, как 'сын Ко'ои') оказалось бы неграмматичным. Кроме того рассматриваемый аргумент Д. Эверетта никак не объясняет, почему данное синтаксическое ограничение должно распространяться на вложенные посессивные конструкции с вершинами, обозначающими неодушевленный денотат ('каноэ сына Кo'о $u_{\text {', }}$ 'волосы сына Кo'ои' и т.п.).
} 
(2) НЕМЕЦКИЙ

\section{a. [Hans-ens [Auto]] \\ Ганс-GEN машина \\ 'машина Ганса'}

Однако конструкцию с использованием родительного падежа нельзя использовать рекурсивно (Roeper, Snyder, 2005, p. 162): пример (2b) ниже неграмматичен.

$\begin{array}{ccc}\text { b. }{ }^{*}[\text { Hans-ens } & {[\text { Auto-s }} & \text { [Motor }]]] \\ \text { Ганс-GEN } & \text { машина-GEN } & \text { мотор } \\ \text { 'мотор машины Ганса' } & \end{array}$

Это ограничение затрагивает только конструкцию с родительным падежом: синонимичные предложения с использованием других конструкций, как (2c-d), грамматичны.

\begin{tabular}{|c|c|c|c|}
\hline c. [Motor & [von & [Hans-ens] & Auto- $\varnothing]$ \\
\hline мотор & из & Ганс-GEN & машина-DAT \\
\hline
\end{tabular}

'мотор машины Ганса'

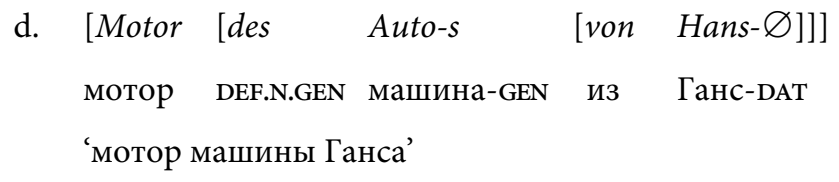

Тот факт, что значение вложенной принадлежности в немецком языке может быть выражено другими способами, говорит о том, что в этом случае речь идет не о семантическом, а о синтаксическом ограничении.

Д. Эверетт (Everett, 2009) отмечает, что существование подобных ограничений в других языках не может быть аргументом против признания существования ПНВ для пираха, так как одно и то же явление может быть следствием разных принципов, имеющих различную природу ${ }^{5}$. Кроме того, он подчеркивает, что ситуация в немецком языке не идентична ситуации в пираха, поскольку в пираха, согласно его данным, запрещено не только преноминальное, но и любое адноминальное выражение посессора второго уровня.

Более сильная критика позиции Д. Эверетта о вложенных конструкциях была предложена Райани Саллис (Salles, 2015) на основании собственных полевых данных и данных Силени Родригис. Этим исследовательницам удалось элицитировать фразы с несомненными нанизанными посессивами, как в примере (3) ниже.

\section{(3) ПИРАХА}

\begin{tabular}{llcl}
{$[[$ Iapohen } & baîi] & \multicolumn{1}{c}{ 'apaitaí] } & kobiaí \\
Иапохен мать волосы & белый \\
'Волосы матери Иапохена седые.' &
\end{tabular}

\footnotetext{
5 Следует отметить, что признание действительным этого последнего утверждения, заведомо применимого ко всем возможным типологическим аргументам, сделало бы невозможной верификацию положения о ПНВ.
}

В качестве стимульного материала Саллис использовала фотографии и рисунки (например, фотографию ее свекрови в черной одежде), однако саму процедуру элицитации она описывает не очень подробно. Как бы то ни было, на настоящий момент конструкции со вложенными посессивами были обнаружены только в элицитированной, но не в естественной речи (Furtell et al., 2016).

Кроме того, возможно, что наблюдавшиеся до сих пор сложности с элицитацией вложенных посессивных конструкций связаны с недостаточным пониманием исследователями синтаксиса посессивных конструкций языка пираха. Согласно новейшим полевым данным Райани Саллис (личное сообщение), носители пираха охотнее признают грамматичность посессивных конструкций (как простых, так и вложенных), если их вершина сопровождается показателем третьего лица, как в примере (4).

(4) ПИРАХА (Райани Саллис, личное сообщение, 2018)

[[[Hiahoái] hi mái'i] 'i 'apaitai] koobiái

Хиахоаи $_{\mathrm{i}} \quad 3_{\mathrm{i}} \quad$ мать $_{\mathrm{j}} \quad 3 \mathrm{~F}_{\mathrm{j}}$ волосы белый

'Волосы матери Хиахоаи седые.'

Таким образом, вероятно, что проблемы с идентификацией вложенных посессивных конструкций в предшествующих исследованиях пираха возникли только потому, что до сих пор исследователи упускали из виду возможность существования в этом языке конструкций с обязательным вершинным маркированием.

Придаточные предложения. Одним из важнейших подтипов вложенных конструкций являются придаточные предложения. Рассматривая приложения типа (5a-b), Д. Эверетт (Everett, 2005, р.629) отвергает возможность анализировать их как сложноподчиненные.

(5) ПИРАХА (Everett, 1986, p. 222; 2005, p. 629)

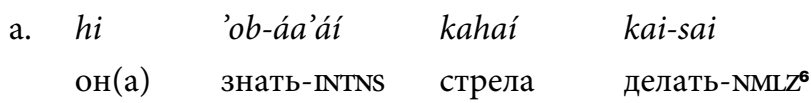

'Он(а) действительно умеет делать стрелы.'

b. 'Oogiái hi 'ob-áa'ái 'apaitiisi

\begin{tabular}{|c|c|c|}
\hline \multirow{2}{*}{\multicolumn{3}{|c|}{$\begin{array}{ccr} & \text { 'ohoai-sai } & \text { hiaitíhi } \\
\text { Оогиаи } & \text { он(a) } & \text { знать-INTNS }\end{array}$}} \\
\hline & & знать-INTNS \\
\hline
\end{tabular}

'Оогиаи действительно умеет говорить на языке пираха, как индейцы пираха.’

Аргументация Д. Эверетта в статье 2005 года (Everett, 2005) основывается на том, что обычный порядок слов в пираха - SOV, и потому интерпретация именных групп kahaí kai-sai и 'apaitíisi 'ohoai-sai как сентенциальных актантов глагола 'ob-áa'áí невозможна, так как в таком случае аргумент О должен был бы

\footnotetext{
6 Д. Эверетт глоссирует -sai как 'номинатив (nominative)'. Как отмечают Невинс, Песецки и Родригис (Nevins et al., 2009a, p. 361; 2009b, p. 673), это следует понимать как опечатку (nominative вместо nominalizer). Правильная глосса встречается, например, в диссертации Эверетта (Everett, 1983).
} 
располагаться между S и V. Вместо этого, как предполагает Д. Эверетт, здесь мы имеем дело с паратаксисом: если kahaí kai-sai и 'apaitíisi 'ohoai-sai не могут быть актантами глагола ob-áa’áí, то единственным выходом оказывается признать, что это клаузы, никак не зависящие синтаксически от предыдущей. Буквально предложения (5a-b) в трактовке Д. Эверетта можно перевести как 'Он(а) умеет. Изготовление стрел' и 'Оогиаи, он умеет. Говорение на языке пираха. Прямо как пираха’.

Невинс, Песецки и Родригис (Nevins et al., 2009a) высказывают сомнение в оправданности аргументации Д. Эверетта. Они отмечают, что нет ничего необычного в том, чтобы сентенциальные актанты вели себя иначе, чем более обычные именные группы, причем в случаях, когда один тип актантов тяготеет к позиции внутри клаузы, а другой - к концу клаузы, обычно к правому концу клаузы стремится именно сентенциальный актант (Dryer, 1980).

Однако похоже, что в случае пираха важным оказывается не столько тип актанта, сколько его громоздкость. Как замечают Невинс, Песецки и Родригис (Nevins et al., 2009a, p.374), в более ранней работе (Everett, 1986, p. 206) Д. Эверетт уже установил принцип, который мог бы объяснить поствербальную позицию объекта в примерах типа (5a-b): даже несентенциальные актанты могут сдвигаться вправо, если они содержат больше пяти или шести слогов, как показано ниже в (6a-b).

(6) ПИРАХА (Everett, 1986, p. 222; 2005, p. 629)

a. $t i$ 'oba-i-sog-abagaí [hiaitíihí ti 'ahaigí]

я видеть-EP-DESID-FRUST.INIT пираха я брат

'Я хочу увидеть моих братьев-пираха.'

b. tiobáhai koho-ái-hiab-a $\begin{array}{ccc}\text { píaii } & \text { tomáti } & \text { gihió-kasí } \\ \text { taí } & \text { píaii }]\end{array}$

ребенок есть-ATEL-NEG-REM помидор вид_фасоли тоже лист тоже

'Дети не едят помидоры, фасоль или зелень.'

Напротив, достаточно короткий сентенциальный актант, как отмечают Невинс, Песецки и Родригис (Nevins et al., 2009a, p. 375), может оказаться в превербальной позиции, как проиллюстрировано в (6c) ниже

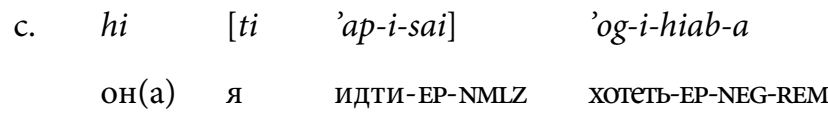

'Он не хочет, чтобы я уходил.'

Таким образом, порядок слов не может служить аргументом против трактовки предложений (5a-b) как сложноподчиненных.

В новейшем анализе (Everett, 2009) Д. Эверетт отказался от того, чтобы интерпретировать -sai как номинализатор. Вместо этого он утверждает, что -sai обозначает «старую информацию» (глосса OLD), и приводит примеры, когда показатель -sai встречает-

\footnotetext{
7 Это наблюдение не настолько сильно, как бы хотелось, поскольку, помимо (6c) (Everett, 1986, p.278), не зафиксирован ни один другой подтверждающий его пример.
}

ся одновременно с дополнительными показателями, характерными для финитных глаголов (хотя и не со всеми) (7a) или обнаруживается на глаголах в главных предложениях (7b).

\section{(7) ПИРАХА}

\section{a. Kóhoi hi kahaí kai-b-íigí-sai \\ Кохои он(a) стрела делать-MOVE:DOWN-CONT-OLD}

'Кохои заканчивает делать стрелы.'

b. Kóhoi 'ob-áa'áí 'áagí-sai

Кохои знать-INTNS быть-OLD

'Кохои разбирается в чем нужно.' (англ. 'Kóhoi really knows his stuff.')

Следует отметить, что этих оснований недостаточно, чтобы отказаться от интерпретации -sai как номинализатора. Во-первых, финитная морфология в определенных случаях вполне может появляться в номинализациях разных типов; так, в хорошо известном Д. Эверетту португальском языке инфинитив может получать показатели лица и числа субъекта (несовместимые с другими именными формами). Во-вторых, как известно, очень часты ситуации, когда в результате реанализа маркеры нефинитности могут переосмысливаться как показатели других глагольных категорий прежде всего, времени или аспекта (Gildea, 2008; Castro Alves, 2010). Как бы то ни было, если в будущем подтвердится, что -sai действительно маркирует «старую информацию», то аргумент Д. Эверетта в пользу трактовки примеров в (5) с использованием паратаксиса оказывается недействительным, поскольку он основывается на номинальных свойствах составляющих c -sai (Nevins et al., 2009b, p.673-674).

Один из самых надежных способов отличить паратаксис от вложенных предложений, а именно анализ сферы действия отрицания, в случае пираха сталкивается с определенными трудностями. Известно, что отрицание в главном предложении в зависимости от семантического типа предиката может наследоваться придаточными предложениями; при паратаксисе наследования отрицания не ожидается. Релевантных примеров зафиксировано немного; см., однако, пример (8) ниже (Everett, 1986, p. 254).

\section{(8) ПИРАХА}

$$
\begin{aligned}
& \text { ti 'ibiib-i-hiab-iig-á kahaí kai-sai } \\
& \text { я приказывать-EP-NEG-CONT-REм стрела делать-NMLZ } \\
& \text { 'Я не приказываю тебе сделать стрелу.' } \\
& \text { или } \\
& \text { 'Я не позволю тебе сделать стрелу.' }
\end{aligned}
$$

Невинс, Песецки и Родригис (Nevins et al., 2009a, p.375) считают, что пример (8) убедительно показывает, что словоформа kai-sai находится в клаузе, подчиненной глаголу 'ibíib-i-hiab-iig-á, поскольку на нее распространяется сфера действия отрицания, расположенного в главном предложении. Однако в более поздних работах Эверетт сообщает, что отрицание 
в примере (8) и других похожих примерах распространяется только на глагол в главном предложении, и предлагает несколько иной перевод примера (8): «Я не приказываю. Ты делаешь стрелу/стрелы». Очевидно, требуется независимое исследование, которое бы специально концентрировалось на сфере действия отрицания главного предложения и связанных с ней семантических явлений, таких как наследование пресуппозиции.

К сожалению, в рамках настоящей статьи нет возможности остановиться на вопросе существования других видов вложенных конструкций, таких как относительные предложения и вопросительные сложноподчиненные предложения, о чем см. в работе Невинса и коллег (Nevins et al., 2009a).

Глагол речи. Упомянутый выше показатель -sai (номинализатор или показатель «старой информации» в зависимости от анализа) имеет необычную особенность: как показано в (9) ниже, в предложениях с косвенной речью он присоединяется не к глаголу цитируемой реплики, как можно было бы ожидать от придаточного предложения, а к самому глаголу речи.

(9) ПИРАХА (Everett, 2005, с. 629)

$\begin{array}{lllll}\text { ti gái-sai } & \text { Kóxoí } & \text { hi } & \text { kaháp-ií } \\ \text { я } & \text { сказать-NMLz } & \text { Кo’ou } & \text { он(a) } & \text { уходить-INTENT }\end{array}$

'Я сказал, что Ко'ои собирается уйти.'

Согласно Д. Эверетту, поскольку придаточных предложений в пираха не существует, буквально предложение (9) устроено так, как показано в буквальном переводе в (9') ниже.

\section{(9') 'Моя речь. Ко'ои собирается уйти.'}

В более поздних работах, как уже было сказано в предыдущем подразделе, Д. Эверетт (Everett, 2009) выступил с гипотезой о том, что на самом деле -saiпоказатель так называемой «старой информации». В таком случае не вполне ясно, почему глагол речи почти всегда сопровождается показателем «старой информации» и какова точная семантика этого показателя. Как бы то ни было, оба анализа Д. Эверетта предполагают, что «Ко’ о собирается уйти» в примере (9) - это отдельное предложение, никаким образом не связанное синтаксически с предложением, обозначающим речевой акт.

Невинс, Песецки и Родригис (Nevins et al., 2009a, p.383) предлагают иную, более подтвержденную типологическими параллелями интерпретацию предложений с косвенной речью. Согласно этим авторам, предложения типа (9) содержат нулевую связку, что позволяет интерпретировать косвенную речь как придаточное предложение, как показано в буквальном переводе в (9") ниже.

(9”) 'Моя речь - что Ко'ои собирается уйти.'

Существование нулевой связки в пираха подтверждается многочисленными примерами, такими как (10).
(10) ПИРАХА (Everett, 1986, p. 205)

$\begin{array}{lll}\text { giopaíi } & \text { hi } & \text { sabí-’i } \\ \text { собака } & \text { он(a) } & \text { дикий-ЕмРН }\end{array}$

'Собака действительно дикая.'

Чтобы выяснить, идет ли в этом случае речь о синтаксическом подчинении или паратаксисе (сочинении), лингвист Ули Зауэрланд (Sauerland, 2015) провел следующий эксперимент. Он попросил носителя пираха по имени Тои произнести некоторые фразы (как обычные, например 'Я посеял кукурузу', так и семантически аномальные, заведомо ложные фразы, например 'Я был на Луне'), а другого носителя он попросил произносить предложения вида 'Тои сказал, что...', записав эти реплики на аудио. Затем другим носителям пираха воспроизводили эти записи в разных сочетаниях и попросили их оценить истинность каждой пары высказываний. Часть комбинаций включала верное цитирование обычного высказывания, часть - ложное цитирование обычного высказывания, часть - верное цитирование аномального высказывания, а часть ложное цитирование аномального высказывания. Например, пара реплик (11) представляет собой пример ложного цитирования обычного высказывания.

(11) Тои:

Я сплю в лодке.

Второй носитель: Tои говорит, что он спит на дереве

Несмотря на некоторые проблемы с интерпретацией некоторыми носителями поставленного экспериментатором задания (часть носителей регулярно отвечали «да» на все вопросы, тогда как другая часть носителей систематически отвечали «нет»), остальные носители, как правило, успешно идентифицировали верное цитирование как обычных, так и аномальных высказываний (частота ответов, соответствующих ожиданиям экспериментатора, оказалась статистически значимой). По мнению Зауэрланда, такой результат возможен тогда и только тогда, когда предложения с глаголом речи вовлекают синтаксическое подчинение. Следует отметить, что вывод Зауэрланда небесспорен: представляется, что истинностная интерпретация сложных предложений не должна непременно зависеть от наличия отношения синтаксического подчинения между их составляющими.

В завершение этого подраздела следует отметить, что отношение подчинения можно выделять не только на синтаксическом уровне, но и на более высоких уровнях - например, на уровне глобальной структуры

\footnotetext{
8 Следует отметить, что в косвенной речи пираха местоимения, обозначающие участников речевого акта, употребляются так же, как ожидалось бы от дословного цитирования (прямой речи): местоимение первого лица относится к автору цитируемого утверждения, а местоимение второго лица - к его собеседнику. Это явление, известное в литературе как indexical shift, отмечено и в других языках, таких как мацес (пано-таканская семья), где это единственный возможный вид косвенной речи (Munro et al., 2012), или грузинский (картвельская семья), где этот способ выражения косвенной речи сосуществует с другими (Aronson, 1990), и не свидетельствует об отсутствии подчинительной связи.
} 
дискурса. Одним из способов формализовать глобальную структуру дискурса является теория риторических структур Уильяма Манна и Сандры Томпсон (Mann, Thompson, 1988), выделяющая около двух десятков возможных типов паратактических (сочинительных) и гипотактических (подчинительных) риторических отношений между пропозициями. Несомненно, в дискурсе пираха нет ограничений на существование гипотактических риторических отношений: даже если принять, что примеры вроде (5a-b) не вовлекают синтаксического подчинения и содержат по две синтаксически независимых друг от друга пропозиции, гораздо сложнее предложить трактовку, в которой бы эти пропозиции не были связаны гипотактическим риторическим отношением ${ }^{9}$.

2.1.2. Квантификация. Д. Эверетт (Everett, 2005) считает одним из следствий ПНВ отсутствие в пираха числительных и счетных слов, полагая, что для того, чтобы оперировать количественными понятиями, необходимо умение обобщать и мыслить абстрактно. Однако он не отрицает наличие в пираха слов вроде hó $i$ 'небольшое количество', hoí ‘большое количество', 'ogió 'все или почти все' и тому подобных; об употреблении таких слов см. подробнее (Frank et al., 2008). Остается не вполне ясным, почему, если ПНВ запрещает выражать точное количество, он же разрешает выражать приблизительное количество (Nevins et al., 2009a, p. 385).

Кроме того, оппоненты Эверетта указывают на то, что в Амазонии известны и другие языки с крайне ограниченными возможностями выражения количества ${ }^{\mathbf{1 0}}$, к чему есть все предпосылки: в сообществах охотников-собирателей, до недавнего времени не участвовавших в торговых отношениях с другими сообществами, умение считать или выражать точные количества не обладает несомненной важностью. Таким образом, вероятно, что в этом случае налицо пример культурнолингвистической связи, который, однако, не имеет никакого отношения к ПНВ

\footnotetext{
9 Манн и Томпсон не включили отношение цитирования (Quote) в список риторических отношений между пропозициями, хотя рассматривали такую возможность (Mann, Thompson, 1988); как отмечает анонимный рецензент, такое отношение было принято и в проекте «Рассказы о сновидениях» (Кибрик, Подлесская, 2009). Следует учитывать, что набор риторических отношений во многом произволен и может быть расширен без ущерба для основ теории риторических структур.

10 Тем не менее следует иметь в виду, что цитируемые Невинсом, Песецки и Родригис со ссылкой на работу Харальда Хаммарстрема (Hammarström, 2006) данные о языках с ограниченными возможностями выражения количества частично основываются на крайне не надежных непервичных источниках. В более надежных источниках числительное '2' зафиксировано в некоторых языках, про которые Х. Хаммарстрем утверждает, что в них нет числительных с точным значением, за исключением ' 1 ': джеоромичи (жабути) dzcbo (Ribeiro, 2008, p.51), кренак ygrimbs (Silva, 1986, p.36; Pessoa, 2012, p. 221; Seki, 2004, p. 139 и др. источники), тимбира aj- $k^{h} r u t / i-p(i) j a-k^{h} r u t$ (Miranda 2014, p. 152; Popjes, Popjes, 1986, p. 186; Castro Alves, 1999, p. 20; Castro Alves, 2004, p. 86). В языке чикитано не отмечено исконного слова для '2', однако систематически используется испанское заимствование tos to:s (диалект ломериано, Sans, 2013, p. 47, 63; Sans, 2010, p.151; Krüsi, Krüsi, 1978, p.68) или to:x (диалект мигеленьо, полевые материалы автора) без каких бы то ни было намеков на приблизительное значение; в диалекте мигеленьо используются и другие заимствованные из испанского числительные, такие как saic ' 6 ' (< исп. seis), с фонетической адаптацией, характерной для давно усвоенных заимствований.
}

Впрочем, Д. Эверетт (Everett, 2009) подчеркивает, что совершенно не важно, подтвердится ли уникальность пираха в этой сфере: во-первых, схожие явления могут быть вызваны разными причинами, во-вторых, он и не заявляет, что пираха - единственный язык с ПНВ.

2.1.3. Видо-временная система. Д. Эверетт отмечает (Everett, 2005), что в языке пираха нет не только грамматической формы, которую можно отождествить с перфектом, но и способа выразить перфектное значение. Этой особенности он дает следующее объяснение. В то время как для видо-временных систем других языков оказывается существенным взаимное расположение на временной оси трех моментов (момента речи, момента события и момента текущей релевантности), в грамматике пираха момент текущей релевантности никак не задействован ${ }^{11}$. Однако такая ситуация наблюдается во многих языках мира, включая литературный русский (Nevins et al., 2009a), и вовсе не обязательно свидетельствует о каких бы то ни было экстралингвистических ограничениях.

Более того, в более поздней работе (Everett, 2009) Д. Эверетт модифицирует свою аргументацию: согласно его новой позиции, ПНВ предсказывает только ограничение на размещение момента текущей релевантности в прошлом или будущем (то есть за пределами непосредственного восприятия). Таким образом, Д. Эверетт все же допускает возможность существования перфекта (но не плюсквамперфекта и не перфекта будущего времени) в пираха и даже приводит один пример, который можно интерпретировать как выражение перфектного значения (Everett, 2009, pp.415, 429), воспроизведенный в (12) ниже.

\section{(12) ПИРАХА}

Kaógiái 'aaboó-p-ái-ta-h-aó
Kaógiái bíooab-á

\section{Каогиаи вернуться-MOVE:UP-AUX-ITER-INTENT-CMPL} Каогиаи уставать-СOMPL

'Каогиаи вернулся, Каогиаи устал.'

Заметим, что никаких специальных тестов по поиску форм или конструкций, которыми можно выразить перфектное значение в пираха, не проводилось. Так, значение перфекта будущего времени можно передать по-русски некоторыми громоздкими конструкциями. Например, рассмотрим французское предложение (13) с использованием перфекта будущего времени.

\section{(13) ФРАНЦУЗСКИЙ (личная компетенция) \\ Tu au-ra-s mang-é- $\varnothing$ ? \\ ты AUX-FUT-2SG есть-PTCP-M \\ 'Ты уже поешь (кмоменту Т)?'}

\footnotetext{
11 Эту гипотезу Д. Эверетт пытается подкрепить следующим наблюдением: когда пираха смотрят на удаляющуюся лодку, они бурно реагируют в момент ее исчезновения за поворотом реки и говорят: «Лодка исчезла», а когда смотрят на приближающуюся лодку, они дожидаются, пока она пристанет к берегу, и в этот момент говорят: «Лодка приплыла». Таким образом, для пираха оказывается важным момент изменения состояния. Тем не менее эта аргументация ничего не говорит о моменте текущей релевантности, а только о том, что совпадение момента речи, момента события и момента текущей релевантности частотно в дискурсе пираха.
} 
Это предложение можно в разных прагматических контекстах перевести как 'Ты успеешь поесть?, ‘'Ты к этому времени уже поешь?' (ср. “‘Ты уже поешь?’). Очевидно, что такие конструкции значительно менее частотны в естественном русском дискурсе, чем во французском (статистический анализ лежит за пределами этой работы), и нет никаких оснований предполагать, что их нет в пираха. Возможно, они существуют, но настолько редки, что просто не встретились в записанных Д. Эвереттом текстах и не были корректно идентифицированы им в речи носителей за время, проведенное им в поле.

Таким образом, в этом отношении пираха, возможно, ничем не отличается от других языков без перфектной системы.

2.1.4. Цветообозначения. Д. Эверетт, комментируя базисные цветообозначения, отобранные в рамках проекта World Color Survey (Kay et al., 2009)'12, отмечает, что все они морфологически производные, как отмечено в (14) ниже, и трактует их не как отдельные лексемы, а как описательные конструкции (Everett, 2005, p. 627).

(14) ПИРАХА

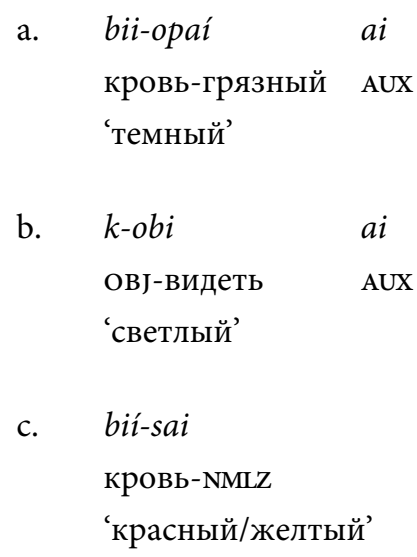
d. ahoas aagá
незрелый временно
'зеленый/синий'

Однако, как справедливо указывается в (Nevins et al., 2009a), это едва ли свидетельствует о чем бы то ни было, кроме того факта, что у цветообозначений, существующих в пираха, есть прозрачная этимология. Того же мнения придерживается специалист по цветообозначениям Пол Кей (Кау, 2005).

Впрочем, Кей обращает внимание на другую особенность, которая как раз могла бы являться следствием ПНВ: согласно Д. Эверетту, цветообозначения пираха (которые он считает описательными конструкциями) не могут использоваться абстрактно (как во фразе 'Мне нравится красный цвет'). Действительно, едва ли можно вообразить более подходящий пример непосредственного восприятия, чем цветное зрение, и неясно, как использование цветообозначения для описания цвета конкретного объекта могло бы нарушать ПНВ. Напротив, субстантивированное использование цветообозначений требует способно-

12 Данные проекта World Color Survey, которому посвящена работа (Kay et al., 2009), доступны онлайн. сти обобщать полученный ранее опыт непосредственного восприятия, и вполне можно вообразить, как он может отсекаться когнитивным принципом, подобным ПНВ.

2.1.5. Система местоимений. Д. Эверетт (Everett, 2005) отмечает простоту системы местоимений в пираха и предполагает, что, поскольку они заимствованы из одного из языков группы тупи-гуарани, на более раннем этапе в пираха их вообще не было. Что касается последнего утверждения, то следует иметь в виду, что личные местоимения заимствуются в самых разных языках мира (хоть и не очень часто): например, в языке нгбака (группа банда, семья убанги) местоимение 2 sG $m \bar{\jmath}$ заимствовано из одного из языков группы нгбанди (семья убанги) (Бабаев, 2013, с.73), энецкие местоимения $y$ 'ты' и бу 'он' (диалект бай) заимствованы из кетского (Сорокина, Володин, 2014, с. 73 ), и т.д. Во всех известных случаях заимствованные личные местоимения ${ }^{13}$ вытеснили исконные местоимения, а не появились с целью заполнить имеющуюся лакуну.

Под сомнение можно поставить и предполагаемую Д. Эвереттом простоту системы местоимений в пираха. Согласно его анализу, в пираха нет местоимений множественного числа, включая 1PL, a есть только три местоимения: $t i(1), g i(2), h i(3)$. Местоимения множественного числа ti'aítiso (1PL), gíaítiso (2PL), hi'aítiso (3PL), упоминающиеся в грамматических описаниях других авторов (например, (Sheldon, 1988)), встречаются и в работах Д. Эверетта, однако он глоссирует их иначе, как показано в (15) ниже.

(15) ПИРАХА

$\begin{array}{ccccc}\text { a. } t i \text { 'aítiso } & b . & g i \text { 'aítiso } & \text { c. } & \text { hi 'aítiso } \\ 1 \text { тоже } & 2 \text { тоже } & & 3 \text { тоже }\end{array}$

Несмотря на глоссу, в переводах конкретных примеров и Д. Эверетт использует местоимение множественного числа, как в примере (16) (Everett, 1986, p.281).

\section{(16) ПИРАХА}

ti 'aítiso 'is ohoa-i-hai
1 тоже еда искать-PRoX-REL.CERT
'Мы будем искать еду.'

В этом смысле остается неясным, чем местоименная система пираха отличается от систем местоимений, представленных в таких языках, как апинаже (группа же, семья макро-же), где для различения числа личных местоимений используются клитики

\footnotetext{
13 Необходимо подчеркнуть, что здесь речь идет только об «универсальныХ» местоимениях 1(sG) и 2(sG). Анонимный рецензент отмечает, что голландский язык в Средние века заимствовал из немецкого рефлексивное местоимение $z i c h$, причем исконное германское местоимение было ранее утрачено в голландском. К этому можно добавить и другие примеры заимствований местоимений вместе с соответствующими категориями - так, в аравакском языке мавайяна имеется местоимение 1EXCL amna, заимствованное из карибского языка вайвай вместе с нехарактерной для аравакских языков категорией клюзивности (Carlin, 2006, p.320)
} 
$w a$ 'DU' и $m \tilde{\varepsilon}$ 'РL', причем последняя может употребляться не только с местоимениями, а и с именами (Oliveira, 2005, p. 172-173). Невинс, Песецки и Родригис (Nevins et al., 2009a, p. 391) приводят другой похожий пример, а именно местоименную систему северокитайского языка, где морфема -men кодирует множественное число местоимений (она же употребляется с некоторыми одушевленными существительными):

$\begin{array}{lll} & \text { SG } & \text { PL } \\ 1 & \text { wǒ } & \text { wǒmen } \\ 2 & n \check{~} & \text { nìmen } \\ 3 & t \bar{a} & \text { tāmen }\end{array}$

Что же касается низкой частотности анафорического местоимения в пираха (Everett, 2005), то едва ли пираха сильно отличается в этом отношении от многих других языков Южной Америки и мира. Так, в диалекте апаньекра языка тимбира (группа же, семья макро-же) единственное местоимение третьего лица $k e$ вообще не может использоваться анафорически (Castro Alves, 2004, p. 82); значение третьего лица в этом языке выражается только личными маркерами.

Наконец, как указывают Невинс, Песецки и Родригис (Nevins et al., 2009a, p. 390), даже если бы в пираха не существовало местоимения 1PL - что, в самом деле, нарушало бы универсалию о существовании по крайней мере местоимений 1SG, 1PL, 2(SG), 3(SG) (Ingram, 1978, p. 227), - неясно, как такое нарушение может следовать из ПНВ.

\section{2. ПНВ и язык}

В этом разделе кратко пересказывается обсуждение связанных с ПНВ проблем, отличных от интерпретации и корректности языковых данных языка пираха.

\subsection{1. Связь между ПНВ и языковыми фак-} тами. Даже если не обращать внимания на вероятные ошибки и неточности в анализе пираха, предложенном Д. Эвереттом, остается неясной другая важная составляющая его гипотезы, а именно сама связь между ПНВ и постулируемыми им синтаксическими и лексическими ограничениями. Д. Эверетт (Everett, 2005, р.622) утверждает, что в соответствии с грамматикой пираха невозможно сообщить более чем об одном событии в одном высказывании, поскольку для носителей пираха, согласно ПНВ, актуален только их непосредственный опыт (опыт самого говорящего или опыт, пересказанный другим живым человеком).

Как отмечают Невинс, Песецки и Родригес (Nevins et al., 2009a), это рассуждение неверно: ПНВ не объясняет, почему одно высказывание не может содержать информацию о двух (или более) событиях, каждое из которых находится в рамках непосредственного опыта говорящего. Например, такое предложение, как «X сказал, [что приближается лодка]», не нарушает ПНВ в формулировке Эверетта: можно допустить, что говорящий мог присутствовать при речевом акте $X$ (непосредственный опыт №1), а о приближающейся лодке говорящему сооб- щил живой человек (непосредственный опыт №2). Таким образом, ограничение на количество событий, которое может быть выражено в одном высказывании, не следует из ПНВ.

Кроме того, даже при предположении, что формулировку ПНВ можно модифицировать так, чтобы из нее следовало ограничение на количество событий в предложении, более общее ограничение на существование вложенных конструкций не получает никакого объяснения. Так, например, в случае нанизанных посессивов выражение дополнительного посессора не приводит к увеличению количества событий: хотя в предложении «В каноэ [моего брата] нашлась пробоина» есть вложенная конструкция, речь в нем идет только об одном событии (Nevins et al., 2009a, p. 364).

Очевидно, что для устранения двух аргументов, приведенных выше, необходимо или изменить саму формулировку ПНВ, или уточнить механизм, при помощи которого ПНВ вызывает запрет на вложенные конструкции в пираха (при условии, что вложенных конструкций в пираха действительно нет).

2.2.2. Последствия ПНВ для Универсальной Грамматики. Д. Эверетт указывает, что лингвистические проявления ПНВ несовместимы с одним из основных положений Универсальной Грамматики о наличии в человеческом языке рекурсивных механизмов порождения предложений. Даже если оставить за рамками этого утверждения положение о том, что более мелкие составляющие рекурсивно склеиваются в более крупные составляющие с помощью операции Merge (о чем см. 2.1.1), с генеративистской точки зрения сам факт присутствия рекурсивных механизмов в человеческой языковой способности (faculty of language) еще не значит, что эти механизмы непременно будут реализоваться в дискурсе. Как заявил Ноам Хомский газете Folha de São Paulo,

«Эверетт надеется, что читатели не разберутся, чем отличается Универсальная Грамматика в техническом смысле (теория о врожденной составляющей человеческого языка) и в неформальном смысле - описание свойств, присущих всем языкам мира. Носители пираха генетически принципиально не отличаются от нас, и дети пираха учат человеческий язык совершенно нормальным образом. Но что, если бы и не могли? Представим, что мы обнаружили сообщество, в котором все ползают вместо того, чтобы ходить, так что дети, выросшие в этом сообществе, вероятнее всего, тоже будут только ползать. Все это не давало бы никакой дополнительной информации о генетических особенностях этого сообщества». Folha de São Paulo (1 февраля 2009 г.) $)^{14}$

Формально это заявление безупречно, однако оно страдает от той же проблемы, что и попытки Д. Эверетта обесценить типологическую критику его данных: если утверждение о существовании универсального ненаблюдаемого принципа иммунно по отношению 
к негативным данным, то оно перестает быть верифицируемым и оказывается за пределами возможностей научного обсуждения ${ }^{15}$.

\section{3. О пределах возможностей в исследовании языков монолингвальных сообществ}

Большинство лингвистов, занимающихся дескриптивной полевой работой, используют в работе с консультантами язык, отличный от исследуемого (русский в случае с малыми языками России, португальский в случае с исконными языками Бразилии и т.д.).

Нередко лингвисты возвращаются из поля, вообще не овладев исследуемым языком. Так может происходить по разным причинам: в частности, из-за отсутствия материалов, по которым лингвист мог бы подготовиться к полевой работе (Everett, 2001), изза необходимости затрачивать время и усилия на изучение местного контактного языка (Newman, Ratliff, 2001) или в ситуациях, когда использование исследуемого языка человеком, не принадлежащим сообществу, по каким бы то ни было причинам неуместно (Mufwene, 1993). Тем не менее в настоящее время большинство антропологов и дескриптивных лингвистов указывают на чрезвычайную важность практического овладения исследуемым языком (cp. Boas, 1911; Dixon, 2007; Moore, 2009) ${ }^{\mathbf{1 6}}$.

Практическое владение исследуемым языком дает лингвисту следующие преимущества (Sarvasy 2015, p. 473-474): (1) снижение интерференции контактного языка, (2) обеспечение исследователя языковым чутьем, полезным для идентификации возможных новых направлений для исследования, (3) доступ к самым компетентным носителям, которые нередко не владеют контактным языком, (4) расширение возможностей по идентификации аграмматичных высказываний, (5) более прозрачная демонстрация намерений исследователя носителям языка, (6) снижение разницы в статусе между исследователем и носителями языка, (7) уточнение переводов записываемых текстов, (8) возможность идентификации неожиданных конструкций в спонтанной речи носителей языка, (9) снижение возможного влияния присутствия исследователя на языковое сообщество и (10) учащение ситу-

\footnotetext{
15 С точки зрения анонимного рецензента, «довод Хомского относительно особенностей УГ в техническом смысле не вполне „иммунен“ по отношению к негативным данным. Например, если бы в каком-то человеческом языке предложения могли состоять не больше чем из 15 слов, идея рекурсивности структуры оказалась бы опровергнутой». По нашему мнению, даже такую гипотетическую ситуацию оказалось бы возможным примирить с положениями Хомского о рекурсивности, предполагая, к примеру, что составляющие могут бесконечно рекурсивно склеиваться в любом языке, однако в этом отдельно взятом языке такая возможность по каким бы то ни было причинам не реализуется.

16 Противоположная точка зрения высказывается, например, в работе Маргарет Мид (Mead, 1939). Согласно Мид (Mead, 1939), для полевой работы достаточно минимальных практических знаний изучаемого языка, и традиционный метод - использование лингвафранка - справляется со своей задачей.
}

аций, благоприятствующих порождению носителями языка спонтанных текстов.

Следует отметить, что в случае такого преимущественно моноязычного сообщества, как пираха, пункты (2-4) и (7-8) оказываются особенно значимыми. Исследователь, имеющий возможность не использовать при работе с пираха португальский язык, оказывается в заведомо выигрышном положении по сравнению с исследователями, вынужденными прибегать к использованию лингва франка. Помимо прямых следствий отсутствия преимуществ (2-4) и (7-8), ожидается, что не владеющий языком пираха исследователь столкнется с серьезными трудностями в постановке задач перед консультантами из-за языкового барьера; так, Ули Зауэрланду (Sauerland, 2015) пришлось отфильтровать данные, полученные от консультантов, не понявших задуманной им формулировки задания.

Не стоит пренебрегать и важностью пункта (9). Маловероятно, чтобы присутствие (особенно кратковременное) исследователей в сообществе пираха могло оказать сколько-нибудь значительное влияние на культуру и язык пираха, однако в последние десятилетия контакт пираха с другими этническими группами (в первую очередь с городскими бразильцами и с индейцами паринтинтин) непрерывно интенсифицируется. До 1985 года обширная территория вдоль реки Маиси контролировалась добывавшими бразильский орех коммерсантами. В результате вмешательства государственной организации FUNAI (Национальный фонд индейцев) и, с 1991 года, организации Cimi (Миссионерский совет по индейцам) пираха восстановили доступ к этой территории и на сегодняшний день занимаются на ней добычей бразильского ореха, который они обменивают на муку, одежду и инструменты с местными коммерсантами через посредничество Cimi' ${ }^{17}$. Некоторые исследователи, убежденные в реальности влияния культуры на язык (например, специалист по токантинскому диалекту языка ава-каноэйру Ариэл Феула ду Коуту и Силва, личное сообщение), предсказывают, что возникающая контактная ситуация может привести к изменениям в культуре, которые, в свою очередь, могут повлиять на язык. Согласно этой точке зрения, исследователи, намеревающиеся работать с пираха в дальнейшем, могут застать язык в состоянии, уже изменившемся под действием указанных факторов по сравнению с состоянием, зафиксированным Эвереттом, и в таком случае его утверждения вообще нельзя подтвердить или опровергнуть.

\section{4. Заключение}

Гипотеза, выдвинутая Д. Эвереттом, основывается в числе прочего на множестве языковых данных, которые, по мнению автора гипотезы, складываются в стройную картину и могут быть объяснены воздействием одного фактора. В подразделе 2.1 резюмирована аргументация скептиков, сомневающихся в корректности описания и анализа языковых данных Д. Эвереттом. В подразделе 2.2 приводятся доводы, критикующие

17 По информации портала Социоамбиентального института (Instituto Socioambiental). 
архитектуру культурно-лингвистической связи, постулируемой Д. Эвереттом. На взгляд автора настоящей статьи, большинство из пересказанных в разделе 2 apгументов обладают достаточной силой, чтобы считать гипотезу о каузальной связи между ПНВ и языковыми особенностями пираха опровергнутой.

Тем не менее отдельные языковые факты пираха (такие как ограничение на абстрактное употребление цветообозначений) представляются необычными и должны быть исследованы более подробно. Больше внимания должно быть уделено и структуре дискурса пираха, а также прагматическим особенностям, характеризующим использование этого языка его носителями. По причинам, перечисленным в разделе 3 , крайне желательно, чтобы дальнейшие полевые исследования пираха проводились с минимальным использованием португальского языка.

\section{Литература}

Бабаев К.В. Нигеро-конголезский праязык. Личные местоимения. М.: Языки славянской культуры, 2013.

Кибрик А.А. Некоторые фонетические и грамматические особенности русского диалекта деревни Нинилчик (Аляска) // Язык. Африка. Фульбе. Сборник научных статей в честь Антонины Ивановны Коваль / Под ред. В.Ф. Выдрина, А.А. Кибрика. СПб.; М.: Европейский дом, 1998. С. 36-52.

Рассказы о сновидениях: Корпусное исследование устного русского дискурса / Под ред. А.А. Кибрика, В.И. Подлесской. М.: Языки славянских культур, 2009.

Сорокина И.П., Володин А.П. Категория личной принадлежности в самодийских языках // Вопросы уралистики 2014. Научный альманах / Под ред. С. Мызникова. СПб.: НесторИстория, 2014. С. 32-85.

Aronson H.I. Georgian: A reading grammar. Bloomington: Slavica Publishers, Inc, 1990.

Boas F. Introduction // Handbook of American Indian languages / F. Boas (Ed.). Washington, DC: Smithsonian Institution, Bureau of American Ethnology, 1911. P.1-83.

Cabral A.S.A.C., Manchinery L.A., Couto F.P., Manchineri M.S.S. Bases culturais para atribuição de gênero em Manxineru // Revista Brasileira de Linguística Antropológica. 2015. Vol.7. No.2. P.321-341

Carlin E. Feeling the need: The borrowing of Cariban functional categories into Mawayana (Arawak) // Grammars in contact: A cross-linguistic perspective / A.Y. Aikhenvald, R.M.W. Dixon (Eds.). Oxford: Oxford University Press, 2006.

Castro Alves, F.de. Aspectos fonológicos do Apãniekrá (Jê). A Master's Thesis. Universidade de São Paulo, São Paulo, 1999. P.313-332

Castro Alves, F. de. O Timbira falado pelos Canela Apãniekrá: uma contribuição aos estudos da morfossintaxe de uma língua Jê. $\mathrm{PhD}$ dissertation. Universidade Estadual de Campinas, Campinas, 2004.

Castro Alves F.d. Evolution of Alignment in Timbira // International Journal of American Linguistics. 2010. Vol.76. No.4. P.439-475. doi:10.1086/658054

Chomsky N. The minimalist program (Current studies in linguistics). Cambridge, MA: MIT Press, 1995.

Chomsky N. Derivation by phase. Cambridge, MA: MIT Press, 1999.

Danesi M. A basic course in anthropological linguistics. Toronto: Canadian Scholars' Press Inc, 2004.

Dienst S., Fleck D.W. Pet vocatives in Southwestern Amazonia // Anthropological Linguistics. 2009. Vol.51. No.3-4. P.209-243. doi:10.1353/anl.2009.0001

Dixon R.M. W. Field linguistics: A minor manual // Focus on: Linguistic Fieldwork. Special issue of Sprachtypol. Univ. Forsch. (STUF).2007.Vol.60.No.1.P.12-31.doi:10.1524/stuf.2007.60.1.12
Dryer M.S. The positional tendencies of sentential noun phrases in universal grammar // Canadian Journal of Linguistics/ Revue Canadienne de Linguistique. 1980. Vol.25. No.2. P.123-196. doi:10.1017/s0008413100009373

Everett $C$. Evidence for direct geographic influences on linguistic sounds: The case of ejectives // PLoS One. 2013. Vol.8. No.6. P.e65275. doi:10.1371/journal.pone.0065275

Everett D. A língua Pirahã e a teoria da sintaxe: Descrição, perspectivas e teoria. $\mathrm{PhD}$ dissertation. Universidade Estadual de Campinas, 1983.

Everett D.L. Pirahã // Handbook of Amazonian languages / D.C. Derbyshire, G. K. Pullum (Eds.). Berlin: Mouton de Gruyter, 1986. P.200-326.

Everett D.L. Cultural constraints on grammar and cognition in Pirahã: Another look at the design features of human language // Current Anthropology. 2005. Vol.46. No.4. P.621-646. doi:10.1086/431525

Everett D.L. Reply to Bambini, Gentili and Pietrini // Current Anthropology. 2006. Vol.47. P. 147-144. doi:10.1086/498952

Everett D.L. Pirahã culture and grammar: A response to some criticisms // Language. 2009. Vol.85. P.405-442. doi:10.1353/ lan.0.0104

Frank M.C., Everett D. L., Fedorenko E., Gibson E. Number as a cognitive technology: Evidence from Pirahã language and cognition // Cognition. 2008. Vol. 108. No.3. P.819-824. doi:10.1016/j. cognition.2008.04.007

Futrell R., Stearns L., Everett D.L., Piantadosi S.T., Gibson E. A corpus investigation of syntactic embedding in Pirahã // PLoS One. 2016. Vol.11. No.3. P.e0145289. doi:10.1371/journal. pone. 0145289

Gildea S. Explaining similarities between main clauses and nominalized phrases // Amerindia. 2008. Vol.32. P.57-75.

Hammarström H. Rarities in numeral systems // Paper presented at Rara \& Rarissima: Collecting and interpreting unusual characteristics of human languages. Leipzig: 2006.

Hammarström H., Güldemann T. Quantifying geographical determinants of large-scale distributions of linguistic features // Language Dynamics and Change. 2014. Vol.4. No.1. P.87-115. doi:10.1163/22105832-00401002

Ingram D. Typology and universals of personal pronouns // Universals of human language, vol. 3: Word structure / J.H. Greenberg (Ed.). Stanford, CA: Stanford University Press, 1978. P.213-247.

Kay P. Commentary on Everett (2005) // Current Antropology. 2005. Vol.46. No.4. P.636-637.

Kay P., Berlin B., Maffi L., Merrifield W.R., Cook R. The world color survey. Stanford, CA: Center for the Study of Language and Information, 2009.

Kracke W. Two ergativities and their cultural correlates // Revista Brasileira de Linguística Antropológica. 2009. Vol.1. No.1. P.13-25.

Krüsi M., Krüsi D. Phonology of Chiquitano. Work papers of the Summer Institute of Linguistics. Riberalta: Summer Institute of Linguistics, 1978.

Mann W.C., Thompson S.A. Rhetorical Structure Theory: Toward a functional theory of text organization // Text. 1988 Vol.8. No.3. P.243-281. doi:10.1515/text.1.1988.8.3.243

Mead M. Native languages as fieldwork tools // American Anthropologist. 1939. Vol.41. No.2. P.189-205. doi:10.1525/ aa.1939.41.2.02a00010

Miranda M.G. Morfologia e morfossintaxe da língua Krahô (família Jê, tronco Macro-Jê). $\mathrm{PhD}$ dissertation. Universidade de Brasília, 2014.

Moore L.C. On communicative competence in the field // Language and Communication. 2009. Vol.29. No.3. P.244-253. doi:10.1016/j.langcom.2009.02.006

Mufwene S. Investigating Gullah: Difficulties in ensuring "authenticity" // Language variation in North American English: Research and teaching / A.W. Glowka, D.M. Lance (Eds.). New York, NY: Modern Language Association, 1993. P.178-190.

Munro R., Ludwig R., Sauerland U., Fleck D.W. Reported speech in Matses: Perspective persistence and evidential narratives // International Journal of American Linguistics. 2012. Vol.78. No.1. P.41-75. doi:10.1086/662637 
Nevins A., Pesetsky D., Rodrigues C. Pirahã exceptionality: A reassessment // Language. 2009a. Vol.85. No.2. P.355-404. doi:10.1353/lan.0.0107

Nevins A., Pesetsky D., Rodrigues C. Evidence and argumentation: A reply to Everett (2009) // Language. 2009b. Vol.85. No.3. P.671-681. doi:10.1353/lan.0.0140

Newman P., Ratliff M. Introduction // Linguistic fieldwork / P. Newman, M. Ratliff (Eds.). Cambridge: Cambridge University Press, 2001. P.1-14.

Oliveira C.C.de. The language of the Apinajé people of Central Brazil. $\mathrm{PhD}$ dissertation. University of Oregon, 2005.

Pessoa K.N. Análise fonética e fonológica da língua Krenak e abordagem preliminar de contos Botocudo. PhD dissertation. Universidade Estadual de Campinas, 2012. URL: http:// repositorio.unicamp.br/bitstream/REPOSIP/270866/1/Pessoa KatiaNepomuceno D.pdf.

Popjes J., Popjes J. Canela-Krahô // Handbook of Amazonian languages / D.C. Derbyshire, G.K. Pullum (Eds.). Berlin: Mouton de Gruyter, 1986. P.128-199.

Ribeiro M.A. Dicionário Djeoromitxí-Português. Registro da diveridade lingüística do povo Jabuti. A Master's Thesis. Fundação Universidade Federal de Rondônia, Campus de Guajará-Mirim, 2008. URL: http://livros01.livrosgratis.com.br/cp084588.pdf.

Rice K. Ethical Issues in Linguistic Fieldwork // The Oxford handbook of linguistic fieldwork / N. Thieberger (Ed.). Oxford; New York, NY: Oxford University Press, 2012. P.407-429.

Roberts S., Winters J. Linguistic diversity and traffic accidents: Lessons from statistical studies of cultural traits // PLoS One. 2013. Vol.8. No.8. P.e70902. doi:10.1371/journal.pone.0070902

Roeper T., Snyder W. Language learnability and the forms of recursion // Linguistik Aktuell / Linguistics Today / A.M. Di Sciullo (Ed.). Amsterdam: John Benjamins Publishing Company, 2005. P.155-169. doi:10.1075/la.75.10roe
Salles $R$. Understanding recursion and looking for selfembedding in Pirahã. The case of possessive constructions. A Master's Thesis. PUC-Rio, Rio de Janeiro, 2015. doi:10.17771/ PUCRio.acad.26480

Sans $P$. Éléments de sociolinguistique et de phonologie du béstro (chiquitano). Langue en danger des basses terres de Bolivie. A Master's Thesis. Université Lumière Lyon 2, 2010. URL: http:// www.ddl.cnrs.fr/fulltext/Sans/Sans 2010 light.pdf.

Sans P. Elementos de la gramática del Béstro: Sociolingüística - Fonología - Morfología - Textos. Con la colaboración de: Lucas Chorez Quiviquivi. San Antonio de Lomerío, Bolivia: Laboratoire Dynamique du Language, 2013.

Sarvasy $H$. Monolingual fieldwork in and beyond the classroom: the Logooli experience at UCLA // Proceedings of CLS. 2015. P. $471-484$.

Sauerland U. False speech reports in Pirahã: A comprehension experiment // To appear in Recursion and embedding in Brazilian languages and beyond 2015. URL: http://ling.auf.net/ lingbuzz/002850.

Seki L. Aspectos da Morfossintaxe Krenak: Orações Independentes // Línguas Indígenas Americanas. 2004. Vol.4. No.1. P.129-146. URL: https://periodicos.sbu.unicamp.br/ojs/index. php/liames/article/view/1431/1421.

Sheldon S.N. Os sufixos verbais Mura-Pirahã // Série Lingüística. 1988. Vol.9. P.146-175.

Silva T.C.A.de. Descrição fonética e análise de alguns processos fonológicos da língua Krenák. A Master's Thesis. Universidade Federal de Minas Gerais, Belo Horizonte, Brazil, 1986. 


\title{
The Immediacy of Experience Principle: A Critical Assessment
}

\section{Andrey Nikulin}

\author{
University of Brasília, Brasil
}

\begin{abstract}
In this article, I discuss the hypothesis put forward by Daniel Everett, according to which a certain constraint, known as the Immediacy of Experience Principle, affects the cognition of the Pirahã people. I devote special attention to the linguistic facts that are crucial for the hypothesis under consideration, including those related to the (non)existence of certain types of embedded constructions (such as embedded possessive constructions, dependent clauses and subordinate constructions with a speech verb). I offer a summary of the discussion on certain particularities of the Pirahã grammar and their relation to the principle under consideration, initiated in 2009 by a group of linguists. I also discuss some aspects of carrying out fieldwork in monolingual societies and interpreting the data obtained in these conditions. I conclude that Daniel Everett's argumentation is insufficient to support the validity of the Immediacy of Experience Principle.
\end{abstract}

Correspondence: Andrey Nikulin, andre.n.guzman@gmail.com, Programa de Pós-Graduação em Linguística (PPGL) Departamento de Linguística, Português e Línguas Clássicas (LIP) - Instituto de Letras (IL) - Uninversidade de Brasília (UnB) ICC Sul - B1 72 (mezanino) - Campus Darcy Ribeiro Asa Norte - Brasília, Distrito Federal 70.910-900 Brasil

Keywords: Pirahã, Immediacy of Experience Principle, embedded constructions, recursion, Universal Grammar

Copyright $\odot$ 2018. Andrey Nikulin. This is an open-access article distributed under the terms of the Creative Commons Attribution License (CC BY), which permits unrestricted use, distribution, and reproduction in any medium, provided that the original author is credited and that the original publication in this journal is cited, in accordance with accepted academic practice.

Note. The article is partially based on an earlier afterword for the Russian translation of Daniel Everett's book: Nikulin, A. (2016). Naskol'ko neobychen yazyk pirakha? [How exceptional is piraha language? Afterword] In D.L. Everett. Ne spi krugom zmei! Byt i yazyk indeitsev amazonskikh dzhunglei [Don't sleep, there are snakes: Life and language in the Amazonian Jungle] (P.S. Dronov, I.V. Mokin, E. N. Panov, Trans. into Russian), pp. 325-340. Moscow: LRC Publishers.

Acknowledgements. I am grateful to CAPES (Coordenação de Aperfeiçoamento de Pessoal de Nível Superior) for providing a scholarship that made it possible to carry out the present study. I am also grateful to two anonymous reviewers, whose comments helped improve the final version of this paper. Any remaining errors are my own responsibility.

Received November 17, 2017, accepted March 20, 2018.

\section{References}

Aronson, H.I. (1990). Georgian: A reading grammar. Bloomington: Slavica Publishers, Inc.

Babaev, K.V. (2013). Nigero-kongolezskii prayazyk. Lichnye mestoimeniya [Nigero-Congo proto-language. Perosnal pronouns]. Moscow: LRC Publishers. (In Russian).

Boas, F. (1911). Introduction. In F. Boas (Ed.), Handbook of American Indian languages, Vol.1 (pp.1-83). Washington, DC: Smithsonian Institution, Bureau of American Ethnology.

Cabral, A.S.A.C., Manchinery, L.A., Couto, F.P., \& Manchineri, M.S.S. (2015). Bases culturais para atribuição de gênero em Manxineru. Revista Brasileira de Linguística Antropológica, 7(2), 321-341.

Carlin, E. (2006). Feeling the need: The borrowing of Cariban functional categories into Mawayana (Arawak). In A.Y. Aikhenvald, \& R.M.W. Dixon (Eds.), Grammars in contact: A cross-linguistic perspective (pp. 313-332). Oxford: Oxford University Press.
Castro Alves, F.de. (1999). Aspectos fonológicos do Apãniekrá (Jê). Unpublished master's thesis, Universidade de São Paulo. (In Portuguese).

Castro Alves, F.de. (2004). O Timbira falado pelos Canela Apãniekrá: uma contribuição aos estudos da morfossintaxe de uma língua Jê. Unpublished doctoral dissertation, Universidade Estadual de Campinas. (In Portuguese).

Castro Alves, F.de. (2010). Evolution of alignment in Timbira. International Journal of American Linguistics, 76(4), 439-475. doi:10.1086/658054

Chomsky, N. (1995). The minimalist program (Current studies in linguistics). Cambridge, MA: MIT Press.

Chomsky, N. (1999). Derivation by phase. Cambridge, MA: MIT Press.

Danesi, M. (2004). A basic course in anthropological linguistics. Vol.2. Toronto: Canadian Scholars' Press Inc.

Dienst, S., \& Fleck, D.W. (2009). Pet vocatives in Southwestern Amazonia. Anthropological Linguistics, 51(3-4), 209-243. doi:10.1353/anl.2009.0001 
Dixon, R.M.W. (2007). Field linguistics: A minor manual. Focus on: Linguistic Fieldwork. Special issue of Sprachtypol. Univ. Forsch. (STUF), 60(1), 12-31. doi:10.1524/stuf.2007.60.1.12

Dryer, M.S. (1980). The positional tendencies of sentential noun phrases in universal grammar. Canadian Journal of Linguistics/Revue Canadienne de Linguistique, 25(2), 123-196. doi:10.1017/s0008413100009373

Everett, C. (2013). Evidence for direct geographic influences on linguistic sounds: The case of ejectives. PLoS One, 8(6), e65275. doi:10.1371/journal.pone.0065275

Everett, D. (1983). A língua Pirahã e a teoria da sintaxe: Descrição, perspectivas e teoria. Unpublished doctoral dissertation, Universidade Estadual de Campinas. (In Portuguese).

Everett, D.L. (1986). Pirahã. In D.C. Derbyshire, \& G.K. Pullum (Eds.), Handbook of Amazonian languages, Vol.1. (pp.200-326). Berlin: Mouton de Gruyter.

Everett, D.L. (2005). Cultural constraints on grammar and cognition in Pirahã: Another look at the design features of human language. Current Anthropology, 46(4), 621-646. doi: $10.1086 / 431525$

Everett, D.L. (2006). Reply to Bambini, Gentili and Pietrini. Current Anthropology, 47, 147-144. doi:10.1086/498952

Everett, D.L. (2009). Pirahã culture and grammar: A response to some criticisms. Language, 85, 405-442. doi:10.1353/ lan. 0.0104

Frank, M.C., Everett, D.L., Fedorenko, E., \& Gibson, E. (2008). Number as a cognitive technology: Evidence from Pirahã language and cognition. Cognition, 108(3), 819-824. doi:10.1016/j.cognition.2008.04.007

Futrell, R., Stearns, L., Everett, D.L., Piantadosi S. T., \& Gibson, E. (2016). A corpus investigation of syntactic embedding in Pirahã. PLoS One, 11(3), e0145289. doi:10.1371/journal. pone. 0145289

Gildea, S. (2008). Explaining similarities between main clauses and nominalized phrases. Amerindia, 32, 57-75.

Hammarström, H. (2006). Rarities in numeral systems. In Paper presented at Rara \& Rarissima: Collecting and interpreting unusual characteristics of human languagesЛейпциг:

Hammarström, H., \& Güldemann, T. (2014). Quantifying geographical determinants of large-scale distributions of linguistic features. Language Dynamics and Change, 4(1), 87-115. doi:10.1163/22105832-00401002

Ingram, D. (1978). Typology and universals of personal pronouns. In J.H. Greenberg (Ed.), Universals of human language, vol. 3: Word structure (pp.213-247). Stanford, CA: Stanford University Press.

Kay, P. (2005). Commentary on Everett (2005). Current Antropology, 46(4), 636-637.

Kay, P., Berlin, B., Maffi, L., Merrifield, W.R., \& Cook, R. (2009). The world color survey. Stanford, CA: Center for the Study of Language and Information.

Kibrik, A.A. (1998). Nekotorye foneticheskie i grammaticheskie osobennosti russkogo dialekta derevni Ninilchik (Alyaska) [Some fonetic and grammatic characteristics of the Russian dialect of Ninilchik village (Alyaska)]. In V.F. Vydrin, \& A.A. Kibrik (Eds.), Iazyk, Afrika, Ful'be. Sbornik nauchnykh statei $v$ chest' AI Koval [Language. Africa. Fulbe. Paper collection in honor of AI Koval] (pp.36-52). Saint-Petersburg, Moscow: Evropeiskii dom. (In Russian).

Kibrik, A.A., \& Podlesskaya, V.I. (Eds.). (2009). Rasskazy o snovideniiakh: Korpusnoe issledovanie ustnogo russkogo diskursa. Moscow: LRC Publishers. (In Russian).

Kracke, W. (2009). Two ergativities and their cultural correlates. Revista Brasileira de Linguística Antropológica, 1(1), 13-25.

Krüsi, M., \& Krüsi, D. (1978). Phonology of Chiquitano. Work papers of the Summer Institute of Linguistics. Riberalta: Summer Institute of Linguistics.

Mann, W.C., \& Thompson, S.A. (1988). Rhetorical Structure Theory: Toward a functional theory of text organization. Text, 8(3), 243-281. doi:10.1515/text.1.1988.8.3.243

Mead, M. (1939). Native languages as fieldwork tools. American Anthropologist, 41(2), 189-205. doi:10.1525/ aa.1939.41.2.02a00010
Miranda, M.G. (2014). Morfologia e morfossintaxe da língua Krahô (família Jê, tronco Macro-Jê). Unpublished doctoral dissertation, Universidade de Brasília. (In Portuguese).

Moore, L.C. (2009). On communicative competence in the field. Language and Communication, 29(3), 244-253. doi:10.1016/j.langcom.2009.02.006

Mufwene, S. (1993). Investigating Gullah: Difficulties in ensuring "authenticity". In A.W. Glowka, \& D.M. Lance (Eds.) Language variation in North American English: Research and teaching (pp.178-190). New York, NY: Modern Language Association.

Munro, R., Ludwig, R., Sauerland, U., \& Fleck, D.W. (2012) Reported speech in Matses: Perspective persistence and evidential narratives. International Journal of American Linguistics, 78(1), 41-75. doi:10.1086/662637

Nevins, A., Pesetsky, D., \& Rodrigues, C. (2009). Pirahã exceptionality: A reassessment. Language, 85(2), 355-404. doi:10.1353/ $\underline{\text { lan. } 0.0107}$

Nevins, A., Pesetsky, D., \& Rodrigues, C. (2009). Evidence and argumentation: A reply to Everett (2009). Language, 85(3), 671-681. doi:10.1353/lan.0.0140

Newman, P., \& Ratliff, M. (2001). Introduction. In P. Newman, \& M. Ratliff (Eds.), Linguistic fieldwork (pp. 1-14). Cambridge: Cambridge University Press.

Oliveira, C.C.de. (2005). The language of the Apinaje people of Central Brazil. Unpublished doctoral dissertation, University of Oregon.

Pessoa, K.N. (2012). Análise fonética e fonológica da língua Krenak e abordagem preliminar de contos Botocudo. Unpublished doctoral dissertation, Universidade Estadual de Campinas. (In Portuguese). Retrieved from http:// repositorio.unicamp.br/bitstream/REPOSIP/270866/1/ Pessoa KatiaNepomuceno D.pdf.

Popjes, J., \& Popjes, J. (1986). Canela-Krahô. In D.C. Derbyshire, \& G.K. Pullum (Eds.), Handbook of Amazonian languages, Vol. 1. (pp. 128-199). Berlin: Mouton de Gruyter.

Ribeiro, M.A. (2008). Dicionário Djeoromitxí-Português. Registro da diveridade lingüística do povo Jabuti. Unpublished master's thesis, Fundação Universidade Federal de Rondônia, Campus de Guajará-Mirim. (In Portuguese). Retrieved from http://livros01.livrosgratis.com.br/cp084588.pdf.

Rice, K. (2012). Ethical Issues in Linguistic Fieldwork. In N. Thieberger (Ed.), The Oxford handbook of linguistic fieldwork (pp.407-429). Oxford; New York, NY: Oxford University Press.

Roberts, S., \& Winters, J. (2013). Linguistic diversity and traffic accidents: Lessons from statistical studies of cultural traits PLoS One, 8(8), e70902. doi:10.1371/journal.pone.0070902

Roeper, T., \& Snyder, W. (2005). Language learnability and the forms of recursion. In A.M. Di Sciullo (Ed.), Linguistik Aktuell/Linguistics Today (pp.155-169). Amsterdam: John Benjamins Publishing Company. doi:10.1075/la.75.10roe

Salles, R. (2015). Understanding recursion and looking for selfembedding in Pirahã. The case of possessive constructions. Unpublished master's thesis, PUC-Rio. doi:10.17771/ PUCRio.acad.26480

Sans, P. (2010). Éléments de sociolinguistique et de phonologie du bésiro (chiquitano). Langue en danger des basses terres de Bolivie. Unpublished master's thesis, Université Lumière Lyon 2. (In Spanish). Retrieved from http://www.ddl.cnrs.fr/ fulltext/Sans/Sans 2010 light.pdf.

Sans, P. (2013). Elementos de la gramática del Béstro: Sociolingüística - Fonología - Morfología - Textos. Con la colaboración de: Lucas Chorez Quiviquivi. San Antonio de Lomerío, Bolivia: Laboratoire Dynamique du Language. (In Spanish).

Sarvasy, H. (2015). Monolingual fieldwork in and beyond the classroom: the Logooli experience at UCLA. In Proceedings of CLS, Vol.51. (pp.471-484).

Sauerland, U. (2015). False speech reports in Pirahã: A comprehension experiment. To appear in Recursion and embedding in Brazilian languages and beyond. Retrieved from http:// ling.auf.net/lingbuzz/002850 
Seki, L. (2004). Aspectos da Morfossintaxe Krenak: Orações Independentes. Línguas Indígenas Americanas, 4(1), 129-146. (In Portuguese). Retrieved from https://periodicos.sbu. unicamp.br/ojs/index.php/liames/article/view/1431/1421.

Sheldon, S.N. (1988). Os sufixos verbais Mura-Pirahã. Série Lingüística, 9, 146-75. (In Portuguese).

Silva, T.C.A.de.(1986). Descrição fonética e análise de alguns processos fonológicos da língua Krenák. Unpublished master's thesis, Universidade Federal de Minas Gerais. (In Portuguese).
Sorokina, I.P., \& Volodin, A.P. (2014). Kategoriya lichnoi prinadlezhnosti v samodiiskikh yazykakh [Category of personal possessiveness in Samoyedic languages]. In S.A. Myznikov (Ed.), Voprosy uralistiki 2014. Nauchnyi al'manakh [Issues in Uralistics 2014. Paper collection] (pp.32-85). SaintPetersburg: NestorIstoriya. (In Russian). 